Nevada

Environmental

Restoration

Project

Post-Closure Inspection Report for the Tonopah Test Range, Nevada

For Calendar Year 2006

Controlled Copy No.:

Revision: 0

June 2007

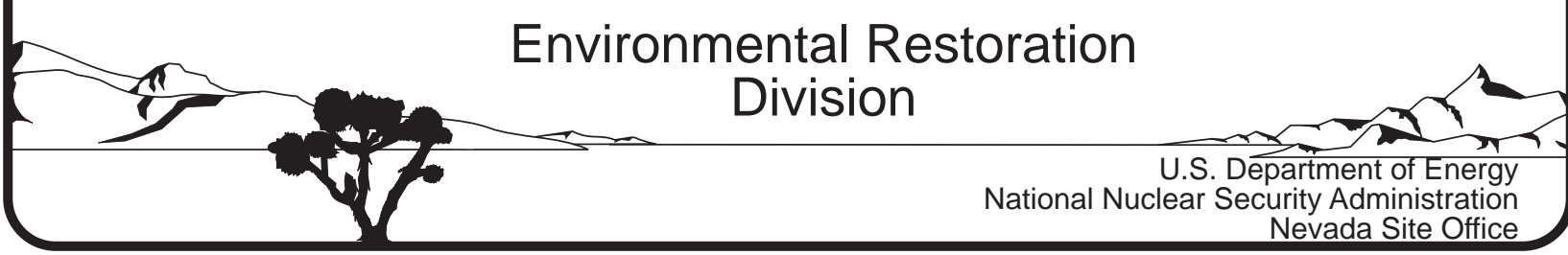




\section{DISCLAIMER}

Reference herein to any specific commercial product, process, or service by trade name, trademark, manufacturer, or otherwise, does not necessarily constitute or imply its endorsement, recommendation, or favoring by the U.S. Government or any agency thereof or its contractors or subcontractors.

This report has been reproduced directly from the best available copy.

Available for sale to the public from:

U.S. Department of Commerce

National Technical Information Service

5285 Port Royal Road

Springfield, VA 22161-0002

Telephone: (800) 553-6847

Fax: (703) 605-6900

E-mail: orders@ntis.gov

Online ordering: http://www.ntis.gov/ordering.htm

Available electronically at http://www.osti.gov/bridge.

Available for a processing fee to the U.S. Department of Energy and its contractors, in paper, from:

U.S. Department of Energy

Office of Scientific and Technical Information

P.O. Box 62

Oak Ridge, TN 37831-0062

Telephone: (865) 576-8401

Fax: (865) 576-5728

E-mail: reports@adonis.osti.gov 


\title{
POST-CLOSURE INSPECTION REPORT FOR THE TONOPAH TEST RANGE, NEVADA
}

\section{FOR CALENDAR YEAR 2006}

\author{
U.S. Department of Energy \\ National Nuclear Security Administration \\ Nevada Site Office \\ Las Vegas, Nevada
}

Controlled Copy No.

Revision: 0

June 2007 
THIS PAGE INTENTIONALLY LEFT BLANK 


\title{
POST-CLOSURE INSPECTION REPORT FOR THE TONOPAH TEST RANGE, NEVADA
}

\author{
FOR CALENDAR YEAR 2006
}

$\begin{array}{rlr}\text { Approved By: } & \text { SIGNATURE APPROVED } & \text { Date: } \underline{05 / 30 / 2007} \\ \text { Kevin J. Cabble, } & \text { Federal Sub-Project Director } \\ \text { Industrial Sites Sub-Project } & & \\ \text { Approved By: } & \text { SIGNATURE APPROVED } & \text { Date: } \underline{05 / 30 / 2007} \\ \text { Wilhelm R. Wilborn, } & \\ & \text { Acting Federal Project Director } \\ & \text { Environmental Restoration Project } & \end{array}$ 
THIS PAGE INTENTIONALLY LEFT BLANK 


\section{TABLE OF CONTENTS}

ACRONYMS AND ABBREVIATIONS …………............................................................ vii

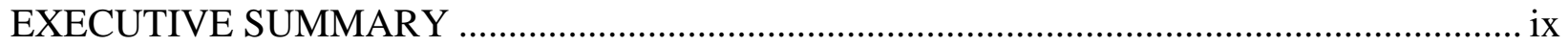

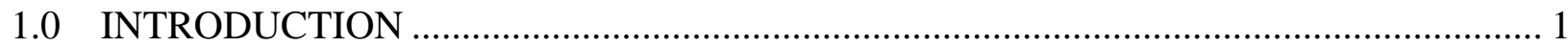

1.1 SCOPE AND OBJECTIVES ................................................................................... 1

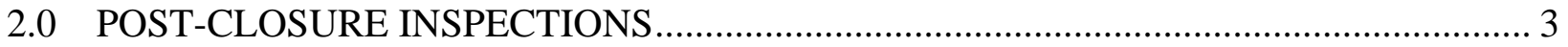

2.1 CAU 400: Bomblet PIT AND FIVE PoINTS LANDFILl (TTR) ……………………....... 3

2.1.1 Introduction........................................................................................... 3

2.1.2 CAU 400 Inspection Results ............................................................. 3

2.1.3 CAU 400 Maintenance and Repairs ............................................................... 4

2.1.4 CAU 400 Conclusions and Recommendations................................................. 4

2.2 CAU 404: RolLER COASTER LAGOONS AND TRENCH (TTR) ……………………...... 4

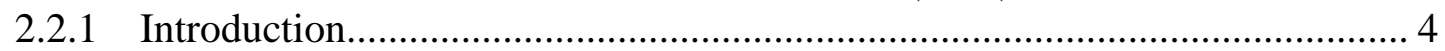

2.2.2 CAU 404 Inspection Results ...................................................................... 5

2.2.3 CAU 404 Maintenance and Repairs ………………....................................... 5

2.2.4 CAU 404 Conclusions and Recommendations.................................................. 5

2.3 CAU 407: RolLER COASTER RADSAFE AREA (TTR) …………………………........ 5

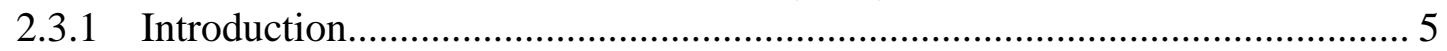

2.3.2 CAU 407 Inspection Results ...................................................................... 6

2.3.3 CAU 407 Maintenance and Repairs ............................................................... 6

2.3.4 CAU 407 Conclusions and Recommendations................................................. 6

2.4 CAU 423: AREA 3 Underground Discharge Point, BUILDING 0360 (TTR).......... 6

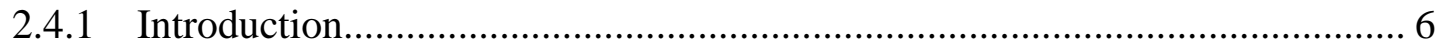

2.4.2 CAU 423 Inspection Results ................................................................... 6

2.4.3 CAU 423 Maintenance and Repairs ……………........................................... 7

2.4.4 CAU 423 Conclusions and Recommendations................................................ 7

2.5 CAU 424: AREA 3 LANDFILL COMPLEXES (TTR) …….............................................. 7

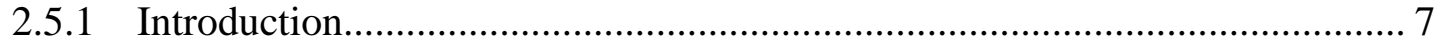

2.5.2 CAU 424 Inspection Results ................................................................... 7

2.5.3 CAU 424 Maintenance and Repairs ……………...................................... 10

2.5.4 CAU 424 Conclusions and Recommendations............................................... 10

2.6 CAU 426: CActus SPRING WASTE TRENChES (TTR) ............................................ 10

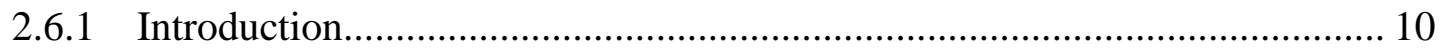

2.6.2 CAU 426 Inspection Results ............................................................... 10

2.6.3 CAU 426 Maintenance and Repairs .............................................................. 10

2.6.4 CAU 426 Conclusions and Recommendations................................................ 11

2.7 CAU 427: AREA 3 SePtiC WASTE SyStems 2, 6 (TTR).......................................... 11

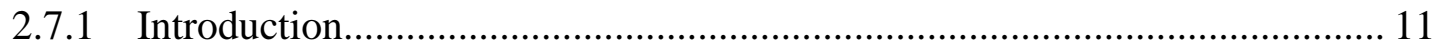

2.7.2 CAU 427 Inspection Results ..................................................................... 11

2.7.3 CAU 427 Maintenance and Repairs ............................................................ 11

2.7.4 CAU 427 Conclusions and Recommendations................................................. 11

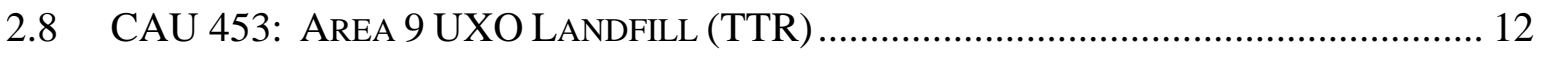

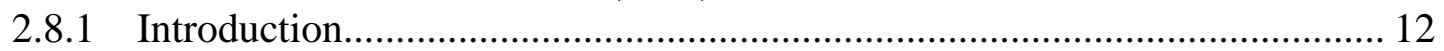




\section{TABLE OF CONTENTS (continued)}

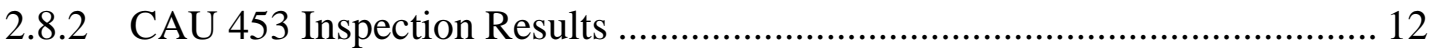

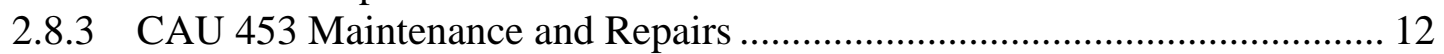

2.8.4 CAU 453 Conclusions and Recommendations......................................... 12

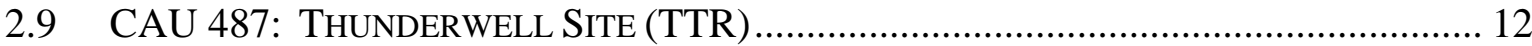

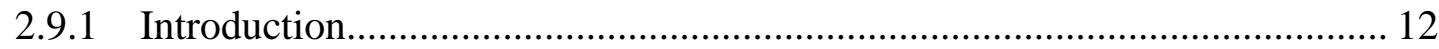

2.9.2 CAU 487 Inspection Results ................................................................ 13

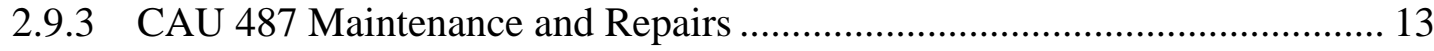

2.9.4 CAU 487 Conclusions and Recommendations........................................... 13

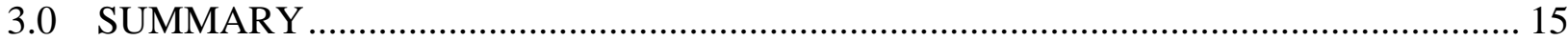

3.1 CAU 400: Bomblet Pit AND Five Points LANDFILL (TTR) ................................. 15

3.2 CAU 404: Roller COASTER LAGOONS AND TRENCH (TTR) ............................... 15

3.3 CAU 407: RolLER COASTER RADSAFE AREA (TTR) ........................................... 15

3.4 CAU 423: Area 3 Underground Discharge Point, Building 0360 (TTR)....... 15

3.5 CAU 424: AREA 3 LANDFILL COMPLEXES (TTR) ............................................... 15

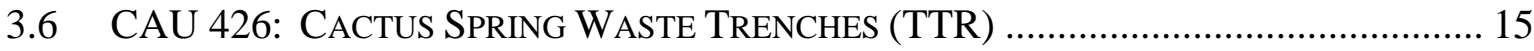

3.7 CAU 427: AREA 3 SEPTIC WASTE SySTEMS 2, 6 (TTR) .......................................... 16

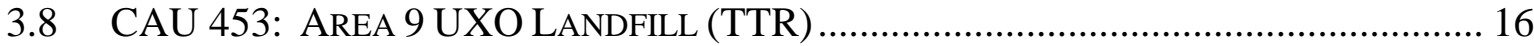

3.9 CAU 487: THUNDERWELL SITE (TTR) ......................................................... 16

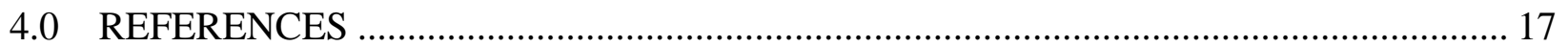

LIBRARY DISTRIBUTION LIST

\section{ATTACHMENTS}

AtTACHMENT A. FiguRES

AtTACHMEnt B. Post-Closure Inspection Plans

AtTachment C. Post-Closure InsPeCtion CheCKLISTS

ATTACHMENT D. FIELD NOTES

ATTACHMENT E. PHOTOGRAPHS

Attachment F. Post-Closure Vegetation Monitoring Report 


\section{ACRONYMS AND ABBREVIATIONS}

CADD

CAS

CAU

CR

$\mathrm{DOE} / \mathrm{NV}$

NDEP

NNSA

NNSA/NSO

ROTC

TTR
Corrective Action Decision Document

Corrective Action Site

Corrective Action Unit

Closure Report

U.S. Department of Energy, Nevada Operations Office

Nevada Division of Environmental Protection

U.S. Department of Energy, National Nuclear Security Administration

U.S. Department of Energy, National Nuclear Security Administration

Nevada Site Office

Record of Technical Change

Tonopah Test Range 
Post-Closure Inspection Report - TTR

Revision: 0

Date: June 2007

THIS PAGE INTENTIONALLY LEFT BLANK 


\section{EXECUTIVE SUMMARY}

This report provides the results of the semiannual post-closure inspections conducted at the closed Corrective Action Unit (CAU) sites located on the Tonopah Test Range (TTR), Nevada. This report covers calendar year 2006 and includes inspection and repair activities completed at the following nine CAUs :

- CAU 400: Bomblet Pit and Five Points Landfill (TTR)

- CAU 404: Roller Coaster Lagoons and Trench (TTR)

- CAU 407: Roller Coaster RadSafe Area (TTR)

- CAU 423: Area 3 Underground Discharge Point, Building 0360 (TTR)

- CAU 424: Area 3 Landfill Complexes (TTR)

- CAU 426: Cactus Spring Waste Trenches (TTR)

- CAU 427: Area 3 Septic Waste Systems 2, 6 (TTR)

- CAU 453: Area 9 UXO Landfill (TTR)

- CAU 487: Thunderwell Site (TTR)

Post-closure inspections were conducted on May 9, 2006, May 31, 2006, and November 15, 2006. All inspections were conducted according to the post-closure plans in the approved Closure Reports. The post-closure inspection plan for each CAU is included in Attachment B, with the exception of CAU 400 . CAU 400 does not require post-closure inspections, but inspections of the vegetation and fencing are conducted as a best management practice. The inspection checklists for each site inspection are included in Attachment C, the field notes are included in Attachment D, and the site photographs are included in Attachment E. Vegetation monitoring of CAU 400, CAU 404, CAU 407, and CAU 426 was performed in June 2006, and the vegetation monitoring report is included in Attachment F.

Maintenance and/or repairs were performed at CAU 400, CAU 407, CAU 426, CAU 453, and CAU 487 in 2006. During the May inspection of CAU 400, it was identified that the east and west sections of chickenwire fencing beyond the standard fencing were damaged; they were repaired in June 2006. Also in June 2006, the southeast corner fence post and one warning sign at CAU 407 were reinforced and reattached, the perimeter fencing adjacent to the gate at CAU 426 was tightened, and large animal burrows observed at CAU 453 were backfilled. Cracking observed in three monuments at CAU 487 was repaired using sealant during the May 9, 2006, inspection.

At this time, the TTR post-closure site inspections should continue as scheduled. Any potential problem areas previously identified (e.g., areas of erosion, subsidence) should be monitored closely, and periodic vegetation surveys of the vegetated covers should continue. 
Post-Closure Inspection Report - TTR

Revision: 0

Date: June 2007

THIS PAGE INTENTIONALLY LEFT BLANK 


\subsection{INTRODUCTION}

\subsection{SCOPE AND OBJEctives}

This post-closure inspection report includes the results of inspections, maintenance and repair activities, and conclusions and recommendations for calendar year 2006 for nine Corrective Action Units (CAUs) located on the Tonopah Test Range (TTR), Nevada. The locations of the CAUs are shown in Figure 1 of Attachment A. The CAUs and Corrective Action Sites (CASs) covered in this report include the following:

- CAU 400: Bomblet Pit and Five Points Landfill (TTR)

- CAS TA-19-001-05PT: Ordnance Disposal Pit

- CAS TA-55-001-TAB2: Ordnance Disposal Pit

- CAU 404: Roller Coaster Lagoons and Trench (TTR)

- CAS TA-03-001-TARC: Roller Coaster Lagoons

- CAS TA-21-001-TARC: Roller Coaster N. Disposal Trench

- CAU 407: Roller Coaster RadSafe Area (TTR)

- CAS TA-23-001-TARC: Roller Coaster RadSafe Area

- CAU 423: Area 3 Underground Discharge Point, Building 0360 (TTR)

- CAS 03-02-002-0308: Underground Discharge Point

- CAU 424: Area 3 Landfill Complexes (TTR)

- CAS 03-08-001-A301: Landfill Cell A3-1

- CAS 03-08-002-A302: Landfill Cell A3-2

- CAS 03-08-002-A303: Landfill Cell A3-3

- CAS 03-08-002-A304: Landfill Cell A3-4

- CAS 03-08-002-A305: Landfill Cell A3-5

- CAS 03-08-002-A306: Landfill Cell A3-6

- CAS 03-08-002-A308: Landfill Cell A3-8

- CAU 426: Cactus Spring Waste Trenches (TTR)

- CAS RG-08-001-RGCS: Waste Trenches

- CAU 427: Area 3 Septic Waste Systems 2, 6 (TTR)

- CAS 03-05-002-SW02: Septic Waste System

- CAS 03-05-002-SW06: Septic Waste System

- CAU 453: Area 9 UXO Landfill (TTR)

- CAS 09-55-001-0952: Area 9 Landfill

- CAU 487: Thunderwell Site (TTR)

- CAS RG-26-001-RGRV: Thunderwell Site 
Post-closure inspections are conducted on a semiannual basis (twice per calendar year) and consist of the following activities to evaluate and document the condition of the closed units. CAU-specific inspection requirements are included in Attachment B.

- Site inspections and photographs to verify site conditions and note variances from previous inspections

- Inspection of fencing, signs, monuments, and/or markers to determine if repairs and/or maintenance are needed

- Inspection of soil covers for indications of subsidence, erosion, unauthorized use, etc.

- Vegetation survey to quantify the condition of vegetative covers

- Subsidence survey to indicate any cover subsidence

- Preparation and submittal of an annual report

This Post-Closure Inspection Report includes the following sections:

- Section 1.0 - Introduction

- $\quad$ Section 2.0 - Post-Closure Inspections

- Section 3.0 - Summary

- $\quad$ Section 4.0 - References

- Attachment A - Figures

- Attachment B - Post-Closure Inspection Plans

- Attachment C - Post-Closure Inspection Checklists

- Attachment D - Field Notes

- Attachment E - Photographs

- Attachment F - Post-Closure Vegetation Monitoring Report

- Library Distribution List 


\subsection{POST-CLOSURE INSPECTIONS}

Post-closure site inspections of TTR CAUs for the annual period January 2006 through December 2006 were conducted on May 9, 2006, May 31, 2006, and November 15, 2006. Copies of post-closure inspection plans as previously published in the applicable Closure Report (CR) are included in Attachment B. Copies of the site inspection checklists are included in Attachment C, field notes are included in Attachment D, and site photographs are included in Attachment E.

\subsection{CAU 400: Bomblet Pit AND Five Points Landfill (TTR)}

\subsubsection{Introduction}

There are no specific post-closure requirements in the CR for CAU 400, Bomblet Pit and Five Points Landfill (TTR); however, when the sites were vegetated in 1997 under the Tonopah Test Range Closure Sites Revegetation Plan (U.S. Department of Energy Nevada Operations Office [DOE/NV], 1997), fencing was installed at the Bomblet Pit (CAS TA-55-001-TAB2, Ordnance Disposal Pit) and the Five Points Landfill (CAS TA-19-001-05PT, Ordnance Disposal Pit). As stated in Section 3.5.4 of the revegetation plan (DOE/NV, 1997), fencing is required at both CASs for a minimum of 5 years in order to give the plants sufficient time to become established. Therefore, inspections are conducted at CAU 400 to document vegetation growth and inspect the integrity of the fences. Removal of site fencing may be proposed in the future, once vegetation on the covers is well established. Vegetation monitoring of CAU 400 was conducted in June 2006, and the results are included in Attachment F.

\subsubsection{CAU 400 Inspection Results}

\subsubsection{First Semiannual Inspection}

\section{Bomblet Pit (CAS TA-55-001-TAB2, Ordnance Disposal Pit)}

The Bomblet Pit is presented in Figure 2 of Attachment A. The first inspection was conducted on May 31, 2006. The cover vegetation was healthy, well established, and similar to the surrounding area outside the fence. The fence, site signs, and cover were in good condition, but the east and west sections of chickenwire fencing beyond the standard fencing were damaged, necessitating repair. Additionally, a bomblet with a suspected fuse was discovered at the conclusion of the inspection. The area was marked with orange flagging, and a Westinghouse safety representative was notified of the bomblet location.

\section{Five Points Landfill (CAS TA-19-001-05PT, Ordnance Disposal Pit)}

The Five Points Landfill is presented in Figure 3 of Attachment A. The first inspection was conducted on May 31, 2006. The inspection indicated some minor animal burrows within and outside of the fence at the northeast corner of the site. All signs and fencing were in good condition. The cover vegetation appeared normal, with the continuance of nominal growth after reseeding in 2004. 


\subsubsection{Second Semi-Annual Inspection}

\section{Bomblet Pit (CAS TA-55-001-TAB2, Ordnance Disposal Pit)}

The second inspection was conducted on November 15, 2006. Repairs made to the fencing in June 2006, as well as the rest of the fencing, signs, and vegetated cover, were in good condition. No other site issues were noted, and no repairs were required as a result of the inspection.

Five Points Landfill (CAS TA-19-001-05PT, Ordnance Disposal Pit)

The second inspection was conducted on November 15, 2006. All signs and fencing were in good condition. Evidence of animal burrows was observed near the front fence. However, due to apparent flooding in the area, no living vegetation remained in the low-lying areas of the cover. (See Attachment E, Photographs 5 and 6.) An ecological specialist will evaluate the site in 2007 for new vegetation growth, and options will be considered depending upon the site conditions at that time. Because of the loss of vegetation, the recommendation of the U.S. Department of Energy, National Nuclear Security Administration Nevada Site Office (NNSA/NSO) and Nevada Division of Environmental Protection (NDEP) to remove the fence following the 2006 inspection, contingent upon healthy vegetation, was not implemented. No maintenance or repairs were recommended as a result of this site inspection.

\subsubsection{CAU 400 Maintenance and Repairs}

Repairs were made to the chicken wire fence at the CAU 400 Bomblet Pit, CAS TA-55-001-TAB2, in June 2006. No repairs were required at the Five Points Landfill.

\subsubsection{CAU 400 Conclusions and Recommendations}

While the Bomblet Pit site was in excellent condition, the Five Points Landfill experienced a significant loss of vegetation. As stated in the revegetation plan (DOE/NV, 1997), the sites are to be fenced for a minimum of 5 years in order to give the vegetation sufficient time to become established. Based on the results of the 2006 inspections and the Post-Closure Vegetation Monitoring Report (Attachment F), it has been determined that the vegetation is not currently sufficiently established to remove the fences. Until it is determined that the vegetation has matured to the same extent as the surrounding undisturbed areas, both sites will remain fenced and semiannual site inspections will continue.

\subsection{CAU 404: ROLLER COASTER LAgOONS AND TRENCH (TTR)}

\subsubsection{Introduction}

CAU 404, Roller Coaster Lagoons and Trench (TTR), consists of two CASs

(CAS TA-03-001-TARC, Roller Coaster Lagoons; and CAS TA-21-001-TARC, Roller Coaster N. Disposal Trench). Post-closure requirements are described in the CR for CAU 404 (DOE/NV, 1998a), which was approved by NDEP on May 18, 1999.

Site inspections were conducted on May 9, 2006, and November 15, 2006. A diagram showing the site location and configuration is presented as Figure 4 of Attachment A. The site inspections were conducted according to the CAU 404 post-closure inspection plan (Attachment B). In addition to site inspections, vegetation monitoring of the site was conducted in June 2006, and the results are included in Attachment F. 


\subsubsection{CAU 404 Inspection Results}

\subsubsection{First Semiannual Inspection}

The first inspection was conducted on May 9, 2006. This site was in good condition. No damage was noted to the fencing, signs, or cover. The vegetation was healthy and well established. Some small animal burrows were noted outside of the site fencing, but no maintenance or repairs were needed.

\subsubsection{Second Semiannual Inspection}

The second inspection was completed on November 15, 2006. The unit was in good condition, and no animal burrows were observed during the site inspection. The fence was in good condition, and all warning signs were intact and legible. No erosion, subsidence, or cracking of the cover was observed and the cover vegetation was healthy. No maintenance or repairs were recommended as a result of this inspection.

\subsubsection{CAU 404 Maintenance and Repairs}

No maintenance or repairs were required at CAU 404 during 2006.

\subsubsection{CAU 404 Conclusions and Recommendations}

The cover, fence, posted warning signs, and gates were all in good condition. Overall plant cover has met revegetation standards. Consequently, removal of the fence surrounding the cover may be considered during the next reporting period, and site inspections should continue as scheduled.

\subsection{CAU 407: ROLlER CoASTER RADSAFE AREA (TTR)}

\subsubsection{Introduction}

CAU 407, Roller Coaster RadSafe Area (TTR), consists of one CAS (CAS TA-23-001-TARC, Roller Coaster RadSafe Area). The post-closure requirements for CAU 407 are described in the CR (DOE/NV, 2001a). Revision 1 of the CR was approved by the NDEP on February 22, 2002. Section 5.2 of the CR calls for site inspections to be conducted within the first 6 months following completion of cover construction. After the first 6 months, site inspections are to be conducted twice yearly for the next 2 years. Previous inspections have noted erosion rills on the cover margins, and subsequent maintenance was completed to repair the rills and help prevent future erosion; consequently, inspections will continue until the site stabilizes.

Site inspections were conducted on May 9, 2006, and November 15, 2006. A diagram showing the site location and configuration is presented in Figure 5 of Attachment A. The site inspections were conducted according to the CAU 407 post-closure inspection plan (Attachment B). In addition to site inspections, vegetation monitoring of the site was conducted in June 2006, and the results are included in Attachment F. 


\subsubsection{CAU 407 Inspection Results}

\subsubsection{First Semiannual Inspection}

The first inspection was conducted on May 9, 2006. The inspection indicated the cover was in good condition, and local grasses were becoming established on the cover. Many small animal burrows were present along the southern edge of the fencing, and options for mitigating burrowing were considered. Additionally, the southeast corner fence post required reinforcing, and one warning sign required reattachment. Otherwise, the fence and warning signs were intact and in good condition.

\subsubsection{Second Semiannual Inspection}

The second inspection was conducted on November 15, 2006. Repairs made to the fencing and signs in June 2006 were in good condition. No animal burrows were observed inside the fence, and no erosion cracks or subsidence of the cover was observed during the inspection. The fencing, signage, and cover were in good condition. No maintenance or repairs were recommended.

\subsubsection{CAU 407 Maintenance and Repairs}

A loose radiological warning sign was reattached, and the southeast corner fence post was reinforced in June 2006.

\subsubsection{CAU 407 Conclusions and Recommendations}

This site was in good condition. Vegetation on the cover had decreased by nearly 50 percent during the 2005-2006 reporting period. The site inspections should continue as scheduled, and the health of the vegetation and integrity of the cover should continue to be monitored until the site has stabilized.

\subsection{CAU 423: Area 3 Underground Discharge Point, Building 0360 (TTR)}

\subsubsection{Introduction}

CAU 423, Area 3 Underground Discharge Point, Building 0360 (TTR), consists of one CAS (CAS 03-02-002-0308, Underground Discharge Point). CAU 423 was closed in place, with one warning sign and one at-grade monument installed, as detailed in the CR (DOE/NV, 1999a). The CR did not originally require post-closure inspections. A Record of Technical Change (ROTC) to the CR (NNSA/NSO, 2005), specifying the post-closure inspection requirements, was approved by NDEP on June 6, 2005 (Attachment B). Site inspections were conducted on May 9, 2006, and November 15, 2006. A diagram showing the site location and configuration is presented in Figure 6 of Attachment A.

\subsubsection{CAU 423 Inspection Results}

\subsubsection{First Semiannual Inspection}

The first inspection was conducted on May 9, 2006. The warning sign and at-grade monument were in excellent condition, and no site issues were observed. 


\subsubsection{Second Semiannual Inspection}

The second inspection was conducted on November 15, 2006. The site was in excellent condition, and the warning sign and at-grade monument were in good condition. As per direction from the U.S. Department of Energy, National Nuclear Security Administration (NNSA), a waste oil line running to an underground discharge point will be removed or closed in place as a best management practice. Closure activities are scheduled for 2007.

\subsubsection{CAU 423 Maintenance and Repairs}

No maintenance or repairs at CAU 423 were required in 2006.

\subsubsection{CAU 423 Conclusions and Recommendations}

The warning sign and at-grade monument were in good condition. The site inspections should continue as scheduled.

\subsection{CAU 424: Area 3 Landfill CompleXes (TTR)}

\subsubsection{Introduction}

CAU 424, Area 3 Landfill Complexes (TTR), consists of eight CASs. Seven landfill cells (CAS 03-08-001-A301, Landfill Cell A3-1; CAS 03-08-002-A302, Landfill Cell A3-2; CAS 03-08-002-A303, Landfill Cell A3-3; CAS 03-08-002-A304, Landfill Cell A3-4; CAS 03-08-002-A305, Landfill Cell A3-5; CAS 03-08-002-A306, Landfill Cell A3-6; and CAS 03-08-002-A308, Landfill Cell A3-8) were closed with soil covers and require post-closure inspections. CAS 03-08-002-A307, Landfill Cell A3-7, was not used as a landfill site and was closed without taking any corrective action. CAU 424 closure activities included removing small volumes of soil containing petroleum hydrocarbons, repairing cell covers that were cracked and/or had subsided, and installing above-grade and at-grade monuments to mark the corners of the landfill cells. Post-closure requirements for CAU 424 are detailed in the CR, which was approved by NDEP in July 1999 (DOE/NV, 1999b).

Site inspections of the seven CASs were conducted on May 9, 2006, and November 15, 2006. The site inspections were conducted according to the CAU 424 post-closure inspection plan (Attachment B). A diagram showing the landfill locations is presented in Figure 7 of Attachment A.

\subsubsection{CAU 424 Inspection Results}

\subsubsection{First Semiannual Inspection}

The first site inspection was conducted on May 9, 2006.

Landfill Cell A3-1 (CAS 03-08-001-A301)

Landfill Cell A3-1 is located at the north end of CAU 424 and is the largest of the landfill cells. The cover and seven above-grade concrete monuments that demarcate the landfill cell were examined. All signs, survey markers, and monuments were in good condition. Vegetation is established throughout the site and no cracking, erosion, or subsidence of the cover was observed, though the surface did show the effects of weathering in some places. 
Landfill Cell A3-2 is located due south of Landfill Cell A3-1. The overall condition of the unit was good. All four above-grade monuments and the landfill cover were examined and found to be in good condition. All signs and brass survey markers were legible and intact. No signs of erosion, subsidence, or evidence of unauthorized use were observed, though the surface did show the effects of weathering in some places.

\section{Landfill Cell A3-3 (CAS 03-08-002-A303)}

Landfill Cell A3-3 straddles the western fence of the TTR Area 3 Compound, with the portion of the landfill outside the fence marked by three above-grade monuments, and the portion inside the fence marked by three at-grade monuments. The overall condition of the site was good. All six monuments were located and inspected. All monuments, brass survey markers, and warning signs were in good condition. No subsidence, cracking, or erosion was observed. Sparse vegetation was present near the above-grade monuments, but none was present near the at-grade monuments. No issues or concerns were observed for this site.

Landfill Cell A3-4 (CAS 03-08-002-A304)

Landfill Cell A3-4 is located south of Dykes Drive at the south end of the CAU. The overall condition of the site was good, and vegetation is established throughout the site. Five above-grade monuments and one at-grade brass survey marker were located and inspected. All monuments, the brass survey marker, and warning signs were in good condition. No issues or concern were raised as a result of this inspection.

Landfill Cell A3-5 (CAS 03-08-002-A305)

Landfill Cell A3-5 is located west of Moody Avenue inside a fenced area in Area 10 south of the Air Force First-Aid Station. All four above-grade monuments and attached warning signs and brass survey markers were located and found to be in excellent condition. No evidence of subsidence, cracking, or erosion was observed, and sparse vegetation is present. The overall condition of the site is good.

\section{Landfill Cell A3-6 (CAS 03-08-002-A306)}

Landfill Cell A3-6 is located immediately west and outside of the fence of the TTR Area 3 Compound. All four above-grade monuments and attached warning signs and brass survey markers were located and found to be in good condition. The overall condition of the landfill cover was good. No evidence of subsidence, cracking, or erosion was observed, and there were no issues or concerns with this site.

\section{Landfill Cell A3-8 (CAS 03-08-002-A308)}

Landfill Cell A3-8 is located southwest of the Area 3 Compound in the box car storage yard. Three of the four at-grade brass markers were located and determined to be in good condition. The southwest corner monument was not located due to its location in a posted radioactive materials area and the presence of surface debris. There was no indication that the debris was impacting the condition of the monument. The monument will be examined in future inspections when the surface debris is removed. No erosion, subsidence, or evidence of unauthorized use was observed at the site. The overall condition of the cover was good. 


\subsubsection{Second Semi-Annual Inspection}

The second inspection was conducted on November 15, 2006.

Landfill Cell A3-1 (CAS 03-08-001-A301)

All signs and survey markers were intact and legible. The seven above-grade monuments were in good condition. No cracking, erosion, or evidence of unauthorized use of the cover was observed. The overall condition of the site was good. No maintenance or repairs were recommended.

\section{Landfill Cell A3-2 (CAS 03-08-002-A302)}

The four above-grade monuments were located and found to be in good condition. The signs and brass survey markers were also in good condition. Vegetation was widely dispersed on the cover. The overall condition of the unit was good. No maintenance or repairs were recommended.

\section{Landfill Cell A3-3 (CAS 03-08-002-A303)}

The three above-grade monuments and three at-grade monuments were located and inspected. All monuments, brass survey markers, and signs were in good condition. No subsidence or erosion was observed. No issues or concerns were observed for this site, and no maintenance or repairs were recommended.

\section{Landfill Cell A3-4 (CAS 03-08-002-A304)}

The five above-grade monuments and one at-grade brass survey marker were located and inspected. All monuments, the brass survey marker, and warning signs were in good condition. The cover showed no erosion, subsidence, or evidence of unauthorized use, and the vegetation was healthy and well established. No maintenance or repairs were required.

\section{Landfill Cell A3-5 (CAS 03-08-002-A305)}

The four above-grade monuments were located and inspected. The monuments, attached warning signs, and survey markers were in good condition. The vegetation growing on the cover was healthy. No evidence of subsidence, cracking, or erosion was observed. The overall condition of the landfill cover was good. No maintenance or repairs were required.

\section{Landfill Cell A3-6 (CAS 03-08-002-A306)}

The four above-grade monuments were located and inspected. The monuments and survey markers were in good condition. The warning signs were intact and legible. No evidence of subsidence, cracking, or erosion was observed. The overall condition of the site was good. No maintenance or repairs were required.

\section{Landfill Cell A3-8 (CAS 03-08-002-A308)}

Three of the four at-grade monuments were located and found to be in good condition. The southwest corner monument is located in a posted and fenced radioactive materials area where it cannot be visually inspected. The corner monument is also covered by debris, but does not appear to be impacted by the debris, and there is no sign of ground disturbance. No erosion, 
subsidence, or cracking was observed. The overall condition of the site was good. No maintenance or repairs were required.

\subsubsection{CAU 424 Maintenance and Repairs}

No maintenance or repairs at CAU 424 were required in 2006.

\subsubsection{CAU 424 Conclusions and Recommendations}

All seven CASs in CAU 424 are in good condition. The site inspections should continue as scheduled to monitor the landfill soil covers, markers, and warning signs.

\subsection{CAU 426: CActus SPRing WASTE Trenches (TTR)}

\subsubsection{Introduction}

CAU 426, Cactus Spring Waste Trenches (TTR), consists of one CAS (CAS RG-08-001-RGCS, Waste Trenches). The post-closure requirements are described in the CR for CAU 426 (DOE/NV, 1998b), which was approved by NDEP on May 13, 1999.

Site inspections were conducted on May 9, 2006, and November 15, 2006. A diagram showing the site location and configuration is presented in Figure 8 of Attachment A. The site inspections were conducted according to the CAU 426 post-closure inspection plan (Attachment B). In addition to site inspections, vegetation monitoring of the site was conducted in June 2006, and the results are included in Attachment F.

\subsubsection{CAU 426 Inspection Results}

\subsubsection{First Semiannual Inspection}

The first inspection was conducted on May 9, 2006. The fence perimeter was walked, and the site was found to be in excellent condition. While some tightening to the perimeter fencing was advised, there was no damage to the perimeter fence or signs, which were intact and legible. No erosion, subsidence, or evidence of unauthorized use was observed. Vegetation was well established and healthy throughout the site. No site maintenance or repairs are needed; however, it was recommended to tighten the fence as a best management practice.

\subsubsection{Second Semiannual Inspection}

The second inspection was conducted on November 15, 2006. The overall condition of the unit was good. The fence was in excellent condition. The fence had been tightened in June 2006, as advised during the first semiannual inspection, and the wire mesh along the base of the fence was intact. Several small animal burrows were noted around the fence, but it was determined that they did not affect the integrity of the unit. The signs were legible and in good condition. The vegetation was healthy and has stabilized the soil cover. No subsidence, cracking, or evidence of unauthorized use was observed. No maintenance or repairs were recommended.

\subsubsection{CAU 426 Maintenance and Repairs}

The perimeter fencing adjacent to the gate at CAU 426 was tightened in June 2006. No additional maintenance or repairs were performed during 2006. 


\subsubsection{CAU 426 Conclusions and Recommendations}

The cover, fence, and posted warning signs were all in excellent condition. Plant growth on the cover exceeds revegetation standards, and removal of the cover fence may be considered during the next reporting period. The site inspections should continue as scheduled.

\subsection{CAU 427: AREA 3 SePtic WASTe Systems 2, 6 (TTR)}

\subsubsection{Introduction}

CAU 427, Area 3 Septic Waste Systems 2, 6 (TTR), consists of two CASs

(CAS 03-05-002-SW02, Septic Waste System; and CAS 03-05-002-SW06, Septic Waste

System). The closed leachfields are located in the TTR Area 3 compound in a high-traffic area.

For this reason, the leachfield corners are marked by subsurface metal markers each covered with red cinder rock to the ground surface. The red rock aids in visually locating the markers during site inspections. Post-closure requirements for CAU 427 are detailed in the CR for CAU 427 (DOE/NV, 1999c), which was approved by NDEP on August 27, 1999.

Site inspections were conducted on May 9, 2006, and November 15, 2006. A diagram showing the site location and configuration is presented in Figure 9 of Attachment A. The site inspections were conducted according to the CAU 427 post-closure inspection plan (Attachment B).

\subsubsection{CAU 427 Inspection Results}

\subsubsection{First Semiannual Inspection}

The first inspection was conducted on May 9, 2006. All 21 subsurface metal markers were located at the corners of Leachfield A (four markers), Leachfield B (four markers), Abandoned Leachfield (four markers), Pre-1965 Leachfield (four markers), and Septic Tank 33-5 (five markers). The five warning signs were intact, in place, and legible. The site was observed to be in excellent condition, and no maintenance or repairs were recommended.

\subsubsection{Second Semiannual Inspection}

The second inspection was conducted on November 15, 2006. All 21 subsurface metal markers were located at the corners of Leachfield A (four markers), Leachfield B (four markers), Abandoned Leachfield (four markers), Pre-1965 Leachfield (four markers), and Septic Tank 33-5 (five markers). The five warning signs were located and found to be in good condition. No vegetation was present, and no evidence of subsidence, erosion, or intrusive activities into the use restricted areas was noted. The overall condition of the site was excellent. No maintenance or repairs were recommended.

\subsubsection{CAU 427 Maintenance and Repairs}

No maintenance or repairs at CAU 427 were required in 2006.

\subsubsection{CAU 427 Conclusions and Recommendations}

Overall the site was in excellent condition, and site inspections should continue as scheduled. The use of red rock to delineate each use-restriction marker was very effective, and no issues were associated with this site. 


\subsection{CAU 453: AREA 9 UXO LANDFILl (TTR)}

\subsubsection{Introduction}

CAU 453, Area 9 UXO Landfill (TTR), consists of one CAS (CAS 09-55-001-0952, Area 9 Landfill). Post-closure requirements for CAU 453 are described in the CR for CAU 453 (DOE/NV, 1999d), which was approved by NDEP on September 10, 1999.

Site inspections were conducted on May 31, 2006, and November 15, 2006. A diagram showing the site location and configuration is presented in Figure 10 of Attachment A. The site inspections were conducted according to the CAU 453 post-closure inspection plan (Attachment B).

\subsubsection{CAU 453 Inspection Results}

\subsubsection{First Semiannual Inspection}

The first inspection was conducted on May 31, 2006. The fence, signs, 16 above-ground monuments, and covers were all in excellent condition. However, several large animal burrows were noted during the inspection which required follow-up action.

\subsubsection{Second Semiannual Inspection}

The second inspection was conducted on November 15, 2006. The fence, signs, and 16 above-grade monuments were in good condition. Small burrows were observed but did not impact the integrity of the cover or necessitate any follow-up action.

\subsubsection{CAU 453 Maintenance and Repairs}

Large animal burrows observed during the initial CAU 453 inspection were backfilled in June 2006.

\subsubsection{CAU 453 Conclusions and Recommendations}

The fence, posted warning signs, and monuments are all in good condition. The site inspections should continue as scheduled.

\subsection{CAU 487: THUNDERWELL SITE (TTR)}

\subsubsection{Introduction}

CAU 487, Thunderwell Site (TTR), consists of one CAS (CAS RG-26-001-RGRV, Thunderwell Site). The Corrective Action Decision Document (CADD)/CR was approved by NDEP on December 17, 2001 (DOE/NV, 2001b). Buried waste and debris were present at the site but no contamination was found. Use restrictions were implemented at the site as explained in the CADD/CR, but no post-closure inspections were proposed. Two separate use restrictions were implemented to address areas associated with subsurface geophysical anomalies (anomalies A-8 and A-17). Concrete monuments were installed at both locations of buried waste. A ROTC to modify the CADD/CR to include post-closure inspections and use restriction information was approved by NDEP on July 30, 2004 (NNSA/NSO, 2004). 
Site inspections were conducted on May 9, 2006, and November 15, 2006. A diagram showing the site location and configuration is presented in Figure 11 of Attachment A.

\subsubsection{CAU 487 Inspection Results}

\subsubsection{First Semiannual Inspection}

The first inspection was conducted on May 9, 2006. All warning signs were in place, intact, and legible. At anomaly A-8, one monument showed evidence of cracking and was repaired using sealant. At anomaly A-17, two monuments showed evidence of cracking and were repaired with sealant.

\subsubsection{Second Semiannual Inspection}

The second inspection was conducted on November 15, 2006. All monuments were observed to be in good condition, and warning signs were in place and legible. No site issues were observed during this inspection. No maintenance or repairs were recommended.

\subsubsection{CAU 487 Maintenance and Repairs}

During the May 9, 2006, inspection, cracking observed in three monuments was repaired using sealant.

\subsubsection{CAU 487 Conclusions and Recommendations}

The site was observed to be in excellent condition in 2006, and site inspections should continue as scheduled. 
Post-Closure Inspection Report - TTR

Revision: 0

Date: June 2007

THIS PAGE INTENTIONALLY LEFT BLANK 


\subsection{SUMMARY}

\subsection{CAU 400: Bomblet Pit ANd Five Points Landfill (TTR)}

Site inspections at CAS TA-55-001-TAB2, Ordnance Disposal Pit (Bomblet Pit), indicated that the site is in excellent condition, while site inspections at CAS TA-19-001-05PT, Ordnance Disposal Pit (Five Points Landfill), indicated a dramatic loss of vegetation due to apparent flooding. Aside from the chicken wire fence, all fencing, signs, and vegetation are in good condition. Maintenance was conducted on the chicken wire fence at the Bomblet Pit site in June 2006. Site inspections should continue as scheduled, and an ecological specialist will evaluate vegetation conditions during 2007. The NNSA and NDEP recommendation for removing fencing after the 2006 inspections if the vegetation had matured to the same extent as the surrounding areas was not implemented.

\subsection{CAU 404: ROLLER COASTER LAgOONS AND TRENCH (TTR)}

Both site inspections indicated that the site was in good condition, and there was no damage noted to the fencing, signs, or cover. No animal burrowing was noted, and no maintenance or repairs were needed. The site was in good condition, and site inspections should continue as scheduled.

\subsection{CAU 407: ROLlER COASTER RADSAFE AREA (TTR)}

Site inspections indicated that the cover and warning signs were in good condition, and local grasses were becoming established. Small animal burrows were observed outside the fence but do not affect the integrity of the unit. Repairs to a fence post and a warning sign were made in June 2006. The site was in good condition, and site inspections should continue as scheduled.

\subsection{CAU 423: Area 3 Underground Discharge Point, Building 0360 (TTR)}

Site inspections indicated that the unit was in good condition. The warning sign and at-grade monument remained in good condition. No maintenance or repairs at CAU 423 were necessary in 2006. The removal of the oil line is scheduled for 2007. The site was in good condition, and site inspections should continue as scheduled.

\subsection{CAU 424: AREA 3 LANDFill COMPLEXES (TTR)}

Site inspections indicated that all signs and survey markers were in good condition. No subsidence, cracking, or evidence of unauthorized use of the cover was observed. All monuments were located and found to be in good condition. No repairs were necessary during 2006. The site is in excellent condition, and inspections should continue as scheduled.

\subsection{CAU 426: CACTUS SPRING WASTE TRENCHES (TTR)}

The site inspections indicated that the site was in good condition. All signs were intact, in place, and legible, and the fence and cover were in good condition. As a best management practice, the

fence was tightened in June 2006. Some small animal burrows were noted near to the fence, but 
do not affect the integrity of the unit. The site was in good condition, and site inspections should continue as scheduled.

\subsection{CAU 427: Area 3 SePtic WAste Systems 2, 6 (TTR)}

Site inspections at CAU 427 revealed that all warning signs and markers were intact and legible. The use of red rocks to delineate marker locations was effective. Overall, the site was in good condition, and site inspections should continue as scheduled.

\subsection{CAU 453: AREA 9 UXO LANDFILL (TTR)}

Site inspections indicated that the fence, signs, and monuments were in good condition. During the first site inspection, several large animal burrows were identified, which were repaired in June 2006. Otherwise, the site was in excellent condition, and site inspections should continue as scheduled.

\subsection{CAU 487: THUNDERWELL SITE (TTR)}

During the first site inspection three monuments were reported to be cracked. These monuments were repaired with sealant during the first inspection. The site appeared in good condition, and all monuments were upright, in place, and legible. Site inspections should continue as scheduled. 


\subsection{REFERENCES}

DOE/NV, see U.S. Department of Energy, Nevada Operations Office.

NNSA/NSO, see U.S. Department of Energy, National Nuclear Security Administration Nevada Site Office.

U.S. Department of Energy, Nevada Operations Office. 1997. Tonopah Test Range Closure Sites Revegetation Plan, DOE/NV/11718-115 UC-702. Las Vegas, NV.

U.S. Department of Energy, Nevada Operations Office. 1998a. Closure Report for Corrective Action Unit 404: Roller Coaster Sewage Lagoons and North Disposal Trench, Tonopah Test Range, Nevada, DOE/NV/11718-187 UC-702. Las Vegas, NV.

U.S. Department of Energy, Nevada Operations Office. 1998b. Closure Report for Corrective Action Unit 426: Cactus Spring Waste Trenches, Tonopah Test Range, Nevada, DOE/NV/11718-226 UC-702. Las Vegas, NV.

U.S. Department of Energy, Nevada Operations Office. 1999a. Closure Report for Corrective Action Unit 423: Area 3 Building 03-60 Underground Discharge Point, Tonopah Test Range, Nevada, DOE/NV/11718--319. Las Vegas, NV.

U.S. Department of Energy, Nevada Operations Office. 1999b. Closure Report for Corrective Action Unit 424: Area 3 Landfill Complexes, Tonopah Test Range, Nevada, DOE/NV/11718--283. Las Vegas, NV.

U.S. Department of Energy, Nevada Operations Office. 1999c. Closure Report for Corrective Action Unit 427: Area 3 Septic Waste Systems 2 and 6, Tonopah Test Range, Nevada, DOE/NV/11718--326. Las Vegas, NV.

U.S. Department of Energy, Nevada Operations Office. 1999d. Closure Report for Corrective Action Unit 453: Area 9 UXO Landfill, Tonopah Test Range, Nevada, DOE/NV/11718--284. Las Vegas, NV.

U.S. Department of Energy, Nevada Operations Office. 2001a. Closure Report for Corrective Action Unit 407: Roller Coaster RadSafe Area, Tonopah Test Range, Nevada, DOE/NV/11718--694-REV1. Las Vegas, NV.

U.S. Department of Energy, Nevada Operations Office. 2001b. Corrective Action Decision Document/Closure Report for Corrective Action Unit 487: Thunderwell Site, Tonopah Test Range, Nevada, DOE/NV/11718--761. Las Vegas, NV.

U.S. Department of Energy, National Nuclear Security Administration Nevada Site Office. 2004. Record of Technical Change No. 2 for the Final Corrective Action Decision Document/Closure Report for Corrective Action Unit 487: Thunderwell Site, Tonopah Test Range, Nevada, Revision 0, November 2001. Las Vegas, NV. 
U.S. Department of Energy, National Nuclear Security Administration Nevada Site Office. 2005. Record of Technical Change No. CR-1 for the Final Closure Report for Corrective Action Unit 423: Area 3 Building 0360 Underground Discharge Point, Tonopah Test Range, Nevada, Revision 0, July 1999. Las Vegas, NV. 
Post-Closure Inspection Report - TTR

Revision: 0

Date: June 2007

\section{Attachment A}

\section{FIGURES}


Post-Closure Inspection Report - TTR

Revision: 0

Date: June 2007

THIS PAGE INTENTIONALLY LEFT BLANK 


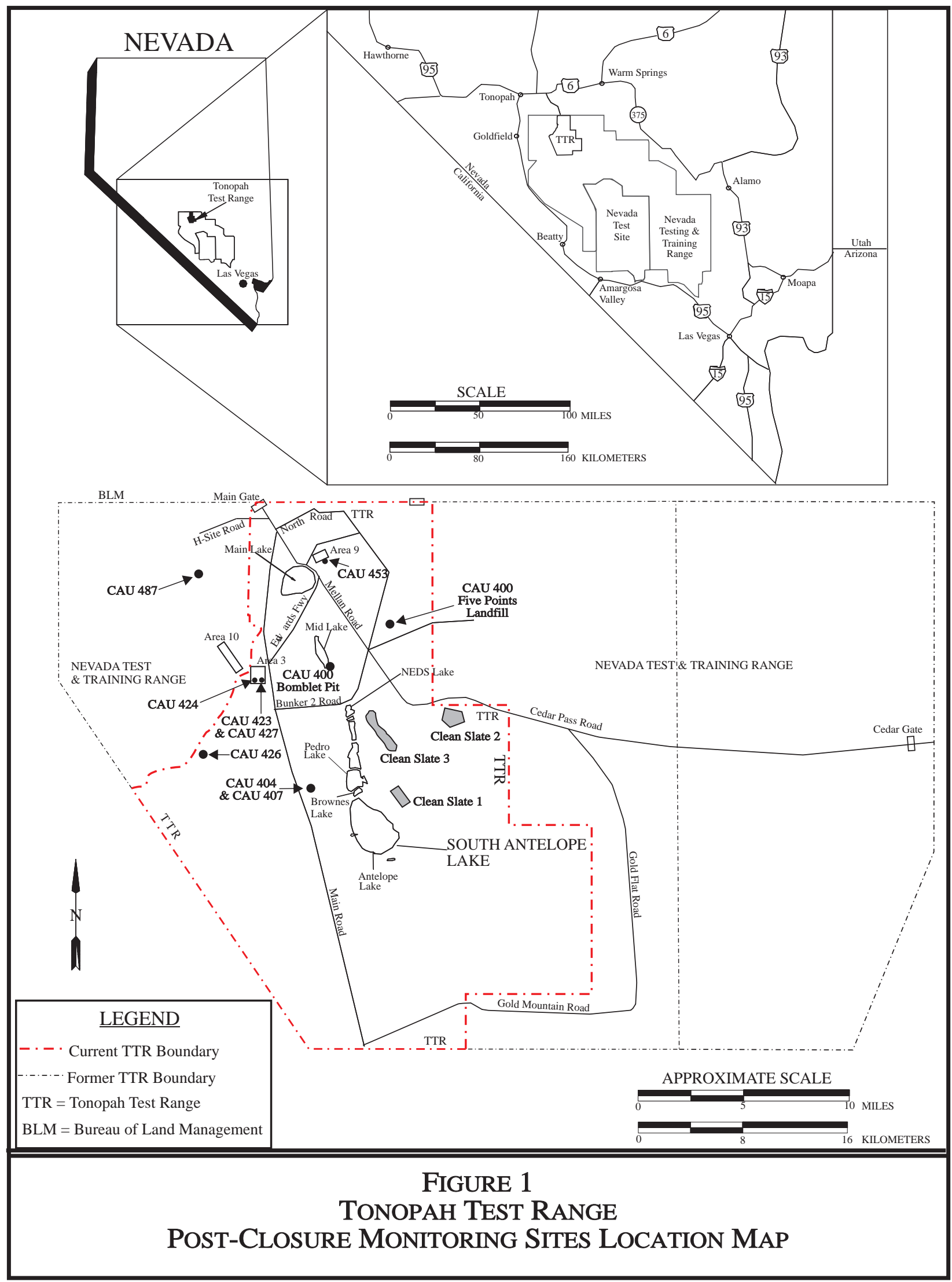




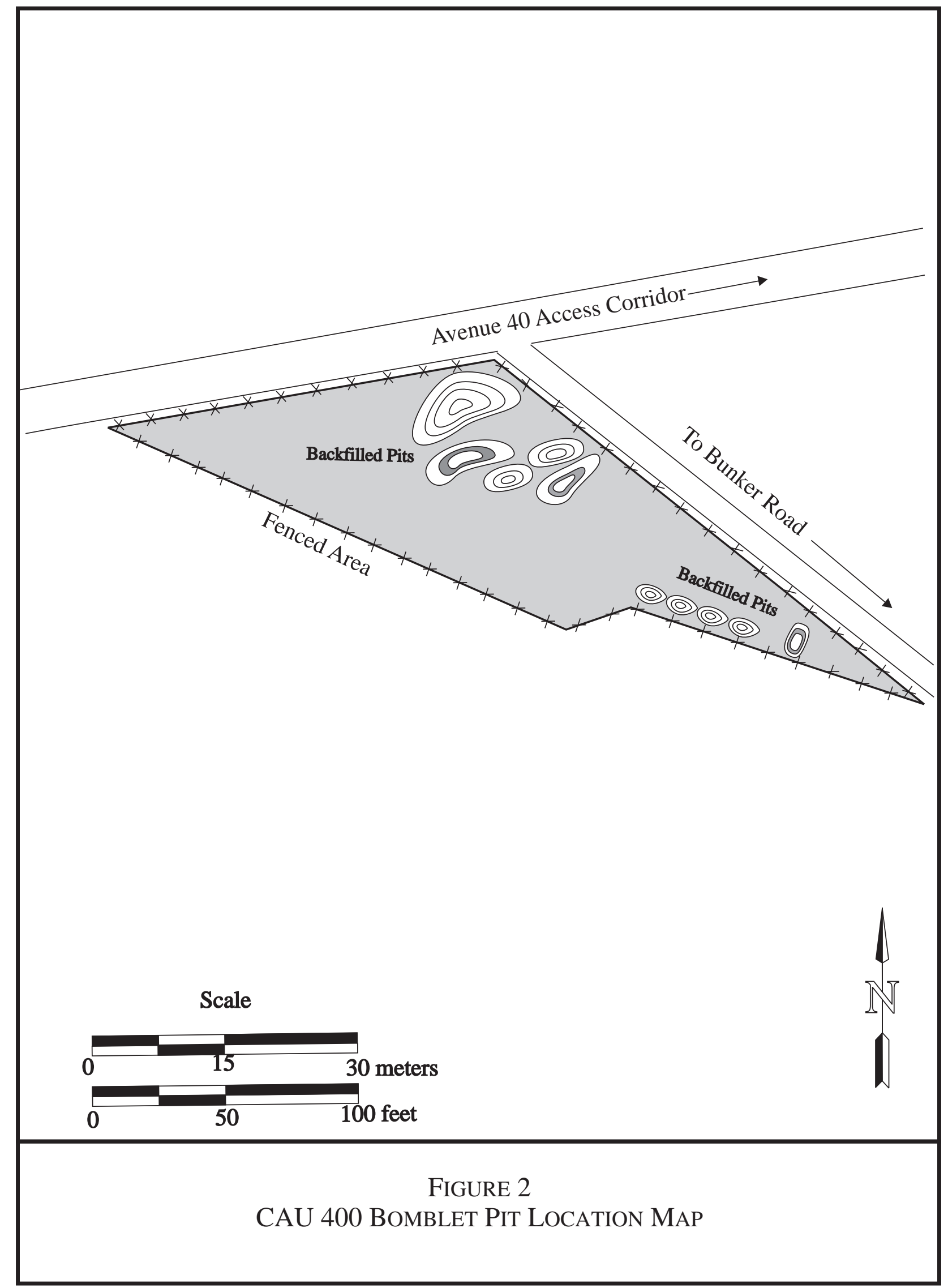




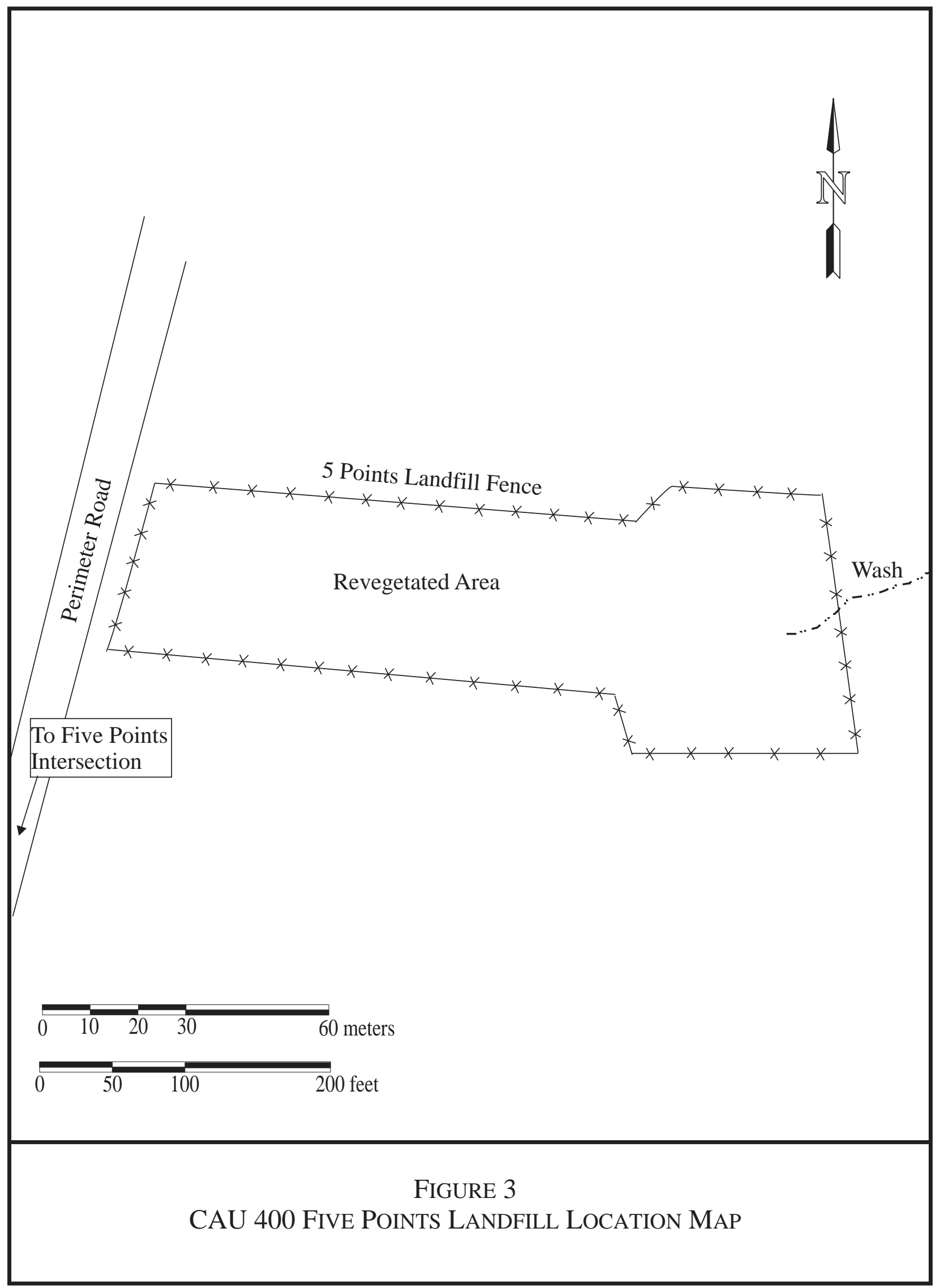




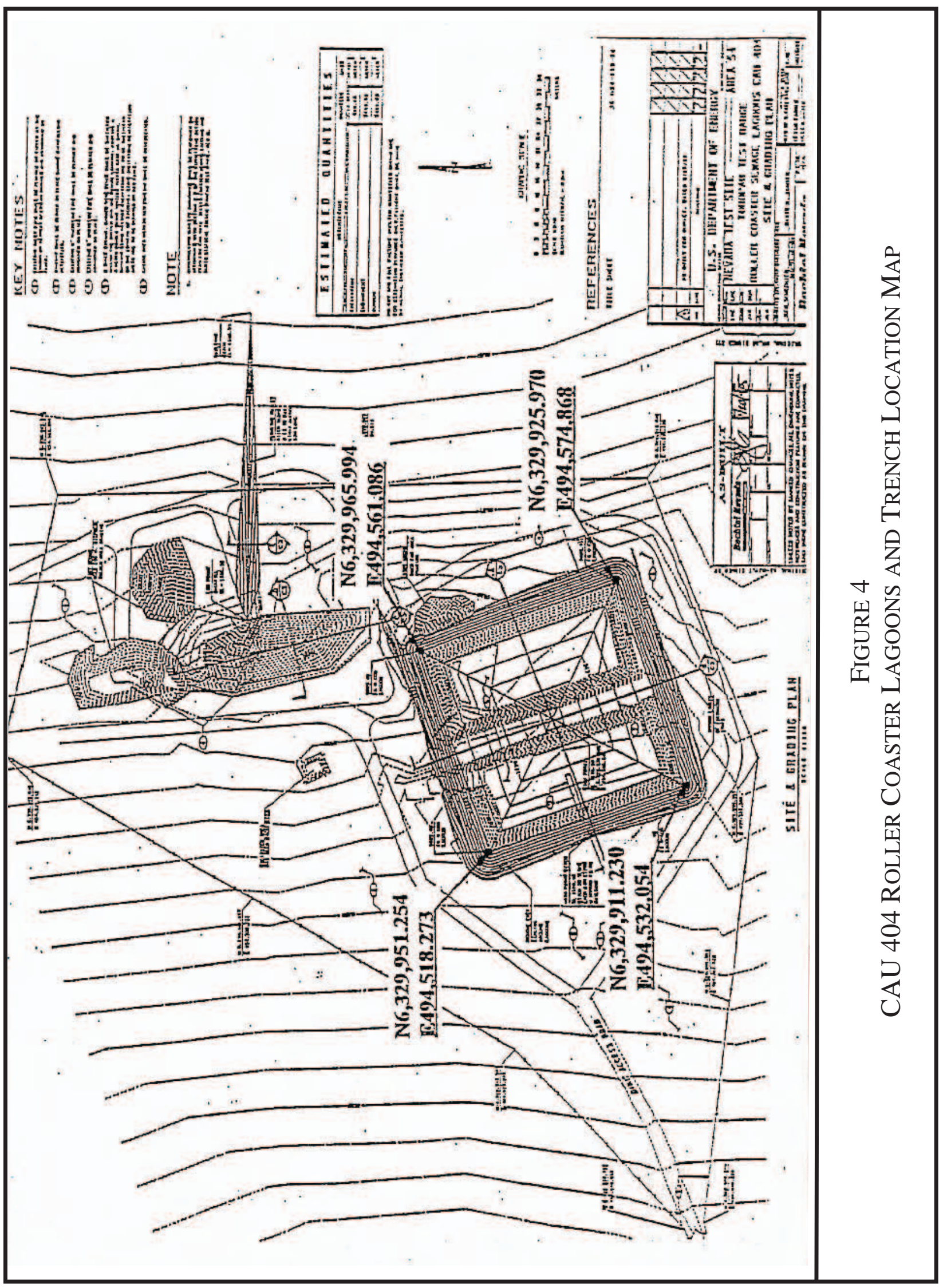




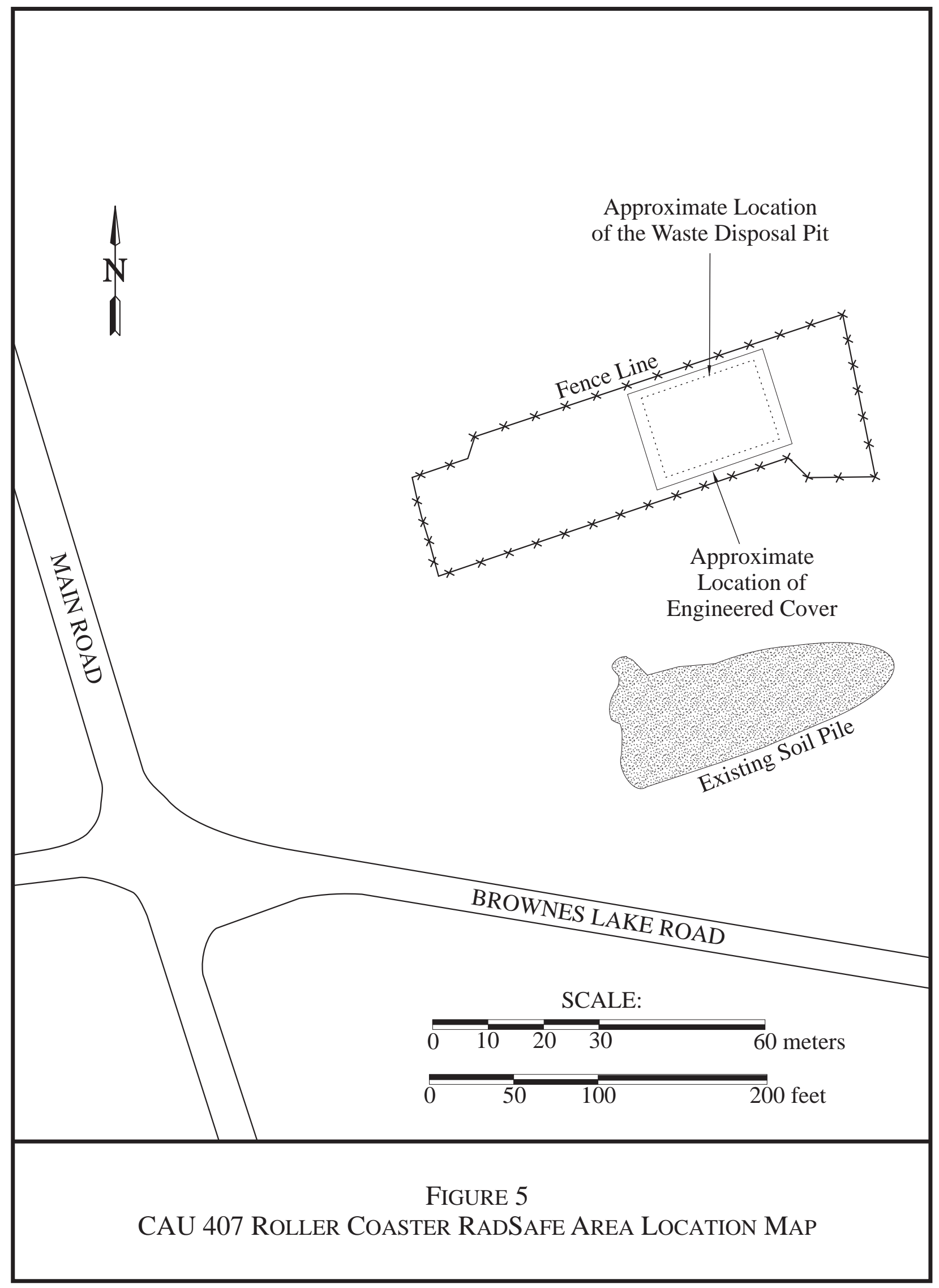




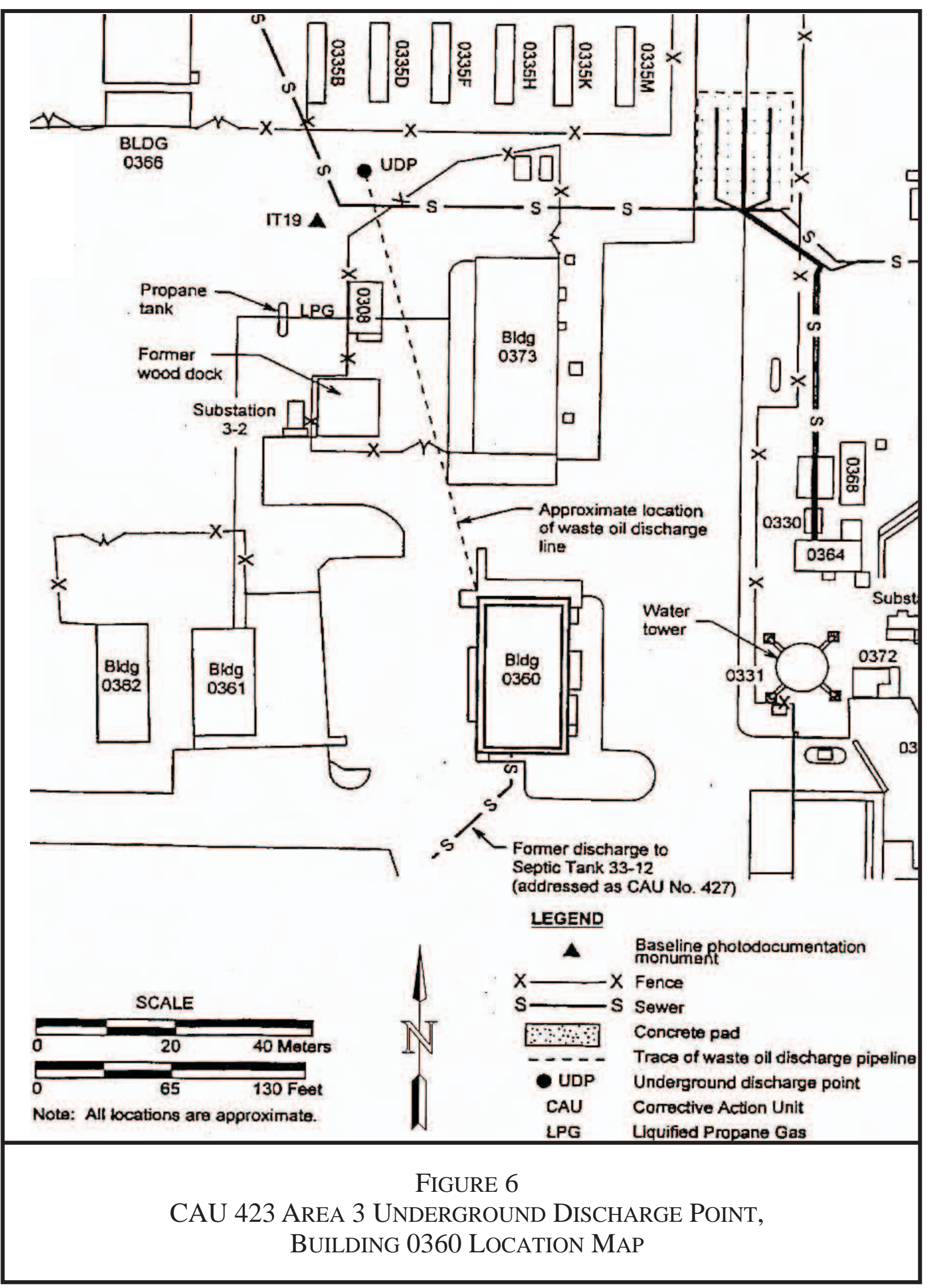




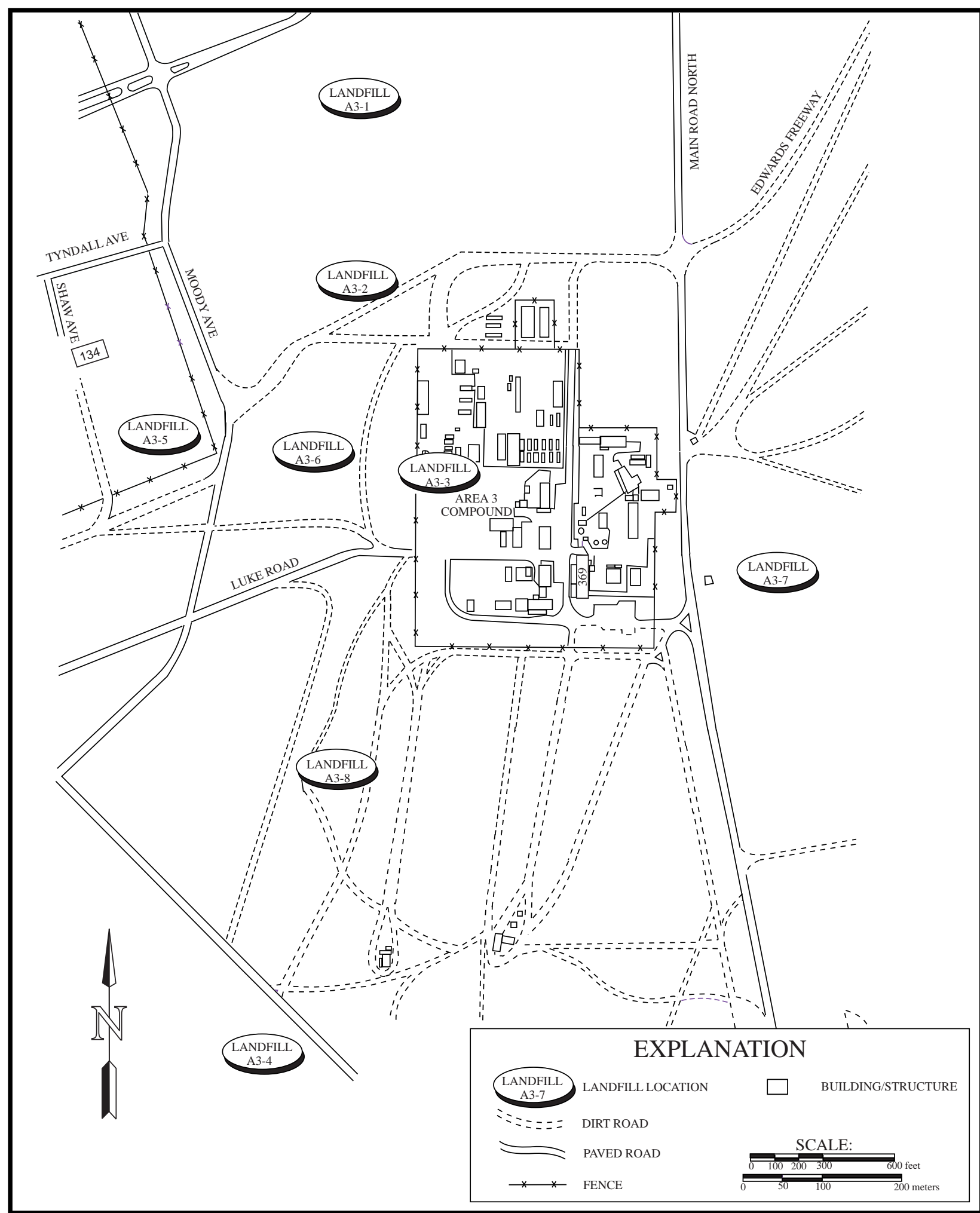

FIGURE 7

CAU 424 AREA 3 LANDFILL COMPLEXES LOCATION MAP 
Post-Closure Inspection Report - TTR

Revision:

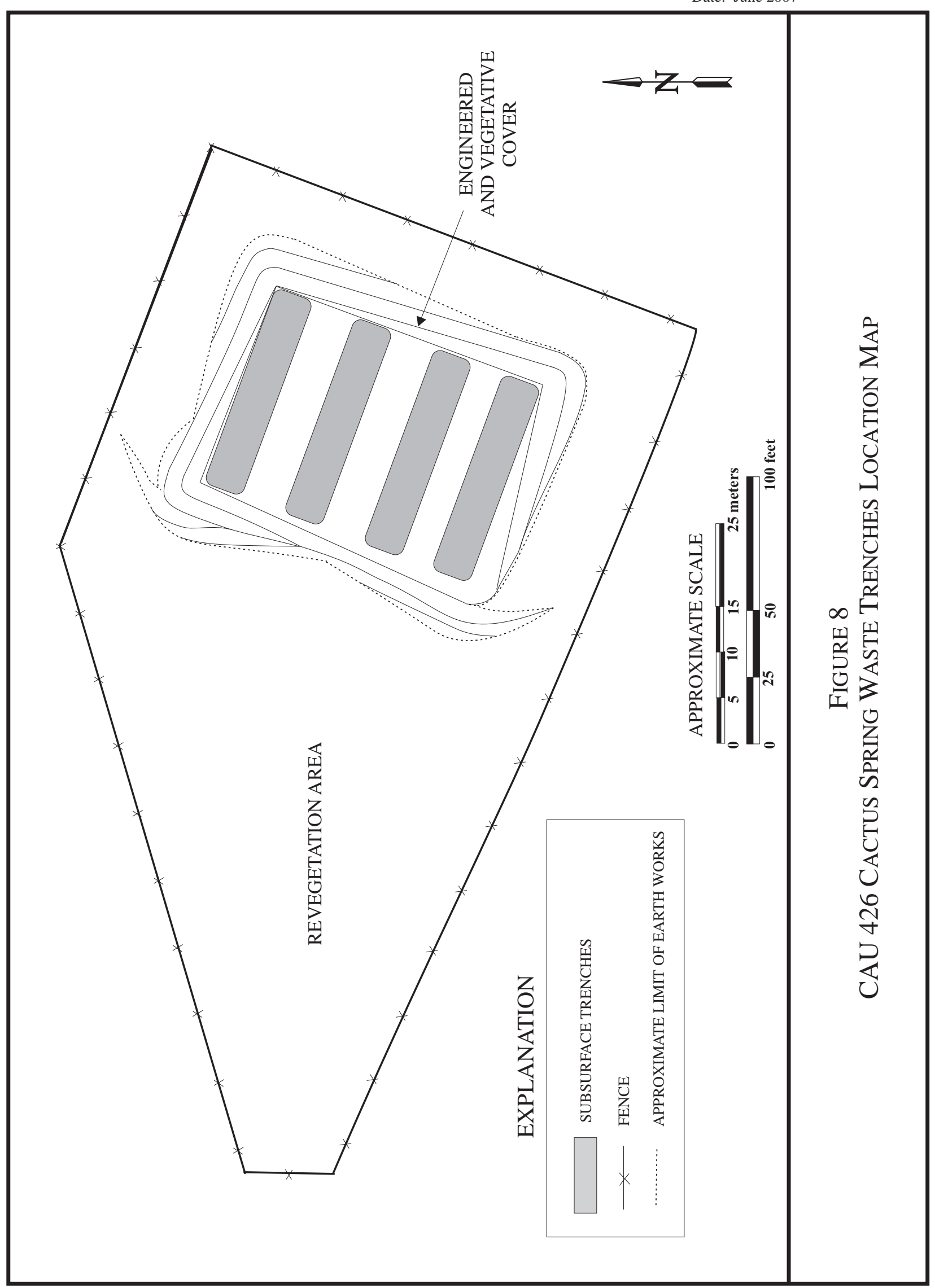

A-10 


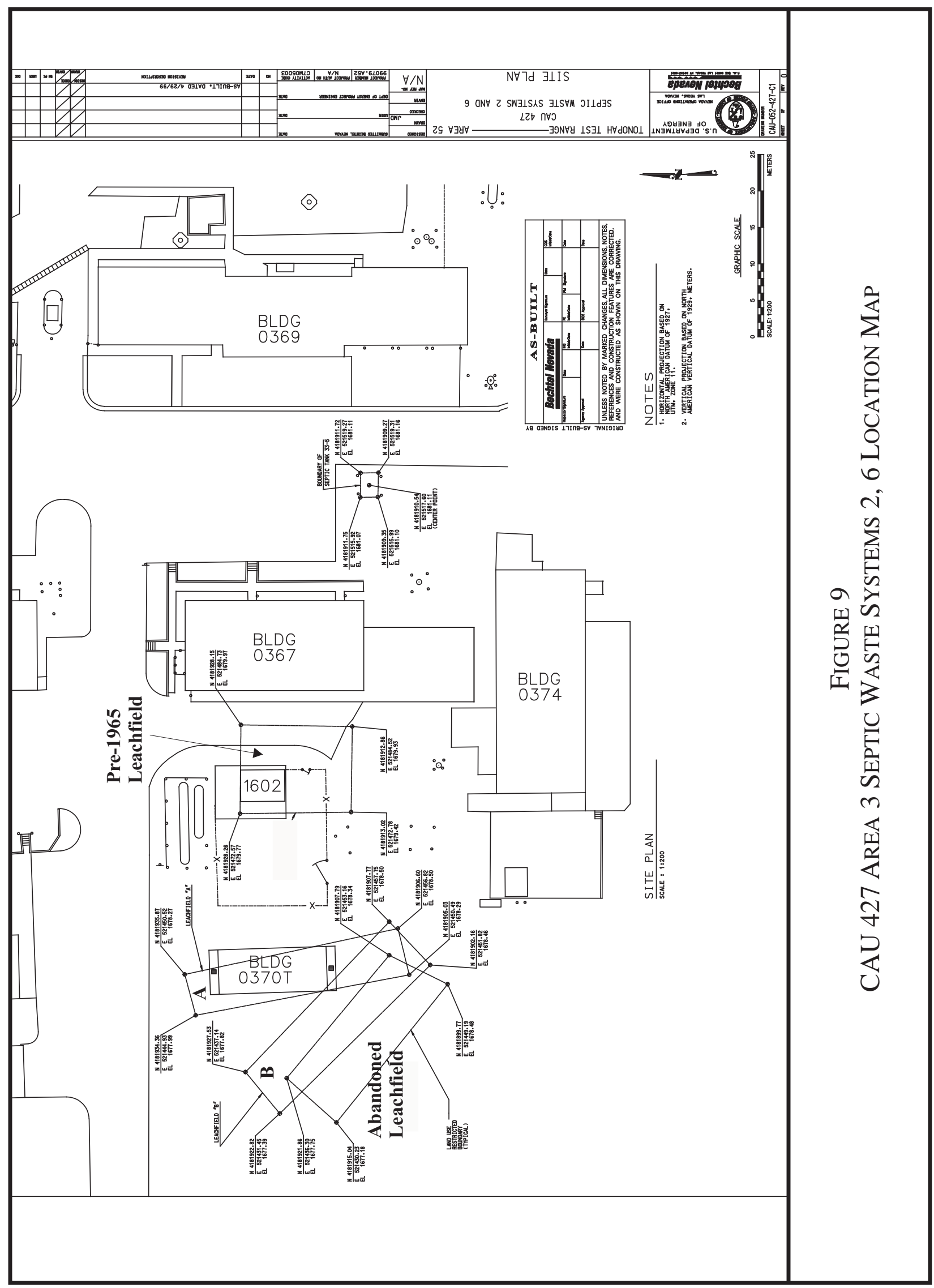


Post-Closure Inspection Report - TTR

Revision: 0

Date: June 2007

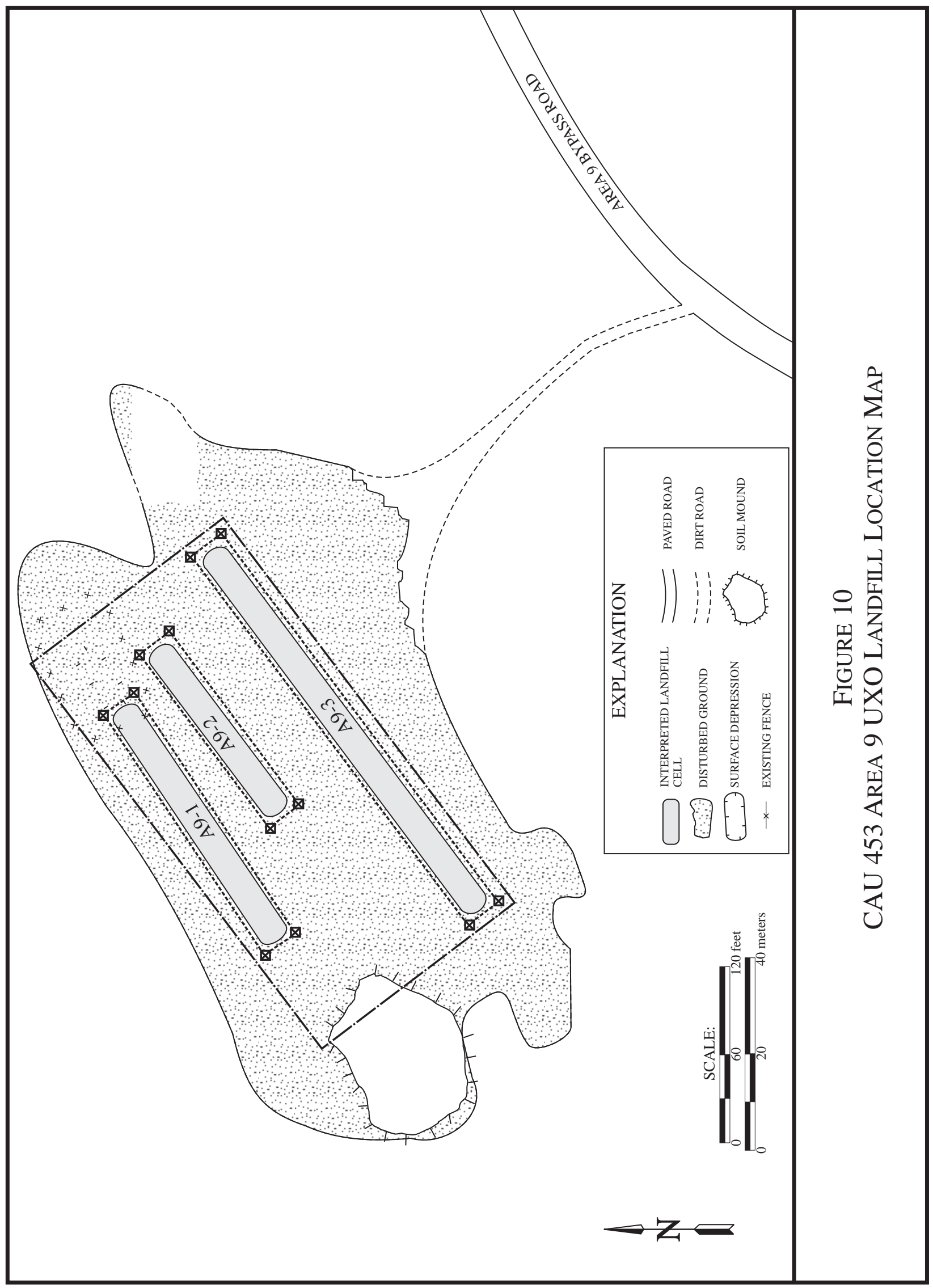




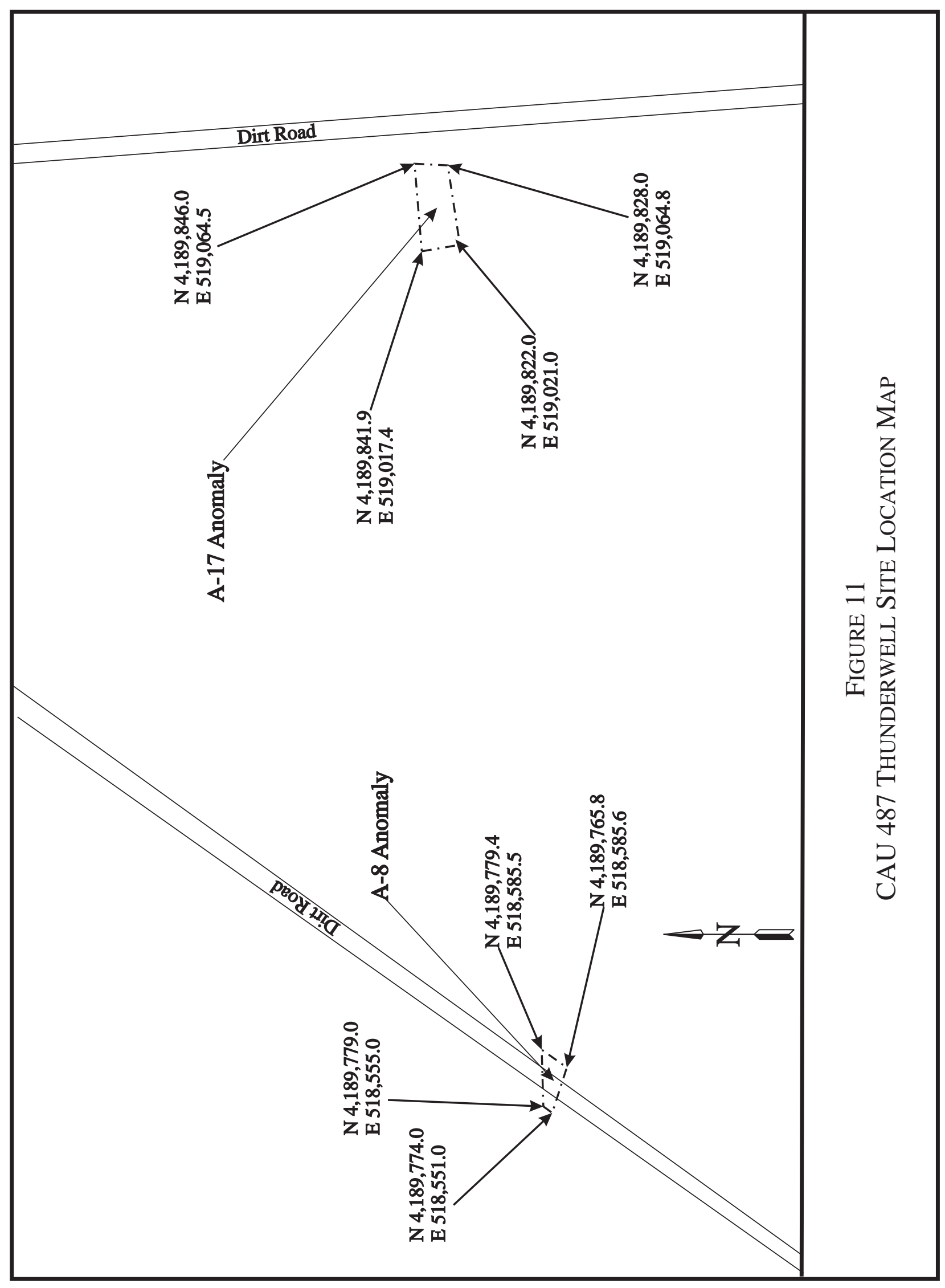


Post-Closure Inspection Report - TTR

Revision: 0

Date: June 2007

THIS PAGE INTENTIONALLY LEFT BLANK

A-14 
Post-Closure Inspection Report - TTR

Revision: 0

Date: June 2007

\section{AtTAChment B. Post-Closure Inspection Plans}


Post-Closure Inspection Report - TTR

Revision: 0

Date: June 2007

THIS PAGE INTENTIONALLY LEFT BLANK 


\section{CORRECTIVE ACTION UNIT (CAU) 404: ROLLER COASTER LAGOONS AND TRENCH POST-CLOSURE INSPECTION PLAN}

The following text appeared in the published and approved CAU 404 CR, $\underline{\text { Closure Report for }}$ Corrective Action Unit 404: Roller Coaster Sewage Lagoons and North Disposal Trench, Tonopah Test Range, Nevada, Revision 0, September 1998, DOE/NV-11718-187 UC-702.

Las Vegas, Nevada

Post-Closure monitoring of the covers is intended to determine:

- If maintenance repairs to the perimeter fence are required.

- If remedial action is necessary to establish a vegetative cover.

- If maintenance and repairs to the engineered cover is required.

- When a cessation to post-closure monitoring can be proposed.

\section{POST-CLOSURE MONITORING}

The monitoring will consist of biannual (twice per year) visual inspections of:

- The cover for condition (subsidence, significant erosion, unauthorized excavation, etc.) and plant development.

- The fence and signs to determine if repairs are required.

Additional, nonscheduled inspections may be required after severe weather events such as heavy rainfall, flash flooding, and high winds. Any identified maintenance and repair requirements will be remediated within 90 days of discovery and documented in writing at the time of repair. Additional revegetation work would be conducted during the next revegetation window (October to February).

Intrusion into or sampling of the impacted materials in the East or West Sewage Lagoon is not proposed during the post-closure monitoring period.

Monitoring of the vegetative cover will be conducted during the first, third, and fifth year after revegetation. Monitoring during the first year will determine if germination of seeded plant species has occurred. By the third year, plant establishment will be evaluated. By the fifth year, the objective of determining if burrowing animals have moved onto the site and to what depth they might be expected to penetrate the cover. The erosion condition of the soil will be evaluated using a qualitative erosion condition classification developed by the Bureau of Land Management. Information gathered will be compared to natural conditions and will be used in assessing whether or not remedial action is necessary so that a viable vegetative cover is established. 


\section{ANNUAL REPORTING}

An annual report will be prepared that will provide the observations and describe modifications and/or repairs made to the cover and cover area. The annual report will be prepared following the second inspection of each year that post-closure monitoring is conducted. The annual reports will include the following information:

- Discussion of observations

- Inspection checklist and maintenance record

- Conclusions and recommendations

A copy of each annual report will be submitted to the NDEP.

\section{DURATION}

The biannual inspections will be performed for five years after the planting of the vegetative covers, and will be documented on inspection forms.

Completion of post-closure monitoring of CAU 404 may be proposed after two consecutive years of visual inspections have not indicated the need to revegetate or provide maintenance to the vegetative covers. Completion of post-closure monitoring may be proposed within five years after the original revegetation of the site and include the removal of the fence since the plants will have attained a maturity to not be significantly affected by the grazing of wild horses. 


\section{CAU 407: ROLLER COASTER RADSAFE POST-CLOSURE INSPECTION PLAN}

The following text appeared in the published and approved CAU 407 CR, Closure Report for Corrective Action Unit 407: Roller Coaster RADSAFE Area, Tonopah Test Range, Nevada, Revision 1, December 2001, DOE/NV--694-rev 1. Las Vegas, Nevada

\section{INSPECTIONS}

Inspections consist of visually inspecting the cover for signs of erosion, animal burrows, cracks, water ponding, vegetation, and inspecting the fencing and postings. Inspections will be performed twice during the first six months after construction of the cover has been completed. After completion of the quarterly inspections, the cover systems will be inspected and monitored semiannually (twice per year) for the next two years. The frequency after the second year will be determined by NDEP, based on the results of the previous inspections. Any identified maintenance and repair requirements will be remedied within 90 working days of discovery and documented in writing at the time of repair.

Results of all inspections in a given year will be addressed in a single annual report. The annual report will include the following information:

- Discussion of observations.

- Inspection checklist and maintenance record.

- Conclusions and recommendations.

A copy of each annual report will be submitted to the NDEP. A copy of the inspection checklist is provided in Attachment $\mathrm{B}$. 
Post-Closure Inspection Report - TTR

Revision: 0

Date: June 2007

THIS PAGE INTENTIONALLY LEFT BLANK 


\section{CAU 423: AREA 3 BUILDING 0360 UNDERGROUND DISCHARGE POINT POST-CLOSURE INSPECTION PLAN}

The following text appeared in the approved and published Record of Technical Change Number CR-1 to the CAU 423 CR, Closure Report for Corrective Action Unit 423: Area 3 Building 03-60 Underground Discharge Point, Tonopah Test Range, Nevada, Revision 0, July 1999, DOE/NV/11718--319. Las Vegas, Nevada

Post-closure monitoring at CAU 423 will consist of biannual inspections (twice per year) to verify that the warning sign and concrete marker are in good condition and that the Use Restriction has been maintained. Any identified maintenance or repair requirements will be remedied within 90 working days of discovery and documented in writing at the time of repair. Results of all inspections in a given year will be addressed in a single annual report. The annual report will include the following information:

- Discussion of observations

- Inspection checklist and maintenance record

- Conclusions and recommendations

A copy of each annual report will be submitted to the NDEP. 
Post-Closure Inspection Report - TTR

Revision: 0

Date: June 2007

THIS PAGE INTENTIONALLY LEFT BLANK 


\section{CAU 424: AREA 3 LANDFILL COMPLEXES POST-CLOSURE INSPECTION PLAN}

The following text appeared in the published and approved CAU $424 \mathrm{CR}$, $\underline{\text { Closure Report for }}$ Corrective Action Unit 424: Area 3 Landfill Complexes, Tonopah Test Range, Nevada, Revision 0, July 1999, DOE/NV/11718--283. Las Vegas, Nevada

Post-closure inspection of the Area 3 Landfill sites is intended to determine:

- If maintenance repairs to the landfill soil covers are needed.

- If maintenance and repairs to the landfill markers and warning signs are needed.

- If modifications to the Use Restriction administrative controls are needed.

- If termination of post-closure inspection can be proposed in the future.

\section{POST-CLOSURE INSPECTION}

The inspection will consist of biannual (twice per year) visual inspections of:

- The soil cover for indications of subsidence, erosion, unauthorized use, etc.

- The landfill markers and warning signs, to verify they are in-place, intact, and readable.

- The inspections will be documented on a checklist and with photography, if needed.

If damage to the soil covers, landfill markers, or warning signs is noted, then maintenance will be performed and may include placement and compaction of additional backfill, and repair or replacement of markers and signs. Additional nonscheduled inspections may be required after severe weather events such as heavy rainfall, flash flooding, and high winds. Any identified maintenance and repair requirements will be remedied within 90 days of discovery and documented in writing at the time of repair.

\section{ANNUAL REPORTING}

An annual report will be prepared that will provide the observations and describe modifications and/or repairs made to the cover and cover area. The annual post-closure inspection report will be prepared and submitted to NDEP following the second inspection of each year that post-closure inspection is conducted. The annual reports will include the following information:

- Discussion of observations.

- Inspection checklist and maintenance record.

- Conclusions and recommendations.

\section{DURATION}

The biannual inspections will be performed for five years after the completion of closure activities, and will be documented on inspection forms. 
Completion of post-closure inspection of CAU 424 may be proposed by DOE/NV to the NDEP after two consecutive years of visual inspections have not indicated recurrence of subsidence. Completion of post-closure monitoring may be proposed by DOE/NV to the NDEP within five years after the completion of closure activities. 


\section{CAU 426: CACTUS SPRING WASTE TRENCHES POST-CLOSURE INSPECTION PLAN}

The following text appeared in the published and approved CAU 426 CR, Closure Report for Corrective Action Unit 426: Cactus Spring Waste Trenches, Tonopah Test Range, Nevada, Revision 0, August 1998, DOE/NV/11718-226 UC-702. Las Vegas, Nevada

Post-Closure of the covers is intended to determine:

- If maintenance repairs to the perimeter fence are required.

- If remedial action is necessary to establish a vegetative cover.

- If maintenance and repairs to the engineered cover is required.

- When a cessation to post-closure monitoring can be proposed.

\section{POST-CLOSURE MONITORING}

The monitoring will consist of biannual (twice per year) visual inspections of:

- The cover for condition (subsidence, significant erosion, unauthorized excavation, etc.) and plant development.

- $\quad$ The fence and signs to determine if repairs are required.

Additional, nonscheduled inspections may be required after severe weather events such as heavy rainfall, flash flooding, and high winds. Any identified maintenance and repair requirements will be remediated within 90 days of discovery and documented in writing at the time of repair. Additional revegetation work would be conducted during the next revegetation window (October to February).

Intrusion into or sampling of the trench contents is not proposed during the post-closure monitoring period.

Monitoring of the vegetative cover will be conducted during the first, third, and fifth year after revegetation. Monitoring during the first year will determine if germination of seeded plant species has occurred. By the third year, plant establishment will be evaluated. By the fifth year, the objective of determining if burrowing animals have moved onto the site and to what depth they might be expected to penetrate the cover. The erosion condition of the soil will be evaluated using a qualitative erosion condition classification developed by the Bureau of Land Management. Information gathered will be compared to natural conditions and will be used in assessing whether or not remedial action is necessary so that a viable vegetative cover is established. 


\section{ANNUAL REPORTING}

An annual report will be prepared that will provide the observations and describe modifications and/or repairs made to the cover and cover area. The annual report will be prepared following the second inspection of each year that post-closure monitoring is conducted. The annual reports will include the following information:

- Discussion of observations.

- Inspection checklist and maintenance record.

- Conclusions and recommendations.

A copy of each annual report will be submitted to the NDEP.

\section{DURATION}

The biannual inspections will be performed for five years after the planting of the vegetative covers, and will be documented on inspection forms.

Completion of post-closure monitoring of CAU 426 may be proposed after two consecutive years of visual inspections have not indicated the need to revegetate or provide maintenance to the vegetative covers. Completion of post-closure monitoring may be proposed within five years after the original revegetation of the site and include the removal of the fence since the plants will have attained a maturity to not be significantly affected by the grazing of wild horses. 


\section{CAU 427: AREA 3 SEPTIC WASTE SYSTEMS 2, 6 POST-CLOSURE INSPECTION PLAN}

The following text appeared in the published and approved CAU $427 \mathrm{CR}$, Closure Report for Corrective Action Unit 427 Area 3 Septic Waste Systems 2 and 6, Tonopah Test Range, Nevada, Revision 0, August 1999, DOE/NV--561. Las Vegas, Nevada

Post-Closure inspection of CAU 427 use restricted land is intended to determine:

- If maintenance and repairs to the closed leachfield or septic tank soil and asphalt covers are needed.

- If maintenance and repairs to the closed leachfield and septic tank markers and warning signs are needed.

- If modifications to the Use Restriction administrative controls are needed.

- If termination of post-closure inspection can be proposed in the future.

\section{POST-CLOSURE INSPECTION}

The inspection will consist of annual (once per year) visual inspections of:

- The soil and asphalt cover for indications of subsidence, erosion, unauthorized use, etc.

- The leachfield and septic tank markers and warning signs to verify they are in-place, intact, and readable

- The inspections will be documented on a checklist (Attachment C) and, if needed, with photography

Repairs to the soil covers (placement and compaction of additional backfill), landfill markers, and warning signs (repair, reposition, and/or replacement) may be required.

Inspections are not required after severe weather events such as heavy rainfall, flash floods, and high winds, because the leachfield waste is buried in the subsurface. However, any identified maintenance and repair requirements noted before or after a inspection will be remedied within 90 days of discovery and documented in writing at the time of repair.

\section{ANNUAL REPORTING}

An annual report will provide the inspector's observations of CAU 427s land-use-restricted areas and describe modifications and/or repairs made to Leachfield A, Leachfield B, Pre-1965 Leachfield, 1965-1975 Leachfield, and/or Septic Tank 33-5. The annual post-closure inspection report will be prepared and submitted to NDEP before the completion of the fiscal year in which the inspection was conducted. The annual reports will include the following information:

- Discussion of observations.

- Inspection checklist and maintenance record. 
- Conclusions and recommendations.

\section{DURATION}

The biannual inspections will be performed for five years after the completion of closure activities, and will be documented on inspection forms.

Completion of post-closure monitoring of CAU 427 may be proposed by the DOE/NV to the NDEP if after two consecutive years of visual inspections, indications of subsidence depression recurrences have not been detected. Completion of post-closure inspection may be proposed by $\mathrm{DOE} / \mathrm{NV}$ to the NDEP within five years after the completion of closure activities. 


\section{CAU 453: AREA 9 UXO LANDFILL INSPECTION PLAN}

The following text appeared in the published and approved CAU 453 CR, Closure Report for Corrective Action Unit 453: Area 9 UXO-Landfill, Tonopah Test Range, Nevada, Revision 0, July 1999, DOE/NV/11718--284. Las Vegas, Nevada

Post-Closure of the covers is intended to determine:

- If maintenance and repairs to the cell soil covers are needed.

- If maintenance and repairs to the perimeter fence, warning signs, and monuments are needed.

- If modifications to the administrative Use Restrictions are needed.

- If termination of post-closure inspection can be proposed in the future.

\section{POST-CLOSURE INSPECTION}

The inspection will consist of biannual (once per year) visual inspections of:

- The cell soil cover, for indications of subsidence, erosion, unauthorized use, etc.

- The perimeter fence, warning signs, and monuments, for signs of wear disturbance, etc.

The inspections will be documented on a checklist and with photography, if needed. Repairs to the cell soil covers (placement and compaction of additional fill), perimeter fence, warning signs, and monuments (repair, reposition, and/or replacement) may be required. Additional, nonscheduled inspections may be required after severe weather events such as heavy rainfall, flash flooding, and high winds. Any identified maintenance and repair requirements will be remediated within 90 days of discovery and documented in writing at the time of repair.

\section{ANNUAL REPORTING}

An annual post-closure inspection report will be prepared that will provide the observations and describe modifications and/or repairs made to the cover and cover area. The annual report will be prepared and submitted to NDEP following the second inspection of each year that post-closure inspection is conducted. The annual reports will include the following information:

- Discussion of observations.

- Inspection checklist and maintenance record.

- Conclusions and recommendations.

\section{DURATION}

The biannual inspections will be performed for five years after the completion of closure activities, and will be documented on inspection forms. 
Completion of post-closure inspection of CAU 453 may be proposed by DOE/NV to NDEP within five years after the completion of closure activities. Completion of post-closure inspection may also be proposed by DOE/NV to NDEP if two consecutive years of visual inspections do not indicate the recurrence of subsidence depressions. 


\section{CAU 487: THUNDERWELL SITE, POST-CLOSURE INSPECTION PLAN}

The following text appeared in the published and approved Record of Technical Change Number 2 for the final Corrective Action Decision Document/Closure Report for Corrective Action Unit 487: Thunderwell Site, Tonopah Test Range, Nevada, Revision 0, November 2001, DOE/NV--761. Las Vegas, Nevada

The post-closure inspection of CAS RG-26-001-RGRV will consist of semi-annual (twice per year) visual inspections of the monument markers and postings to verify that they are in-place, intact, and readable. Visual inspections of the monuments and signage, and indications of ground disturbance within the Use Restriction area will be conducted. Observations and any modifications and/or repairs to the monuments or postings will be included in the annual Post-Closure Inspection Report for the Tonopah Test Range, Nevada. 
Post-Closure Inspection Report - TTR

Revision: 0

Date: June 2007

\section{THIS PAGE INTENTIONALLY LEFT BLANK}


Post-Closure Inspection Report - TTR

Revision: 0

Date: June 2007

\section{ATTACHMENT C. Post-Closure InSPECTION CHECKLISTS}


Post-Closure Inspection Report - TTR

Revision: 0

Date: June 2007

THIS PAGE INTENTIONALLY LEFT BLANK 


\begin{tabular}{|c|c|c|c|}
\hline \multicolumn{4}{|c|}{ CAU 400: BOMBLET PIT, POST-CLOSURE INSPECTION CHECKLIST } \\
\hline \multicolumn{4}{|l|}{ Inspection Dill: $\quad 5 / 31 / 06$} \\
\hline Responsible Agency: NNSA/NSO ERR & \multicolumn{3}{|c|}{ NNSA Project Managcr: K̈́vior Cab6/e } \\
\hline Date of Last luspection: $\quad 1 / / 15 / 05$ & \multicolumn{3}{|c|}{ Reason for last luspection: Seni-Annual } \\
\hline \multicolumn{4}{|l|}{ Inspector (mante nitle organizatinn): Glenn Kiehardson } \\
\hline \multicolumn{4}{|l|}{ Assistant Inspector (mance nitle. organization): Reed Poderis } \\
\hline \multicolumn{4}{|c|}{ 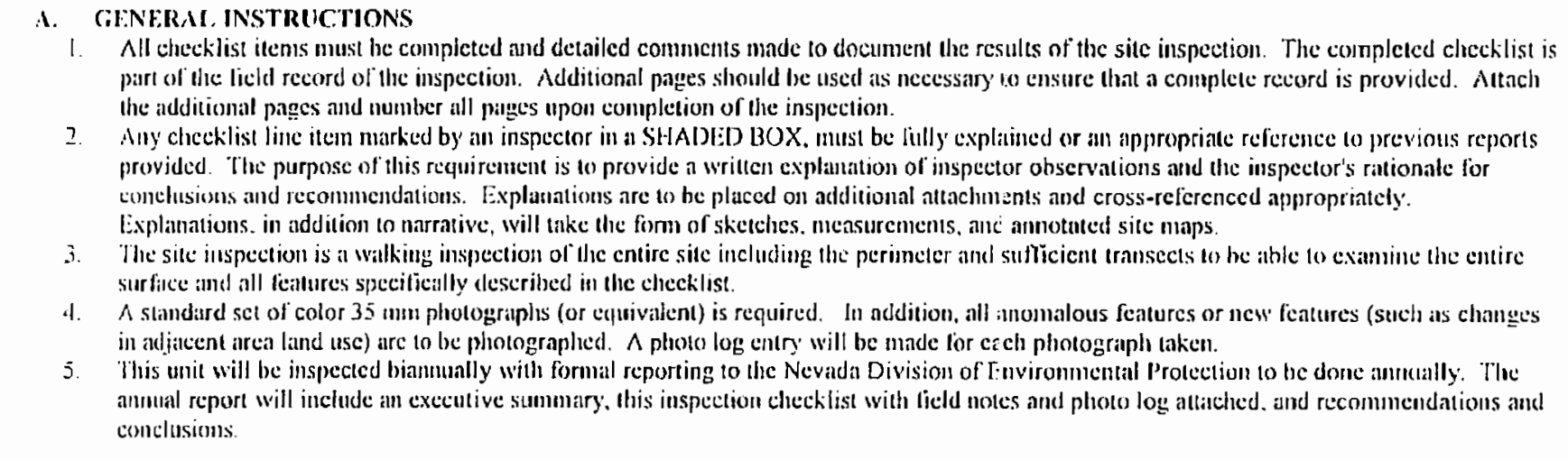 } \\
\hline B. PREP:ARATION (To be completed prior to sile visii) & YES & nO & EXPLANATION \\
\hline 1. Sitc as-built plans and sitc basc map reviewed. & $x$ & & \\
\hline \multirow{3}{*}{$\begin{array}{l}\text { 2. I'revious inspection reports reviewed. } \\
\text { it. Were anomalies or Irents delected on previnus inspections? } \\
\text { b. Was mantenunce performed! }\end{array}$} & $x$ & & \\
\hline & & $\therefore$ & \\
\hline & & $\therefore$ & \\
\hline \multirow{3}{*}{ 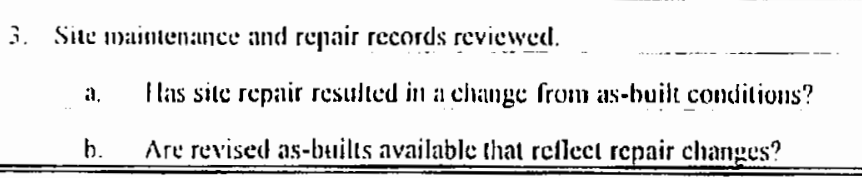 } & $x$ & & \\
\hline & & $x$ & \\
\hline & & $x$ & $N / A$ \\
\hline c. STTE IASIECTUN (Th be compleled during inspection) & YISS & 140 & EXPLANATION \\
\hline \multicolumn{4}{|l|}{ 1. Ndjacent ofl-site leatures within watershad arcias. } \\
\hline a. Lave there been any changes in use of adjacent areal? & & $x$ & \\
\hline b. Are there any new' roands or trivils? & & $x$ & \\
\hline c. Has there been a chinge in the pusition of nearhy washes? & & $\therefore$ & \\
\hline $\begin{array}{l}\text { d. Has there been lateral excursion or crosion/deposition of nearlyy } \\
\text { washes"? }\end{array}$ & & $x_{2}$ & \\
\hline c. Are there new drainage chamncls? & & $\underline{x}$ & \\
\hline t. Chienge in surroundulg vegetation!". & & $x^{\circ}$ & \\
\hline 2. Sicurily lence, signs, & & & \\
\hline $\begin{array}{l}\text { "Displatement of fences, sile mirkers, boundary markers, or } \\
\text { monuments"? }\end{array}$ & & $\underline{x}^{\prime}$ & \\
\hline $\begin{array}{l}\text { b. Have iny signs becu damaged or removed"? } \\
\text { (Number of signs replaced: }\end{array}$ & & $k^{\prime}$ & \\
\hline c. Werc gilles locked"? & & $\underline{x}$ & No Lack becanse there is nes \\
\hline
\end{tabular}




\begin{tabular}{|c|c|c|c|}
\hline \multicolumn{4}{|c|}{ CAU 400: BOMBLET PIT, POST-CLOSURE INSPECTION CHECKLIST } \\
\hline \multirow{2}{*}{$\begin{array}{l}\text { 3. Waste Unir cover. } \\
\text { a. Is there evidence of sectling? }\end{array}$} & \multirow[t]{2}{*}{ YES } & \multicolumn{2}{|c|}{ NO EXPI.ANATION } \\
\hline & & $x$ & \\
\hline \multirow{2}{*}{$\begin{array}{l}\text { b. Is there cracking? } \\
\text { c. Is there cvidence of erosion around the cap (wind or water)? }\end{array}$} & & $x$ & \\
\hline & & $\not$ & \\
\hline \multirow{4}{*}{ 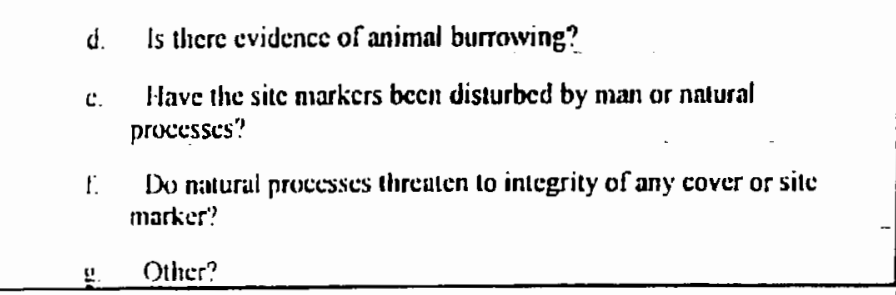 } & & & \\
\hline & & $x$ & \\
\hline & & $x$ & \\
\hline & & $x$ & $N / A$ \\
\hline \multicolumn{4}{|l|}{ 4. Veugctative cover. } \\
\hline \multirow{4}{*}{ 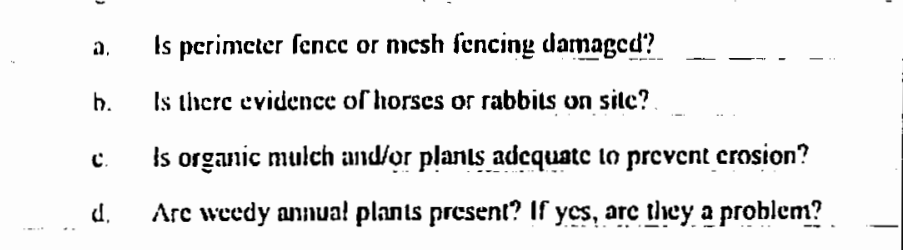 } & \multirow[t]{2}{*}{$x$} & & \multirow{2}{*}{$\begin{array}{l}\text { Chicken wire fiacing is damaged } \\
\text { on east side off feence. } \\
\text { whot }\end{array}$} \\
\hline & & 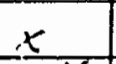 & \\
\hline & $x$ & 212 & \\
\hline & & $+x$ & \\
\hline \multirow{2}{*}{$\begin{array}{l}\text { c. Are seeded plant species found on silc"? } \\
\text { i. Is there cvidence ol plant mortality" }\end{array}$} & $x$ & & \\
\hline & & 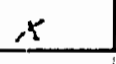 & \\
\hline \multicolumn{4}{|l|}{ 5. Pholo Documentition _ _................ } \\
\hline a. Has a photo log been prepared? & $\underline{x}$ & & \\
\hline \multicolumn{3}{|l|}{ c. Number of photos exposed ( 3 ) } & \\
\hline \multicolumn{4}{|l|}{ D. FIELD CONCLUSIONS } \\
\hline $\begin{array}{l}\text { 1. Is there an inminemt hazard to the integrity of the unit? (Immediate repon } \\
\text { requircl) }\end{array}$ & & $x$ & \\
\hline \multicolumn{4}{|l|}{ Personi/Agency to whom report made: } \\
\hline \multicolumn{2}{|l|}{ 2. Arc marc frequent inspections required? } & $x$ & \\
\hline 3. Arc cxisting mainterauce/repair aclions salisfactory? & $x$ & & \\
\hline $\begin{array}{l}\text { 3. Arc existing mainterauce/repair aclions salisfaclory? } \\
\text { 4. Is other naintenauce/repair necessary? }\end{array}$ & $x$ & & $\begin{array}{l}\text { Chickem mise fewering beedt } \\
\text { repair. }\end{array}$ \\
\hline 5. Is currem status/condition of vegetative cover satisfactory? & $x$ & & \\
\hline \multicolumn{4}{|c|}{ 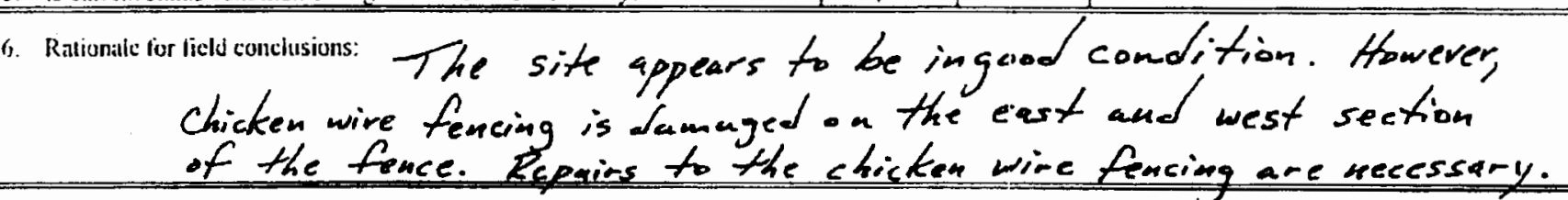 } \\
\hline \multicolumn{4}{|c|}{ E. CERTIRICATION } \\
\hline \multicolumn{4}{|c|}{$\begin{array}{l}\text { I have conducted an inspection of the Bomblet Pit, CAU 400, at the TTR in accordanec with the Post-Closurc Monitoring l'lan (sec Closure Repore) as } \\
\text { recorded on this checklist. altached shects, field noles, phoolo logs, and ghodgeraphs. }\end{array}$} \\
\hline \multirow[t]{2}{*}{ Chier luspector's Signature: } & \multicolumn{3}{|c|}{ Prinued Name: Glene thicharoisan } \\
\hline & Dalc: & $5 / 31$ & \\
\hline
\end{tabular}


CAU 400: BOMBLE' PIT, POST-CLOSURE INSPECTION CHECKLIST

Inspection Date: $\quad 11 / 15 / 06$

Responsible Agency: NNSA/NSO ER

Date of Last Inspection:

$5 / 31 / 06$ NNSA Project Manager: Pete Sanders Reason for Last laspection: Semi-Annual Inspector (name, titlc, organization): Task Mamager, $N 5 T$ Ce $E R$ Assistant inspector (name, title, organization): Reed Poderis, Technical Manayer, NSTeC ER

ג. GENERAL. INSTRUCIIONS

1. All checklist items must be completed and detailed comments made to document the results of the site inspection. 'The conpleted checklist is part of the field record of the inspection. Additional pages should be used as necessary to ensure that a complete record is provided. Altach tile additional pages and number all pages upon completion of the inspection.

2. Any checklist litc item markerl by an inspector in a SHADED BOX, must be fully explained or an appropriate reference to previous reports provided. The purpose of this requirement is to provide a written explanation of inspector observations and the inspeetor's mationale tor conclusions and recommendations. Explanations are to be placed on additional attachments and cross-reterenced appropriately. Explanations, in addition to narrative, will take the form of sketches, measurements, and annotated site majs.

3. The site inspection is a walking inspection of the entire site incleding the perimeter and suffieient transects to be able to exannine the entire surface and all fertures specifically deseribed in the cleceklist.

4. A standard set of color $35 \mathrm{~mm}$ photographs (or equivalcent) is required. In addition, all momalous features or new features (such as changes in adjacent area land usc) are (1) be phntographed. $\wedge$ photo log entry will be made for eaclo photograph taken.

5. This unit will be inspected biannually with formal reporting to the Nevida Division of Environmental Protection to be done annually. The anmual report will include an executive summary, this inspection checklist with field notes and pioto log altached, and recommendat ions and conclusions.

\begin{tabular}{|c|c|c|c|}
\hline B. PREPARATION (To be completed prior to site visit) & YES & NO & EXPLANATION \\
\hline 1. Site as-built plans andl site base map reviewed. & $x$ & & \\
\hline 2. Previous inspection reports reviewerl. & $x$ & & \\
\hline \multirow{2}{*}{$\begin{array}{l}\text { a. Were anomalies or trends detected on previous inspections? } \\
\text { b. Was maintenance perlormed? }\end{array}$} & & $x$ & \\
\hline & $x$ & 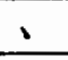 & $\begin{array}{l}\text { Foncerepairs wers completed in } \\
\text { Iute zoog. }\end{array}$ \\
\hline 3. Site maintenance and repair records reviewed. & $\Delta$ & & \\
\hline \multirow{2}{*}{$\begin{array}{l}\text { a. Has site repair resulted in a change from as-built conditions?' } \\
\text { b. Are revised as-huilts available that rellect repair changes? }\end{array}$} & & $x$ & \\
\hline & & & $N / A$ \\
\hline C. SITE INSPECTION (To be completed during inspection) & YES & No & EXPLANATION \\
\hline \multicolumn{4}{|l|}{ 1. Adjacent off-site features wilhin watershed areas. } \\
\hline a. Have there been any changes in use of ndjacent area? & & $x$ & \\
\hline b. Are tlere any new ronds or trails? & & $x$ & \\
\hline c. His there been a change in the position of nearby washes? & & $x$ & \\
\hline $\begin{array}{l}\text { d. Has there been lateral excursion or erosion/leposition of neirby } \\
\text { washes? }\end{array}$ & & $x$ & \\
\hline \multirow[t]{2}{*}{ c. Are there new drainage chamnels? } & & $x$ & \\
\hline & & $x$ & \\
\hline \multicolumn{4}{|l|}{ 2. Security fence, signs. } \\
\hline $\begin{array}{l}\text { a. Displacement of lences, site markers, boundary markers. or } \\
\text { inoiuunents? }\end{array}$ & & $x$ & . \\
\hline $\begin{array}{l}\text { b. Have any signs been damaged or removed? } \\
\text { (Number of signs replaced: }\end{array}$ & & X & \\
\hline c. Were gates lnckod? & & & $N / A$ \\
\hline
\end{tabular}




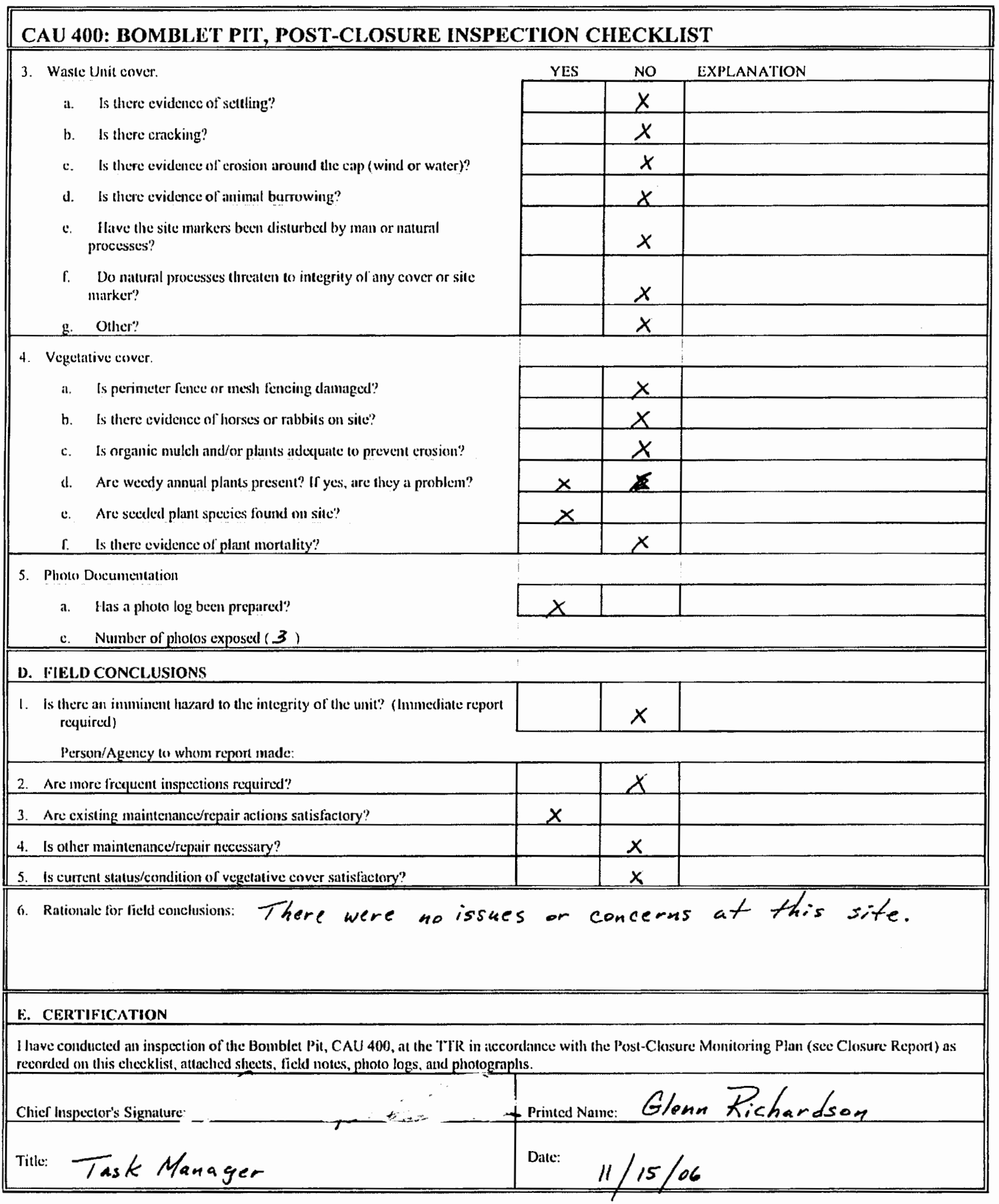




\section{CAU 400: 5 POINTS LANDFILL, POST-CLOSURE INSPECTION CHECKLIST}

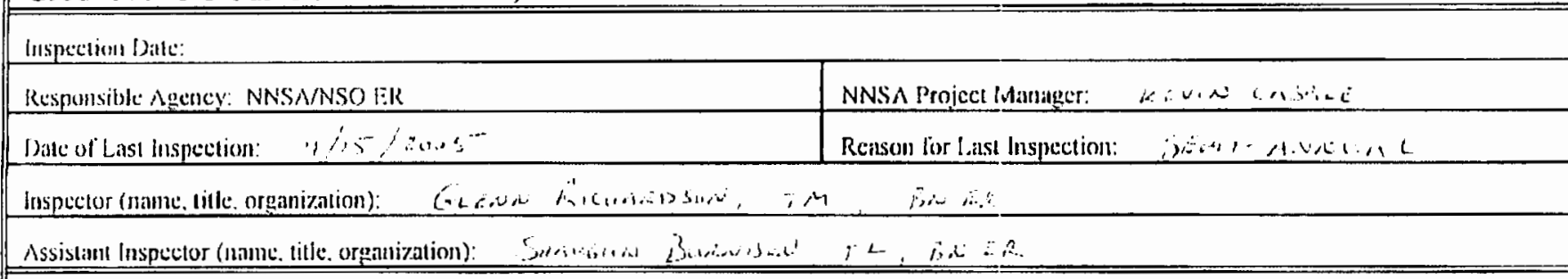

\section{A. GLNERAI. INSTRLICTIONS}

1. All checklist items must be completed and detniled comments made to document the rtisults of the site inspection. The eompleted eliecklist is part of the lield record of the inspection. Additional pages should be used its necessary tu clisture that a complete record is provided. Altach the additiontial pitges and mumber all pages upon completion of the inspection.

2. Any checkilist line ilem mirked by an inspector in a SH LADLO BOX, must be fully explaned or ant approprialte reterence lo previous reports provided. The purpose of this requirenem is co provide a written explanation of inspeceor observations and the inspector's rationale for conclusicns and recommendations. Fexplanations are to be placed on additional altacher.ents and cross-referenced appropriately. Explanations, in addition to nurrative, will take the form of sketches, meisurements, and anmotaled site maps.

3. The site inspection is a walking inspection of the entire site including the perineter and sutlicient transects in be able to exannine the cutire sutfisec and all features specilically deseribed in the clecklist.

4. A standard set of color $35 \mathrm{~mm}$ photographs (or equivalent) is required. In addition, all anomalous features or new features (such is thanges ill adjacent arrei land use) are to be photographed. A photo log entry will be made for eicl photograph takent.

5. This unit will be inspected biamnaally will formal reporting to the Nevada Division of Linviromental Protectien to be done annualty. The ammal repors will include an exceutive stummary, this inspection checklist with field no es and photo log attached, and recommenditions and conclusions.

\begin{tabular}{|c|c|c|c|}
\hline B. PREPARATION (To be completed prior to site visit) & YES & $\mathrm{NO}$ & EXPI.ANATION \\
\hline 1. Sitc is-built plaus ind site base maj reviewed. & $\therefore$ & & \\
\hline 2. Previous inspection reports reviewed. & $x$ & & \\
\hline \multirow{2}{*}{$\begin{array}{l}\text { it Were anmolies or trends delected on previous inspections? } \\
\text { b. Was maintenance performed? }\end{array}$} & & 5 & \\
\hline & & K & \\
\hline \multirow{2}{*}{$\begin{array}{l}\text { 3. Site maintenance ind repair records revicwecl. } \\
\text { it. Ilas sitc repair resultecl in at change from as-built conditions? }\end{array}$} & 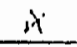 & & \\
\hline & & is & \\
\hline b. Are revised as-buills ivailable that rellect repair changes? & & $x$ & $\omega / A$ \\
\hline C. SITE INSIECCION (To be compleled during inspection) & YES & ino & EXPLANATION \\
\hline \multicolumn{4}{|l|}{ 1. Acliacent off-sitc features within watershed artas. } \\
\hline it. Have there been inyy changes in use of adjacent aren?" & & 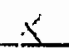 & \\
\hline b. Are there any uew roads or trails? & & $x$ & \\
\hline c Has llere been a change in He position of uearby washes? & & $x$ & \\
\hline $\begin{array}{l}\text { d. Has there been Interil exeursion or erosion/depessition of nearby } \\
\text { washes? }\end{array}$ & & 火 & \\
\hline$\therefore \quad$ Ace there new drainage channels? & & $x$ & \\
\hline l. Chinge in surrounding yegetation? & & $2 i$ & \\
\hline \multicolumn{4}{|l|}{ 2. Securily fence, signs. } \\
\hline $\begin{array}{l}\text { a. Displacement of feitces, sile mathers, boundiry markers, or } \\
\text { monuments? }\end{array}$ & & $x$ & \\
\hline $\begin{array}{l}\text { b. Ilave any sigas been dantaged or removed"? } \\
\text { (Nuntber of signs replaced: }\end{array}$ & & $\therefore$ & \\
\hline Were gales locked"? & & $x$ & No lack wn rate \\
\hline
\end{tabular}




\section{CAU 400: 5 POINTS LANDFILL, POST-CLOSURE INSPECTION CHECKLIST}

3. Walste Unit cover

a. Is there cuiducte of suthlinge?

b. Is lloce craching?"

c. Is there evilence of erosion around the cap (wist or water)?

d. Is there cvidence of animal burrowing?

c. Have the site markers been disturbed by man or natural processes?

f. Do nitural processes fluceaten to integrity of any cover or site markcr?

a. Sher?

\begin{tabular}{|c|c|c|}
\hline YES & NO & EXPLANATHON \\
\hline & 5 & \\
\hline & $x$ & \\
\hline & $x$ & \\
\hline$x$ & & 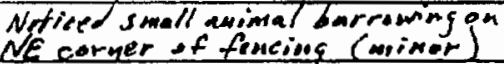 \\
\hline & 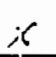 & \\
\hline & $x$ & \\
\hline & $x$ & $N / A$ \\
\hline
\end{tabular}

4. Venclallive cover.

a. 1s perimeter fence or mesh fencing diamiged?

h. Is licere evidenet ol lorses or rabbits on site?

c. Is organic mulch and/or plants adequale to prevent crosion?

d Are weedy amual plants present? If yes, are they a problem?

Ł. Are seeded plant species found on sitc"?

i. Is there evidenec of plant mortality?

;. Photo Docimatonation

a. Lass a photo log becon prepared!"

\begin{tabular}{|l|l|l|}
\hline & $x$ & \\
\hline & $x$ & \\
\hline
\end{tabular}

c. Numiber of photos exposed ( /)

\section{Hithin (OONCI,ISIONS}

1. Is there in imminent hazird to lle incegrity ol the unit?) (Immediate report required)

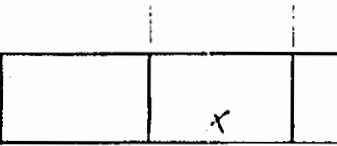

Person/Agency lo whom report made:

\begin{tabular}{|c|c|c|c|}
\hline 2. Are more fres|ucnl inspections recpured"? & & $x$ & \\
\hline 3. Are existing matulcuance/repair actions sittisfactory? & $x$ & $16 x^{2}$ & \\
\hline 4. Is ofler maintenance/repair necessury"? & & $\underline{x}$ & \\
\hline 5. Is current statusicondition of vegetative cover satisfictory? & $x$ & & \\
\hline
\end{tabular}

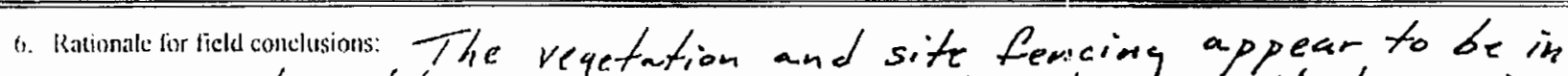
good condition. There are no signifienet issues that pequine a follow-up uction.

\section{E. CERTIFICATION}

I lave conducted an inspection of the 5 Points landfill, CAU 400, at the TTR in accordance with the Post-Closure Monitoring Plan (see Closure Report) as recorded on this checklist, attached shects, field untes, photeg fogs, apdygholographs.

Chief' Inspecior's Sigmanture:

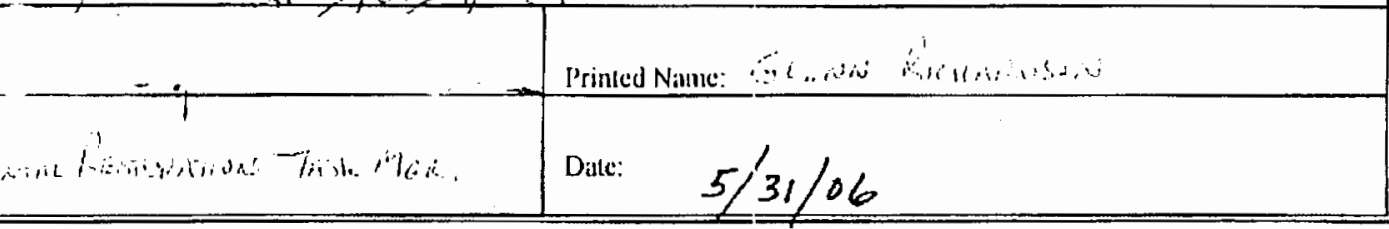


CAU 400: 5 POINTS LANDFILL, POST-CLOSURE INSPEC'TION CIIECKLIST

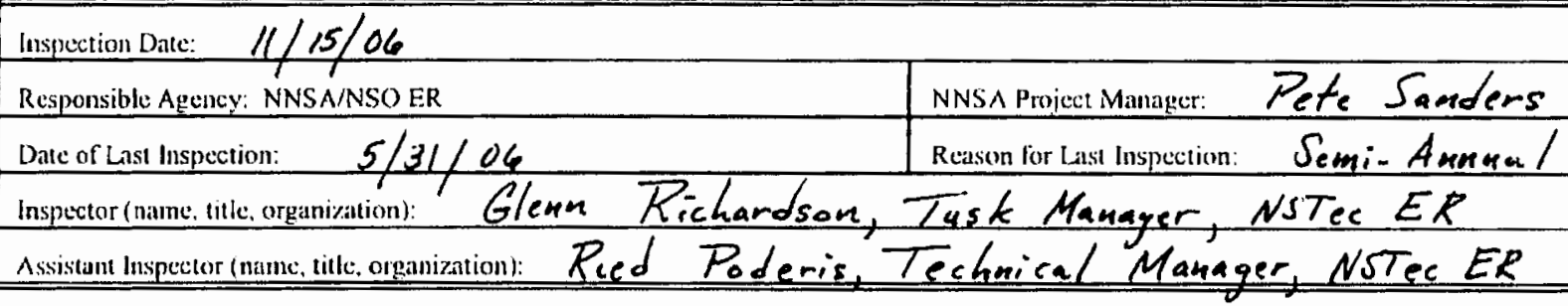

A. GENERAL INSTRUCTIONS

1. All checklist items must be completed and detailed comments made to document the results of the site inspecion. The eompleted checklist is part of the field record of the inspection. Additional pages should be used as necessary to ensure that a complete record is provided. Attach the additioual pages and number all pages upon complecion of the inspection.

2. Any eliecklist liae item marked hy an inspector in a SHADED BOX, must be fully explained or an appropriate reference to previous repors provided. The purpose of this requirement is to provide a written explanation of inspector observations and the inspector's rationale for conclusions and recommendations. Explanations are to be placed on additional attaclunents and eross-referenced appropriately Explanntions, in addition to natrative, will take the form of sketcles, measurements, and annotated site maps.

3. The site inspection is a walking inspection of the entire site including the perimeter and sufficient transects to be able to exannine the entire surface and all features specificilly described in the clocklist.

4. A staudard set of color $35 \mathrm{~mm}$ photographs (or equivalent) is required. In addition, all anomalous features or new features (such as changes in adjacent areat land use) are to be photographed. A photo log entry will be made for each photograph taken.

5. This unit will be inspected biannually swith fonnal reporting to the Nevada Division of Environmental Protection to be done annually. The annual report will include an exceutive sumnary, this inspection checklist wilh field notes ind photo fog attached, and reeconmendations anol conclusions.

\begin{tabular}{|c|c|c|c|}
\hline B. PREPARATION (To be completed prior to site visit) & YES & NO & EXPLANATION \\
\hline 1. Site as-built plans and sitc base map reviewed. & $x$ & & \\
\hline 2. Previons inspection reponts reviewed. & $\underline{x}$ & & \\
\hline a. Were anomalies or trends detected on previous inspections? & & $x$ & \\
\hline b. Was maintenance perforned? & & $X$ & \\
\hline 3. Site maintenance and repair records reviewed. & $x$ & & . \\
\hline a. Llas sitc repair resulted in a change from as-built conditions? & & $X$ & \\
\hline b. Are revised as-huills availahle that reflect repair changes? & & & $N / A$ \\
\hline C. SITE INSPECTION (To be completed during inspection) & YES & NO & EXPLANATION \\
\hline \multicolumn{4}{|l|}{ 1. Adjacent off-site features within witershed arcas. } \\
\hline a. Have there been any clanges in use of adjacent area? & & $X$ & \\
\hline b. Are there any new roads or trails"? & & $x$ & \\
\hline c. Has there been a change in tlec position of neaby washes? & & $X$ & \\
\hline $\begin{array}{l}\text { d. Has there heen lateral excursion or crosion/deposition of nearby } \\
\text { washes? }\end{array}$ & & $X$ & \\
\hline c. Are there new drainage channels? & & $x$ & \\
\hline i. Change in surrounding vegetation? & $X$ & & $\begin{array}{l}\text { Veget jtion is dead clue } 7 . \\
\text { fleeding in the area. }\end{array}$ \\
\hline \multicolumn{4}{|l|}{ 2. Security lience. signs. } \\
\hline $\begin{array}{l}\text { a. Displacement of fences, site markers, houndary markers, or } \\
\text { monuments? }\end{array}$ & & $X$ & \\
\hline $\begin{array}{l}\text { b. Have iny signs been danaged or removed". } \\
\text { (Number of signs replaced: }\end{array}$ & & $X$ & \\
\hline c. Were gates locked? & & & $N / A$ \\
\hline
\end{tabular}




\section{CAU 400: 5 POINTS LANDFILL, POST-CLOSURE INSPECTION CHECKLIST}

3. Waste Unit cover.
a. Is there evidence of setling?
b. Is there cracking?
c. Is there cvidence of erosion around the cap (wind or water)?
d. Is there evidence of animal butrowing?
c. Have the site markers been disturbed by man or natural processes?
f. Do natural processes threaten to imegrity of any cover or sile markcr?
g. Oulur?

4. Vegetative conver.

a. Is perineter fence or mesh fencing danaged"?

b. Is there evidence of horses or rabibits on site?

e. Is organic mulch and/or plants adoxuate to prevent crosiom?

d. Are weedy annual plants present? If yes, are they a problem?

c. Are seeded plant species found on site"?

i. Is there evidence of plant mortality?

\begin{tabular}{|c|c|l|}
\multicolumn{1}{|c|}{ YLS } & NO & EXPLANATION \\
\hline & $x$ & \\
\hline & $x$ & \\
\hline$x$ & $x$ & $\begin{array}{l}\text { small evidense of animal burrowing } \\
\text { near feont of fence. }\end{array}$ \\
\hline & $x$ & \\
\hline & $x$ & \\
\hline & $x$ & \\
\hline
\end{tabular}

5. Photo Docuncintation

a. Has a photo log been prepared?

c. Number of plontos exposed ( 3 )

\section{FIELD CONCLUSIONS}

1. Is there an imninent hazard to the integrity of the unit?' (Immediate report required)

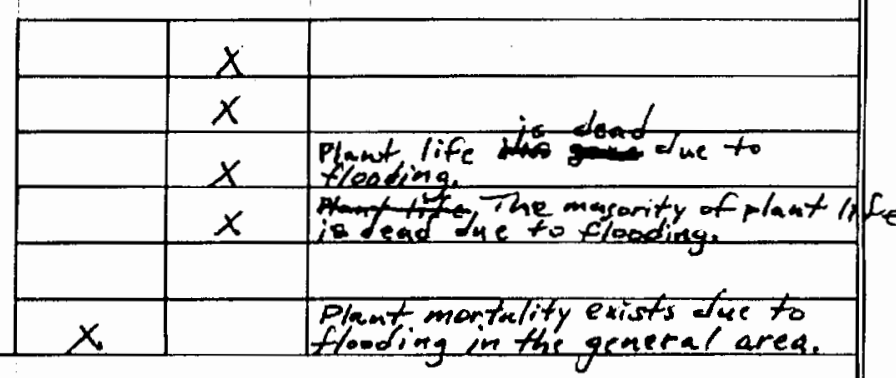

Person/Agency to whom report nade:

2. Are more frequent inspections requireal?

3. Are existing maintenallce/repair actions satisfactory?

4. Is other maintenance/repair necessary?

5. Is current status/condition of vegetalive cover satishetory?

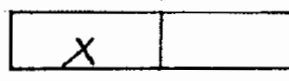

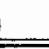




\section{CAU 404: ROLLER COASTER LAGOONS \& N. DISPOSAL TREINCH, POST-CLOSURE MONITORING CHECKLIST}

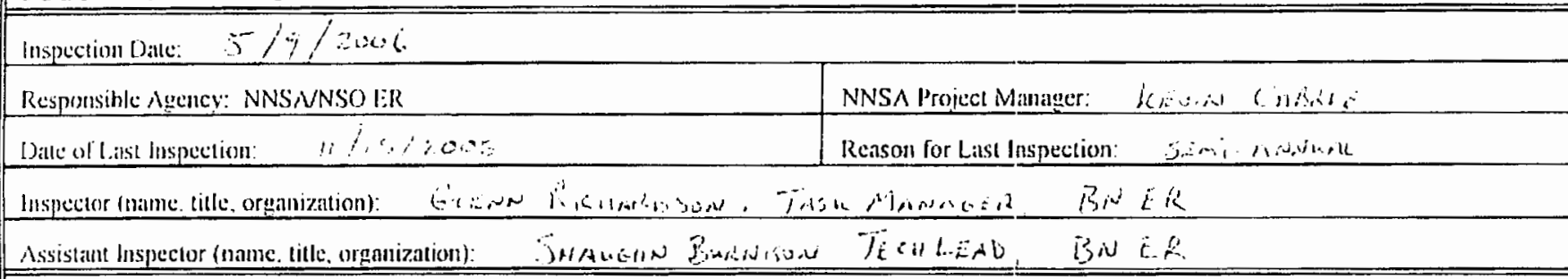

\section{A. GFNERIL INSTRUCIONS}

1. All checklist items must be completed and detailed comments made to document the results of the site inspection. The completed checklist is part of the field record of the inspection. Additional pages should be used as necessary lo ensure that an complete record is prowided. Altach the idditional pages and number all pages upon eompletion of the inspection.

2. Any eluecklist line item marked by an inspector in is SIINDISD I3OX, must be fully explanned or an appropriate reference to previons reports provided. The purpose of this requirement is to provide a written explanation of inspecter observations and the inspector's rationale tor concitusions and recommendations. Explanntions are to be placed on additional altachnents and cross-reterenced appropriatcly.

Lxplanations, in addition to narrative, will take the form or sketches. meisurements, and annotited site mups

3. The site inspection is a walking inspection of the entire sitc including the perimeter and sulficient tramsects o be able to cxamine the entire surlace aud all fealtures specifically deseribed in the clecklist.

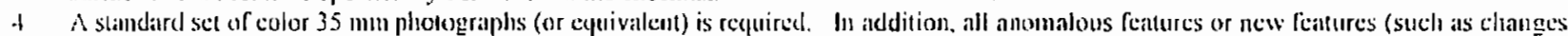
in adjacent area land use) are tabe photographed. A photo log entry will be made lor cand photograph baken.

5. This unit will be inspected biannually witl fomial reporting in the Nevada Division of Environmentual Protection to he done anmually. The annual report will include an excentive sumniary, this inspection checklist with ficld notes and photo log attached, and recommendotions and conclusions.

\begin{tabular}{|c|c|c|c|}
\hline 13. PRESPARATION (To be completed prior to site visit) & YES & No & EXPLANATION \\
\hline I Site as-built plans and site base map revicwed. & $x$ & & \\
\hline 2. Provious inspection reports reviewed. & $\therefore$ & & \\
\hline \multirow{2}{*}{$\begin{array}{l}\text { a Were anomalies or trends detected on previous intspections") } \\
\text { b. Was mintenance performed? }\end{array}$} & & 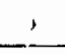 & \\
\hline & & $y$ & \\
\hline \multirow{3}{*}{ 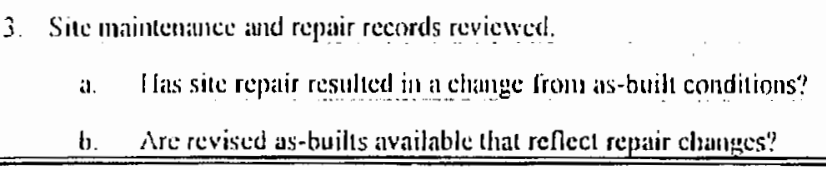 } & 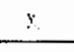 & & \\
\hline & & $\therefore$ & \\
\hline & & $\because$ & $N / 4$ \\
\hline (: SITE INSPEC CION (To be completed during inspection) & YES & NO & I:XPLANATION \\
\hline
\end{tabular}

1 Aljacent off-site leatures within watershed areass.

it Have there been any changes in use of adjacent areal?

b. Are there any new roids or tritls?

c. Has there becn a change in the position of nearby washes?

d. Has llecre been lateral excursion or trosiom/deposition of ncarby watiles"?

c. Are there new drainage channels?

l. Change in surrounding vegethtion?

2. Security fence. signs.

a. Displacement ol fences, sile markers, houndary markers, or monuments:?

b. Have any signs been danniaged or remıved? (Nunber of sigus replaced:

c. Were gates lucked?

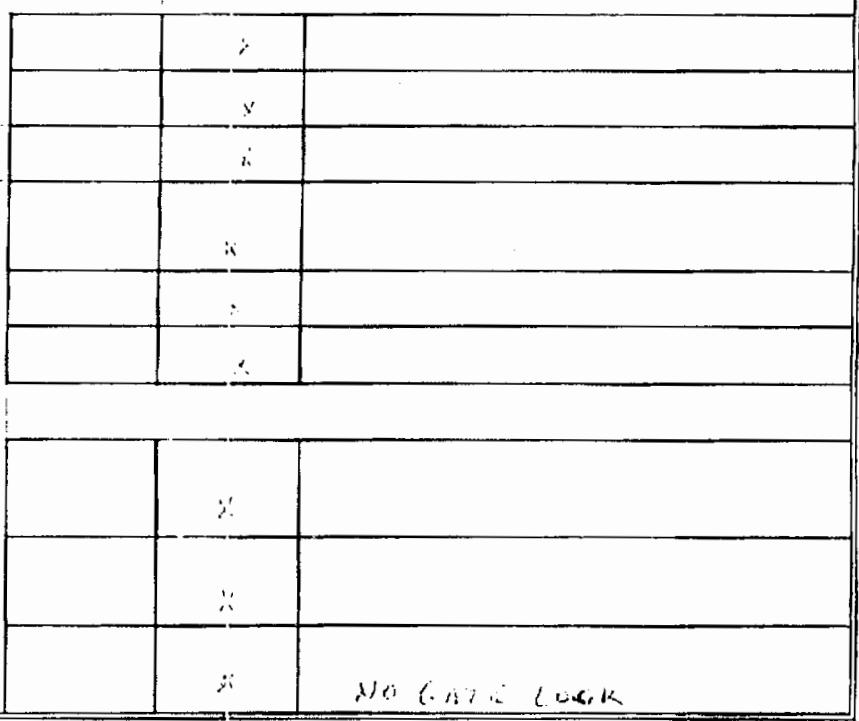




\section{CAU 404: ROLLER COASTER LAGOONS \& N. DISPOSAL TRENCH, POST-CLOSURE MONITORING CHECKLIST}

3. Waste Unil cover

a. Is there cvilence of settling?"

b. Is there crackinge?

c. Is there evidence of erosion around the cap (wind or water)?

d. Is there cvidence of animal hurrowing?

Ł. Have tle site markers been disturbed by man or malural processiss?

f. Do matural processes threnten to integrity of any cover or site marker!'

g. Ouler'?

\begin{tabular}{|c|c|c|}
\hline YES & $\mathrm{NO}$ & EXPLANATION \\
\hline & $\therefore$ & \\
\hline & $\therefore$ & \\
\hline & $\therefore$ & \\
\hline$\lambda$ & & 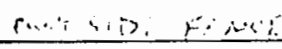 \\
\hline & $\therefore$ & \\
\hline & $\because$ & \\
\hline & & wia \\
\hline
\end{tabular}

4. Vegeialisc cover

a. Is perineter fence or mesh lencing denmaged?

b. Is there evidence of horses or rabbits on site"?

c. Is urganic mulcl adequate to prevent crosion?

d. Are weedy amual plants present"? If yes, are they a problem?

c. Are secded plant species lound on site"?

1. Is llore cuideuce of plant mortality'?

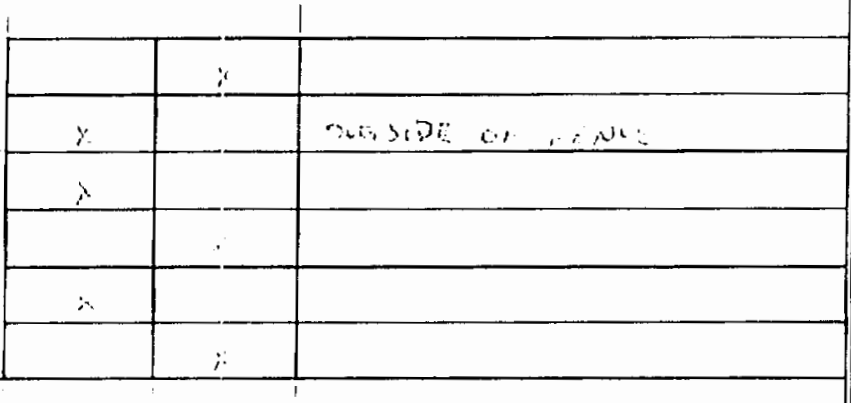

5 Photulocumtentation

a. Jas a photo log becu prepared?

c. Number of photos cxposed ( 1$)$

\section{FIELD CONCLUSIONS}

1. Is there an immincm hizard to the integrity of the unit? (mmediate report requircel)

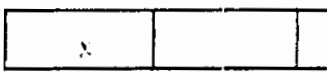

Marson/Agency to whom report made:

2. Are nore frecitent inspections required?"

3. Ne existimg maintenance/repair actions satlisfactory?

4. Is onher mainteniutedrepair necessity?

5. Is current shatus/cnndition of vegelative cover satisfactory?

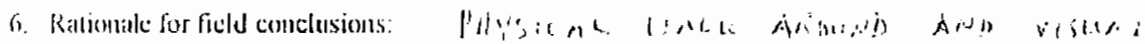

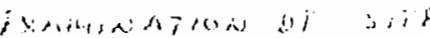

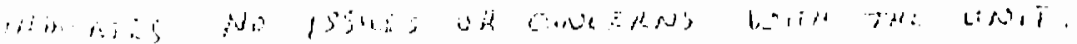

\section{E. CERTIFICATION}

Thave conducted an iespection of the Rolic Conster Sewage Lagoons \& Norh Disposal T'rench, CALJ 404. at the T"TR in accordance with the Post-

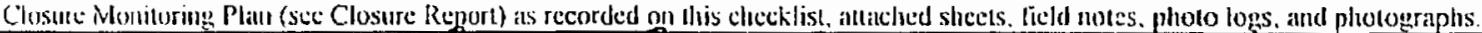

Chiel Inspector's Sigmatrice:

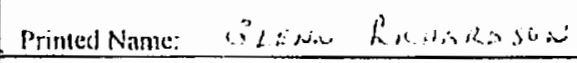

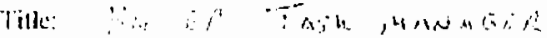

$$
\text { Dale: } \quad 5 / 9 / 20 \times 6 \text {. }
$$




\section{CAU 404: ROLLER COASTER LAGOONS \& N. DISPOSAL TRENCH, POST-CLOSURE MONITORING CIECKLIST}

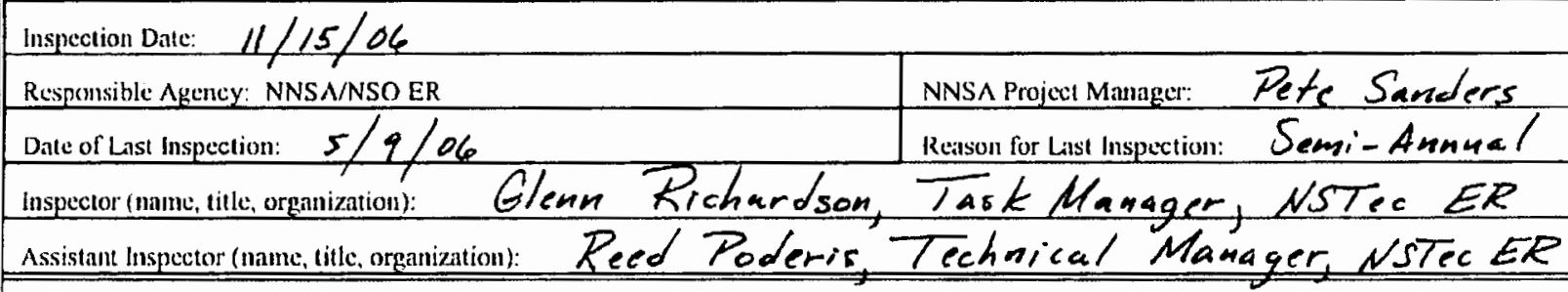

A. GENERAL INSTRUCTIONS

1. All checklist items must be completed and detailed comments made to document the results of the site inspection. The completed checklist is part of the lield record of the inspeetion. Additional pages should he used as neecssury to ensure that as complete record is provided. Attach line iulditional pages and number all pages upon eompletion of the inspection.

2. Any checklist line item matked by an inspector in a SHADED BOX, must be fully explained or an appropriate reference to previous reports provided. The purpose of this requirement is to provide a written explanation of inspector observations and the inspector's mationate lor conclusions and recommendations. Explanilions are lo be placed on additional altaclinents and eross-referenced appropriately. Explanations. in addition to namrative, will take the form of sketches, measurements, and annotated site maps.

3. The site inspection is a walking inspection of the entire sile including the periencler and sufficient imnsects to be able fo examine the entire surtace and all features specilically described in the cliecklist.

4. A stundard set of color $35 \mathrm{~mm}$ photographs (or eyuivalent) is required. In addition. all anomalens features or new features (such as changes in iddjatent area land use) are to be pholographed. $A$ ploto log entry will be made for easch pholograph takent.

5. This unit will be inspected biannually with formal reporting to the Nevada Division of Environmental Protection to be done annually. The annual report will inelude an execulive sumnury, this inspection checklist will, field notes and ploto log attached, and recommendations and conclusions.

\begin{tabular}{|c|c|c|c|c|}
\hline \multicolumn{2}{|r|}{ B. PREPARATION (To be completed prior to sile visit) } & YES & NO & EXPLANATION \\
\hline \multicolumn{2}{|r|}{ 1. Site as-huilt plans and site base map reviewed. } & $x$ & & \\
\hline \multicolumn{2}{|r|}{ 2. Previous inspection repons revicwed. } & $x$ & & \\
\hline \multirow{2}{*}{\multicolumn{2}{|c|}{ a. Were anomalies or trends delected on previous inspections? }} & & $x$ & \\
\hline & & & $x$ & \\
\hline \multicolumn{2}{|r|}{ 3. Site maintenance and repair records reviewed. } & $x$ & & \\
\hline \multirow{2}{*}{\multicolumn{2}{|c|}{$\begin{array}{l}\text { a. Has site repair resulted in a chunge from as-built conditions:? } \\
\text { b. Are revised as-bnilts available that reflect repair changes? }\end{array}$}} & & $X$ & \\
\hline & & & $y$ & $N / A$ \\
\hline \multicolumn{2}{|r|}{ C. STTE INSI'ECTION (To be completed during inspection) } & YES & NO & EXPLANATION \\
\hline
\end{tabular}

1. Adjacent olf-sile features widtin witershed areils.
a. Have there been any changes in use of adjacent area"
b. Are there any new roads or trails?
c. Has there been a change in the position of nearby washes"? d. Has there been lateral excursion or erosion/deposition of nearby
washes?
c. Are there new drainage channals?
r. Chinge in surrounding vegetation?

\begin{tabular}{|l|l|l|}
\hline & $x$ & \\
\hline & $x$ & \\
\hline & $x$ & \\
\hline & $x$ & \\
\hline & $x$ & \\
\hline & $x$ & \\
\hline
\end{tabular}

2. Security fence, signs.

J. Displacement of lenees. sile markers, boundary markers, or monuments?

b. Have any signs been danaged or removel? (Number of signs replaced:

c. Were gates locked?

\begin{tabular}{|l|l|l|}
\hline & $x$ & \\
\hline & $x$ & \\
\hline & & Notrequired. \\
\hline
\end{tabular}




\section{CAU 404: ROLLER COASTER LAGOONS \& N. DISPOSAL TRENCH, POST-CLOSURE MONITORING CHECKLIST}

3. Waste Unil cover

a. Is there evidence of setting?

b. Is thene cratcking'?

c. Is there evidence of erosion around the cap (wind or water)?

(l. Is there evidence ot animal burrowing?

e. Have the site markers been disturbed by man or natural processes?

f. Do natural processes threaten to integrity of any cover or site marker'?

g. Other'?

\begin{tabular}{|c|c|l|}
\hline YES & NO & EXPLANATION \\
\hline & $x$ & \\
\hline & $x$ & \\
\hline & $x$ & \\
\hline & $x$ & \\
\hline & $x$ & \\
\hline & $x$ & \\
\hline & $x$ & \\
\hline
\end{tabular}

4. Vegetalive cover

a. Is perimeter fence or mesh fencing damaged?

b. Is there evidence of harses or rabbits nn sile?

c. Is organic mulch adecutate to prevent erosion?

1. Are weedy anmual plants present? If yes, are they a problem?

c. Are seeded plant species found on site"?

f. Is there evidence of plant mortality?

\begin{tabular}{|l|l|l|}
\hline & $X$ & \\
\hline & $X$ & \\
\hline$X$ & & \\
\hline$X$ & & $\begin{array}{l}\text { weer } \\
\text { problemunal Plants ure nota }\end{array}$ \\
\hline$X$ & & \\
\hline & $X$ & \\
\hline
\end{tabular}

5. P'holo Documentation

a. Has a photo log been prepared"?

c. Number of pholos exposed ( 11

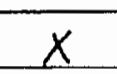

\section{FIELD CONCLUSIONS}

1. Is there an imminent layard to the integrity of the unit? (Immediate report required)

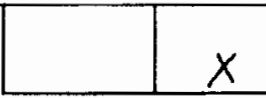

Pcrson/Agency to whom report made:

2. Are more frequent inspections requirext?

3. Are existing maintenanec/repair actions satisfactory?

4. Is other maintenance/repair necessary?

5. Is current status/condition of vegetative cover satislactory?

6. Rutionale for licld conclusions: The cover, fencing, and signage are in good comation. Vegetation sm the cover appeared to be in gaod comolition. was mo evidence of amimal burrows at the site.

\section{E. CERTIFICATION}

I have conducted an inspection of the Roller Coaster Sewage Lagoons \& North Disposal Trench, CAU 404, at the TTR in aceordinee with the PostClosure Monitoring Plan (sec Closure Report) as recorded on this checklist. altiched sheets, field notes, phnto logs, amd photographs.

Clice Inspector's Signature: Printed Nimne: Glean Fichardson

ritle:

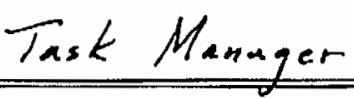

Date: 


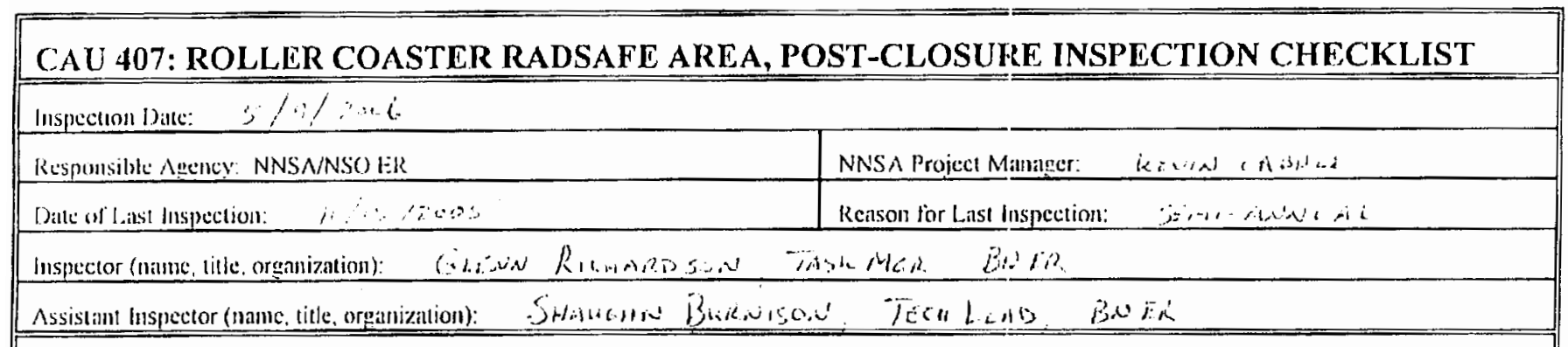

\section{A. GENERAL INSTIRUCIIONS}

1. All chechlist itums must be completed and detailed comments made lo document the resilts of the site inspection. The completed checklist is part of the lield reeord of the inspection. Additional paiges slould be used as necessary to ensure that it complete record is provided. Altach the addisional pagkes inld muber all pages upon completion of the inspection.

2. Any checklist line item marked by an inspector in al SIIADED BOX. must be fully explained or ant appropriate reterence to previous reports provided. The purpose of this recuirement is lo provide a written explanation of inspecter observaltions and the inspector's rationale tor conchusions and recommendations. Explanations are to be placed on additional attacilments and cross-refercncerl appropriacely.

lixplantations, in addition to narrative, will talke the form of sketehes, measurements, and annotated sike maps.

3. The site inspection is a walkiens inspectinn of the entire site including lle perimeter and sufficicut transects to be athle to examine the conire surtine and all lentures specilically deseribed in the checklist.

4. $\Lambda$ standard set of color $35 \mathrm{~mm}$ photographs (or equivalent) is required. In addition, all a mamalous leatures or new features (suel as changes in adjacent area land use) are to be plotograpled. $\wedge$ photo loge ents will be made for cach photograph taken.

5. This unit will he inspected biamually with formal reporting to the Nevada Division of Environmembal Protection to be done anmoally: The

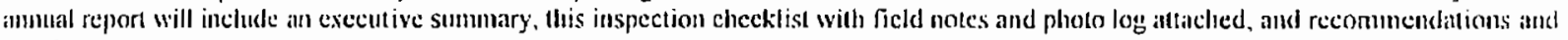
conclusions.

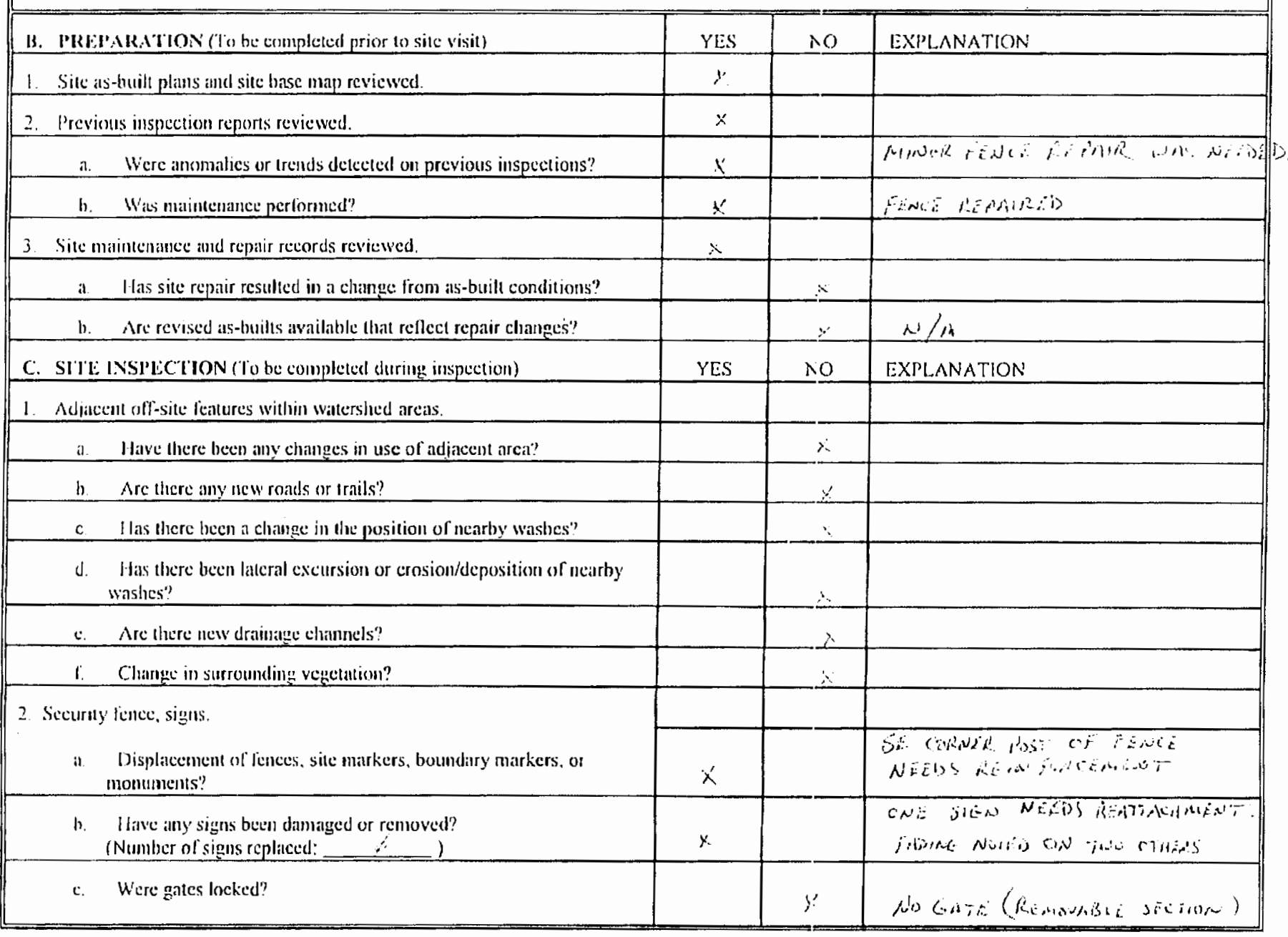




\section{CAU 407: ROLLER COASTER RADSAFE AREA, POST-CLOSURE INSPECTION CHECKLIST}

3. Waste Unit cover.

a. is there evidence of setaling?

h. Is llice critcking?

c. Is there cridence of crosion around lac cinp (wind or walter)?

d. Is there cvidence of animal hurrowinge?

c. Do natural processes threalen to inlegrity of any cover or sitc marker?

i. Oolher?

4. Vegetalive cover.

a. Is perimeter fence or mesh fencing damaged?

b. Is there evilence of horses or rabbits on site?

c. is organic mulch andequate to prevent crosion?

d. Are wecdy ammal plants presciu? If ycs, are they a problem?

c. Are seeded plant species found on site?

i. Is there evidence of plant mortality?

\begin{tabular}{|c|c|c|}
\hline YES & $\mathrm{NO}$ & EXPLANATION \\
\hline & $x$ & \\
\hline & $\therefore$ & \\
\hline & $\because$ & \\
\hline$x$ & & 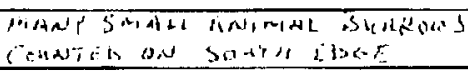 \\
\hline & $\because$ & \\
\hline & & \\
\hline
\end{tabular}

5. Photo Documentation

a. Las a photo log been prepared?

\begin{tabular}{|c|c|c|}
\hline$\underline{x}$ & & 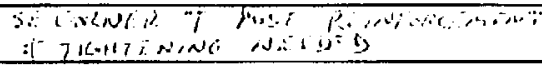 \\
\hline$x$ & & 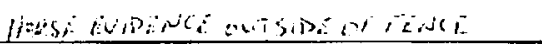 \\
\hline$x$ & & 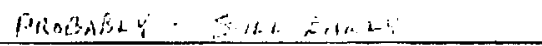 \\
\hline & $\underline{m}$ & \\
\hline$x$ & & 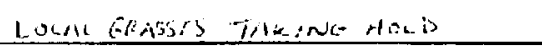 \\
\hline & $-x$ & \\
\hline
\end{tabular}

$x$

c. Number of photos exposed ( 2 )

\section{HIELID CONCLLSIONS}

1. Is there an inminent hazard to the intenrity of the unit? (Immediate report required

Person/Agency lo whom report made:

2. Are more frequent inspections required"

3. Are cxisting maintenance/repair actions satistactory?

1. Is other maintenance/repair neccssary?

5 Is current status/condition of vegetalive cover saltisfactory?

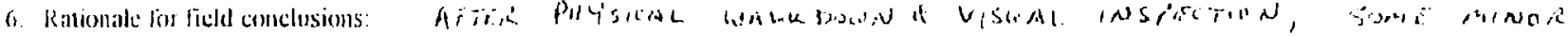

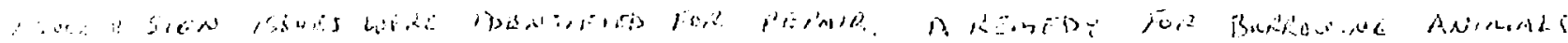

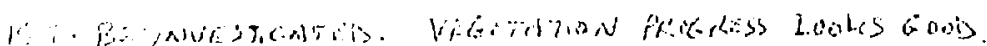

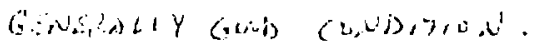

\section{E. CERTIIICITION}

I have conducted an inspection of the Roller Conster RadSafie Area, CAU 407, at the TTR in accordance with the Prost-Closure Monitoring Plan (see Closure Report) as recorded on this cleecklist, attached sliects, field notes, photo logs, and plotographlss.

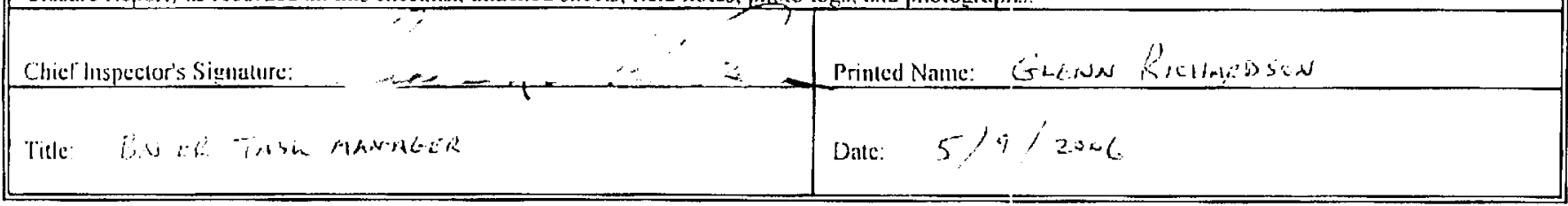




\section{CAU 407: ROLLER COASTER RADSAFE AREA, POST-CLOSURE INSPECTION CHECKLIST}

Inspection Date: $\quad 11 / 15 / 06$

Responsible Agency: NNSANSO ER

Datc of Last Inspection: $5 / 9 / 06$

Inspector (nance, litle, organization):

Gleenn Richandson, NNSA Project Manager: Pete Sanders

Rcason for Last Inspection: Semi-Annual

Assistant inspector (name. title. organization): Reed Poderis, Technical Manager, NSTei ER

A. GENERAL INSTRUCTIONS

1. All eluecklist items must be eompleted and detailed comments made to document the results of the site inspection. The completed checklist is part of the field recond of the inspection. Adelitional pages should be used as necessary lo ensure that a complete record is provided. Altael the additional pages and mumber all pages upon completion of the inspection.

2. Any checklist fine item marked by an inspector in a SHADED BOX. must be lully explained or an appropriate reference te previous reports provided. The purpose of this requirement is to provide a written explanation of inspector observations and the inspector's rationale for conclusions and recommendations. Explanations are to be placed on additional attacluments and cross-referenced appropriately. Explanations, in addition to narrative, will take the form of sketches, meilsurenents, and annotated site maps.

3. The site inspection is it walking inspection of the entire site including the perimeter and suflicient transects to be able to examine the centire surface and all leatures specifically described in the checklist.

4. A standard set of color $35 \mathrm{~mm}$ photographs (or cquivalent) is required. In addition, all anomalous fiealures or new features (such as changes in adjacent area land use) are to be photographed. A photo log entry will be made for cach photograph taken.

5. This unit will be inspected bianoually with formul reporting ot the Nevada Division of Environmental Protection to be done annually. The annual report will include an executive summary, this inspection cliceklist with ficld notes and photo log altached, and recommendations and conclusions

\begin{tabular}{|c|c|c|c|}
\hline B. PREPARATION (To be completed prior to site visit) & YES & NO & EXPLANATION \\
\hline 1. Sitc as-built pians and site base nap revicwed. & $\lambda$ & & \\
\hline 2. Previous inspection teports reviewed. & $x$ & & \\
\hline a. Were anomalies or trendi detected om previous inspections? & & $x$ & \\
\hline b. Was maintenance performed? & $x$ & $\theta^{m R}$ & $\begin{array}{l}\text { Masurtenance was performed in } \\
\text { Jine } 2006 \text {. }\end{array}$ \\
\hline 3. Site maintenance and repair reconds reviewed. & $x$ & & \\
\hline al Has site repair resulted in a change from as-built conditions? & & $x$ & \\
\hline b. Are revised as-builts available that reflect repair clanges"? & & & $N / A$ \\
\hline C. SITE INSPECTION (To be completed during inspection) & YES & NO & EXPLANATION \\
\hline 1. Adjacent off-site features within watershed areis. & & $x$ & \\
\hline a. Have there been any changes in use of adjaccat area? & & $x$ & \\
\hline b. Are there any new roads or trails? & & $x$ & \\
\hline c. Has there been a change in the position of nearby washes? & & $x$ & \\
\hline $\begin{array}{l}\text { d. Has there been lateral excursion or erosion/deposition of nearby } \\
\text { washes? }\end{array}$ & & $x$ & \\
\hline c. Are there new drainage clannels? & & $x$ & \\
\hline \&. Claange in surrounding vegetation? & & $x$ & \\
\hline \multicolumn{4}{|l|}{ 2. Security rence. signs. } \\
\hline $\begin{array}{l}\text { a. Displacement of fences, sile markers, boundary matkers. or } \\
\text { monuments? }\end{array}$ & & $x$ & \\
\hline $\begin{array}{l}\text { b. Have any signs been damaged or removed"? } \\
\text { (Number of signs replaced: }\end{array}$ & & $x$ & \\
\hline c. Were gates lucked? & & & $N / 4$ \\
\hline
\end{tabular}




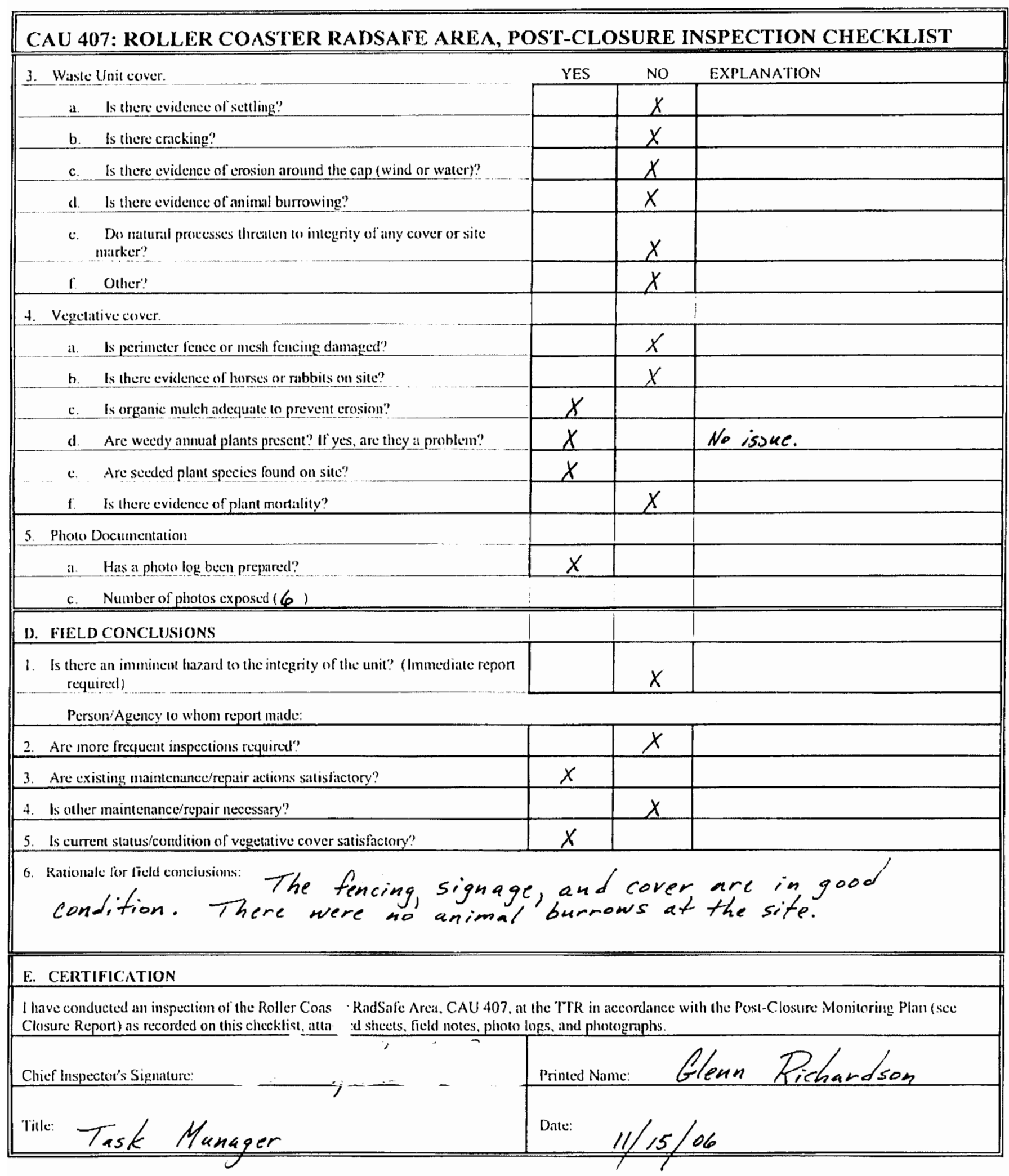




\section{CAU 423: AREA 3 UNDERGROUND DISCHARGE POINT,}

POST-CLOSURE INSPECTION CHECKLIST

Inspection Dane: $5 / \% / 2 m 6$

Responsible Aecacy: NNSANSO ERR

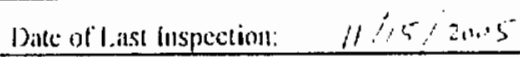

NNSA Project Manager: KeÉN Cosing

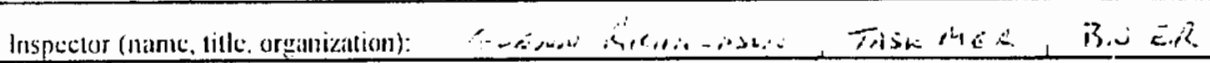

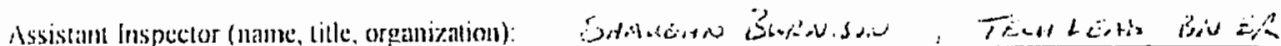

\section{A. GENERAL INSTRUCTIONS}

1. All checklist itcms must be completed and detailed comments made to document the results of the site inspection. The completed clecelist is part of the field record of the iuspection. Additional pages should be used as necessiary to colsure that a complete record is provided. Antach the additional pilges ant number all pages upon completion of the inspection.

2. Any chechist line ilem marked by an inspector in a SIIADED BOX, must be fully explained or an appropriale reference to previous reports provided. The purpose of this recuirement is to provide a written explantition ol inspector observations and alle inspector's rationtale for conclusions and recommendations. Explanations are in be placed on additional allaclunents and eross-referenced appropriately:

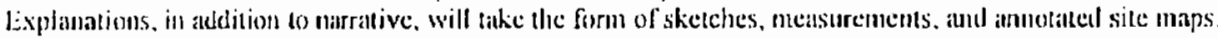

3. The sile inspection is a walking inspection of the entirc sile including the perimeter and sufficient tratsects to be able to examine the cntire surliace and all fentures specilically described in the chectlist.

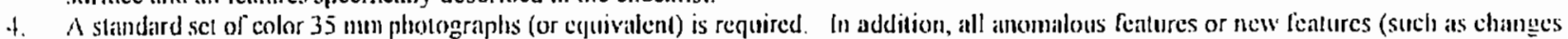
in adjacent area land use) are to be pholographed. A photo log entry will be makde for each photograph taken.

5. This unit will be iuspected biannually with formal reporting to the Nevada Division of Environnental Protection to be done anmually: The ammat report will include an execulive summiry, this inspection chectist with fiedd notss and photo leng attached, and recommendations and conclusions.

\begin{tabular}{|c|c|c|c|}
\hline B. PRLEPARATION' (To be completed prior in sile visit) & YFS & 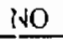 & EXPLANATION \\
\hline 1. Site as-buile platis and site batic map reviewed. & $\ddot{x}$ & & \\
\hline 2. Previous inspection reports reviewed. & s: & & \\
\hline a. Were anomalies or trends deteeded on previous inspections? & & $\therefore$ & \\
\hline b. Wils maintemance performed? & & $\ddot{x}$ & \\
\hline 3. Sile mainentiance ind repair records reviewed. & 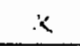 & & \\
\hline a. Has site repair resuled in a clange from as-buill conditions"? & & $\checkmark$ & \\
\hline b. Are revised as-builts available that reflect repair changes? & & & $\therefore A$ \\
\hline C. SITE INSPECTION (la be completed during inspection) & YES & 140 & EXPLANATION \\
\hline 1. Adjaceou oft-site features willin watershed areas. & & & \\
\hline a. Have lhere been any changes in use of adjacent area? & & $\lambda$ & \\
\hline b. Are there any new ronds or trills"? & & $x$ & \\
\hline c. Ifas there been a change in the position of nearby washes? & & $\therefore$ & \\
\hline $\begin{array}{l}\text { d. Ilas there heen tatcral excursion or crosion/deposition of nearby } \\
\text { waslues? }\end{array}$ & & ; & \\
\hline e. Are there new drainage clamuets? & & $x$ & \\
\hline 1. Change in surrounding vegetalion? & & $\therefore$ & \\
\hline Security lenes, signs. & & & \\
\hline a. Displacement of site markers, boundary markers, or monuments? & & $x$ & \\
\hline $\begin{array}{l}\text { h. Ilave any sigus becen diandaged or removed? } \\
\text { (Number of signs replaced: }\end{array}$ & & x & \\
\hline
\end{tabular}




\section{CAU 423: AREA 3 UNDERGROUND DISCHARGE POINT, POST-CLOSURE INSPECTION CHECKIJIST}

3. UsL Restrictud Arew:

a. Is there evidence of scelling?

b. Is there crachinge!

c. Is there evidence of erosion (wind or water)?

a. Is there evidence ol animal burrowing"?

c. I live line site markets been disturbed by man or natural processes?

f. Is there vergelation in the area?

2. Do matural processes thrtaten to inlegrity of any cover or site markele?

lt. Olher?

\begin{tabular}{|c|c|c|}
\hline YES & NO & EXPLANATION \\
\hline & $\lambda$ & \\
\hline & $x$ & \\
\hline & $x$ & \\
\hline & $\underline{x}$ & \\
\hline & $\ddot{x}$ & \\
\hline & $x$ & \\
\hline & $x$ & 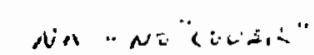 \\
\hline
\end{tabular}

4. Pholo Documentation

a. Has a photo log been preprared!! $x$

b. Number of photos exposed (3)

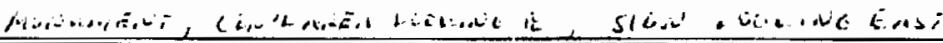

\section{IIELDCONCLUSIONS}

1. Is there an immincul haralod to the integrity of the unit? (Immediate report required)

\section{$x$}

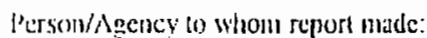

2. Are more freplacm inspections required?

3. Are existing maintenancs/repair actions satistactory?

4. Is ofler maintenance/repair necessant?

5. Is current status/condition of the sitc salisfactory"
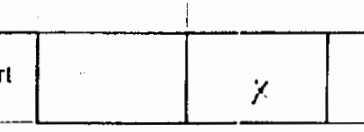

6. Rallimalc for ficld conclusions:

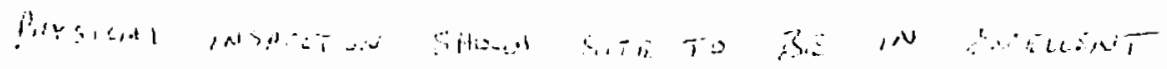

$$
\begin{aligned}
& (a, i), r, \pm, j \text {. }
\end{aligned}
$$

\section{E. CERTIFICATION}

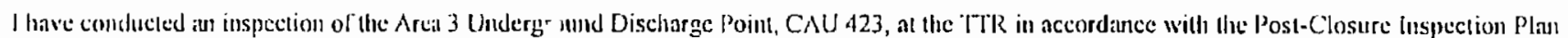
(see Closure Report) as recorded on this clecklist. a jicd sheets, Field notes, photo logs, and pliolographs.

"hicl hispector's Signtuture:

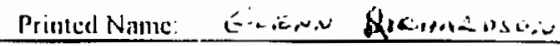

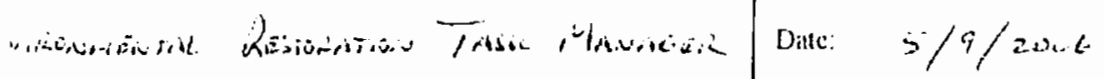




\section{CAU 423: AREA 3 UNDERGROUND DISCIIARGE POINT, POST-CLOSURE INSPECTION CHECKLIST}

\begin{tabular}{|c|c|}
\hline \multicolumn{2}{|l|}{ Inspection Dalc: $\quad 11 / 15 / 04$} \\
\hline Responsible Agency: NNSANSO ER & NNSA Project Manager: Pete Sanders \\
\hline Date of Last Inspection: $\quad 5 / 9 / 06$ & Reason for Last inspection: Semi- Alemeat \\
\hline Inspector (name, titlc, organization): & Manayer NSTee LE \\
\hline
\end{tabular}

A. GENERAL INSTRUCTIONS

1. All checklist items must be completed and detailed comments made to document the results of the site inspection. The completed cheeklist is part of the licld recorel of the inspection. Additional pages should be used as necessary to ensure that a conplete record is provided. Attach the additional pages and number all pages upon completion of the inspection

2. Any checklist line ilem marked by an inspector in a SHADED BOX, must be fully explained or an appropriate referenee to previous reports provided. The purpose of this requirement is to provide a wrilten explanation of inspector observations and the inspector's rationale for conclusions and recomnendations. Explanations are to be placed on additional attacluments and eross-referenced appropriately.

Explanations, in addition to narrative, will take the forn of sketches, meisurements, and annotaled site malps.

3. The site inspection is at watking inspection of the entire site including the perimeter and suflicient transects to be able to examine the entire surface and all features specifienlly described in the checklist.

4. A standard set of color $35 \mathrm{~mm}$ photograpiss (or equivalent) is required. Ini addition, all anomalous features or nesv features (such as changes itl adjacent area land use) are to be pholographed. A photo log entry will be made for ench photograph taketr.

5. This unit will be inspected bianually with formal reporting to the Nevada Division of Environmentat Prolection to be done annually. The annual report will include an execulive summary, this inspection checklist will field notes and photo log altached, and recommendations and conclusions

\begin{tabular}{|c|c|c|c|}
\hline B. PREPARATION (To be completed prior to site visil) & YES & NO & EXPLANATION \\
\hline 1. Site as-built plans and sile base map reviewed. & $x$ & & \\
\hline \multicolumn{4}{|l|}{ 2. Previous inspeclion reports revicwed. } \\
\hline a. Were anomalies or trends delected on previous inspections? & & $x$ & \\
\hline b. Wiss maintenance performed? & & $x$ & \\
\hline 3. Sile maintenance and repair records reviewed. & & & $N / A$ \\
\hline a. Has site repair resulled in a change from as-built conditions? & & $x$ & \\
\hline b. Are revised as-builts available that reflect repair changes? & & & $N / A$ \\
\hline C. SITE INSPECTION (To be completed during inspeetion) & YES & NO & EXPLANATION \\
\hline \multicolumn{4}{|l|}{ 1. Adjacent off-sile fealures witlsin waltershed areas. } \\
\hline a. Have there been any chamges in use of adjacent areal? & & $x$ & \\
\hline b. Are there any new roads or trails? & & $x$ & \\
\hline c. Has there been a clange in the posidion of nearby washes? & & $x$ & \\
\hline $\begin{array}{l}\text { d. Has there been katcral excursion or erosion/deposition ol nearby } \\
\text { washes? }\end{array}$ & & $X$ & \\
\hline e. Are lhere new drainage chanmels? & & $X$ & \\
\hline f. Change in surrounding vegetation? & & $X$ & \\
\hline \multicolumn{4}{|l|}{ 2. Security fence, signs, } \\
\hline il. Displacement of site markers, houndary markers, or monuments? & & $\chi$ & \\
\hline $\begin{array}{l}\text { b. Have any signs been danaged or removed"? } \\
\text { (Number of signs replaced: } \$ \text {. }\end{array}$ & & $X$ & \\
\hline
\end{tabular}




\section{CAU 423: AREA 3 UNDERGROUND DISCHARGE POIN'I, POST-CLOSURE INSPECTION CHECKLIST}

3. Use Restricled Area:

a. Is there evidenec of settling?"

b. Is there cracking!

c. Is there evidence of erosion (wind or water)?

d. Is there evidence of aminal burrowing?

c. Have the site markers been disturbed by inan or natural processes?

f. Is there vegetation in the ares?

g. Do natural processcs threnten to integrily of anny cover or site marker?

li. Olher?

\begin{tabular}{|c|c|c|}
\hline YES & NO & EXPLANATION \\
\hline & $x$ & \\
\hline & $x$ & \\
\hline & $x$ & \\
\hline & $x$ & \\
\hline & $x$ & \\
\hline & $\not$ & \\
\hline & $x$ & \\
\hline & $x$ & \\
\hline
\end{tabular}

4. Photo Documentation

a. Ilas a photo log been prepared?

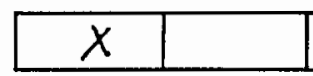

b. Number of photos exposed ( L)

\section{FIELD CONCLUSIONS}

1. Is there an imminent hazard to the integrity of the unit? (Immediate report required)

Person/Agency to whom report mate:

2. Are more frequent inspections requirod?

3. Are cxisting maintenance/repair actions siatisfactory?

4. Is other maintemancelrepair necessary?

5. Is current stilusicondition of the sile satisfactory?

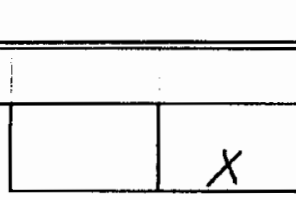

6. Rationale lor ficld conclusions: General site condifions are goad. A waste oil line that runs to the Undergrosed Discharge Point will be removed or closedin place as a best management practice. Per NNSA direction, this is planned in ENoT.

\section{E. CERTIFICA'TION}

I have conducted an inspection of the Area 3 Underground Disct- Point, CAU 423, at the TTR in accurdance with the Post-Closure Inspection Phan (see Closure Report) as recorded on this checklist, altached sle" ield notes, photo logs. and photographs.

Chict Inspector's Signature: , -1 Printed Niume:

Glemn Pichamdson

Title: Task Maneger

Datc:

$11 / 15 / 06$ 


\section{CAU 424: AREA 3 LANDFILL COMPLEX, POST-CLOSURE INSPECTION CHECKLIST}

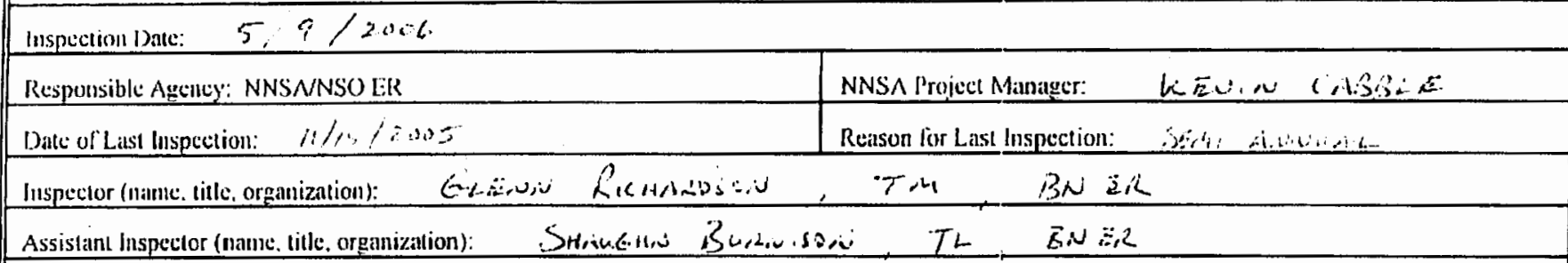

\section{A. GENERAL INSTRUCTIONS}

1. All clecklist items must be compleled and detiiled comments mate to document the results of the sile inspection. The completed checklist is part of the tield record of the inspection. Additional pages should be used as necessary to consure that a complete record is provided. Allated the additional pages and number all pages upon completion of the inspection.

2. Any checklist line itcm marked by an inspector in a SHADED BOX, must be fully explained or an appropriate relerence to previous reports provided. The purpose of this recuircment is to provide a written explimation of inspector observations and the inspectur's rationale fnr conchusions and recommendations. Explanations are to be plated on additional altachnents and cross-referenced approprialcly: Explanations, in addition to narrative, will take the form ol sketches, measurements, and annotaled site maps.

3. The site inspection is a walkiug insplection of the entire site incleding the perimeter and suffecient transcels to be able to examine the entire surlace and all lealures specifically described in the chechlist.

4. A standard set of color $35 \mathrm{~mm}$ photographs (or equivalent) is required. In addition, all amomalous features or new features (such as changes in adjacent aren land use) are to be photographed. $\wedge$ photo log entry will be made for exich photograph takects.

5. This unit will be inspected bianually with formal reporting to the Nevada Division of Enviromenental Protection to be donte anmually: The anmual report will inelude an execulive summary, this insp̧ection cluecklist with lield notes and photo log attacled, and recommendations and conclusions.

\begin{tabular}{|c|c|c|c|}
\hline B. PREP'ARATION (To be complated prior to site visit) & YES & NO & EXPLANATION \\
\hline 1. Sitc as-built plans and silc base map revicwed. & $\kappa$ & & \\
\hline 2. Previous inspection reporss reviewed. & $x$ & & \\
\hline a. Were anomalics or trends delecied on previous inspections? & & $\therefore$ & \\
\hline b. Was maintcuatuce performed!? & & $\lambda$ & \\
\hline 3. Sitc maintenance and repair records reviesved. & 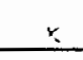 & & \\
\hline a. Has site repair resulted in a change from as-built conditions? & & $x$ & in \\
\hline b. Are revised as-buills avaihable that rellect repair chameges? & & & $\therefore$ \\
\hline C. SITE INSPECTION (To be completed during inspection) & YES & NO & EXPLANATION \\
\hline 1. Adjacent oft-site teatures willin watershed areas. & & & \\
\hline it. Have linese been any changes in use of aljiacent areal? & & $x$ & \\
\hline b. Are there any new roads or trails? & & 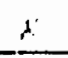 & \\
\hline c. Has there been a change in the position of nearby washes? & & $\therefore$ & \\
\hline $\begin{array}{l}\text { d. Has there been tateral cxcursion or erosion/deposition of ncarby } \\
\text { wasthes? }\end{array}$ & & 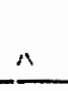 & \\
\hline c. Are there new drainage clanumels? & & $\therefore$ & \\
\hline 1. Change in surrounding vegetilion? & & $\therefore$ & \\
\hline \multicolumn{4}{|l|}{ 2. Securily fence, signs. } \\
\hline $\begin{array}{l}\text { a. Displacement of fences, sile mirkers, boundary markers, or } \\
\text { momuments" }\end{array}$ & & $\because$ & \\
\hline $\begin{array}{l}\text { b. Have iny sigus been daunaged or removed" } \\
\text { (Number of signs replaced: }\end{array}$ & & $\therefore$ & \\
\hline c. Were gates locked"? & & & $\therefore A$ \\
\hline
\end{tabular}




\section{CAU 424: AREA 3 LANDFILL COMPLEX, POST-CLOSURE INSPECTION CHECKLIST}

3. Waste Unit cover.

a. Is there evidenec of seteling?

b. Is there cracting?

c. Is there evidence of crosion around the cap (wind or water)?

d. Is there evidence of animal burrowing"?

c. Have the site markers been disturbed by man or natural processes"s?

f. is the vegetation on the cover?

@. Do nittural processes threaten to integrity of any cover or site markicr?"

I. Ollicr?

\begin{tabular}{|l|c|l|}
\hline YES & NO & EXPLANATION \\
\hline & $\ddots$ & \\
\hline & $\mu$ & \\
\hline & $\kappa$ & \\
\hline & 1 & \\
\hline & $\therefore$ & \\
\hline & $\therefore$ & NA \\
\hline & $\therefore$ & \\
\hline & & ivi \\
\hline
\end{tabular}

t. Phno Documentation

a. Ilas a photo log beeu prepared?

c. Number of photos exposed ( )

\section{FIELD CONCLUSIONS}

1. Is these an imminent hazard to the integrity of the tuit? (hmonedinte report required)

PersonlAgency to whom report made:

2. Are more ficouent inspections required"?

3. Are existing mainenunce/repair actions sutis/actory?

4. Is wher mainlenamecirepair necessary?

5. Is cursent status/condition of vegetative cover sattisfactory?

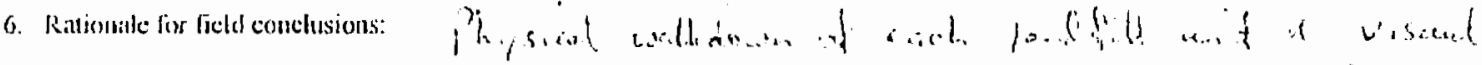

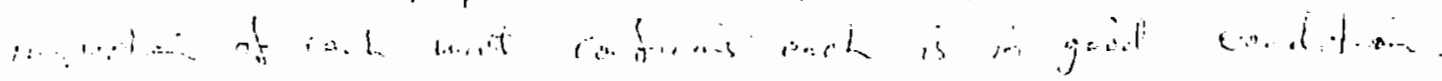

\section{CHRIFICATION}

1 have condenced an inspection of the Area 3 Landfill Complex, CAU 424, at the TTR in accordance with the Post-Closure hispection Plan (see Closure Repurt\} is recorded on this checklist. autacled shects. field notes, photo logs. and photographls.

Chic Insijector's Sigualure:

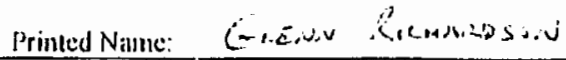

Tille: LR, Thin thes

Datc: $\quad 5 / 9 / 2.606$ 
CAU 424: AREA 3 LANDFILL COMPLEX, POST-CLOSURE INSPECTION CHECKLIST Inspection Date: $\quad 1 / / 15 / 06$

Responsible Agency: NNSANSO ER

Date of Last Inspection: $5 / 9 / 06$

Inspector (name, title, organization): Glenn Pichardson, Task Maneger, NSTec ER

Assistant Inspector (name, tille, organization)

A. GENERAL INSTRUCTIONS

1. All checklist items must be completed and detailed comments made to document the results of the site inspection. The completed eheeklist is part of the field record of the inspection. Additional pages should be used as necessary to ensure that a complete record is provided. Attact the additional pages and number all pages upon completion of the inspection.

2. Any cheeklist line item marked by an inspector in a SHADED BOX. must be fully exphined or an appropriate reference to previons reports provided. The purpose of this requirement is to provide a written explanation of inspector observations and the inspector's rationale for conclusions and reconmendations. Explanations are to be placed on additional attachunents and cross-referenced appropriately.

Explanations, in addition to mirrative, will take the form of sketches, measurements, and aunotated site maps.

3. The sitc inspection is a walking inspection of the centire site including the perimeter and suffieient tmansects to be abse to exantuie the entire surface and all features specifically described in the checklist.

4. A standarcl set of color $35 \mathrm{~mm}$ photograplss (or equivalent) is required. In addition, all anomalous features or new features (such as clanges in adjacent aren land use) are to be pholographed. A photo log entry will be made for cach phologmph taken.

5. This unit will be inspecterl biannually with formal reporting to the Nevada Division of Environmental Protection to be donc anusually. The annual report will include an executive summary, this inspection ehecklist with field notes and photo log nttached, and recommendations and conclusious.

\section{B. PREPARATION (To be completed prior to site visil)}

1. Sile as-built plans and site base map reviewed.

2. Previous inspection reports revicuved.

a. Were anomalies or trends delected on previous inspections?

b. Was unaintenance perfonmed?

3. Sitc maintenance and repair records reviewed.

a. Has site repair resulted in a change from as-built conditions?

b. Are revised as-builis available that reflect repair changes?

C. SITE INSPECTION (To be completed during inspection)

1. Adjacent off-sile features within watershed areas.

a. Have llere been any clanges in use of adjacent area?

b. Are there any new roads or trails?

c. Ilas there been a change in the posilion of nearby washes?

d. Has there been lateral excursion or crosion/deposition of nearby washes?

c. Are there ncw drainage channels?

i. Change in surrounding vegetation?

2. Sccurity fence, signs.

a. Displacement of fences, sitc unarkers, bountary markers, or mounuments?

b. Have any signs becil damaged or removed? (Number of signs replaced:

1

c. Were galtes locked?

\begin{tabular}{|c|c|c|l||}
\hline & YES & NO & EXPLANATION \\
\hline$X$ & & \\
\hline$X$ & & \\
\hline & $X$ & \\
\hline$X$ & $X$ & \\
\hline & $X$ & \\
\hline & $X$ & $N / A$ \\
\hline YES & NO & EXPLANATION \\
\hline & & $X$ & \\
\hline & $X$ & \\
\hline & $X$ & \\
\hline & $X$ & \\
\hline & $X$ & \\
\hline & $X$ & \\
\hline & & $X$ & $N / A$ \\
\hline
\end{tabular}


CAU 424: AREA 3 LANDFILL COMPLEX, POST-CLOSURE INSPECTION CHECKLIST

3. Waste Unit cover.

i. Is there evidence of settling?

b. Is there cracking?

c. Is there evidence of crosion around the cap (wind or water)?

d. Is there evidence of amimal burrowing?

e. Hnve the site markers becn disturbed by man or natural processes?

i. Is the vegetation on the cover?

g. Do natural processes threalen to integrity of any cover or site marker?

h. Other?

\begin{tabular}{|c|c|l|}
\hline YES & NO & EXPLANATION \\
\hline & $x$ & \\
\hline & $x$ & \\
\hline & $x$ & \\
\hline & $x$ & \\
\hline & $x$ & \\
\hline$X$ & $x^{\text {Br }}$ & \\
\hline & $x$ & \\
\hline & $x$ & \\
\hline
\end{tabular}

4. Photo Doeumentation

a. Has a photo log becen prepared?

c. Number of photos exposed ( /4)

\section{FIELD CONCLUSIONS}

1. Is there an imminent hazard to the integrity of the unit"? (linmediante repont required)

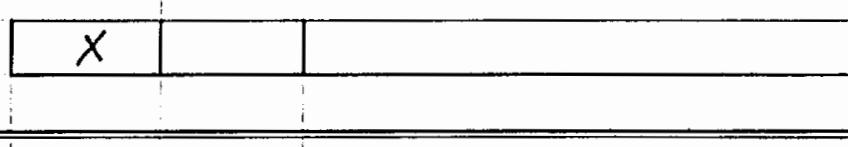

Person/Agency to whom report made:

2. Are more frecuent inspections rejuirecl?

3. Are existing maintenance/repair actions salisfactory?

4. Is other maintenance/repair necessiry?

5. Is current status/eondition of vegetative cover sntisfictory?

6. Rationale for lield conclusions: Overall site condifions are good. There was no damaze to the fencing or the veyetative covers.

\section{E. CERTIFICATION}

I have conducted an inspection of the Area 3 Landfill Complex. CAU 424, at the TTR in accordance vith the Post-Closure lnspection Plan (see Closure Repurt) as recorded on this checklist, athached sheets, field notes, photo hogs, and phohographs.

Chief Inspector's Signature:

Printed name: Glever Fichardson
Date: $\quad 1 / 15 / 06$




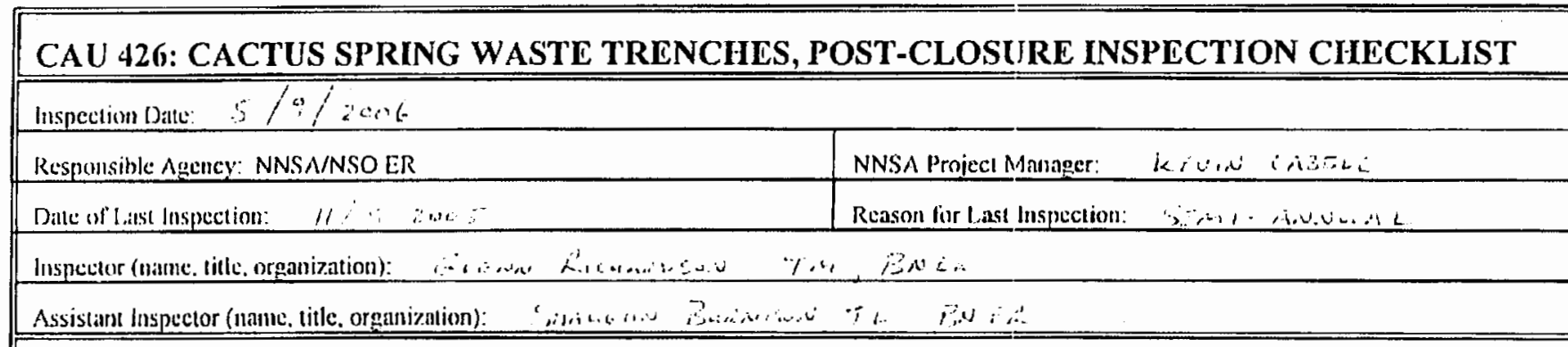

\section{A. GENERAI INSTRUCIIONS}

1. All checklist itcms must be completed and detailed comments nade to document the results of the site inspection. The completed checklist is part of the lield record of the inspection. Additional pages should be used as neecssary in ensure that a complete record is provided: Altiels Ule additional pages and number all pages upon completion of the inspection.

2. Any checklist line item marked by an inspector in a SHADED BOX, must be fully explained or an appropriate reference to previous reperts provided. The purpose of this requirement is to provide a written explanation of inspector observations and the inspector's rationale for conclusions and recommendations. Explanations are to be placed on additional attichnents and cross-referenced appropriately.

[Explamations, in iddition to narrative, will take the form of shetches, measurements, and imnotated site maps.

3. The site inspection is a walking inspection of the entire site including the perinteter and sufficient transects to be able to examine the entire surface and all features specilicilly described in the checklist.

4. A standard set of color 35 imm photographs (or equivalent) is required. In addition, all momalous features or new features (suclı as changes ill idjiacent areil land use) are to be photographed. A photo log cultry will be mide for cach photograph taken.

5. This unit will be inspected hianmually with formal reporting to the Nevada Division of Environmental Protection to be done anmually. The immual report will include an executive summirs; this inspection clecklist with field noles and photo log attached, and reconmendations and conclusions.

\begin{tabular}{|c|c|c|c|}
\hline B. PREPARATION (lo be completed prior to site visit) & YLS & NO & EXPLANATION \\
\hline 1. Site as-buill plans and site base map reviewed. & $\therefore$ & & \\
\hline \multicolumn{4}{|l|}{ 2. Previous inspectinn reports reviewed. } \\
\hline \multirow{2}{*}{$\begin{array}{l}\text { a. Were anomalies or trends delected on previous inspections? } \\
\text { h. Was maintenamce performed? }\end{array}$} & & $\therefore$ & \\
\hline & & $\therefore$ & \\
\hline \multirow{3}{*}{$\begin{array}{l}\text { 3. Site maintenance and repair records reviewcel. } \\
\text { a. Has site repair resulled in a change from as-built conditions? } \\
\text { b. Are revised as-builis available that rellect repair changes? }\end{array}$} & $\therefore$ & & \\
\hline & & $\because$ & \\
\hline & & & NA. \\
\hline C. SITE: INSPEC:IION (to be completed during inspection) & YES & INO & EXPL.ANATION \\
\hline \multicolumn{4}{|l|}{ 1. Adjacent ofl-site feitures within watershed areats. } \\
\hline a. Have there been any changes in use of adjacent aren? & & $\therefore$ & \\
\hline b. Are there any' new ronds or trails? & & $x$ & \\
\hline c. Ilas there been a change in the position of nearlyy washes? & & $\therefore$ & \\
\hline $\begin{array}{l}\text { d. Itas there been latteral excursion or erosion/deposition of nearby } \\
\text { wasines? }\end{array}$ & & $\because$ & \\
\hline ¿. Are there new drainalge chaunels'? & & $\because$ & \\
\hline l. Change in surrounding vegetation? & & $\because$ & \\
\hline 2. Security lence, signs. & & & \\
\hline $\begin{array}{l}\text { a. Displacement of fences, sile markers, boundary markers, or } \\
\text { montuments? }\end{array}$ & & $\therefore$ & \\
\hline $\begin{array}{l}\text { b. Have any signs hecn dammed or removed? } \\
\text { (Number of signs replaced: }\end{array}$ & & $\lambda$ & \\
\hline L. Werc galtes locked" & $\lambda$ & & \\
\hline
\end{tabular}


CAU 426: CACTUS SPRING WASTE TRENCHES, POST-CLOSURE INSPECTION CHECKLIST

3. Waste Unit cover.

a. Is there evidesce of seuling?

b. Is there cracking?

c. Is there evidence of crosion around the cap (wind or water)?

d. Is lisere cvidence of auimal burrowing"?

c. [lave the site markers been disturbed by man or natura] processes?

1. Do matural processes threaten to integrity of any cover or site marker"?

y. Other?

4. Vegetative cover.

a. Is perimeter fence or meshl leneing damaged".

b. Is there evidence ol horses or rabbits on sitc"?

c. Is organic muleh and/or pliuts adequate to prevent crosion?

(1. Are weedy annual piauts present?" If yes, are they a problem?

t. Are secded plant species lound on sile?

f. Is there cvidenee of plant mortality?

\begin{tabular}{|c|c|c|}
\hline YES & $\mathrm{NO}$ & EXPLANATION \\
\hline & $\therefore$ & \\
\hline & $x$ & \\
\hline & $\therefore$ & \\
\hline \multirow[t]{4}{*}{$x$} & & Puisnidf TH: GencE \\
\hline & $x$ & \\
\hline & 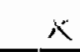 & \\
\hline & $\underline{x}$ & \\
\hline \\
\hline & $\therefore$ & 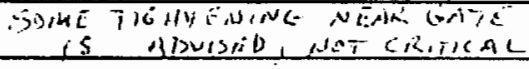 \\
\hline$x$ & & MNuY Horsh PREsinT \\
\hline \multicolumn{3}{|c|}{$x$} \\
\hline & $x$ & \\
\hline \multicolumn{3}{|l|}{$x$} \\
\hline & $\lambda$ & \\
\hline
\end{tabular}

5. Photo Documentation

a Has a photo log heen prepared?

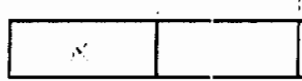

c. Number of photus exposed ( 3 )

\section{FIELD CONCLUSIONS}

1. Is there an inminent bitzard to the integrity of the unit? (munediatc report required)

$x$

Person/Agency to whoni report madc:

2. Are more frequem inspections required?

3. Are existng maintenance/repair actions satisfactory"

4. Is other mintenance/tepatir necessary?

5. Is current status/comdition of vegetative cover satisfactory?

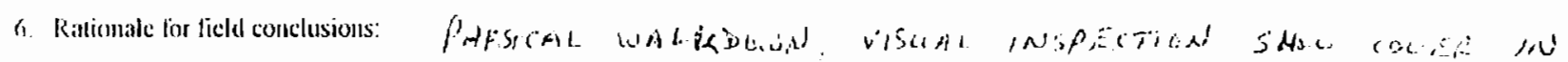

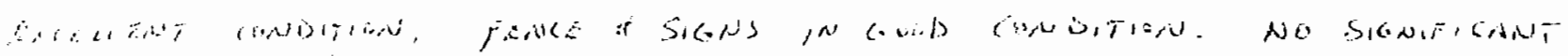

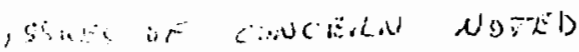

\section{E. CERTIFICATION}

I have conducted an inspection at the Cactus Spring Waste Trenclics. CAU 126 , at the "Tl'R in accordance with the Post-Closure Moniloring Plan (sec Clostre Report) ats recorded on this checklist, attached shects, field notes, photo logs, and photogrilphs.

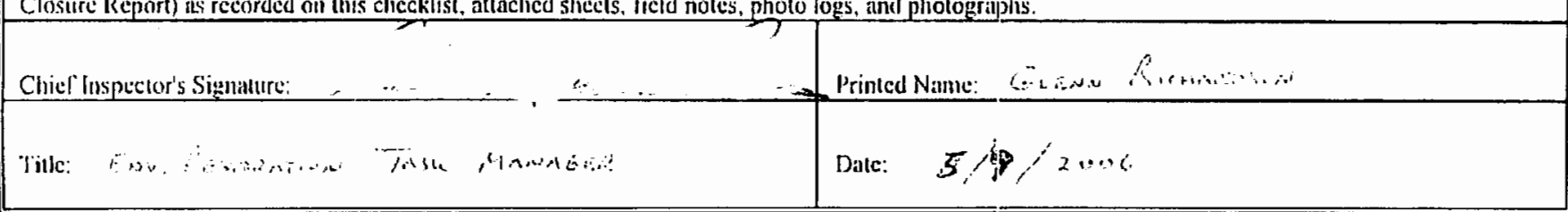




\begin{tabular}{|c|c|c|c|}
\hline \multicolumn{4}{|c|}{ CAU 426: CACTUS SPRING WASTE TRENCHES, POST-CLOSURE INSPECTION CHECKLIST } \\
\hline \multicolumn{4}{|c|}{ Inspection Dute: $\quad 11 / 15 / 06$} \\
\hline Responsible Agency: NNSA/NSO ER & \multicolumn{3}{|c|}{ NNSA Projecr Manager: Pete Sanders } \\
\hline \multirow{2}{*}{\multicolumn{4}{|c|}{\begin{tabular}{l|l} 
Date of Last Inspection: $5 / 9 / 06$ & Reason for Last inspection: Semi- Anneal \\
Inspector (name. litle. organization): Glexn Richardson, Task Manager, NSTec ER
\end{tabular}}} \\
\hline & & & \\
\hline \multicolumn{4}{|c|}{ Assistant inspector (name, title, organization): Reed Poderis, Technical Manager, NSTec ER } \\
\hline \multicolumn{4}{|c|}{ 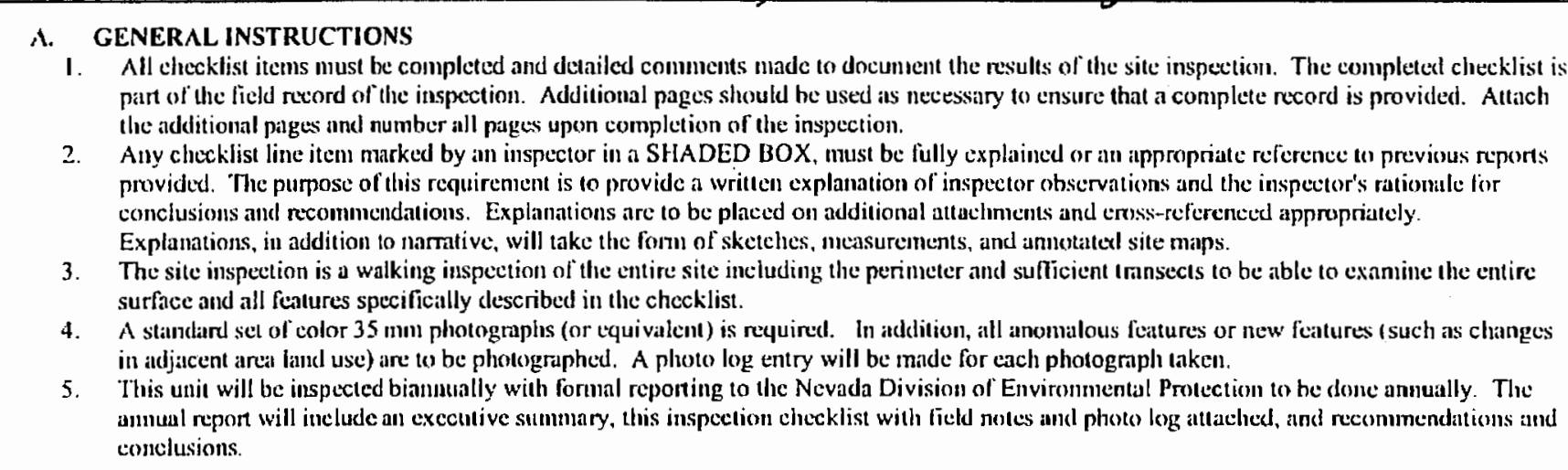 } \\
\hline B. PREPARATION (To be completed prior to sile visit) & YES & NO & EXPLANATION \\
\hline 1. Silc as.built plans and sile base map revieved. & $x$ & & \\
\hline 2. Previous inspection reports reviewed. & $x$ & & \\
\hline a. Were anomalies or trends detected on previous inspections? & & $x$ & \\
\hline b. Was maintenance perlonmed? & $x$ & & $\begin{array}{l}\text { Fence repairs were completed } \\
\text { eis June zoob. }\end{array}$ \\
\hline 3. Silc mainlenance and repair records revicwed. & $x$ & & \\
\hline a. Has site repair resulted in a change fron as-buill conditions:? & & $x$ & \\
\hline b. Are revised as-builts availabic thal retlect repair changes? & & & $N / A$ \\
\hline C. SITE INSPECTION (To be completed during inspection) & YES & NO & EXPLANATION \\
\hline \multicolumn{4}{|l|}{ 1. Adjacent off-site features within waltershed areas. } \\
\hline a. Have there been any chamges in usc of adjacent area"? & & $x$ & \\
\hline b. Are there any new roaids or trails? & & $x$ & \\
\hline c. Has there been a change in the position of nearby washles? & & $x$ & \\
\hline $\begin{array}{l}\text { d. Has there been lateral excursion or crosion/deposition of nearhy } \\
\text { washes? }\end{array}$ & & $x$ & \\
\hline ¿. Are there new drainage clannels? & & $x$ & \\
\hline 1. Change in surrounding vegetation? & & $x$ & \\
\hline \multicolumn{4}{|l|}{ 2. Security fence. signs. } \\
\hline $\begin{array}{l}\text { a. Displacement of lenees, sile markers, boundary markers, or } \\
\text { imonuments? }\end{array}$ & & $x$ & \\
\hline $\begin{array}{l}\text { b. Have any signs been daminged or removed? } \\
\text { (Number of signis replaced: }\end{array}$ & & $x$ & \\
\hline c. Were gates lockcd? & & & $\dot{N} / A$ \\
\hline
\end{tabular}




\section{CAU 426: CACTUS SPRING WASTE TRENCHES, POST-CLOSURE INSPECTION CIECKLIST}

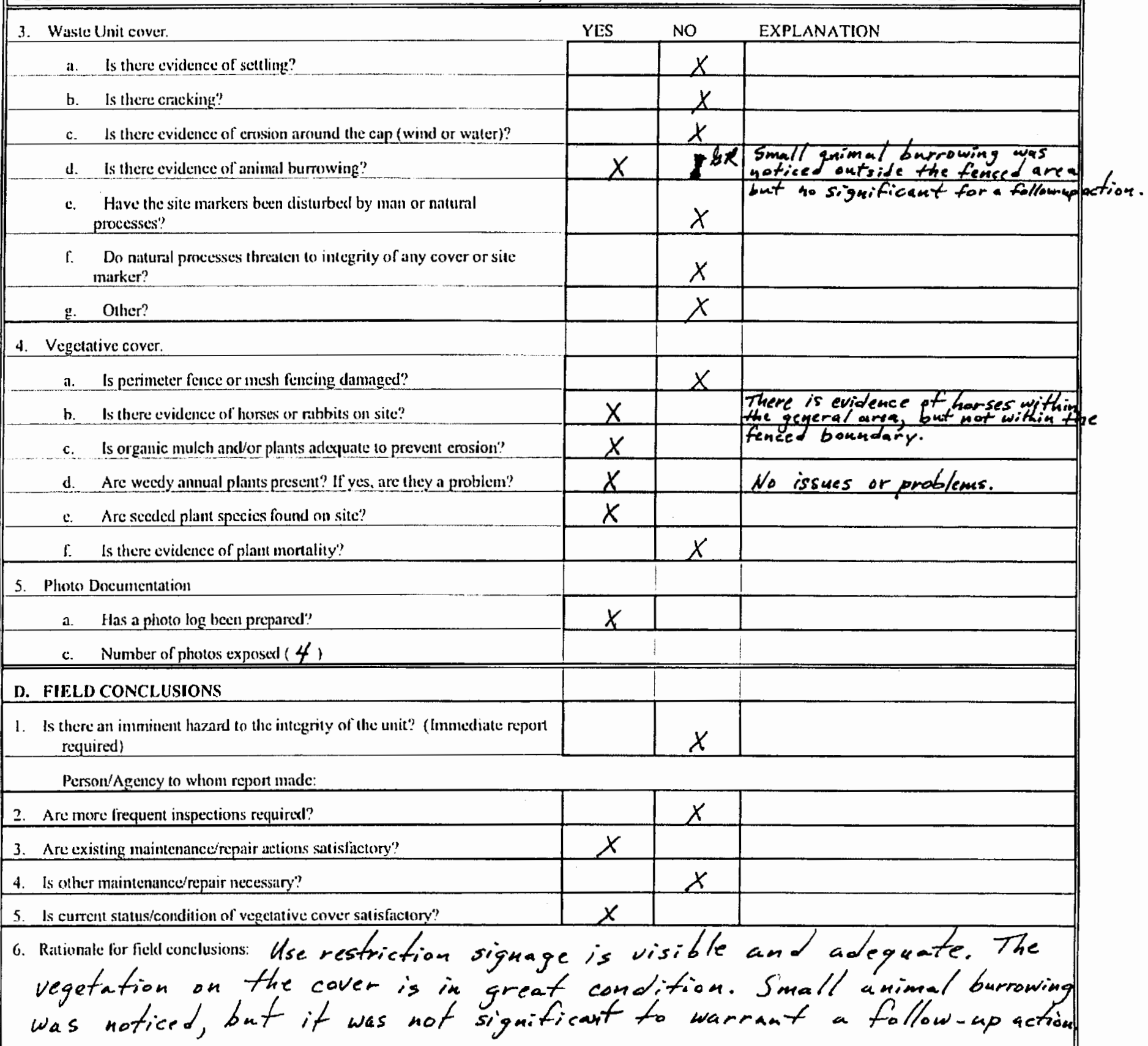

\section{E. CERTIFICATION}

I have conducted an inspection of the Cactus Spring Waste Trenches, CAU 426, at the 'TrR in accordance with the Post-Closure Monitoring Plan (see Closure Report) as recorded on (lis cliecklist, attaclied sheets. field motes, photo ings, and photographs.

\begin{tabular}{|l|l|l||}
\hline Chief Inspector's Signature: & Printed Nanc: G/enn Kichardson \\
\hline Tille: Task Manager & Dale: \\
\hline
\end{tabular}




\begin{tabular}{|c|c|c|c|}
\hline \multicolumn{4}{|c|}{ CAU 427: AREA 3 SEPTIC WASTE SYSTEMS $2 \&$ 6, POST-CLOSURE INSPECTION CHECKLIST } \\
\hline \multicolumn{4}{|l|}{ Inspection Dalk: $₹$; / $/ 20<2$} \\
\hline Responsible Agency: NNSNNSO ER & \multicolumn{3}{|c|}{ NNSA Project Miulager: KëU,N CNdízZE } \\
\hline Datc of Last Inspection: $\quad \because j ;, ;, \cdots+\cdots$ & \multicolumn{3}{|c|}{ 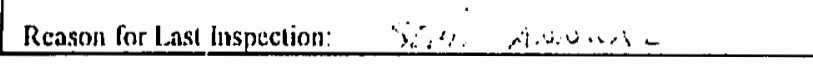 } \\
\hline 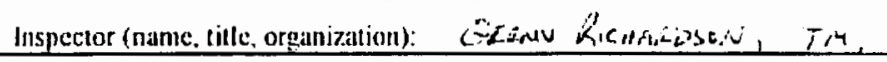 & \multicolumn{3}{|c|}{$B N E A$} \\
\hline \multicolumn{4}{|c|}{ 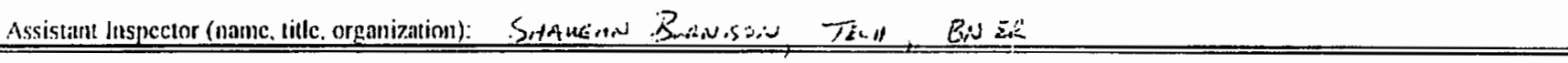 } \\
\hline \multicolumn{4}{|c|}{ 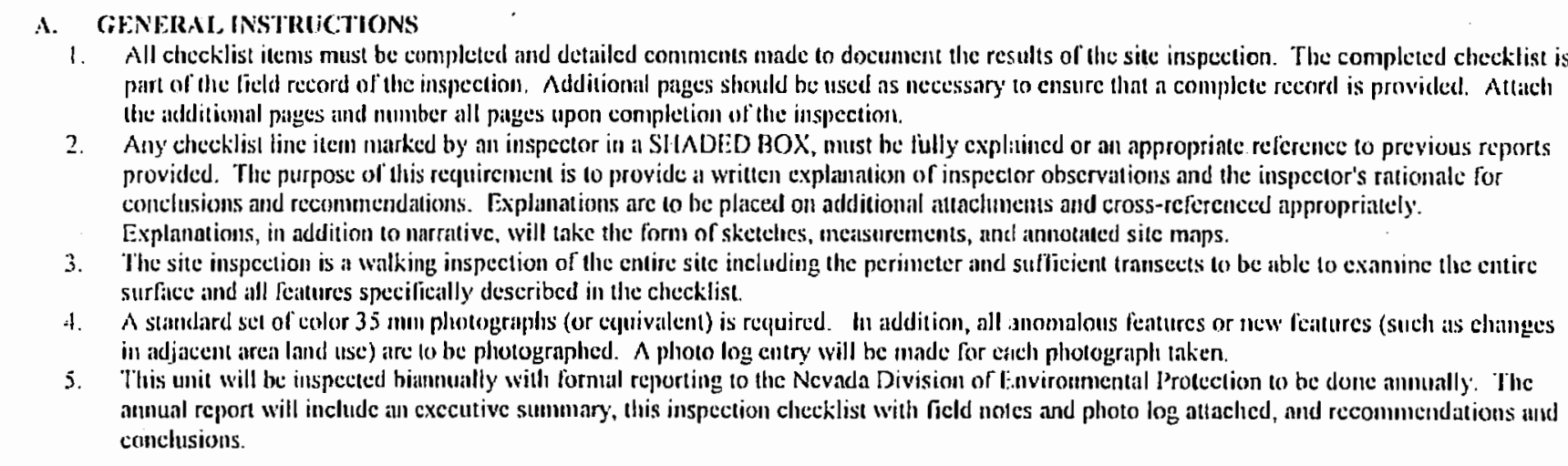 } \\
\hline B. PREPARATION (To be completed prior to site visit) & YES & INO & EXPLANATION \\
\hline 1. Silc as-built plans and silc basc map revicwed. & ie & & \\
\hline \multirow{3}{*}{$\begin{array}{l}\text { 2. Previous inspection reports reviewed. } \\
\text { a. Were anomialies or trends delected on previous inspections"? } \\
\text { b. Was mainlenance performed"? }\end{array}$} & $x$ & & \\
\hline & & $\underline{x}$ & \\
\hline & $x$ & & \\
\hline \multirow{3}{*}{$\begin{array}{l}\text { 3. Site maintenance and repair records reviewed. } \\
\text { a. Has site repair resulted in a chauge from as-built conditions? } \\
\text { b. Are reviscd as-builts available that reflect repair changes? }\end{array}$} & $\ddot{x}$ & & \\
\hline & & 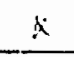 & \\
\hline & & & \\
\hline C. SITE INSPECTION (To be completed during inspection) & YES & LO & EXPLANATION \\
\hline \multicolumn{4}{|l|}{ 1. Adjacent off-site features with in wattershed areas. } \\
\hline at Hlive there been any changes in use of adjacenl area? & & $\therefore$ & \\
\hline b. Are there any new ronds or trilits? & & $\underline{x}$ & \\
\hline \multicolumn{4}{|l|}{ 2. Security signs. } \\
\hline $\begin{array}{l}\text { a. Displacencmt of sile markers, boundary markers, or monuments? } \\
\text { (disturbed by man or uitural processes?) }\end{array}$ & & $\ddot{x}$ & \\
\hline $\begin{array}{l}\text { b. Have uny sigus been dimaged or removed? } \\
\text { (Number of signs replazed: }\end{array}$ & & $x$ & \\
\hline $\begin{array}{l}\text { C. Were all subsurfince narkers detceted"? (i.c., using a magnatonicter } \\
\text { or equivalent) }\end{array}$ & $\therefore$ & & \\
\hline
\end{tabular}


CAU 427: AREA 3 SEPTIC WASTE SYSTEMS $2 \& 6$, POS'T-CLOSURE INSPECTION CHECKLIST

3. Soil/aspluarlı cover.

a. Is there evidence of setling":

b. Is there craching"?

c. Is there evidence of erosion near use restriclion boundarics?

d. Is there evidcuce of animal burrowing'?

c. Is there vegetation?

f. Do matural processes threaten to integrity of any cover or site marker?

g. Is there cvidence suggesting unituthorized cxcavations have taken place"?

c. Other?

\begin{tabular}{|l|r|l|}
\hline \multicolumn{1}{|c|}{ YES } & \multicolumn{1}{l}{ NO } & \multicolumn{1}{l}{ EXPLANAIION } \\
\hline & $x$ & \\
\hline & $x$ & \\
\hline & $x$ & \\
\hline & $x$ & \\
\hline & $x$ & \\
\hline & $x$ & \\
\hline & $x$ & \\
\hline & & Na \\
\hline & & \\
\hline
\end{tabular}

\section{FIFID CONCLIISIONS}

1. Is there an inminemt hazatrd to llue inegrily ol the unit? (Immediate repont required)

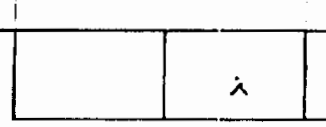

l'ersen/Agency to whom report madd

2. Are more frequent inspections required"?

3. Are existing maintenance/repair actions satisfactory?

.1. Is other maintenance/repair necessiry?

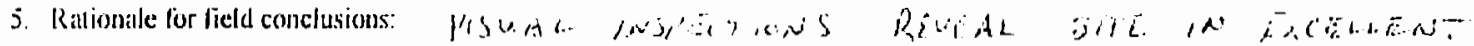

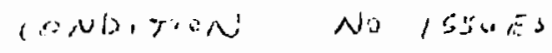

\section{E. CEIRTIFICATION}

[ lave conducted an inspection of the Arcia 3 Septic Waste Systcous 2 \& 6, CAU 427, at the TTrR in accordance with the Post-Closure Monitoring Pliu (sec Closure Report) as recorded on this checklist, attached sheets. ficld notes, photo logs. and pliotographs.

Cluch luspector's Signiature

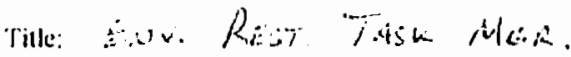

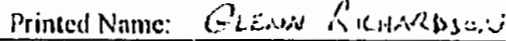

Date: $\quad 5 / 4 / 2006$ 


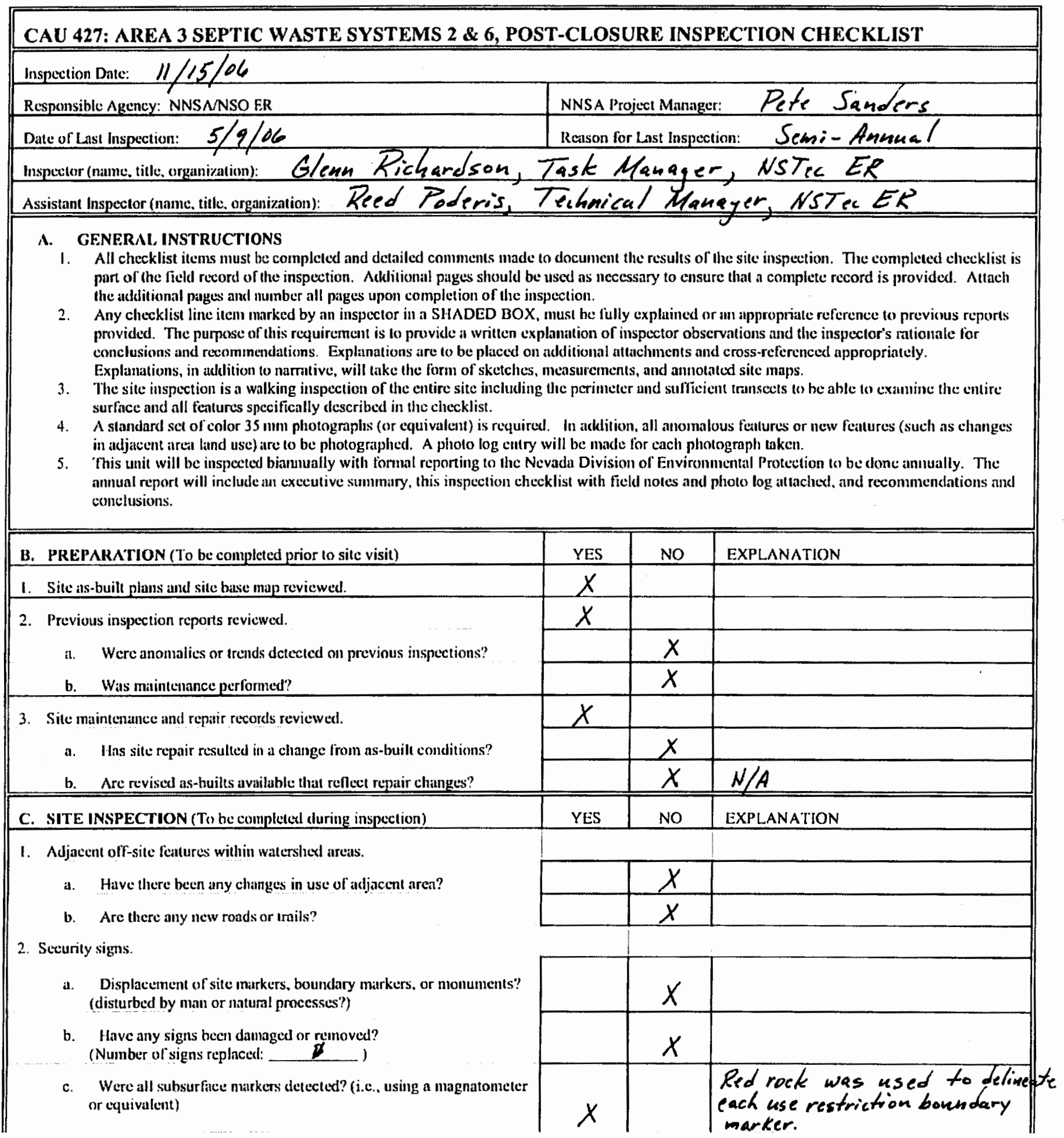




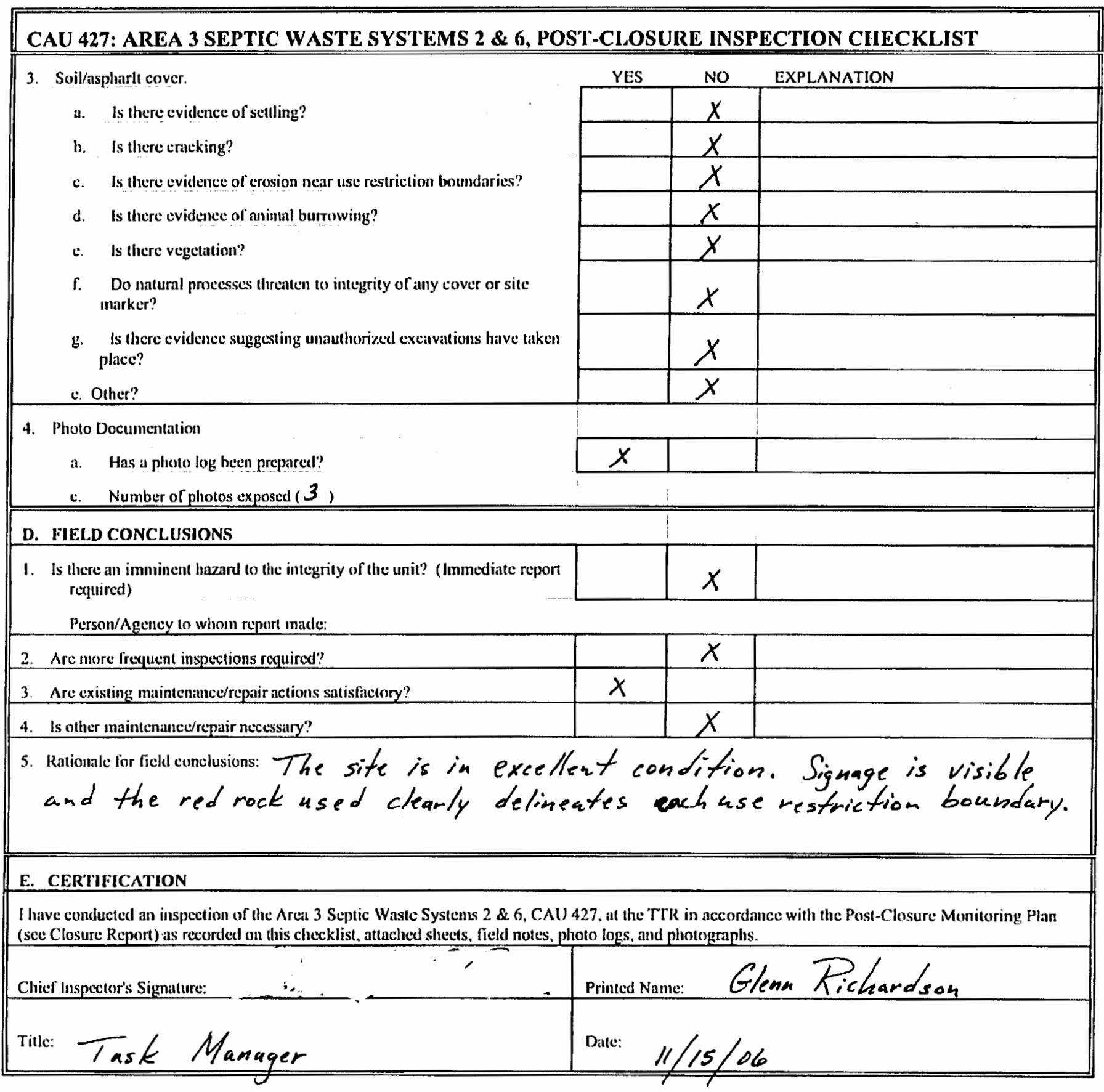


CAU 453: ARCA 9 UXO LANDFILL, POST-CLOSURE INSPECTION CHECKLIST

Inspection Diale: $5 / 31 / 06$

Responsible Agency: NNSA/NSO IRR

Datc of last Inspection: $1 / / 15 / 05$

lispector (name. litlc, organization): Glener Richardson

Assistanu Insprecor (name tillc, organization): Reed Poderis

A. GENLIRAL INSTRUCTIONS

I All checklist items must be completed and detailed comments made to document the results of the site inspection. The conpleted checklist is part of the field record of the inspection. Adelitional pages shoutd be used as neessary to ensure that a complete record is provided. Altich the additional pages mod unmber all pages upou completion of the inspection.

2. Any checklist line item marked by an inspector in a SIIADED BOX, must be fully explained or an appropriate reference to previous reports provided. The purpose of this requirement is to provide a writlen explantation of inspector observalions and the inspector's rationale for conclusions :und recommendations. Explanations are to be plated ou additional atlachoments and cross-referenced appropriately.

Explanations, in addition to narrative, will take the linm of sketches, measurements, and annutated site maps.

3. The site inspection is a walking inspection of the entire site including the perimeter and suffieient transects to be able to examine the centire surfiace and ill leatures specifically described in the checklist.

4. A standard set of color $35 \mathrm{~mm}$ photograplss (or equivulent) is required. In addition, all momalous fealures or new fentures (stuch as chamges in idtjacetut arca land use) are to be pholograplied, $\wedge$ photo log entry will be mide for each photograph taken.

5. This unit will be inspected biannually with formal reporting to the Nevada Division of Einvironmental Protection to be done antunally. Tile

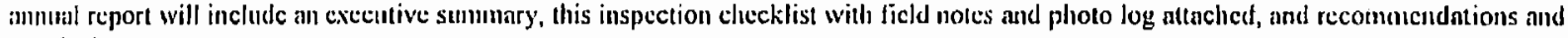
conclusions.

\begin{tabular}{|l} 
B. PRERARATION (To he completed priar to site visit) \\
1. Site as-built plans ind site bilse map reviewed. \\
2. Previous imspeclion reports reviewed. \\
a. Werc anomalies or trends detected on previous inspections? \\
b. Was maintemance performed?
\end{tabular}

3. Sile maistenturce and repnir records reviewed.

a. Hils sitc repair resulted in a change from as-built conditions?

b. Are revised as-builts available that reflect repair chianges?

C. SITE INSPECTION (To be completed during inspection)

1. Adjacent off-site fientures within watershed areas

a. Have therc been any changes in use of adjacent axes?

b. Are there any new roads or trails?

c. Ilas there been a change in the position of neirby washes?

d. Has tlere heen lateral excursion or crosion/deposition of nearby' washes?

c. Are there ncw drainage channels?

f. Clange in surrounding vegetition?

\begin{tabular}{|c|c|c|}
\hline YES & vo & EXPLANATION \\
\hline$L^{\prime}$ & & \\
\hline$\nu$ & & \\
\hline$\checkmark$ & & $\begin{array}{l}\text { subsidences were repaired in the } \\
\text { previous inspections. }\end{array}$ \\
\hline$\checkmark$ & & \\
\hline$\swarrow$ & & \\
\hline & $\checkmark$ & \\
\hline & & $N / A$ \\
\hline YES & NO & EXPIANATION \\
\hline & & 1 \\
\hline & $V$ & \\
\hline & レ゙ & \\
\hline & 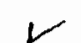 & \\
\hline & $v^{\prime}$ & \\
\hline & $v^{\prime}$ & \\
\hline & $v$ & \\
\hline
\end{tabular}

2. Securily fonce. signs.

a. Displacement of lences, site markers, boundary markers, or moumments?

h. I have imy signs been damaged or, removed? (Number of signs replaced: )

c. Were gates locked?

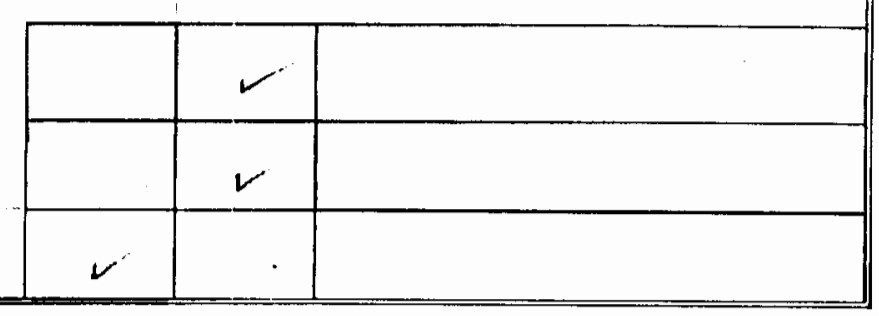




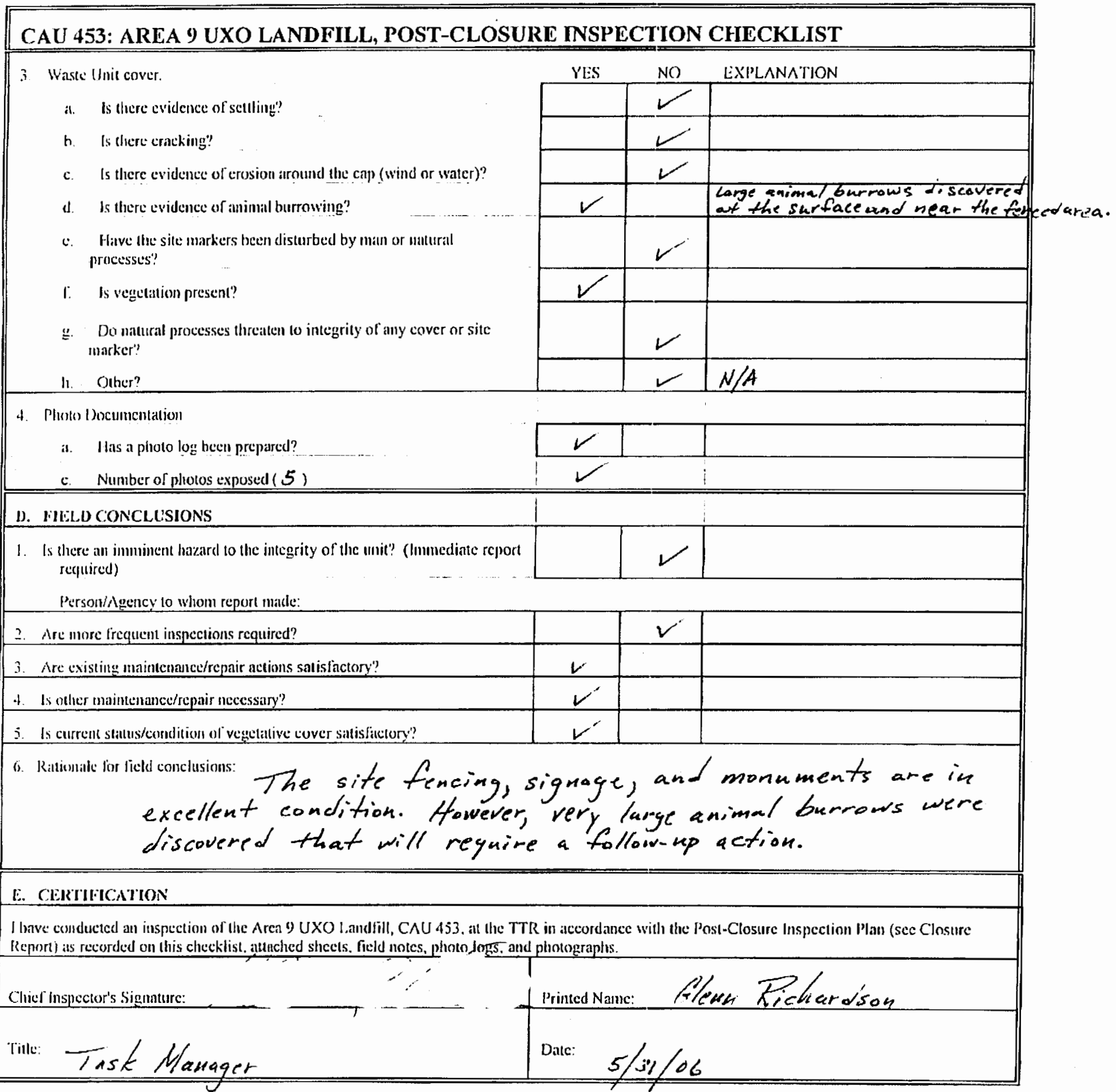




\section{CAU 453: AREA 9 UXO LANDFILL, POST-CLOSURE INSPECTION CHECKLIST}

\begin{tabular}{|c|c|}
\hline Inspection Date: $\quad 11 / 15 / 06$ & \\
\hline Responsible Agency: NNSANSO ER & NNSA Project Manager: Pete Sanders \\
\hline Date of Last Inspection: $\quad 5 / 31 / 06$ & Reason for Last lnspectim: Sem; - Anmual \\
\hline Inspector (name, litle, organization): & Task Maneger NSTec ER \\
\hline
\end{tabular}

A. GLNERAL. INSTRUCTIONS

1. All checklist items must be completed and detailed comments made to document the results of the site inspection. The completed checklist is part of the field record of the inspection. Additional pages should be used as neeessary to ensure that a complete record is provided. Altach the additional pages and number all pages upon completion of the inspection.

2. Any elecklist line item mirked by an inspector in a SHADED BOX, must be lully explained or an appropriate reference to previnus reports provided. The pupose ol this requirement is to provide a written explanation of inspector observations and the inspector's rationale lor conclusions and reconunendations. Explanitions are to be placed on additional attueluments und cross-relerenced appropriately. Explanations, in addition to narrative, will take the form of sketelies, measurements, ind annotated site maps.

3. The site inspection is a walking inspection of the entire site including the perineter and suflicient transects to be able to examine the entire surfine and all features specifically described in the checklist.

4. A standard set of color $35 \mathrm{~mm}$ phologmpls (or equivalent) is required. In addition, all anomalous features or new features (such as changes in adjacent area land use) are to be plotographed. A photo log eniry will be made lor each plotograph taken.

5. This unit will be inspected biamually with formal reponting to the Nevada Division of Environmental Protection to be done annually. The annual report will include an executive summary, this inspection checklist with fiekd noles and pholo log attaclicd, and reconmendations and conclusions.

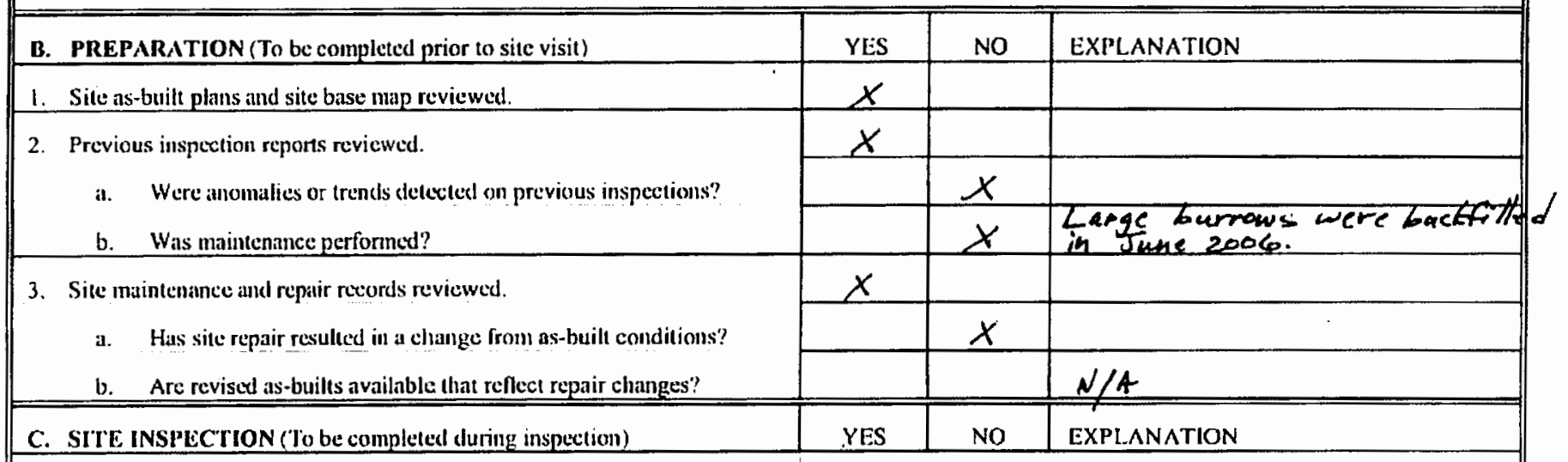

1. Adjacent off-site features within watershed arcas.

ก. Have there been any clianges in use of adjacent area?

b. Are there any new roads or trails?

c. Has there been a change in the position of nearby washes?

d. Has there been lateral excursion or erosion/deposition of nentby washux?

e. Are there new drainage chamnels?

i. Clıange inı surrounding vegetalion?

2. Sceurity fence, signs.

i. Displacenent of fences, sile inarkers, boundary markers, or monuments?

b. Have any signs been danaged or removed? (Number of signs replaced: $\left.q^{\prime}\right)$

c. Were gilles lexked?

\begin{tabular}{|l|l|l|}
\hline & $x$ & \\
\hline & $x$ & \\
\hline & $x$ & \\
\hline & $x$ & \\
\hline & $x$ & \\
\hline & $x$ & \\
\hline & $x$ & \\
\hline & $x$ & \\
\hline$x$ & & \\
\hline
\end{tabular}




\section{CAU 453: AREA 9 UXO LANDFLL, POST-CLOSURE INSPECTION CHECKLIST}

3. Waste Unit cover.
a. Is there tvidence of seilling?
b. Is there cracking'?
c. Is there evidence of crosion around the eap (wind or water)?
d. Is there evidence of animail burnowing?
c. Have the site mirkers been disturbed by man or natural processes?
i. Is vegetation present?
g. Do maturai processes threaten to inlegrily of any cover or site imarker?
I. Other?

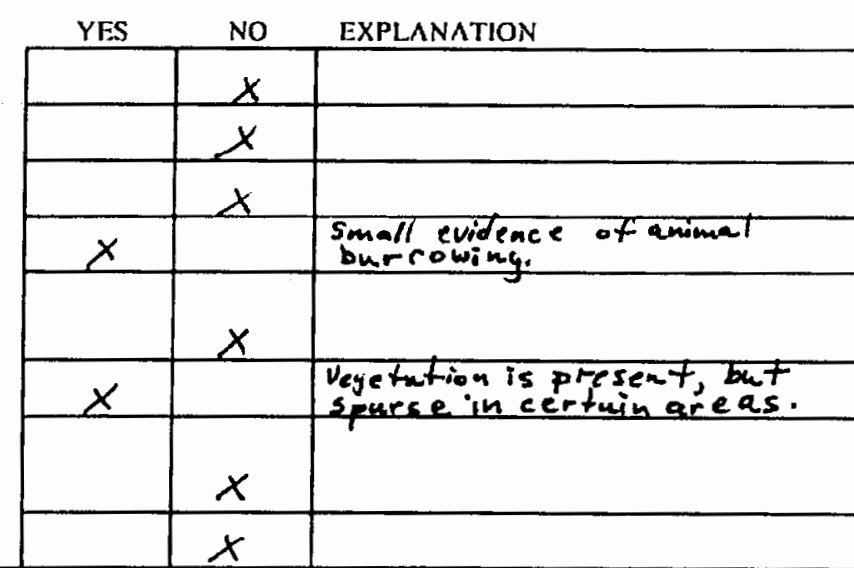

4. Pinoto Documentation
a. Has a photo log been prepared?
c. Number of photos exposed (3)

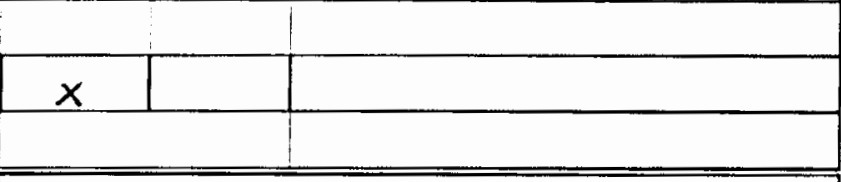

\section{FIELD CONCLUSIONS}

1. Is there an imminent hazard to the integrity of the unit? (Imnediate report required)

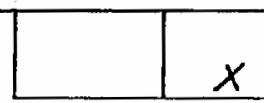

Person/Agency to whom report inikle:

2. Are more frequent inspections required"?

3. Are cxisting maintenanco/repair actions satisfactory".

4. Is other maintenancetrepair necessary?

5. Is current status/condition of vegctative cover satisfactory?

6. Rationale for ficld conclusions: The ebovegraund monnments are in good conelition. Small animal burrowing was noticed, but significant enough to warrant a follow-mp action.

\section{E. CERTIFICATION}

I have conducted an inspection of the Area 9 UXO Landlill, CAU 453, at the TTR in accordance will the Post-Closure Inspection Plan (sec Closure Report) as recorded on this checklist, attached sheets, liefl notes, photo logs, and photographs.

Chice luspectnr's Signature:

$\because \quad$\begin{tabular}{l|l|} 
Printed Name: Gleme Aichardson \\
Dinte: $11 / 15 / 06$
\end{tabular}




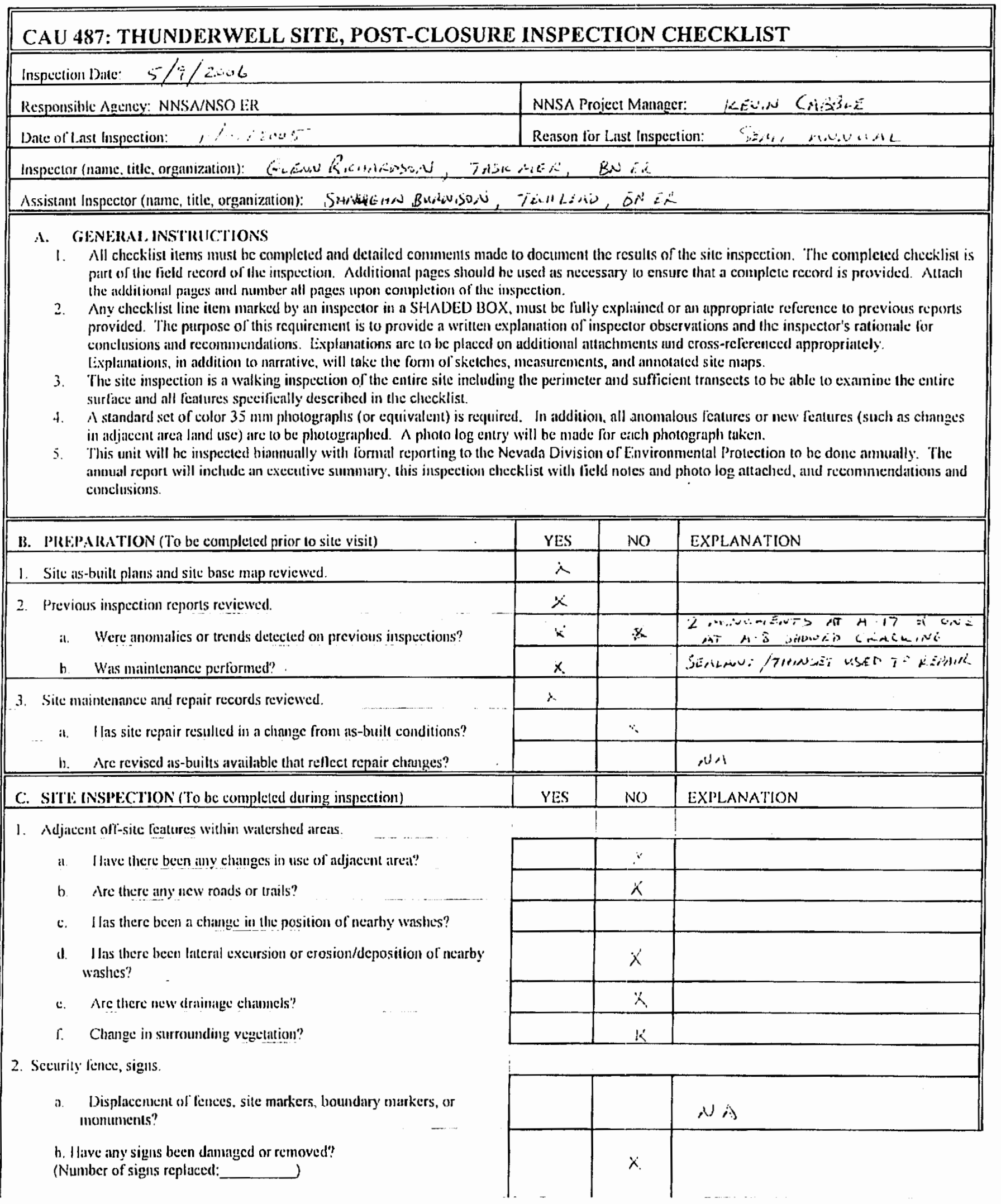




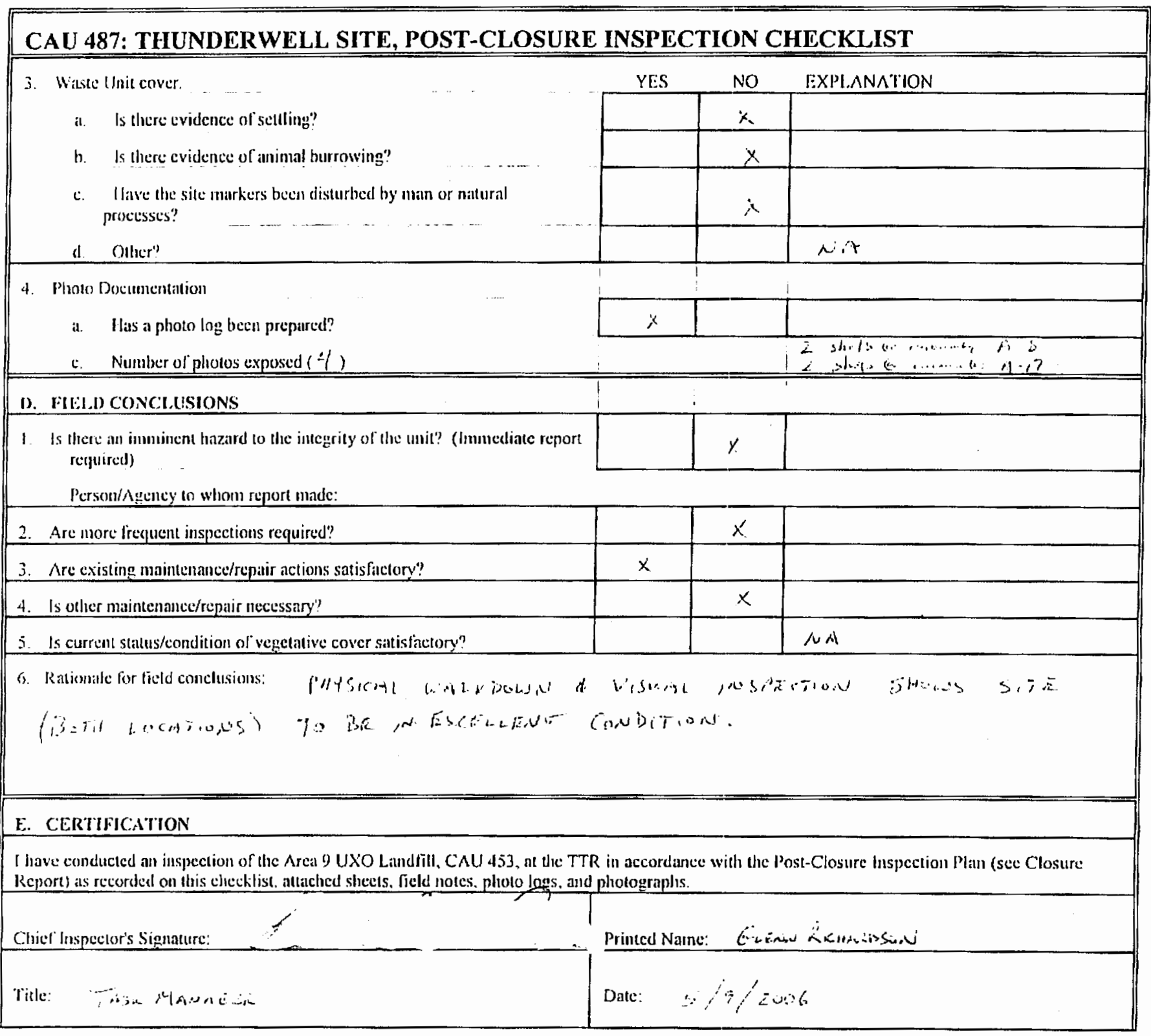




\begin{tabular}{|c|c|c|c|}
\hline \multicolumn{4}{|c|}{ CAU 487: THUNDERWELL SITE, POST-CLOSURE INSPECTION CHECKLIST } \\
\hline \multicolumn{4}{|l|}{ Inspection Date: $\quad 11 / 15 / 06$} \\
\hline Responsible Agency: NNSA/NSO ER & \multicolumn{3}{|c|}{ NNSA Project Manager: Pete Sanders } \\
\hline \multirow{2}{*}{\multicolumn{4}{|c|}{ 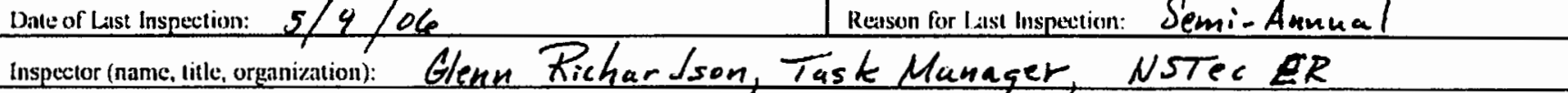 }} \\
\hline & & & \\
\hline \multicolumn{4}{|c|}{ Assistant Inspector (name, title, organizntion): Reed Poderis Technical Mamager NSTec ER } \\
\hline \multicolumn{4}{|c|}{ 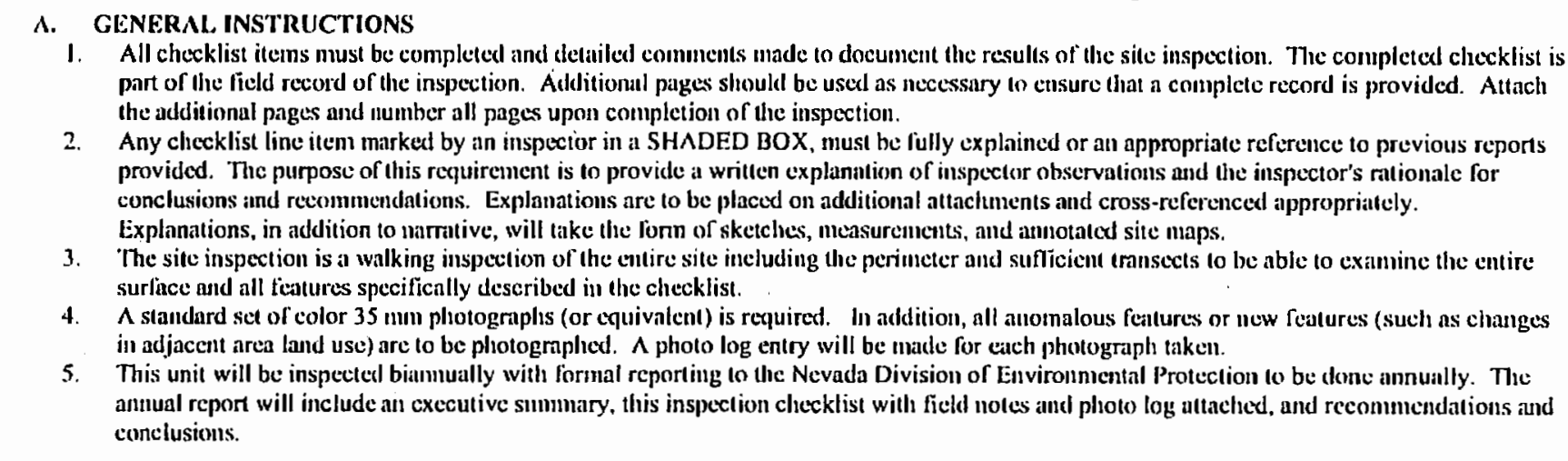 } \\
\hline B. PREPARATION (To be completed prior to site visit) & YES & No & EXPLANATION \\
\hline 1. Sile as-built plans and site base map reviewed. & $\underline{x}$ & & \\
\hline 2. Previous inspection reports revicwed. & $x$ & & \\
\hline it. Were anomalies or Irends detected on previous inspections? & & $x$ & \\
\hline b. Was mainlenanec perfonned? & & $x$ & \\
\hline & $x$ & & \\
\hline \multirow{2}{*}{$\begin{array}{l}\text { 3. Sile milintenance and repair records reviewed. } \\
\text { a. Hass sile repair resulted in a change from as-built conditions? }\end{array}$} & & $X$ & \\
\hline & & & $N / A$ \\
\hline C. SITE INSPECTION (To be compieted during inspection) & YES & NO & EXPLANATION \\
\hline \multicolumn{4}{|l|}{ 1. Adjacent off-site fealures wilhin walcrshed areas. } \\
\hline \multirow{2}{*}{$\begin{array}{l}\text { a. Have there been any clanges in use of adjacent area? } \\
\text { b. Are there any new ronds or trails? }\end{array}$} & & $x$ & \\
\hline & & $x$ & \\
\hline $\begin{array}{l}\text { b. Are there any new roads or trails? } \\
\text { c. llas there been a change in the position of neturby washes? }\end{array}$ & & $x$ & \\
\hline $\begin{array}{l}\text { d. Has there been lateral excursion or crosion/dcposition of nearby } \\
\text { watshes? }\end{array}$ & & $x$ & \\
\hline \multirow{2}{*}{$\begin{array}{l}\text { e. Are there new drainage channels? } \\
\text { f. Change in surrounding vegetation? }\end{array}$} & & $x$ & \\
\hline & & $x$ & \\
\hline \multicolumn{4}{|l|}{ 2. Security fence, signs. } \\
\hline $\begin{array}{l}\text { i. Displacement of fences, site markers, boundary markers, or } \\
\text { monuments? }\end{array}$ & & $x$ & \\
\hline $\begin{array}{l}\text { b. Have any signs been damaged or removed"? } \\
\text { (Number of signs replaced: }\end{array}$ & & & \\
\hline
\end{tabular}




\begin{tabular}{|c|c|c|c|}
\hline \multicolumn{4}{|c|}{ CAU 487: THUNDERWELL SITE, POST'CLOSURE INSPECTION CHECKLIST } \\
\hline \multirow{5}{*}{$\begin{array}{l}\text { 3. Waste Unit cover. } \\
\text { a. Is there evidence of settling? } \\
\text { b. Is there evidence of animal burrowing? } \\
\text { c. Have the site markers been disturbed by man or natural } \\
\text { processes? } \\
\text { d. Other? }\end{array}$} & \multirow{2}{*}{\begin{tabular}{|l|l}
\multicolumn{1}{|c|}{ YES } \\
\end{tabular}} & \multirow{2}{*}{ No } & \multirow{2}{*}{ EXPL.ANATION } \\
\hline & & & \\
\hline & & $x$ & \\
\hline & & $\underline{x}$ & \\
\hline & & $x$ & \\
\hline \multicolumn{4}{|l|}{ 4. Photo Documentation } \\
\hline a. Has a photo log been prepared? & $x$ & & \\
\hline c. Nuniber of photos exposed ( 3 ) & & & \\
\hline \multicolumn{4}{|l|}{ D. FIELD CONCLUSIONS } \\
\hline \multirow{2}{*}{\multicolumn{4}{|c|}{$\begin{array}{l}\text { 1. Is there an inmminent havarsl to the integrity of the unit? (Immediitte report } \\
\text { required) } \\
\text { Person/Agency to whom report made: }\end{array}$}} \\
\hline & & & \\
\hline \multicolumn{4}{|l|}{ 2. Are inore frequent inspections requirexl? } \\
\hline \multicolumn{4}{|l|}{ 3. Are existing maintenance/repair actions satisfactory? } \\
\hline \multicolumn{4}{|l|}{ 4. Is other maimlenancedrepair necessary? } \\
\hline 5. Is current status/condition of vegetative cover satisfictory? & & $2 x$ & $N / A$ \\
\hline \multicolumn{4}{|c|}{$\begin{array}{l}\text { 6. Rarionile for ficld conclusions: The aboveground monuments are erect and in good } \\
\text { condition. The signage is in good condition. }\end{array}$} \\
\hline \multicolumn{4}{|c|}{ E. CERTHFICATION } \\
\hline \multicolumn{4}{|c|}{ 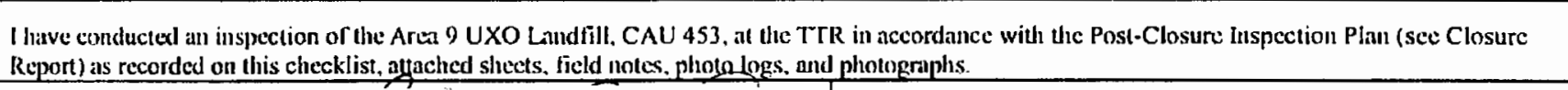 } \\
\hline Chice Inspector's Signature: . . & \multicolumn{3}{|c|}{ Primed Niane: Glenn Richardson } \\
\hline Title: Task Manuger & \multicolumn{3}{|c|}{ Date: $\quad 11 / 15 / 08$} \\
\hline
\end{tabular}


Post-Closure Inspection Report - TTR

Revision: 0

Date: June 2007

Attachment D.

FIELD NOTES

D-1 
Post-Closure Inspection Report - TTR

Revision: 0

Date: June 2007

\section{THIS PAGE INTENTIONALLY LEFT BLANK}

D-2 
136 TITLE TTR POST-CLOSURE INSPECTIONS Work continued from Page NA May 9 , 2006
PROJECT NO. TIR PCM BOOK NO. 1

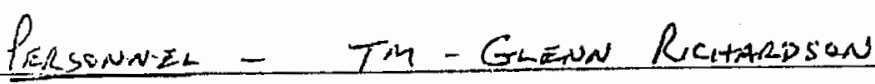

Th. Shaugran Burnison

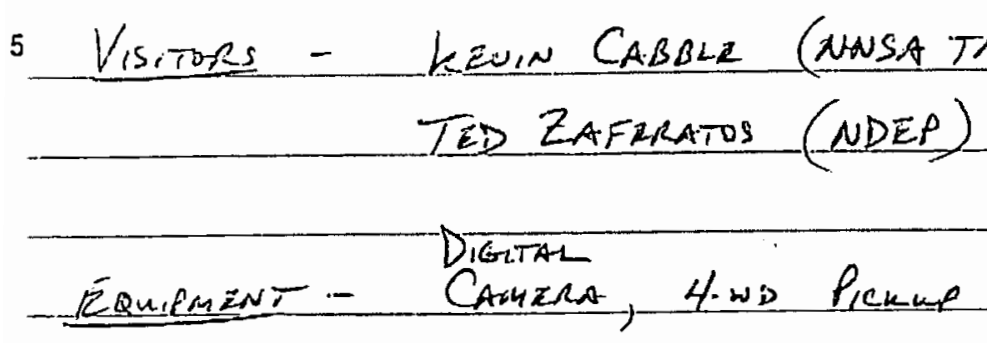

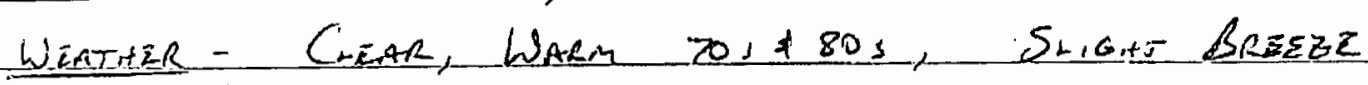

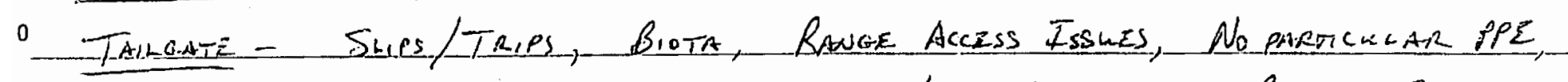

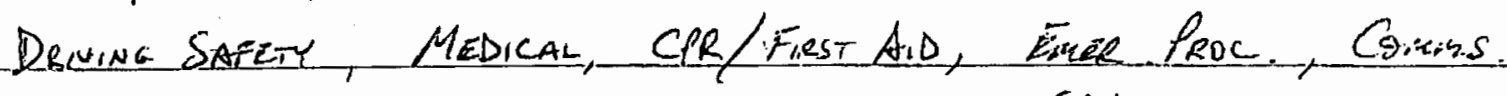

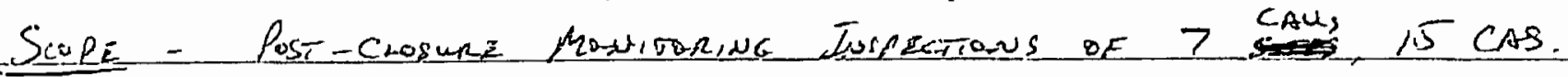

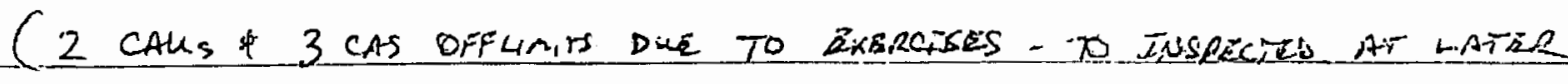
DATE)

5

ACTUGTIES - 2:00-09:30 PICKUP PHOTO PASS FRO.4 BLDG 100, RETREUE CAMERA FAOML GNTE

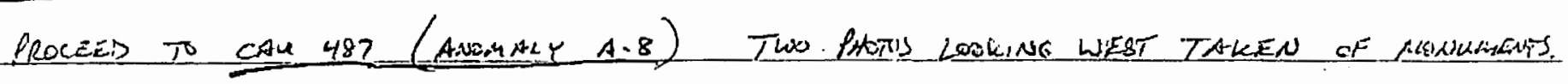

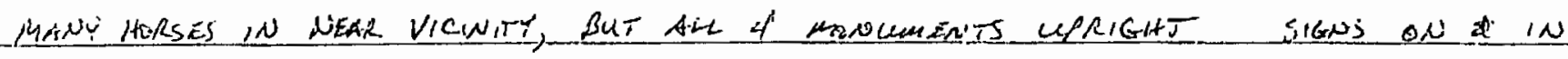

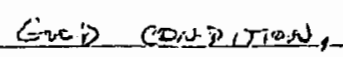

0

10.10

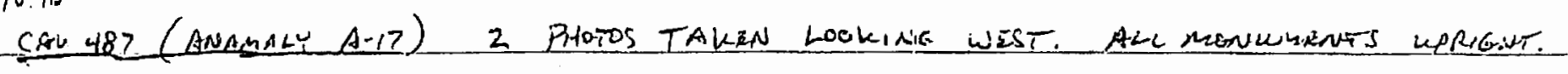

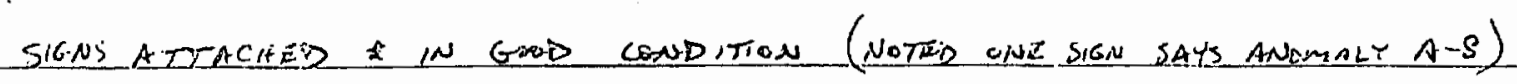

$10: 30-10: 40$

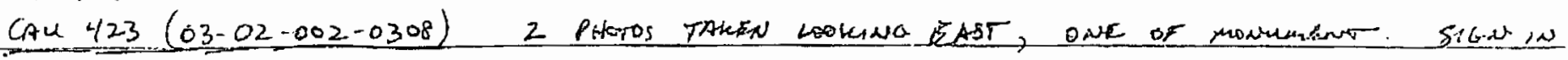
GoOD CONDition, 


\section{TITLE}

Work continued from Page 137
PROJECT NO.

BOOK NO.

\section{ACTUTTES CONTHUED - 13:00-15:00}

\section{CAu 427}

\section{CLTENTS}

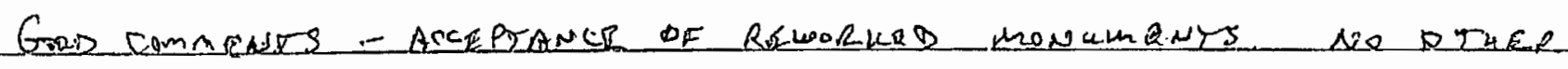

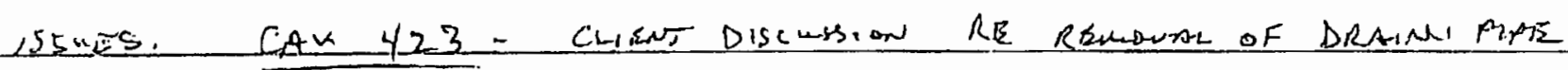
AssocintidD w/ THLS CAS. RISh of UTIL LINE BRRACLT.

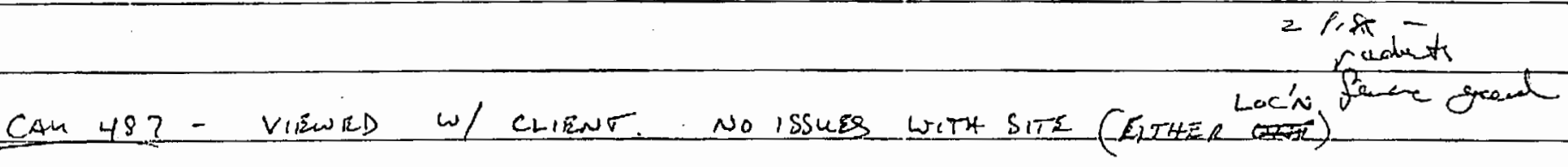

ㄱ) $26,530-1545$

15:00-17:30 CAK 424 - FENEE \& SIGNS OKAY. SOME ANIMAL BURRONS NEJED,

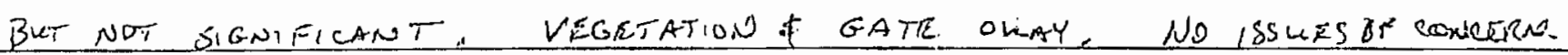

CAL407 - FENCE IN GOOD CONDITION EXCEPT SE CORNER POSTS NEED RENFORCING E STRANDS IIGHTENED RAD POSTINGS ARE FADED BADLY.

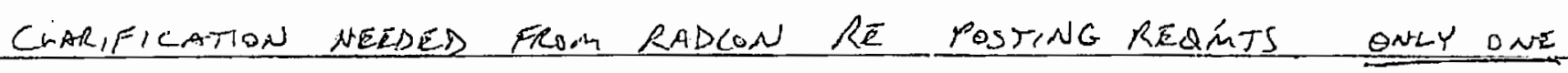
CONTROLED AREA SIGN IS pOSTED AT THE ENTMANGE THRRE IS A QUESTION WIETTRR TITERE SHOULD BE (OR COULA BE) SLGNB POSTJD ON TAE THREF OTHER SIDES AS THAS IS A WRMN WITH SIGNIFICANT BURIED

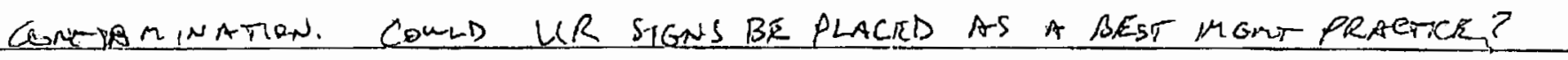

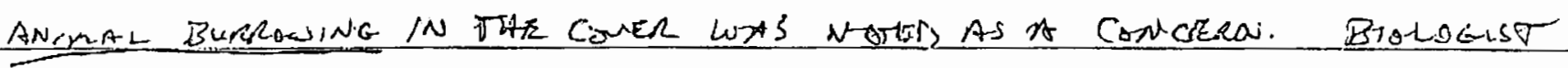

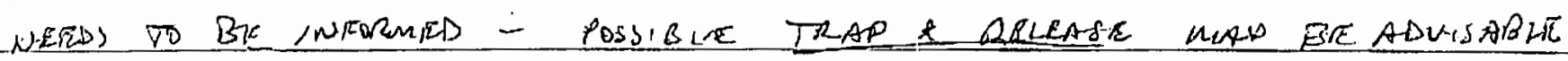

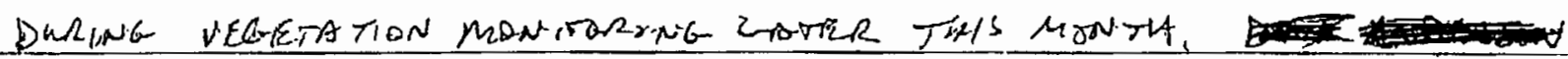

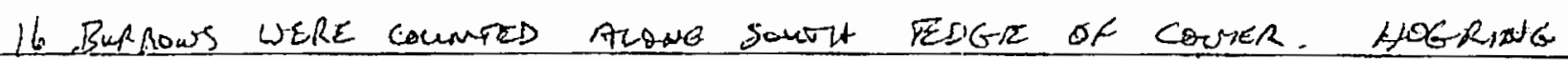

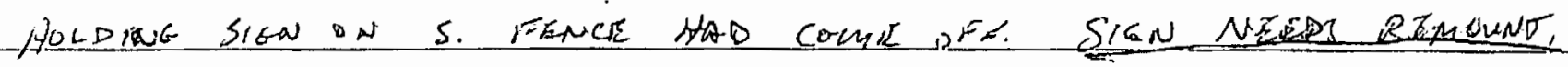

CAU 426 - CACTUS SPRINGS: ARRMED \& PARKED AT THE GATE. A STEEHBLE HEPD DF HORSES WIRE GATHERED NAAR THE SPRNG. OTHER WDWIDUAS WERE IN THE GENERAL ARIAA. GATE WAS LORKED. NO RENTRANCE WAS MLADE. IJALKED

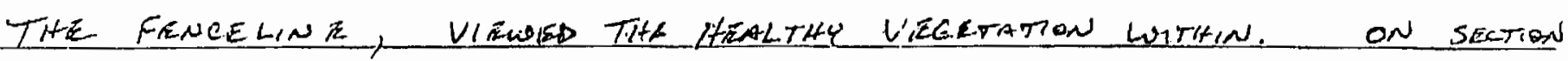
CIENTIFIC DINDERY PRODUGTIONS GMICAGO GOGOS Mada In USA Work continued to Page 139 


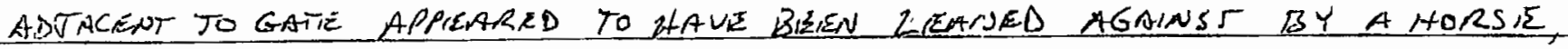
BQUING IT NWARD. FENCE REMANBD JATACT BUT PULLING THA WIRE

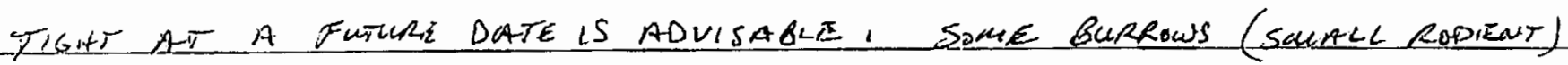

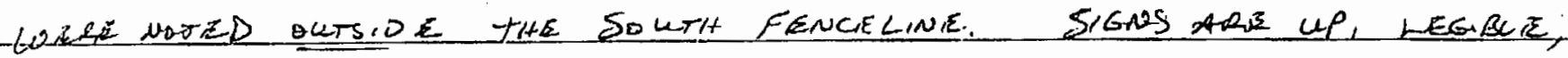

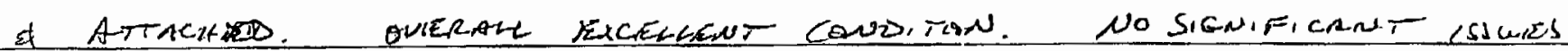
QFe Conconen.

CAM 404-ROZLRR COASTER LAGDONS: NO ENTRY MADE, FIEUGELINE WALLED. GATE, EENCE, SIGNAGE DE VEGETATON IN EXCELLENT CONDTTON. CHENT NOTED THAT IT MAY BR TIME TO RORMALLY PROPOSE REMUWAL ON THE FENCE AS VEGETATION WITHA AREA ZE IN COUER MATCHES

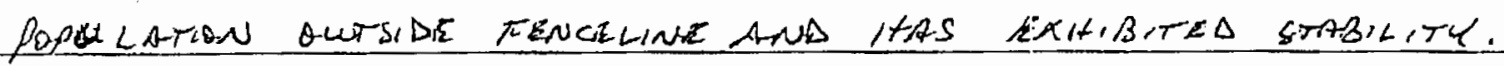

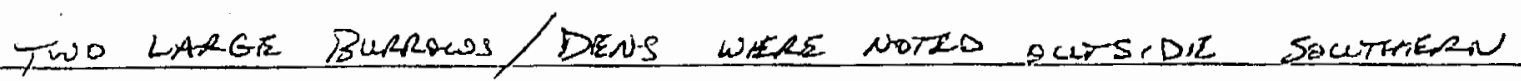

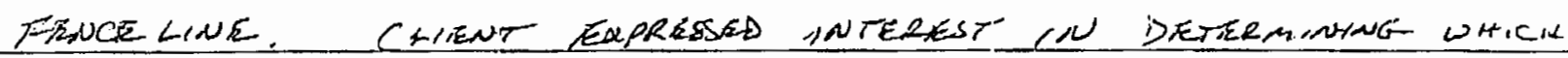

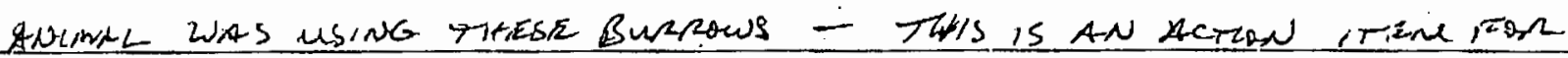

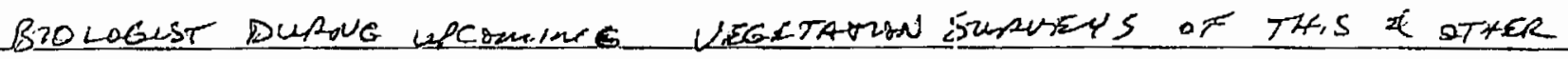

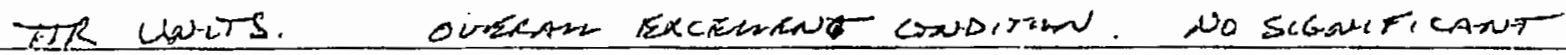

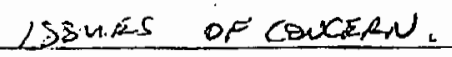
CAU HOQ - BOMBLET PIT SE PTS LANDEILL No INSPECTIONS of THESTE CAM 453 - AREAT Q WNO LANDFIL SITES DU Tits DorTE

THE ABOUK TWO STES WLR OFF LOUTS DUE TD AN ZKERCISE ON THE

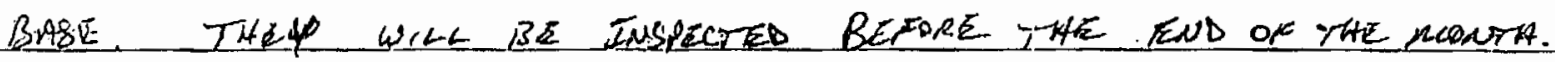
WTIY THIS EXCEPTLON - 
$\$ 40$ TITLE

Work continued from Page
PROJECT NO.

BOOK NO.

May 31, 200e TTR Post Closure Inspections for CAL 453 and CAUL 400

Purpose: Inspections could not be performed on May 9 with other TTR sites because areas for $C A 4453$ and CAM 400 were restricted due to classified site exercises.

Personal: Glenn Richardson

Reed Poderis

Equipment: Digital Camera

Weather: Warm, 90's

Tailgate: Be aware of biological hazards (snakes, scorpions, bees, etc.) slips/Trips/Ealls Medical/ CPR First Aid Heat stress conditions Communications - TTR Radio Security is on ASI net.

PPE: Standard Level D (Safety Shoes, Glasses, and Hard hat (if Hecessarin))

Scope: Perform semiannual inspections for Cru 453: uso Landfill, CAn 400: Bomblet Pit Site, and CAl $400 \leq$ Pts. Landfill site.

Arrived at TTR gate at approx. 10:30 4M. Picked up camera permit at approx. 11:05 AM.

CAk453- Arrived at Area 9 uxo Landfill site at 11:15 AM. Performed tailgate safety briefing and began site inspection at $11: 22 \mathrm{AM}$.

Used combination code on p lock to access gate. Performed walton of the internal fenced area. We noticed large animal burrows on the northeast corner of the 49-1 Trench and along the northern fence perimeter. We also noticed miscell aeneous scrap on the ground surface. A walkdown was also performed around the external fenced area. The aboveground monuments are in good condition and vegeturiom growth appears normal. Inspection phat ss were taken of the site and animal burrows.

Work continued to Page SIGNATURE

DATE.

$5 / 31 / 06$ 
PROJECT NO.

141

Work continued from Page

BOOK NO.

Left CAU453 Area 9 usO Landfill at 12:020M. Adjourned to Lunch. Lunch Hows mend at 12:30 PM

- CAll 400 - 5 Points Land fill

Arrived at site at 1:20 PM. Performed walk. down around fence perimeter. Inspection photos (i) were taken of the site area. Fencing appeared to be in good condition. Small animal burrows were noticed inside and outside of the fence withinthertheast corner. No significuntissues were noticed at the site. Vegetation appeared normal, but will be inspected by plant specialist an Tare Left the 5 Paints Landfill at 1:45 PM.

- CAM 460 - Bomblet Pit Site

Arrived at site at 2:50 PM. Performed walk down around fence perimeter. Inspection photos (') were taken of the site area. T-posts and barb wire fencing are in good condition, however; the chicken wire fencing on the west and

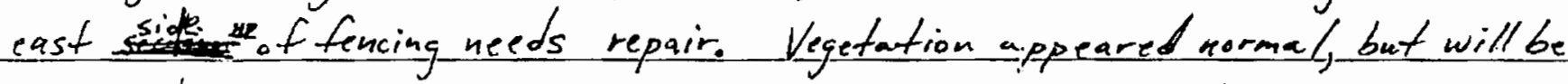
inspected by plant specialist on June 13-14, 2006. Fond d booklet with suspect do fuse. Left the Eomblet Pit site at

Westinghouse (Jerry) will be contacted.

- Bombe was markid-with-orange classing between departing the site.

- CAUs for TTR Inspections are complete. Heading buck to BN Office traitor and subsequently heading back to Mercury.

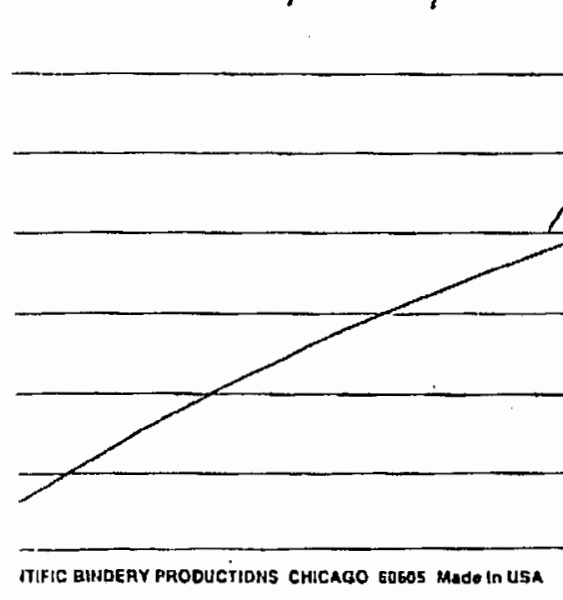

TIFIC RINDEAY PRODUCTIDNS CHICAGO gOGOL Made In USA

inATURE

Work continued to Page

Thar 
TITLE

Work continued from Page
PROJECT NO. TTR Past Closure BOOK NO. 3

TTR Post Close Monitoring Inspection (SemsidAnnwal)

Personnel: Kevin Coble - NNSA, Pete Sanders - NNSA

Glean Richardson- NSTec ER Task Manager

5

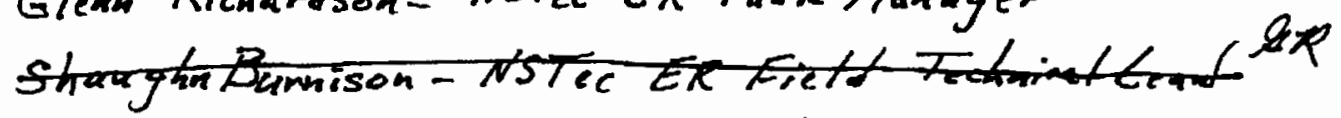

Reed Poderis - NSTec ER Technical Manager

Equipment: Camera

Weather: Sunny, Cool, Breezy

Scope: Perform Semi-Annual TTR Post Closure Inspections Tailgate Safety Briefing: Cold Stress, Slips, Trips, Falls,

Range Access Issues, Medical, First Aid

8:05 AM - Arrived at CAM 487. Performed site inspection of monuments 15 and took photo documentation. There were no issues at the A-8 or A-17 sites. All monuments are erect and signage is in good condition. Departed from CAU 687 at $6: 254 M$.

8:44 AM- Arrived at CAM 453. Performed site inspection with photo documentation. The aboveground monuments are in good condition. There was some small anisonul burrowing noticed, but it was not viewed as significant enough to warrant a follow-up action. Departed from CAM 453 at 9:05 AM. 9:16 AM - Arrived at CAU 400- 5 Pts. Landfill. Performed site inspection and noticed that the vegetation was all dead i due to flooding in the area. NSTec took an action to discuss this issue the NSTec plant is eco-services ing to get a recommendation if replanting is necessary, monitoring for new vegetation in the spring, or evaluating other alternatives.

www.scientilicbindery88yrs.com SIGNATURE

DISCLOSED TO AND UNDERSTOOD BY.
Work continued to Page 2 DATE

DATE

WITNESS
$11 / 15 / 06$ 
2

TITLE

Work continued from Page
PROJECT NO.

BOOK NO.

The site conditions were confirmed with photo documentation. After photos were taken, we left 5 ph. at 9:30.

9:39 AM - Arrived at CAUl 400 Bomblet Pit.

There are no site issues at the Billet Pit. Previous fence repair was maintained and signage is in good condition. Photos were taken and departed the site at 9:50 AM.

10:03 AM - Arrived at CAU 404. Performed the site inspection with photo documentation. Observed the vegetative cover to find it in goad condition. The fencing and signage was without damage- No animal burrows were on the site. Departed soy at 10:15 HM.

10:18 AM -Arrived at CAU 407. Inspected the site to find the fencing, cover, and signage in a good condition. There were no animal burrows at this site. Photo documentation was completed and left the site at 10:25 AM.

10:40 AM - Arrived at CAU 426. Inspected the Cactus s Springs site and fraud no issues. The signage ord fencing are in good condition. Photos were taken. Also, noticed - some small burrowing outside of the fenced site boundary. Departed the site at 10:52 AM, in route bact to Area 3 Man-Camp for Lunch.

::30m Returned to ER Trailer after lunch.

wow scientificbinderybByrs.com SIGNATURE

DISCLOSED TO AND UNDERSTOOD BY
Work continued to Page 3

DATE

DATE

$11 / 15 / 06$ 


\section{TITLE}

Work continued from Page
PROJECT NO.

BOOK NO.

13:15PM - Arrived at CAM 427. Inspected each site use-resfriction boundary marker, to make sure the red rock cover was visible enough to delimeate the site. The signage is in good condition. There was photo documentation taken, 5 but no issues were at this site.

13:30PM - Arrived at $\mathrm{CM}_{423} 3$. The inspection was pertamed at the use-restriction area and photo documentation was takter.

Signage is in good condition. Lett c4ll 423 heading to the sites at CAU 424 .

13:35 PM-Arrived at CAU 424. Performed inspection of all sites. The aboveground and at-grade monuments are not damaged and in good condifion. Photo documentation wat taken. No issues. Departed the last CAM 424 site at 14:15 PM. NNSA headed back to Narth LN.

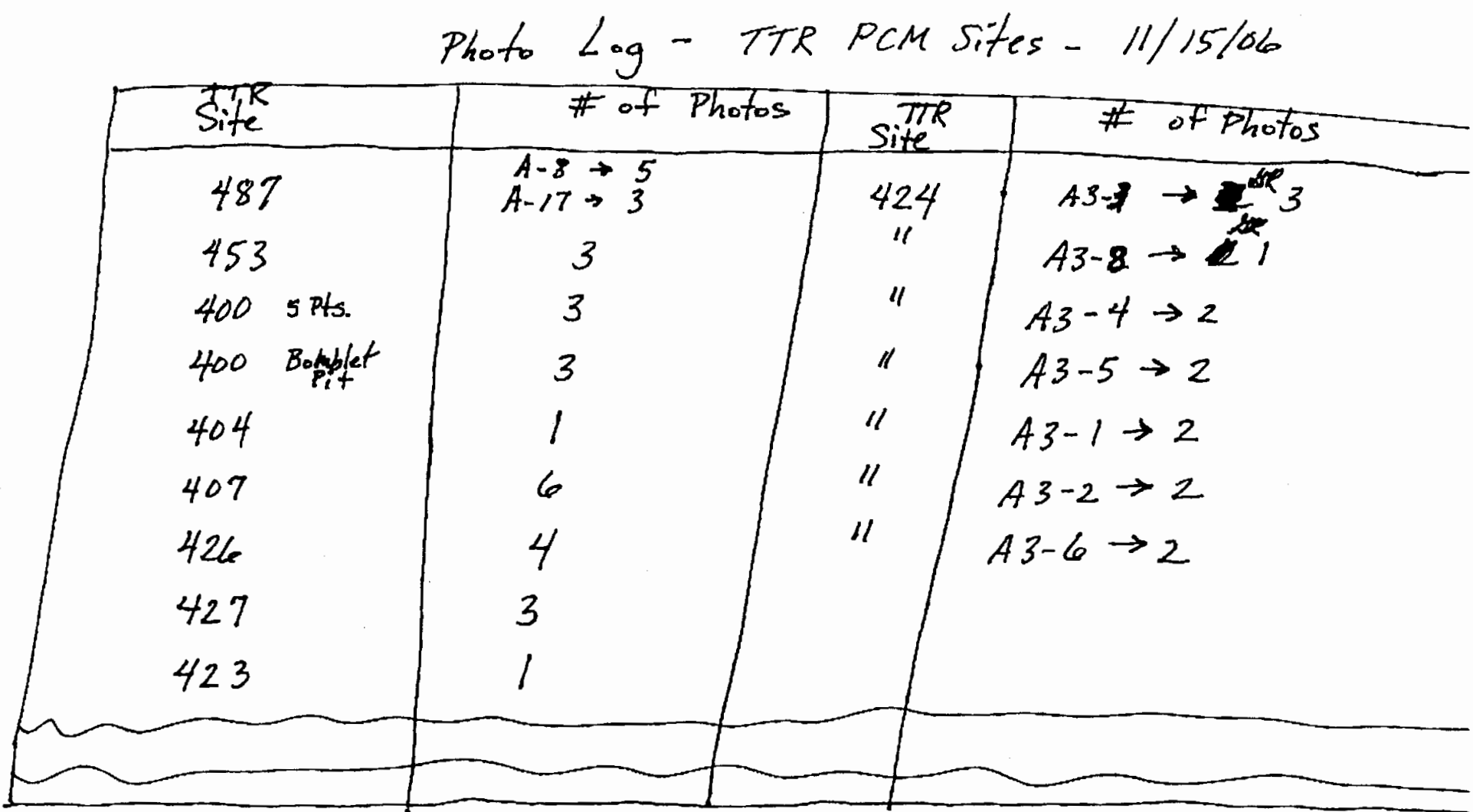

www.scientificbindery88yrs.com

SIGNATURE

DISCLOSED TO AND UNDERSTOOD BY
Work continued to Page

DATE DATE 
Post-Closure Inspection Report - TTR

Revision: 0

Date: June 2007

\section{THIS PAGE INTENTIONALLY LEFT BLANK}


Post-Closure Inspection Report - TTR

Revision: 0

Date: June 2007

\section{ATtACHMENT E PhotographS}


Post-Closure Inspection Report - TTR

Revision: 0

Date: June 2007

\section{THIS PAGE INTENTIONALLY LEFT BLANK}




\section{PHOTOGRAPH LOG}

\begin{tabular}{|c|c|c|}
\hline PHOTOGRAPH & DATE & DESCRIPTION \\
\hline 1 & $05 / 31 / 2006$ & CAU 400 Bomblet Pit, looking west \\
\hline 2 & $11 / 15 / 2006$ & CAU 400 Bomblet Pit, looking south \\
\hline 3 & $05 / 31 / 2006$ & CAU 400 Bomblet Pit, looking north \\
\hline 4 & $11 / 15 / 2006$ & CAU 400 Bomblet Pit, looking north \\
\hline 5 & $05 / 31 / 2006$ & CAU 400 Five Points Landfill, looking east \\
\hline 6 & $11 / 15 / 2006$ & CAU 400 Five Points Landfill, looking east \\
\hline 7 & 05/31/2006 & CAU 400 Five Points Landfill, looking west \\
\hline 8 & $11 / 15 / 2006$ & CAU 400 Five Points Landfill, looking west \\
\hline 9 & 05/09/2006 & CAU 404, looking east \\
\hline 10 & $11 / 15 / 2006$ & CAU 404, looking east \\
\hline 11 & 05/09/2006 & CAU 407, looking east \\
\hline 12 & $11 / 15 / 2006$ & CAU 407, looking east \\
\hline 13 & 05/09/2006 & CAU 407, looking southwest \\
\hline 14 & $11 / 15 / 2006$ & CAU 407, looking northeast \\
\hline 15 & 05/09/2006 & CAU 423, looking east \\
\hline 16 & $11 / 15 / 2006$ & CAU 423, looking east \\
\hline 17 & 05/09/2006 & CAU 424, Landfill Cell A3-1, looking south \\
\hline 18 & $11 / 15 / 2006$ & CAU 424, Landfill Cell A3-1, looking north \\
\hline 19 & 05/09/2006 & CAU 424, Landfill Cell A3-2, looking north \\
\hline 20 & $11 / 15 / 2006$ & CAU 424, Landfill Cell A3-2, looking north \\
\hline 21 & 05/09/2006 & CAU 424, Landfill Cell A3-3, looking east \\
\hline 22 & $11 / 15 / 2006$ & CAU 424, Landfill Cell A3-3, looking west \\
\hline 23 & 05/09/2006 & CAU 424, Landfill Cell A3-3, looking north \\
\hline 24 & $11 / 15 / 2006$ & CAU 424, Landfill Cell A3-3, looking north \\
\hline 25 & 05/09/2006 & CAU 424, Landfill Cell A3-4, looking northeast \\
\hline 26 & $11 / 15 / 2006$ & CAU 424, Landfill Cell A3-4, looking north \\
\hline 27 & 05/09/2006 & CAU 424, Landfill Cell A3-5, looking southeast \\
\hline 28 & $11 / 15 / 2006$ & CAU 424, Landfill Cell A3-5, looking southeast \\
\hline 29 & 05/09/2006 & CAU 424, Landfill Cell A3-6, looking northwest \\
\hline 30 & $11 / 15 / 2006$ & CAU 424, Landfill Cell A3-6, looking northwest \\
\hline 31 & 05/09/2006 & CAU 424, Landfill Cell A3-8, looking west \\
\hline 32 & $11 / 15 / 2006$ & CAU 424, Landfill Cell A3-8, looking west \\
\hline
\end{tabular}


Date: June 2007

\begin{tabular}{|c|c|l||}
\hline PHOTOGRAPH & DATE & \multicolumn{1}{|c||}{ DESCRIPTION } \\
\hline \hline 33 & $05 / 09 / 2006$ & CAU 426, looking north \\
\hline 34 & $11 / 15 / 2006$ & CAU 426, looking north \\
\hline 35 & $06 / 02 / 2006$ & CAU 427, looking north \\
\hline 36 & $11 / 15 / 2006$ & CAU 427, looking northwest \\
\hline 37 & $05 / 09 / 2006$ & CAU 427, looking south \\
\hline 38 & $11 / 15 / 2006$ & CAU 427, looking south \\
\hline 39 & $05 / 31 / 2006$ & CAU 453, looking west \\
\hline 40 & $11 / 15 / 2006$ & CAU 453, looking west \\
\hline 41 & $05 / 09 / 2006$ & CAU 487, A-8 anomaly, looking west \\
\hline 42 & $11 / 15 / 2006$ & CAU 487, A-8 anomaly, looking southwest \\
\hline 43 & $05 / 09 / 2006$ & CAU 487, A-17 anomaly, looking west \\
\hline 44 & $11 / 15 / 2006$ & CAU 487, A-17 anomaly, looking southwest \\
\hline
\end{tabular}




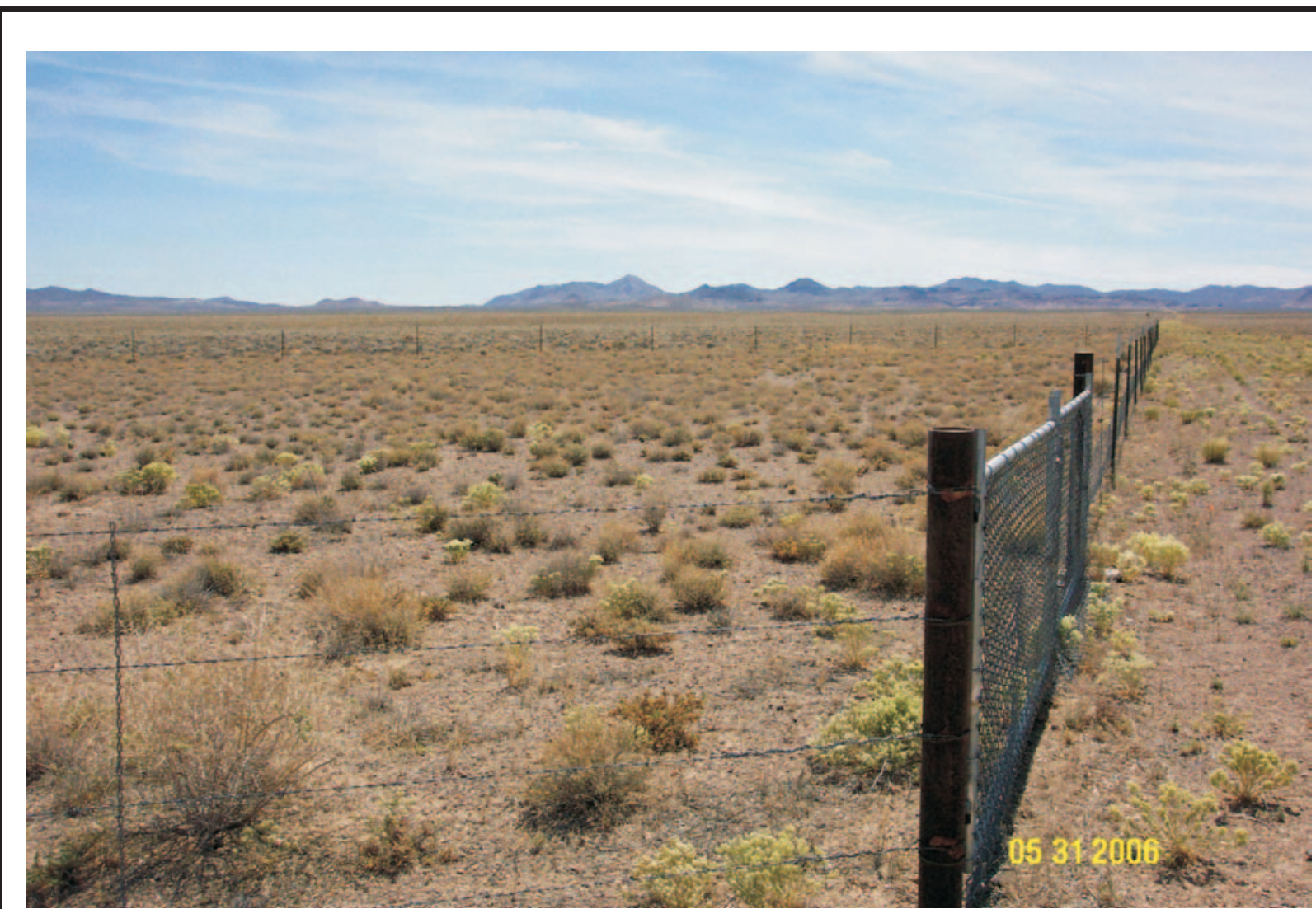

Photograph 1: CAU 400 Bomblet Pit, looking west, 05/31/2006

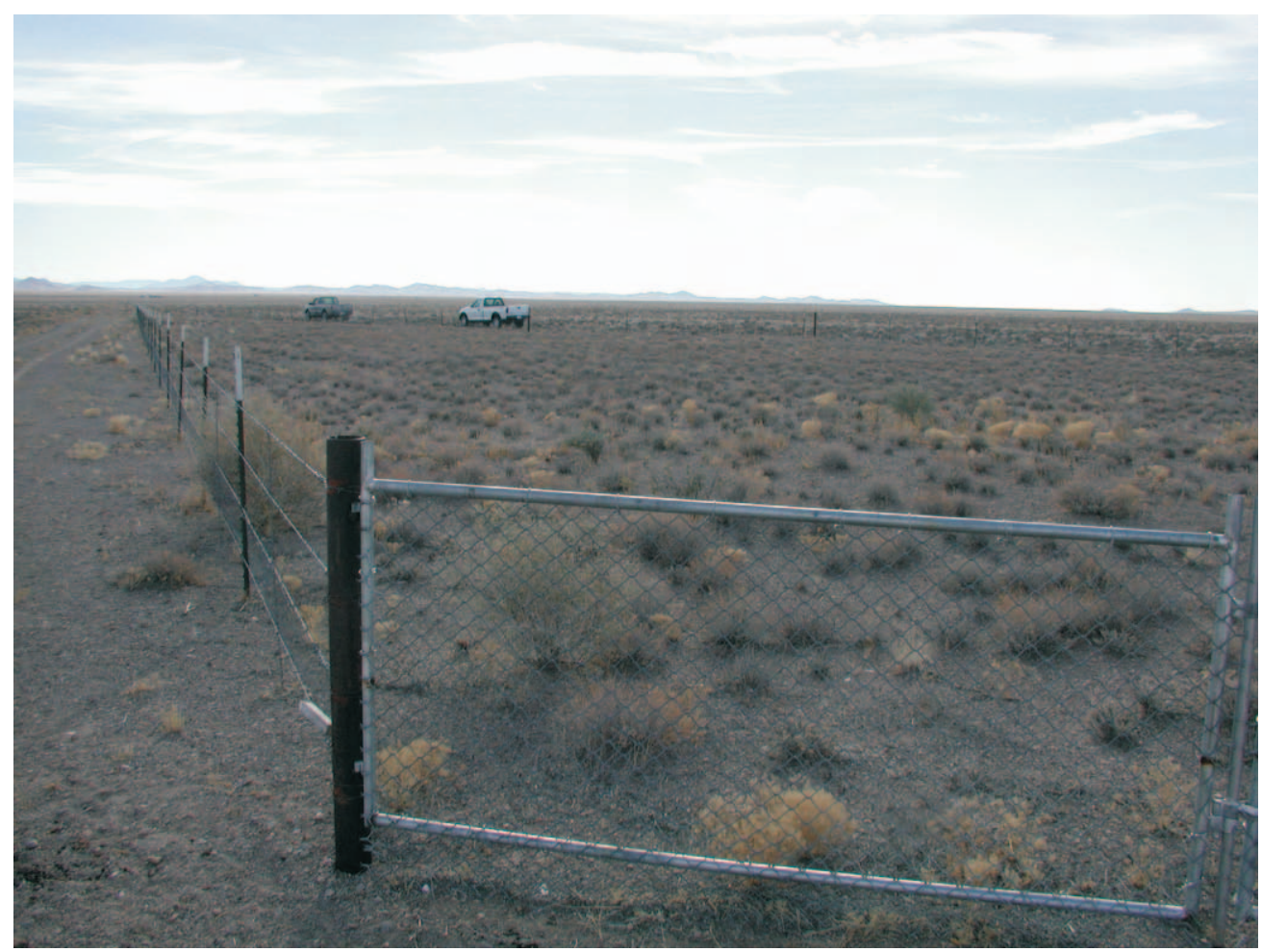

Photograph 2: CAU 400 Bomblet Pit, looking south, 11/15/2006 


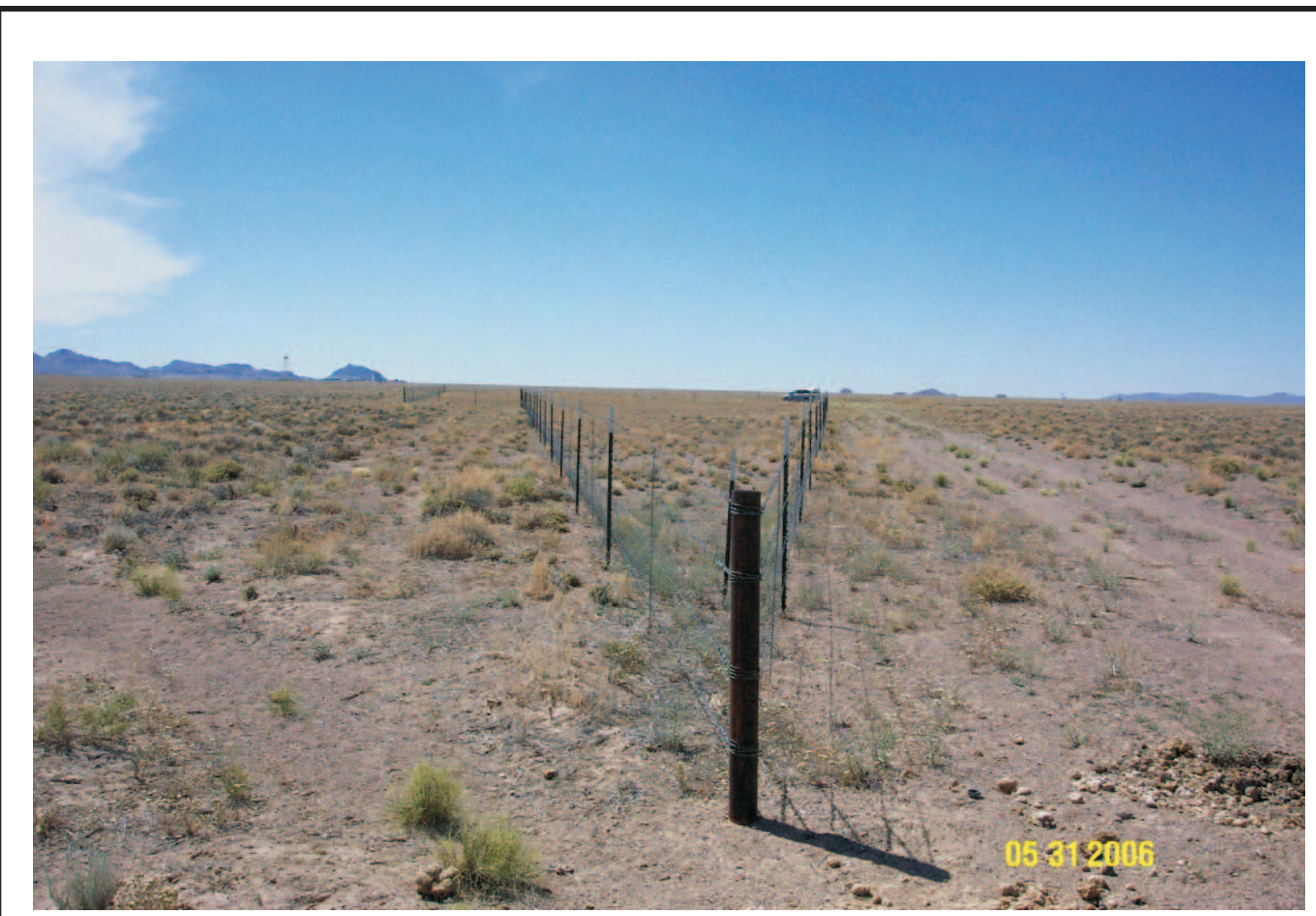

Photograph 3: CAU 400 Bomblet Pit, looking north, 05/31/2006

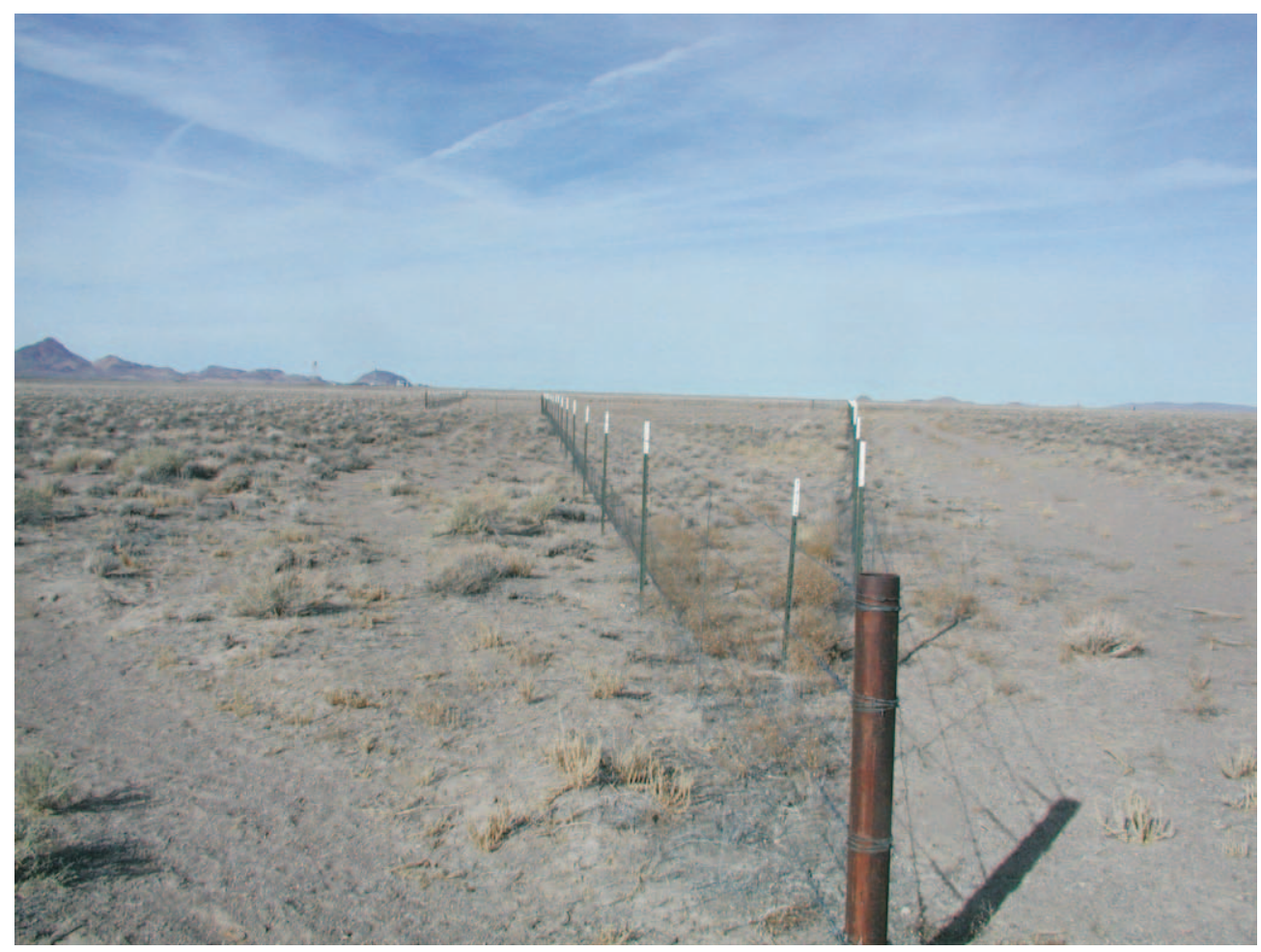

Photograph 4: CAU 400 Bomblet Pit, looking north, 11/15/2006 


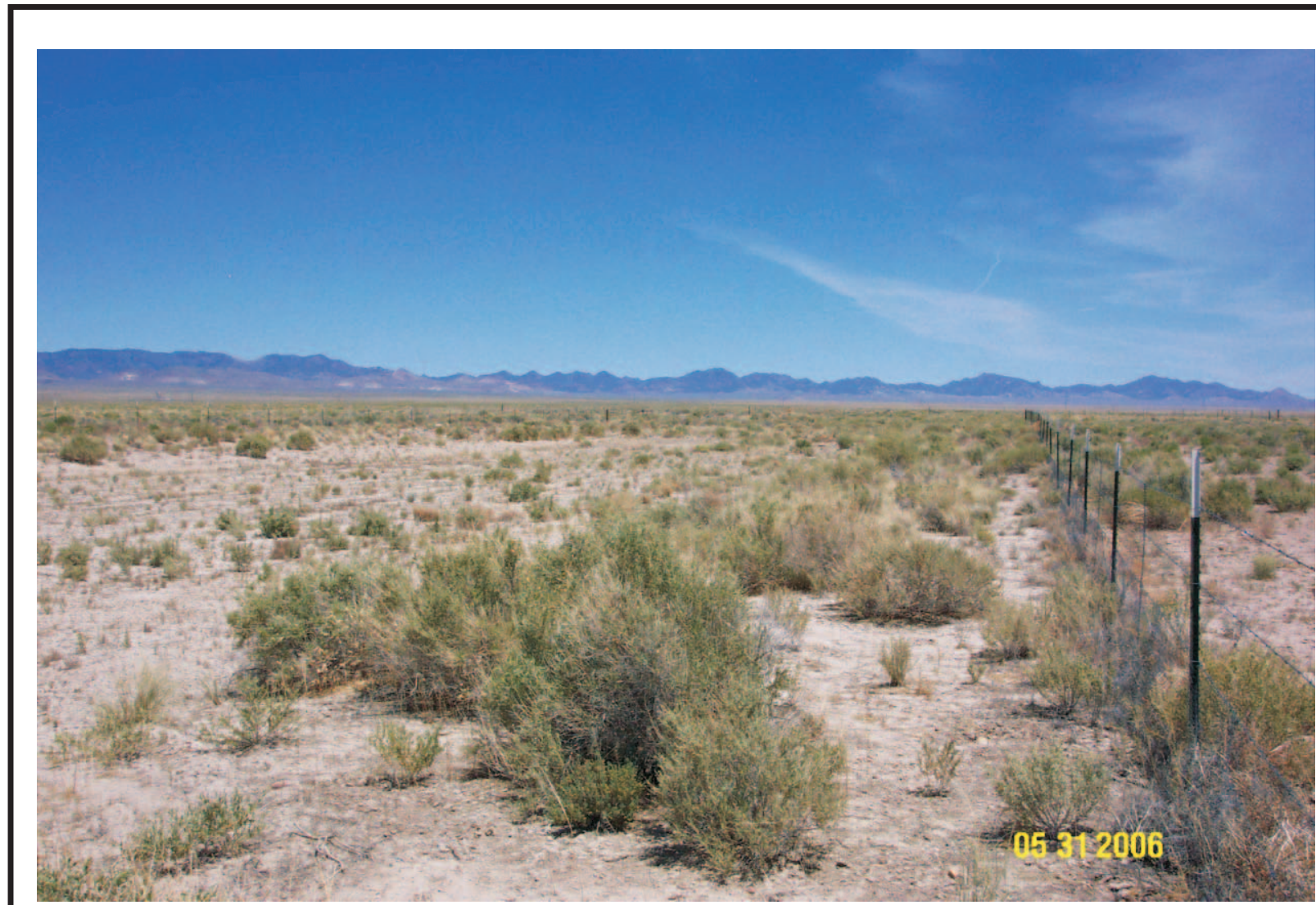

Photograph 5: CAU 400 Five Points Landfill, looking east, 05/31/2006

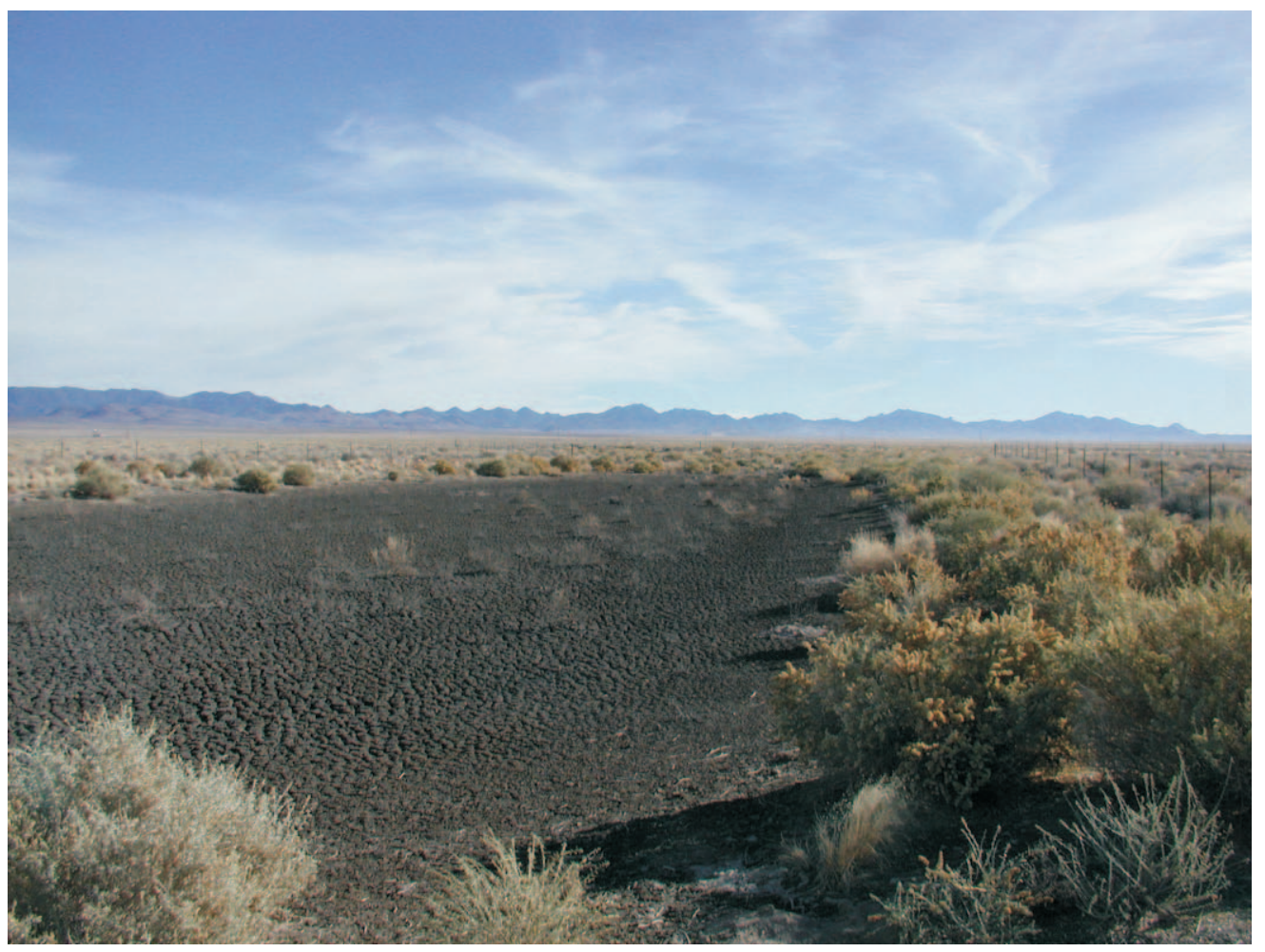

Photograph 6: CAU 400 Five Points Landfill, looking east, 11/15/2006 


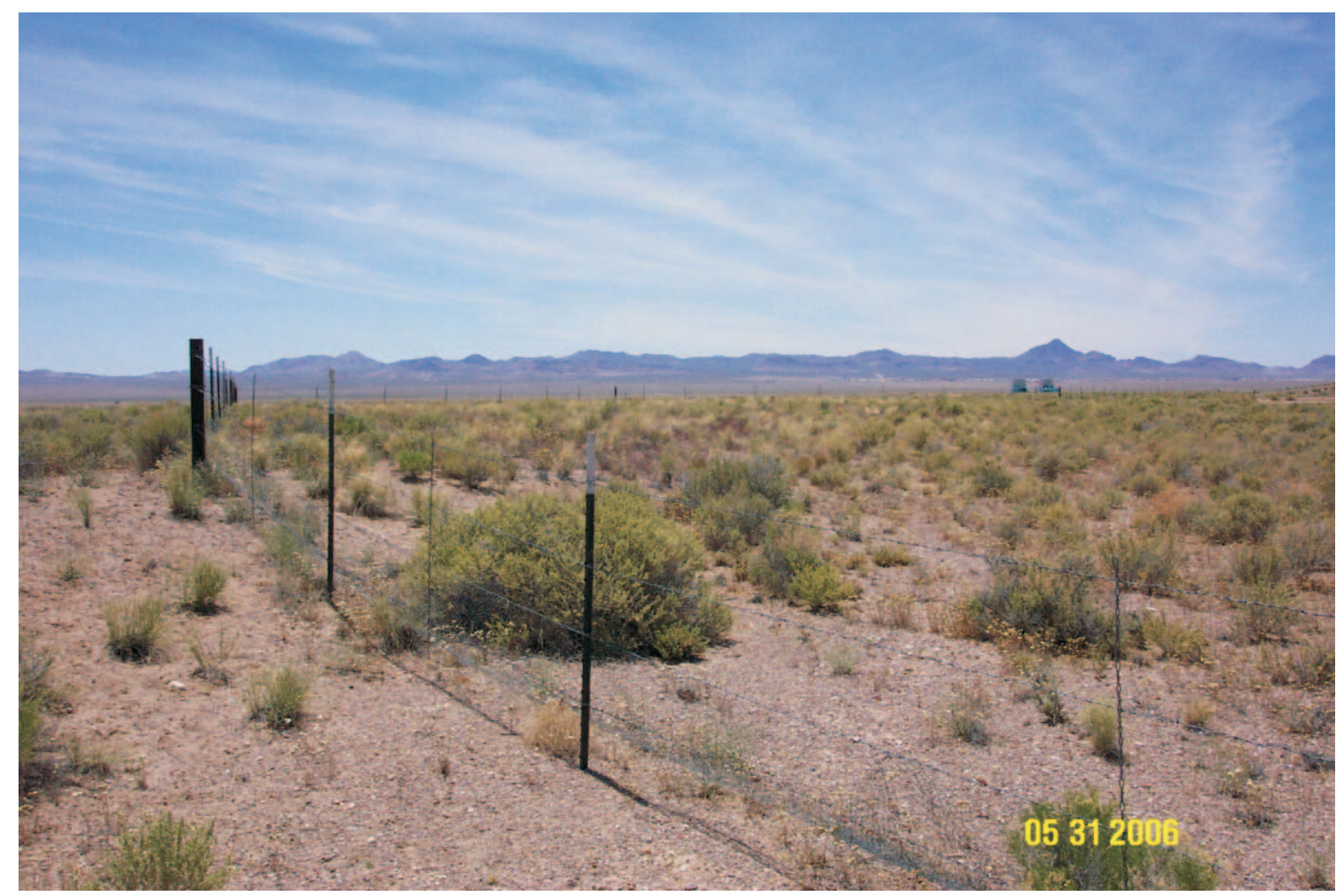

Photograph 7: CAU 400 Five Points Landfill, looking west, 05/31/2006

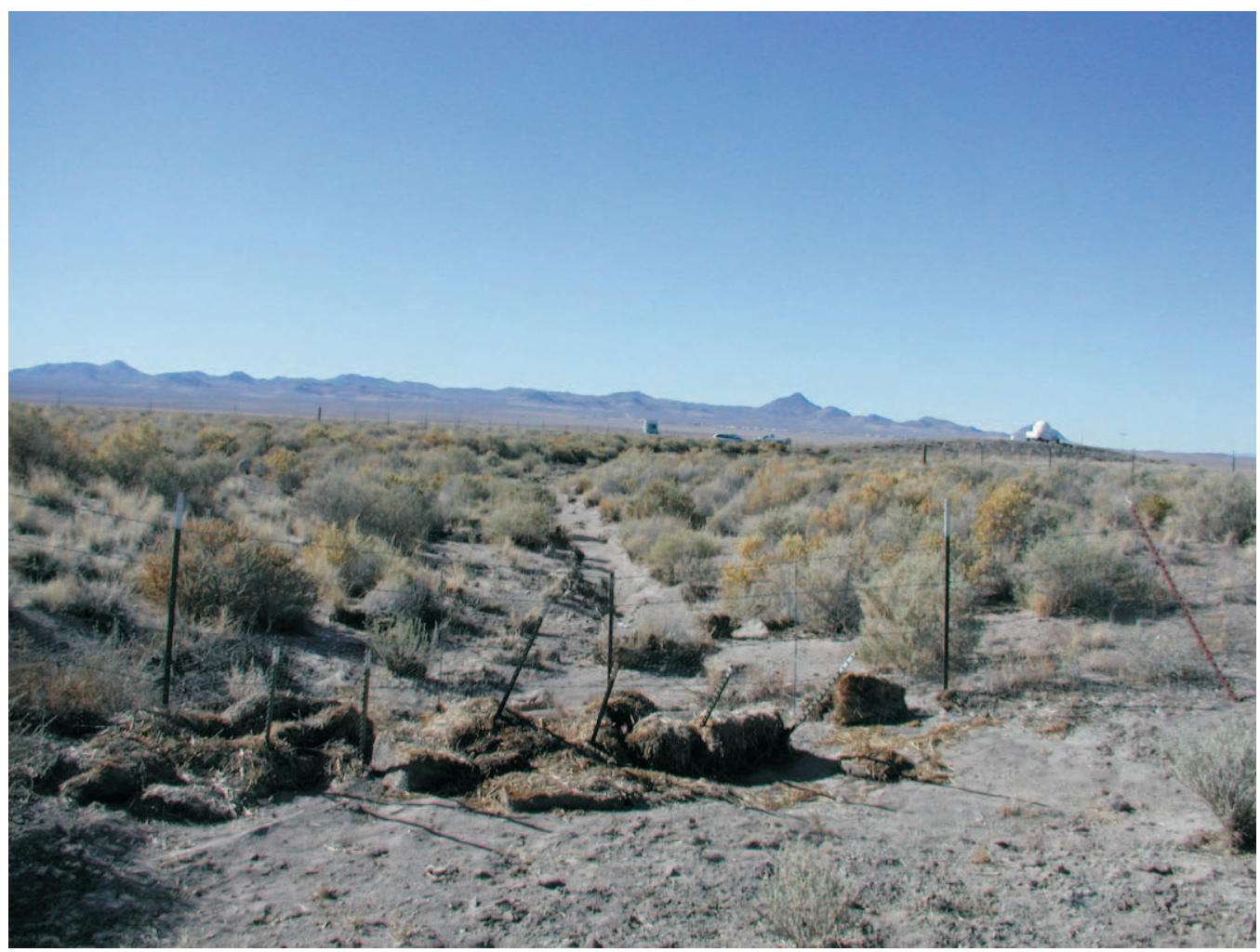

Photograph 8: CAU 400 Five Points Landfill, looking west, 11/15/2006 


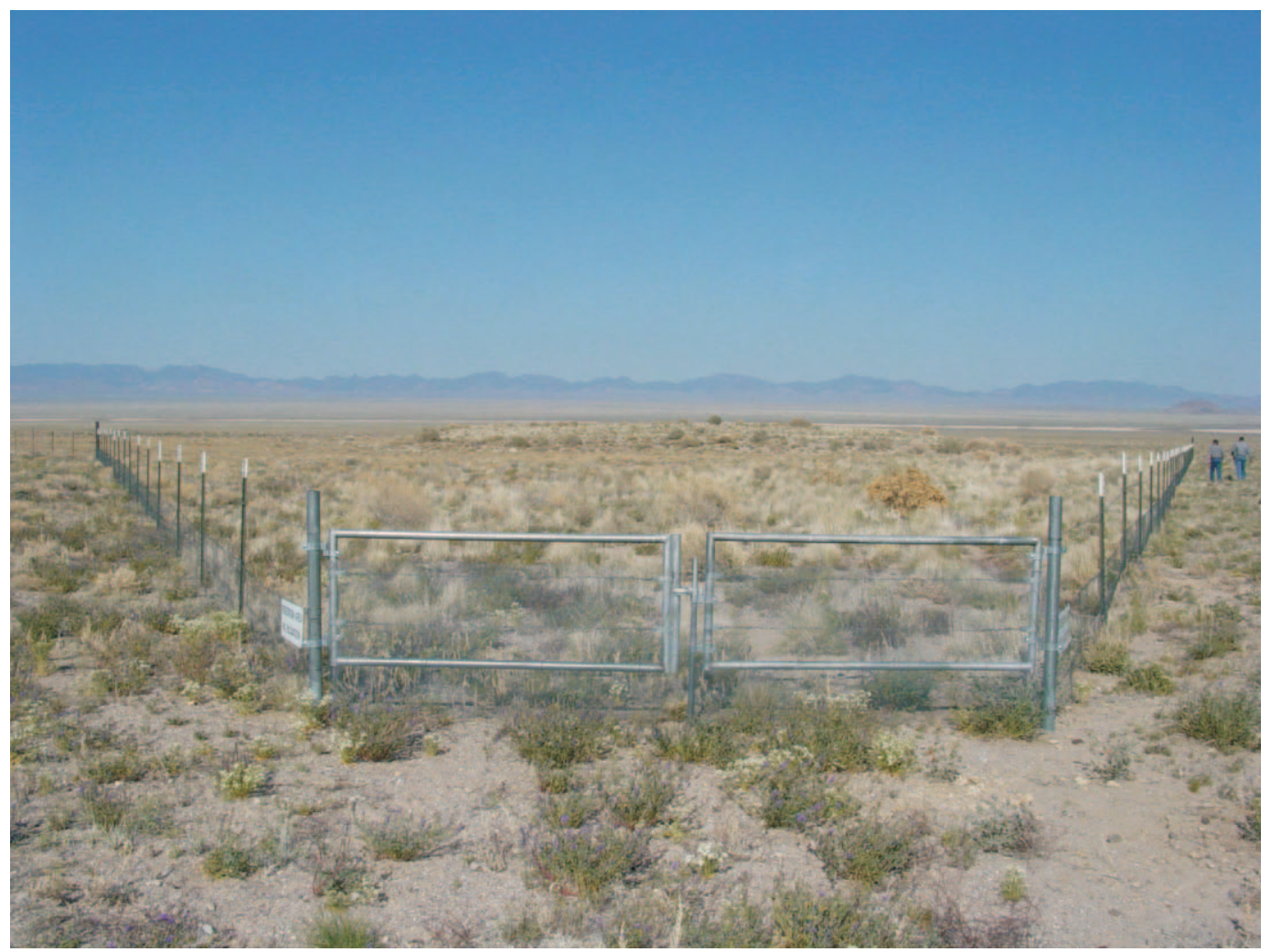

Photograph 9: CAU 404, looking east, 05/09/2006

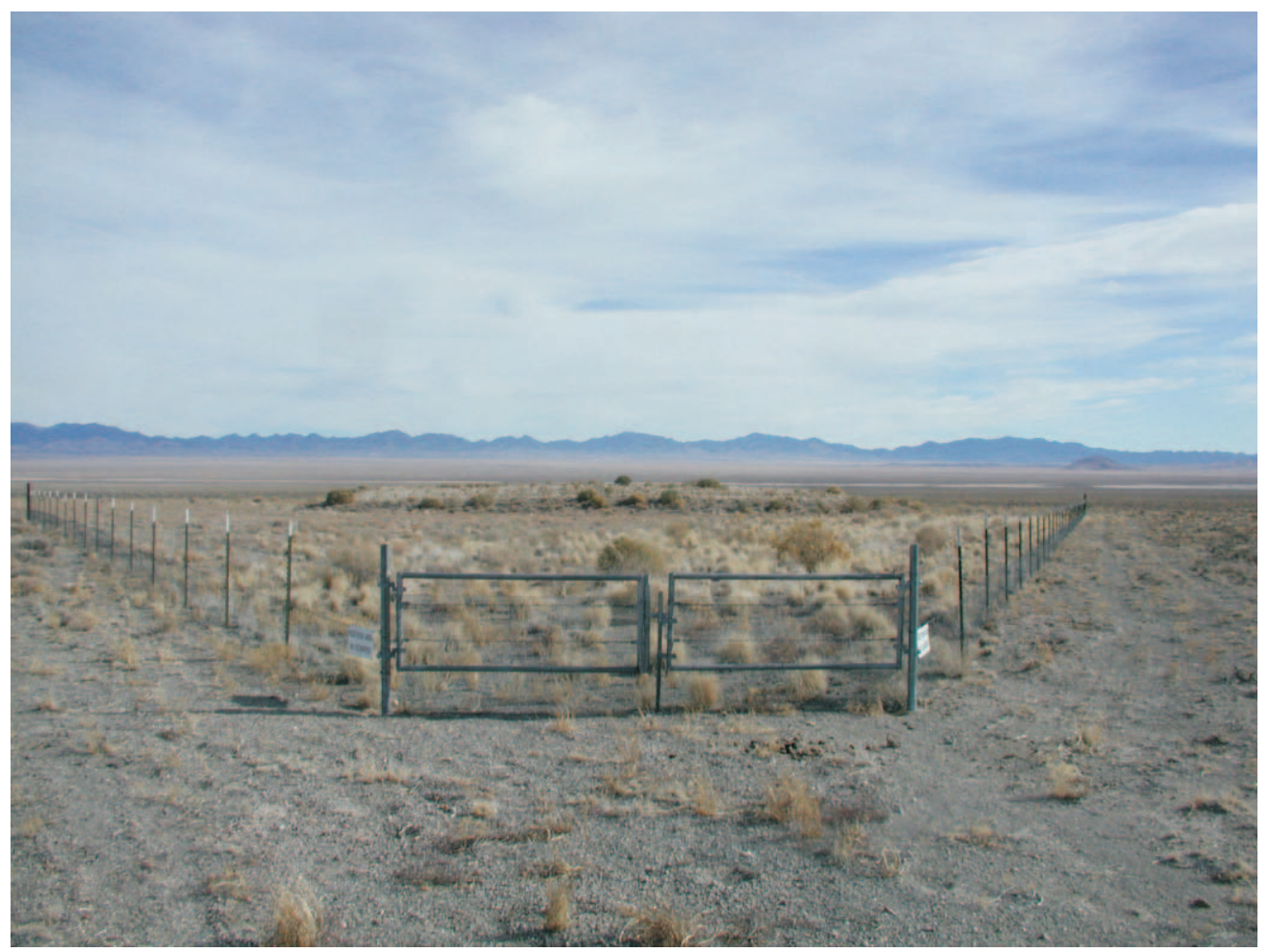

Photograph 10: CAU 404, looking east, 11/15/2006 


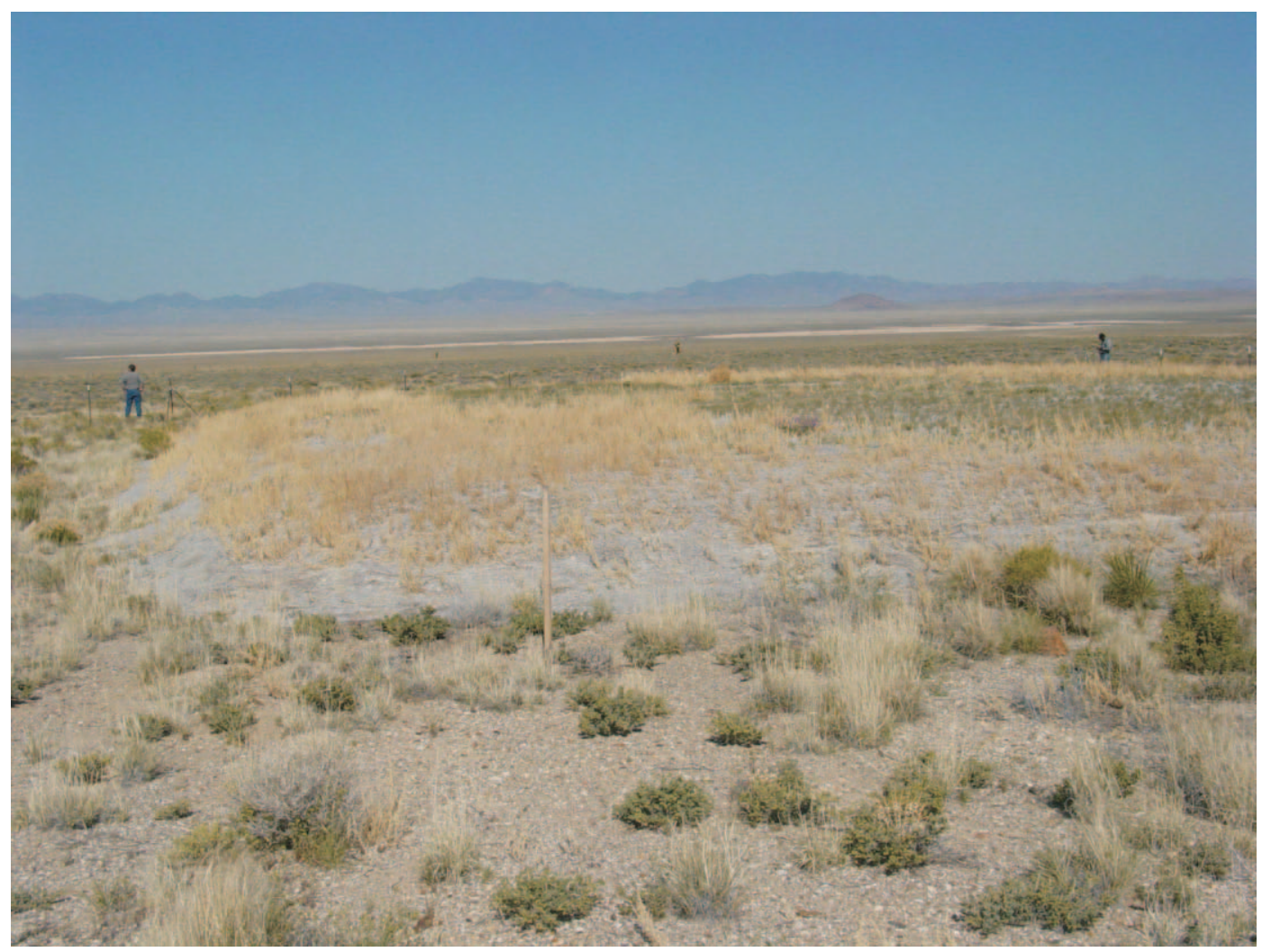

Photograph 11: CAU 407, looking east, 05/09/2006

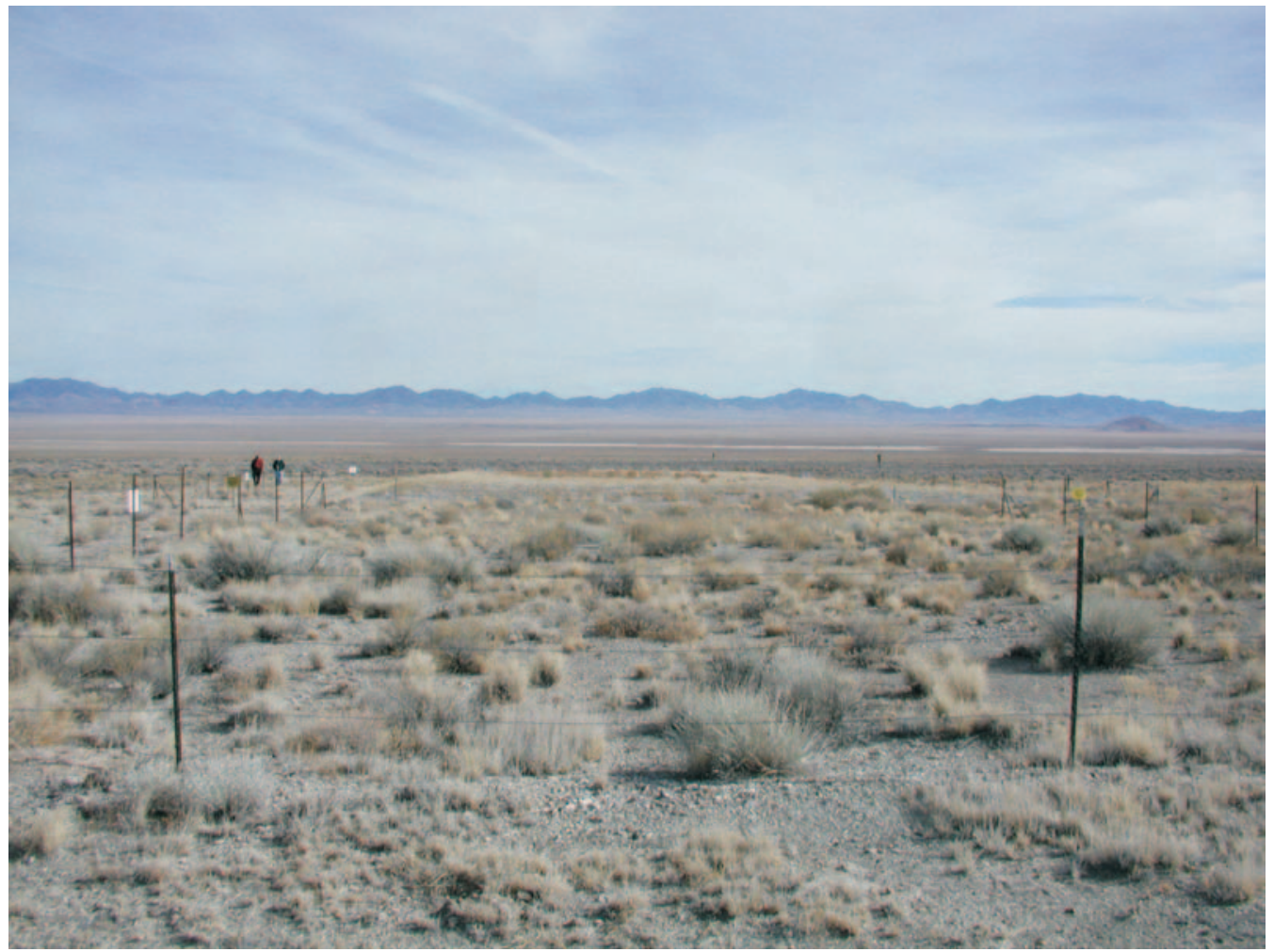

Photograph 12: CAU 407, looking east, 11/15/2006 


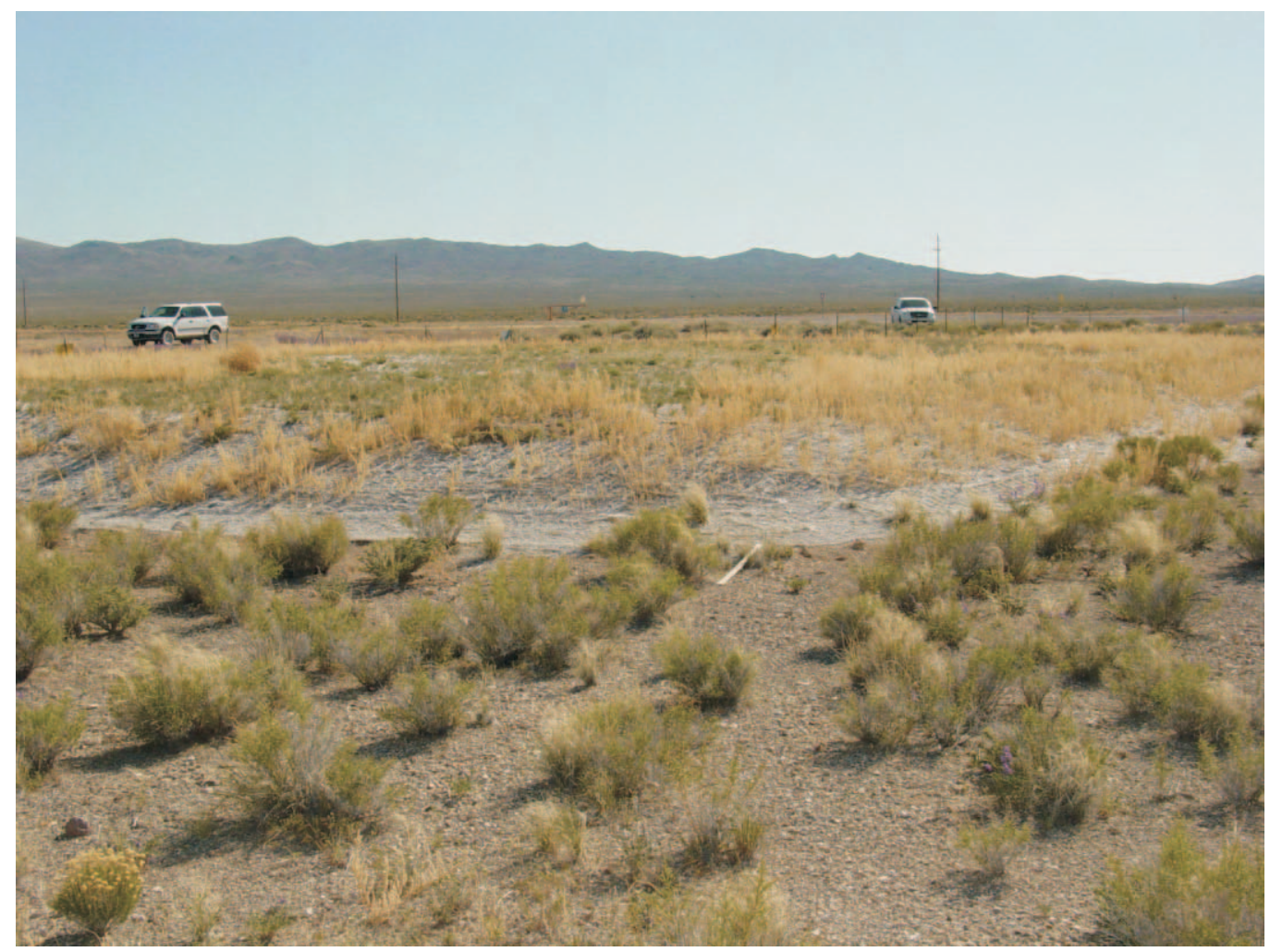

Photograph 13: CAU 407, looking southwest, 05/09/2006

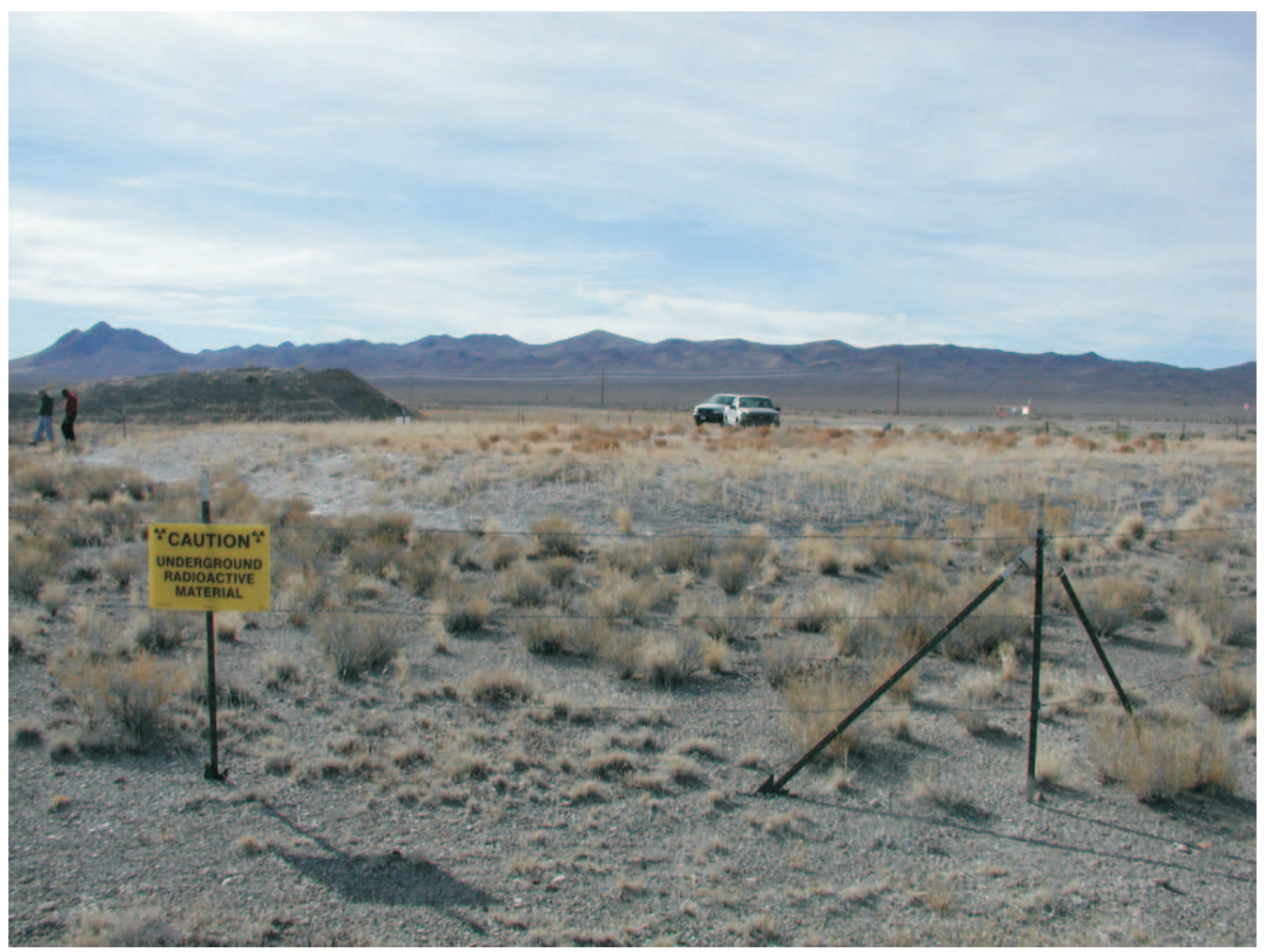

Photograph 14: CAU 407, looking northeast, 11/15/2006 


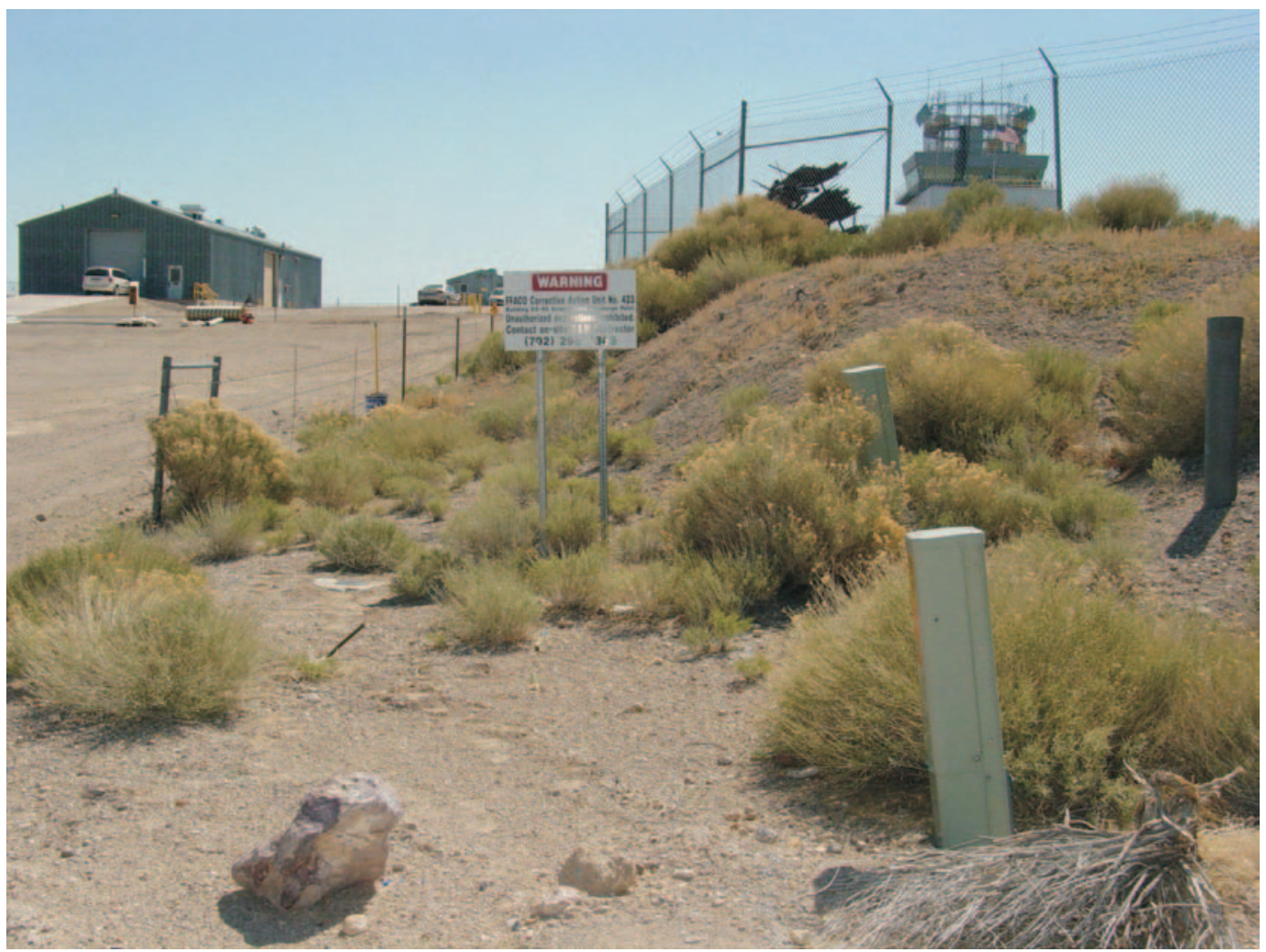

Photograph 15: CAU 423, looking east, 05/09/2006

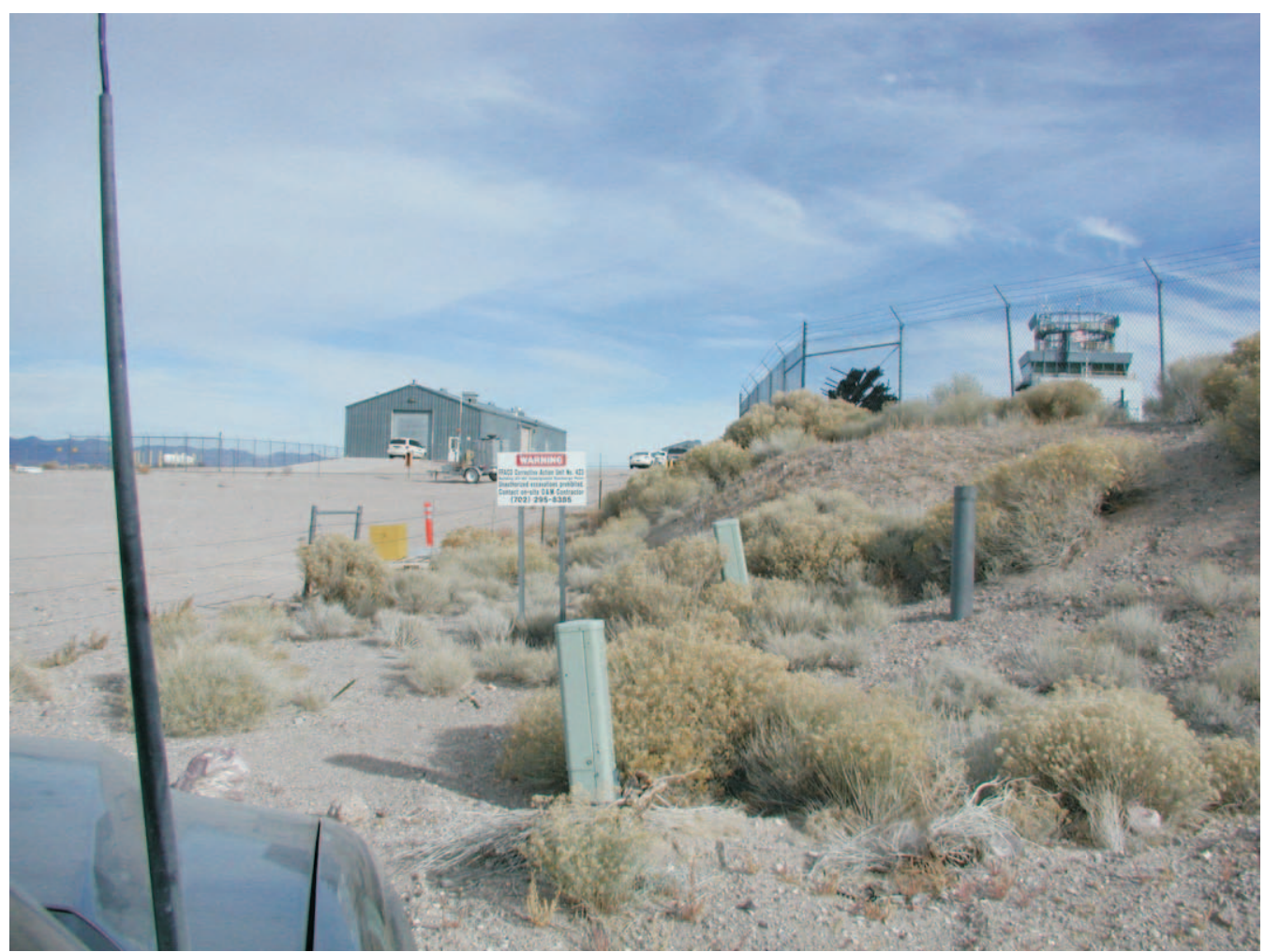

Photograph 16: CAU 423, looking east, 11/15/2006 


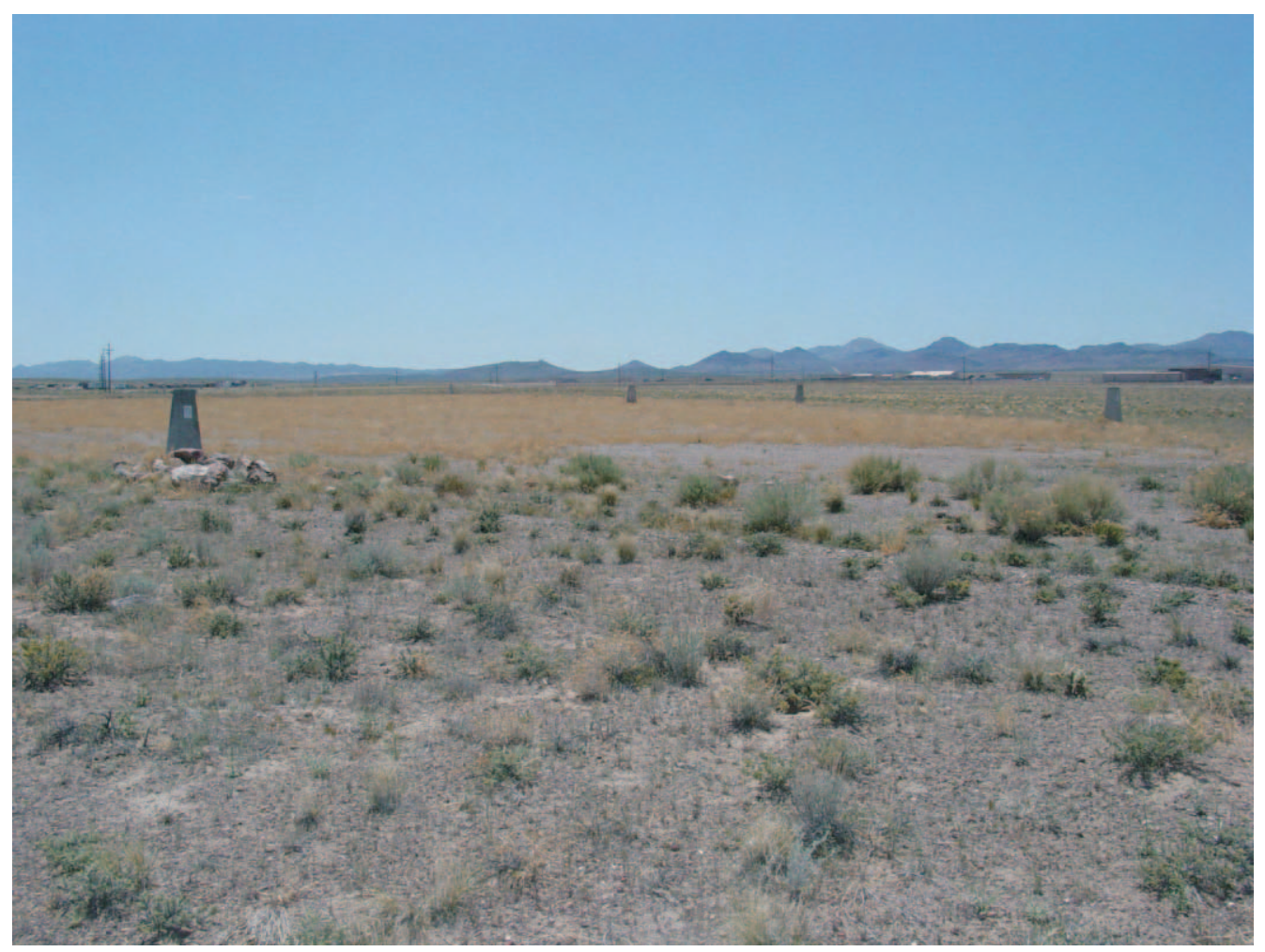

Photograph 17: CAU 424, Landfill Cell A3-1, looking south, 05/09/2006

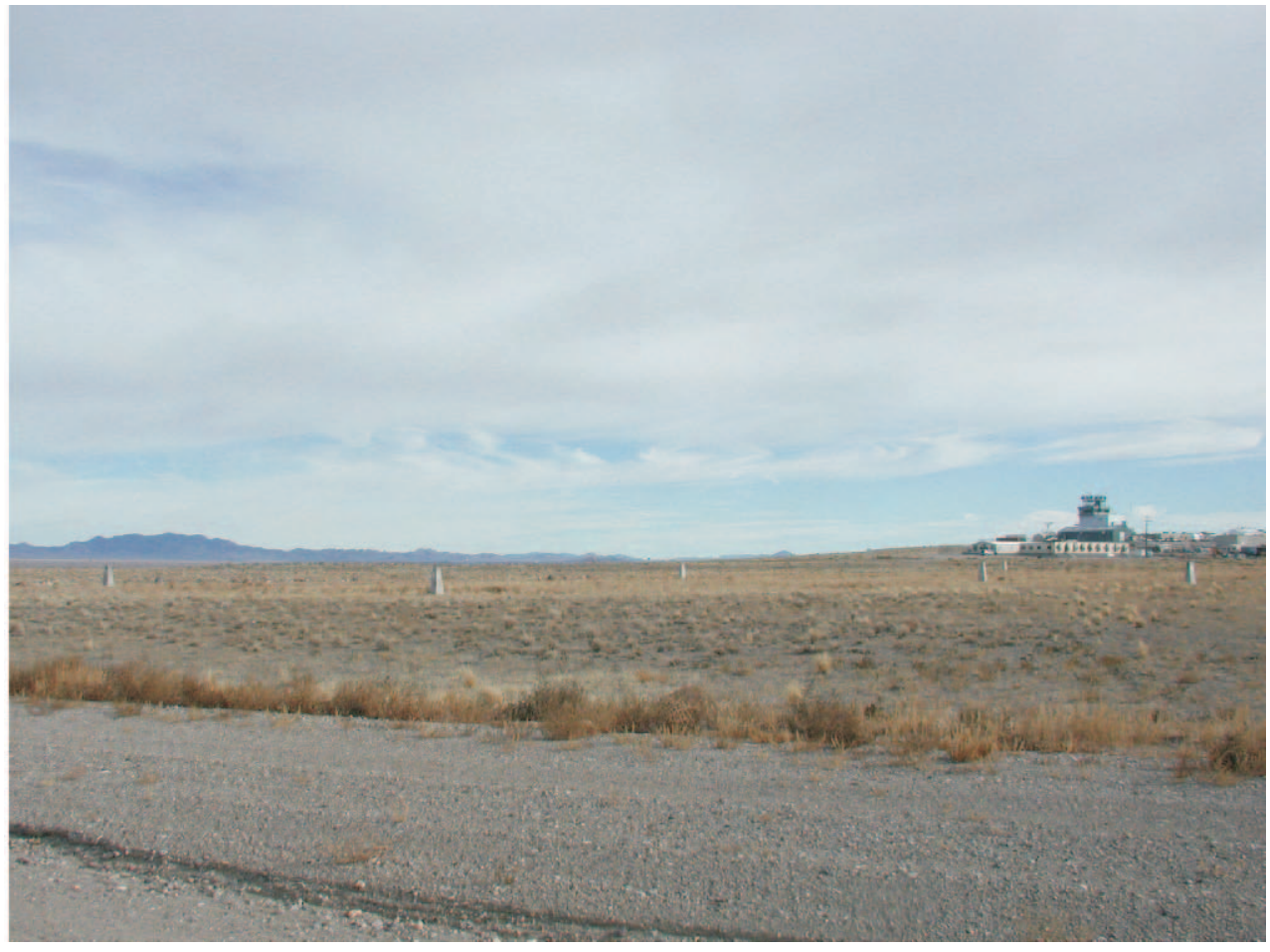

Photograph 18: CAU 424, Landfill Cell A3-1, looking north, 11/15/2006 


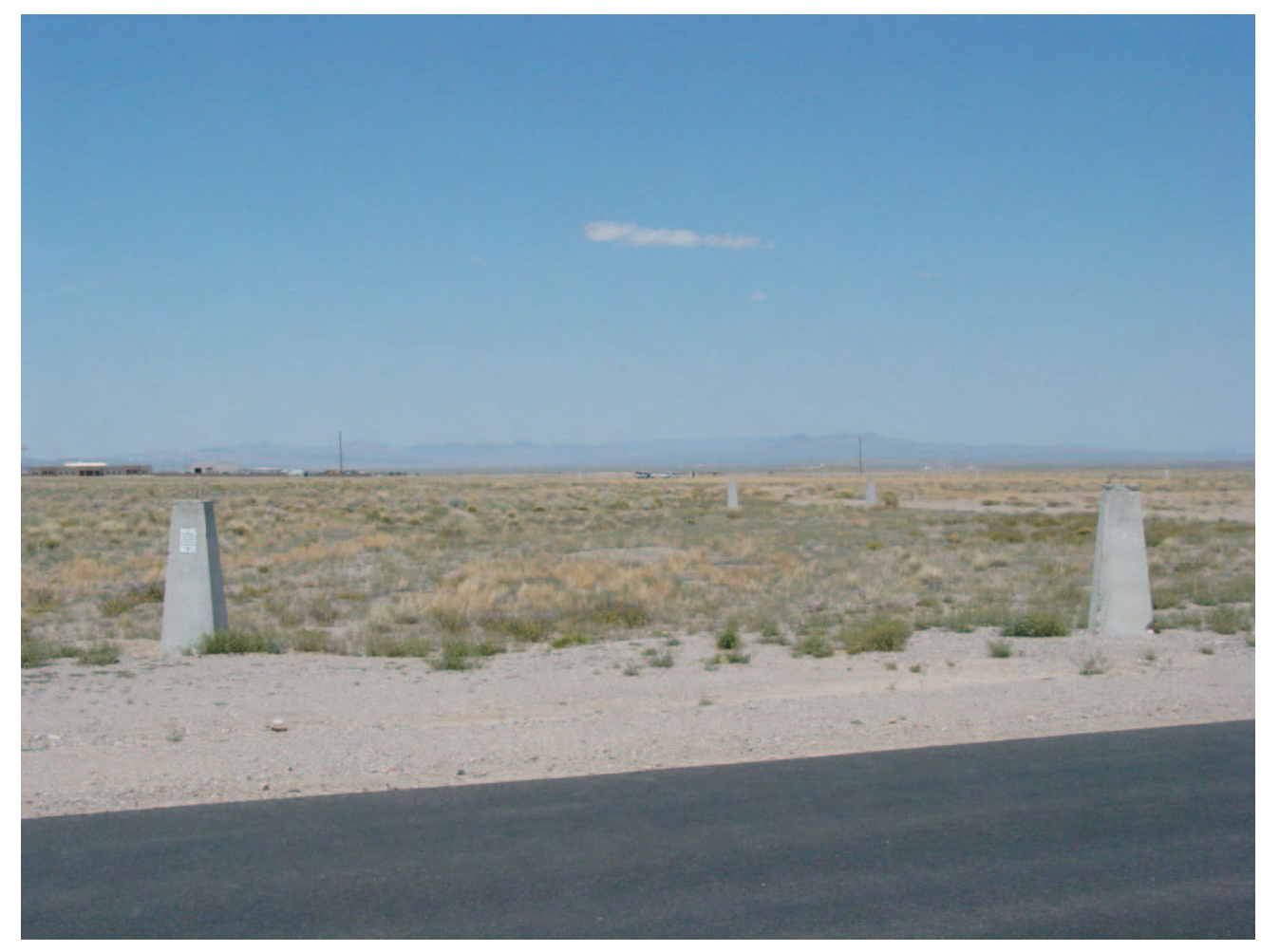

Photograph 19: CAU 424, Landfill Cell A3-2, looking north, 05/09/2006

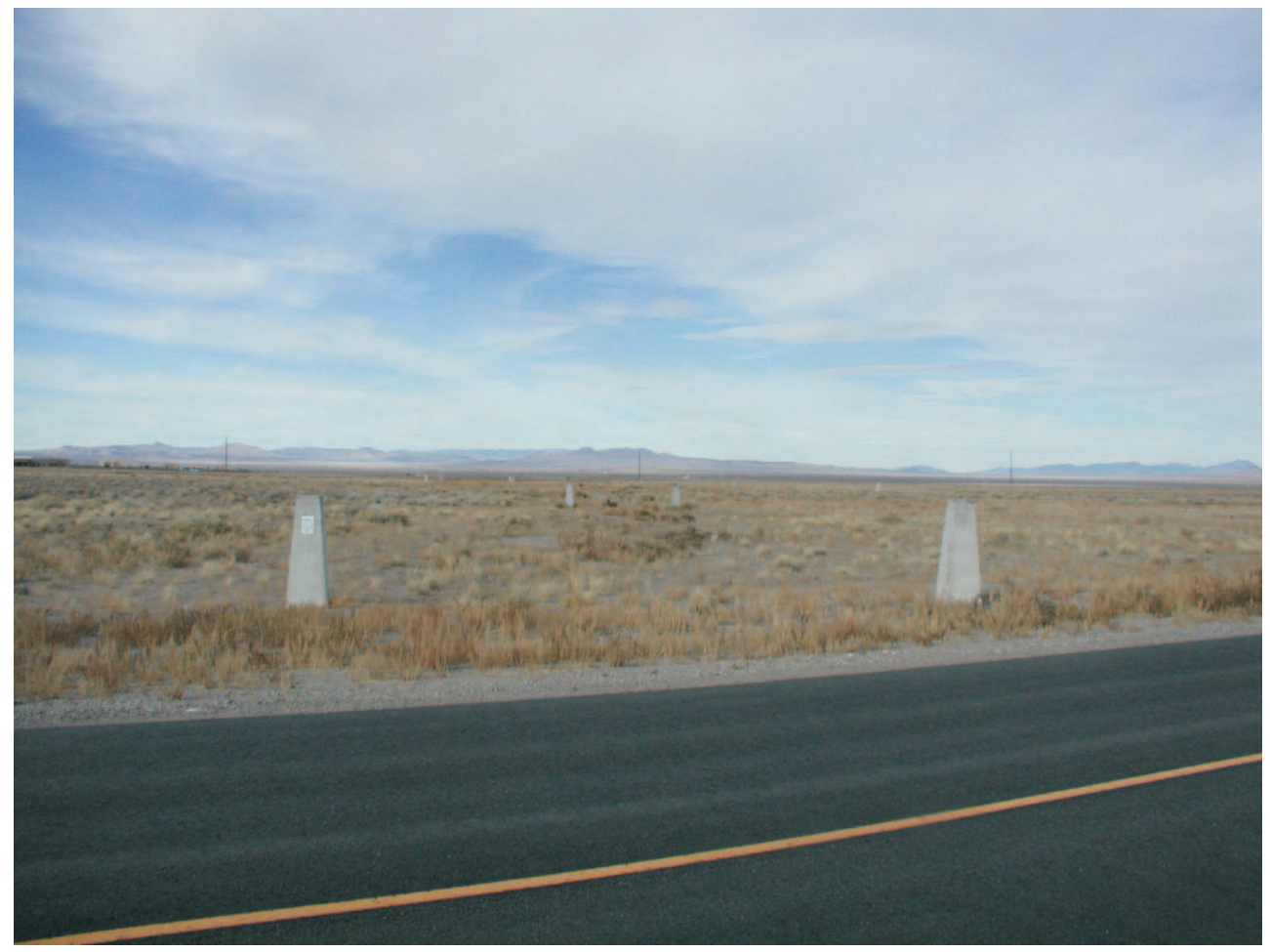

Photograph 20: CAU 424, Landfill Cell A3-2, looking north, 11/15/2006 


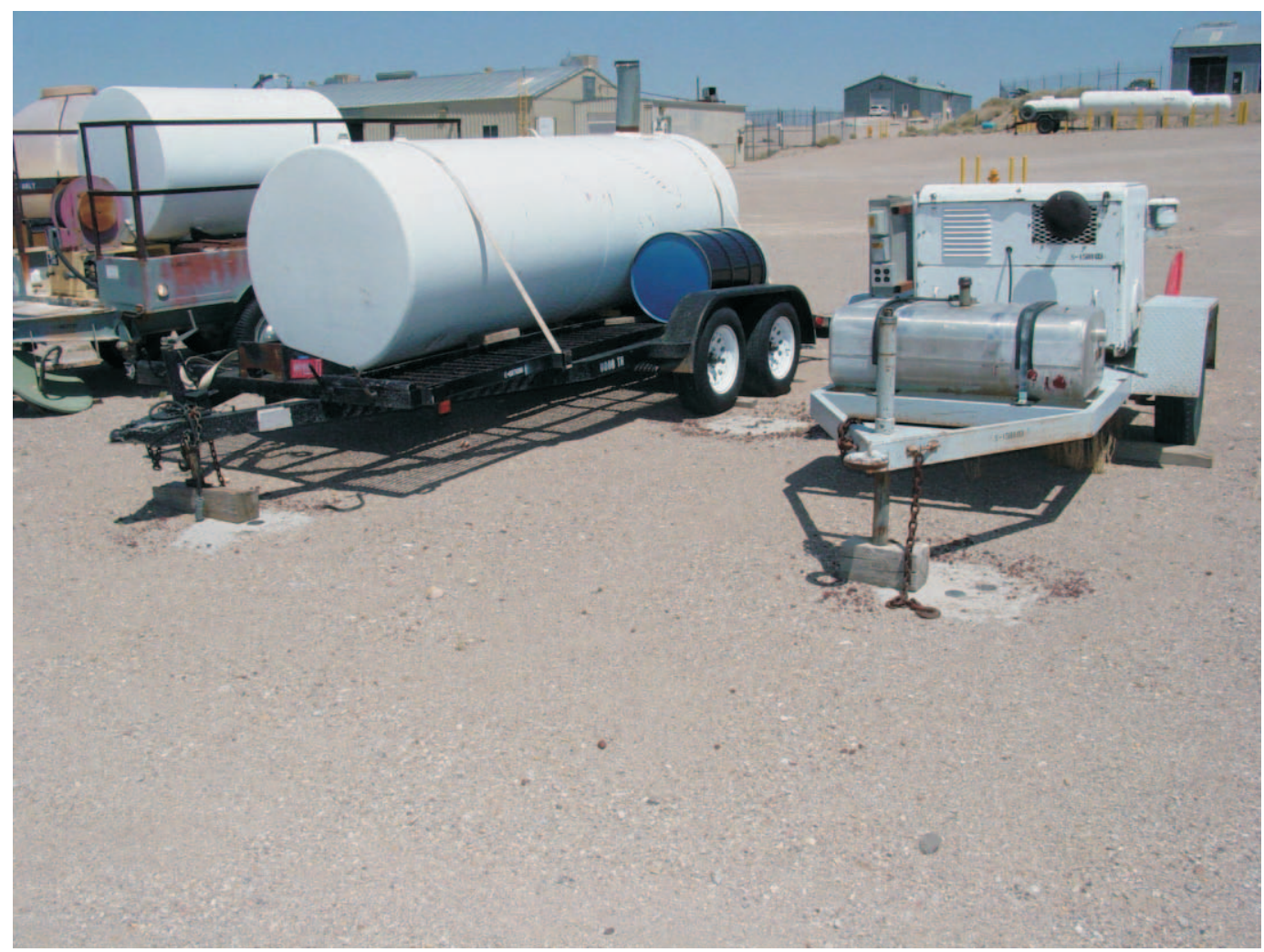

Photograph 21: CAU 424, Landfill Cell A3-3, looking east, 05/09/2006

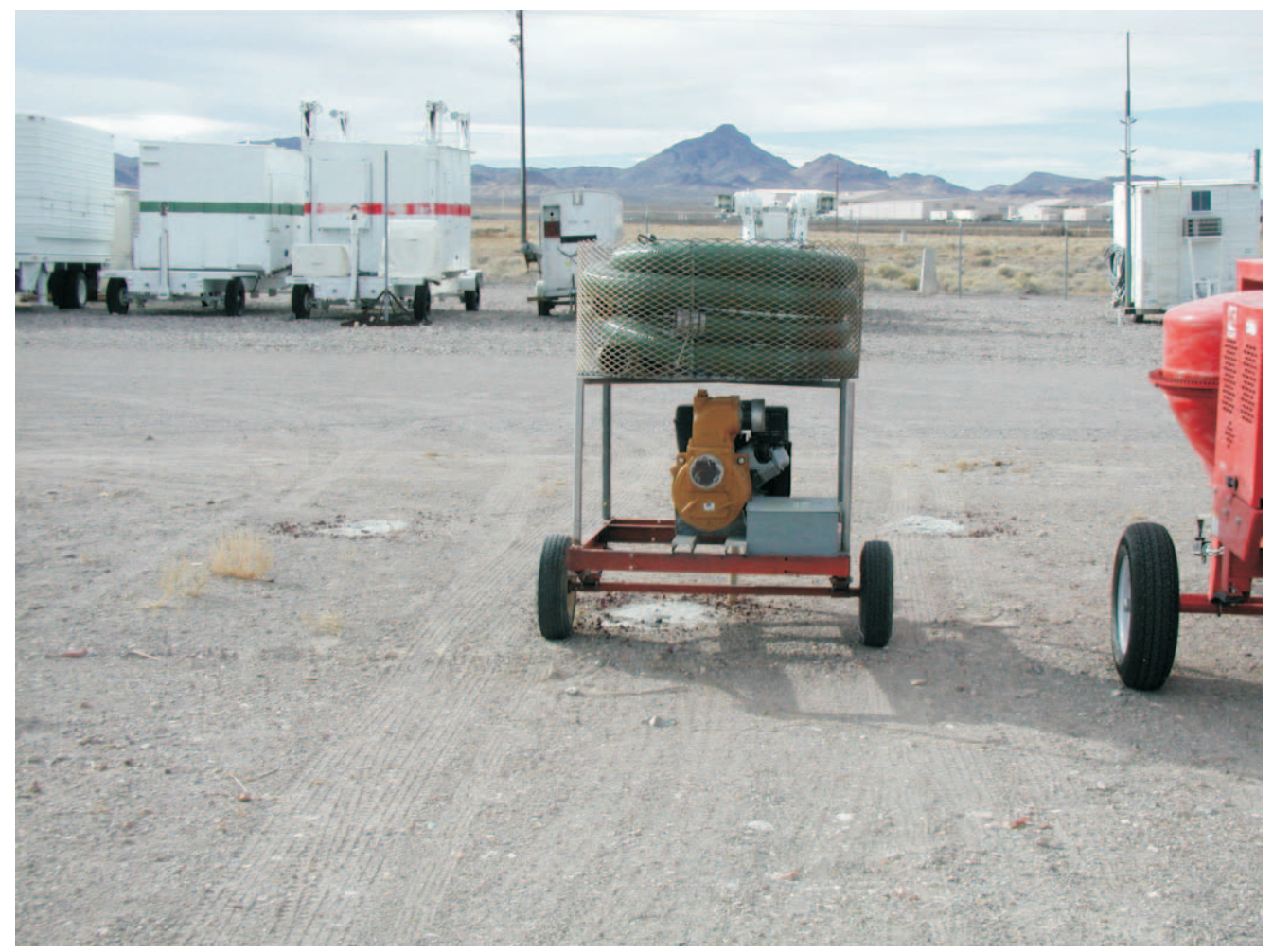

Photograph 22: CAU 424, Landfill Cell A3-3, looking west, 11/15/2006 


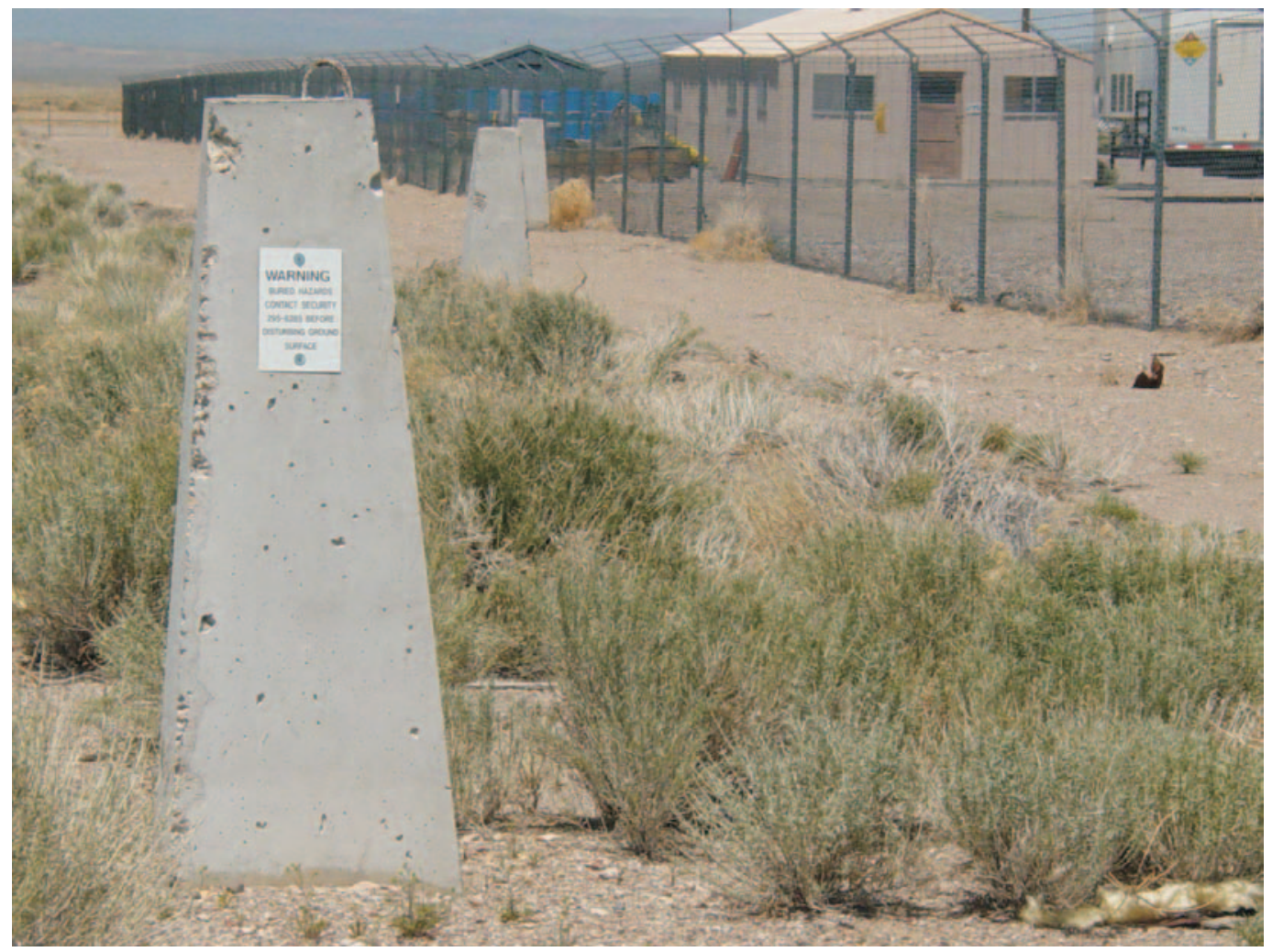

Photograph 23: CAU 424, Landfill Cell A3-3, looking north, 05/09/2006

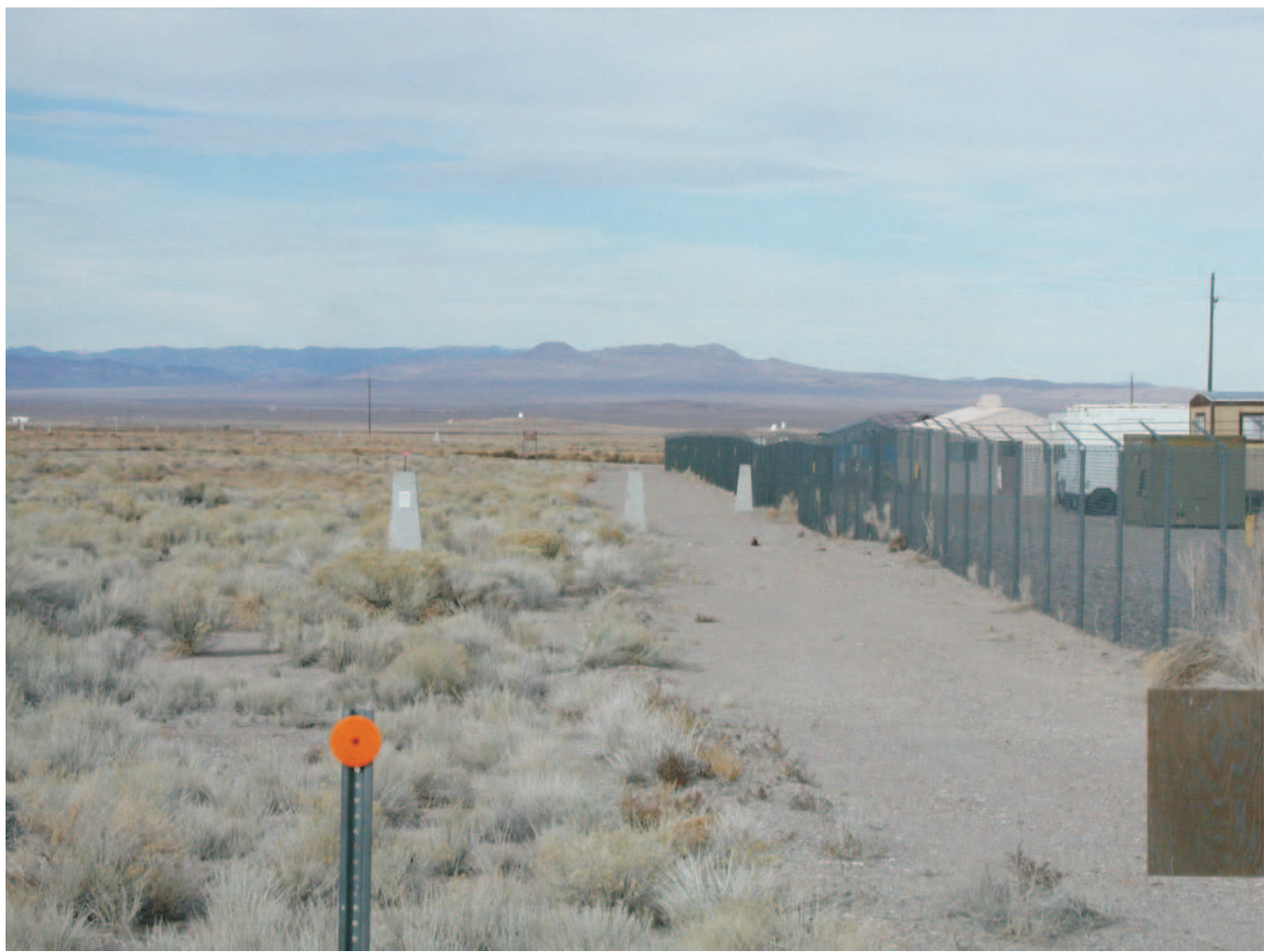

Photograph 24: CAU 424, Landfill Cell A3-3, looking north, 11/15/2006 


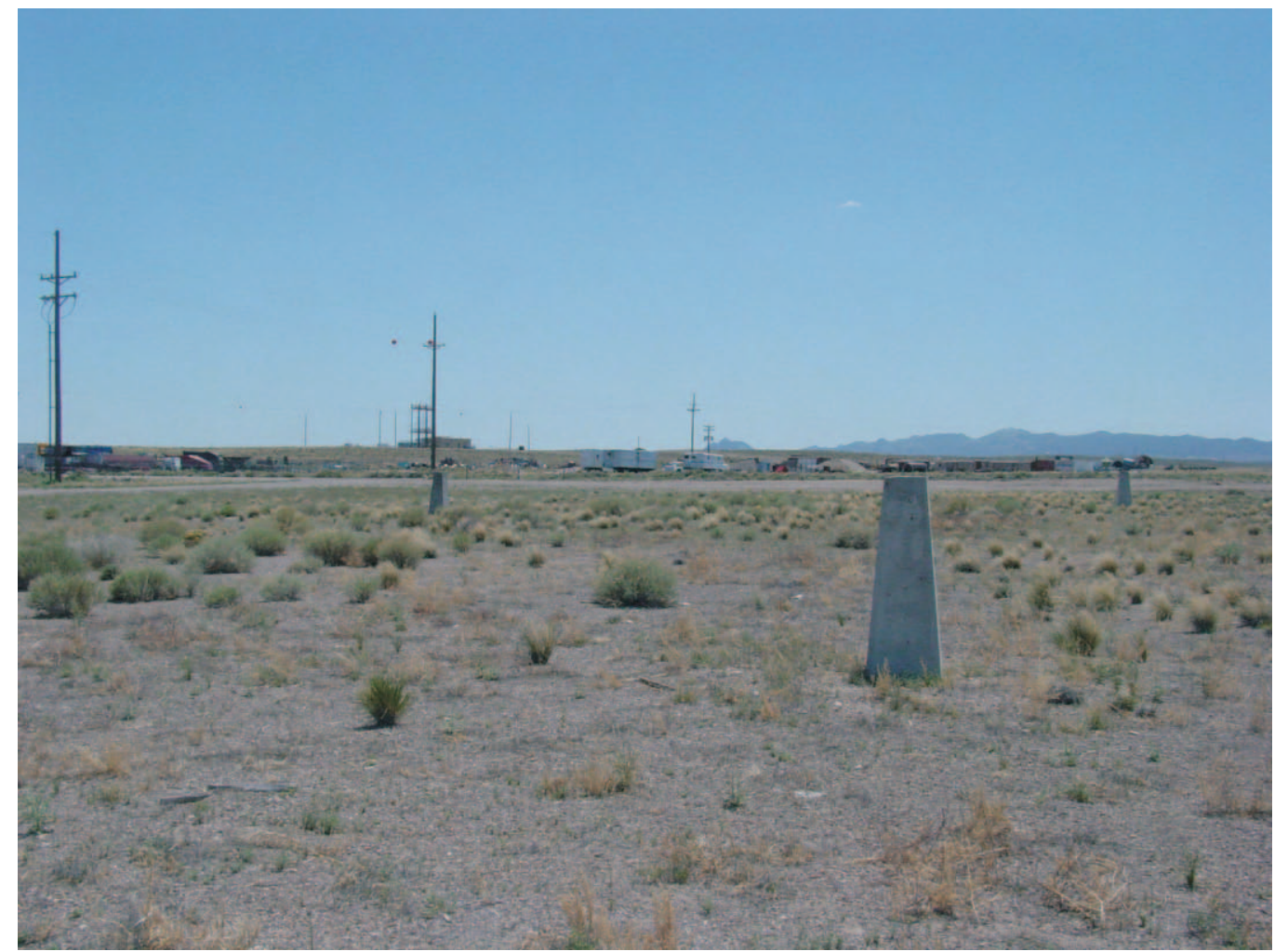

Photograph 25: CAU 424, Landfill Cell A3-4, looking northeast, 05/09/2006

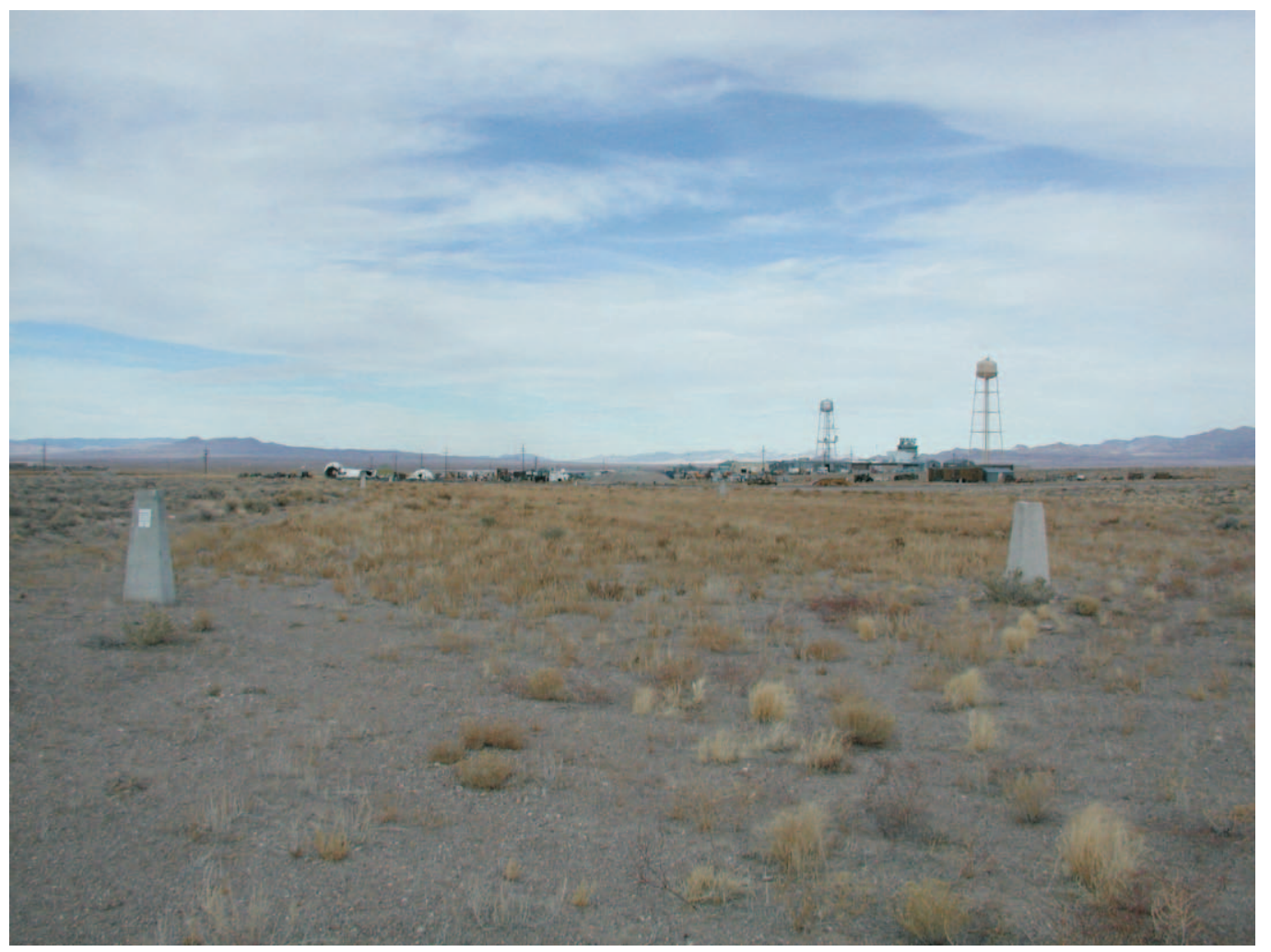

Photograph 26: CAU 424, Landfill Cell A3-4, looking north, 11/15/2006 


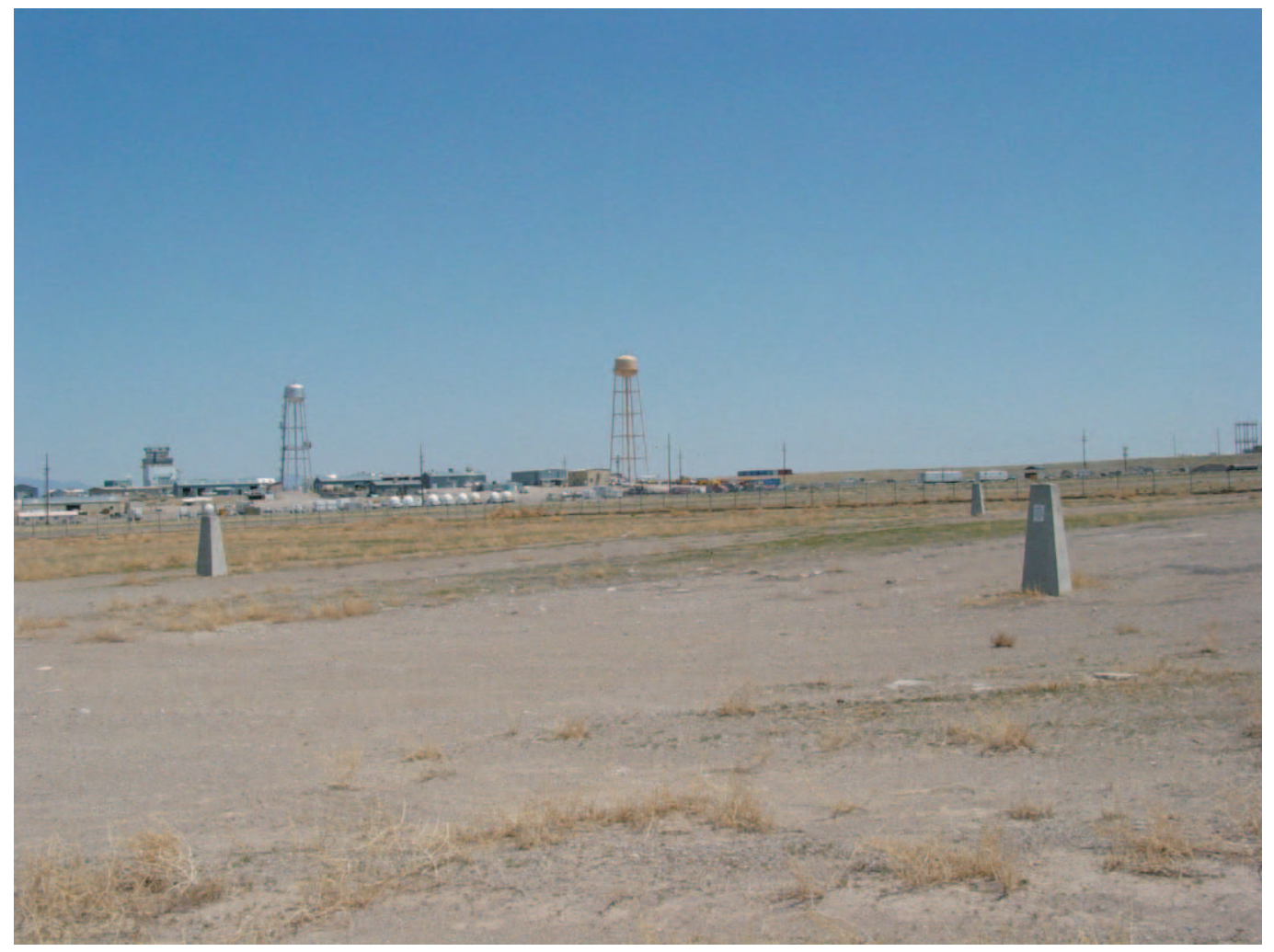

Photograph 27: CAU 424, Landfill Cell A3-5, looking southeast, 05/09/2006

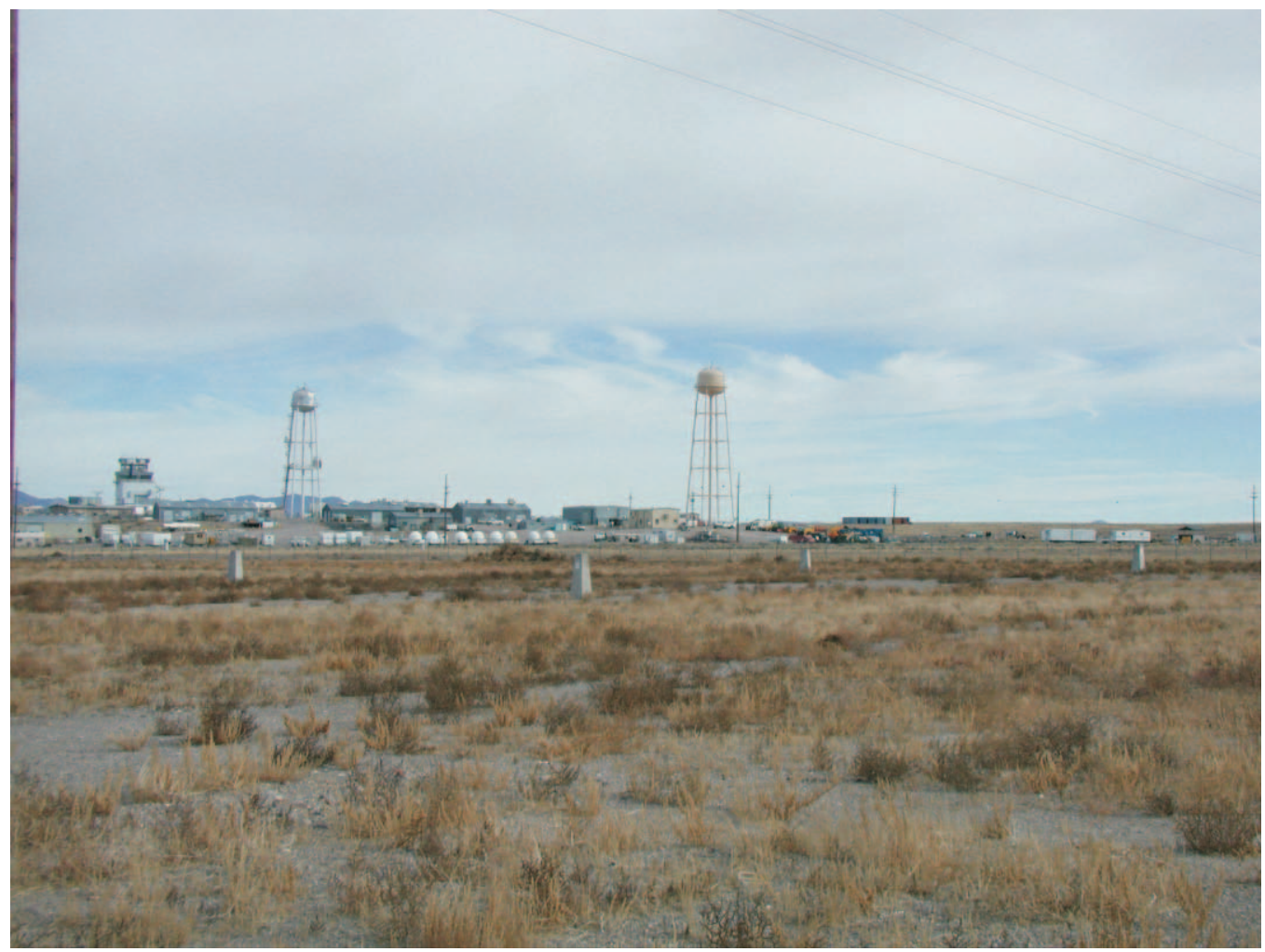

Photograph 28: CAU 424, Landfill Cell A3-5, looking southeast, 11/15/2006 


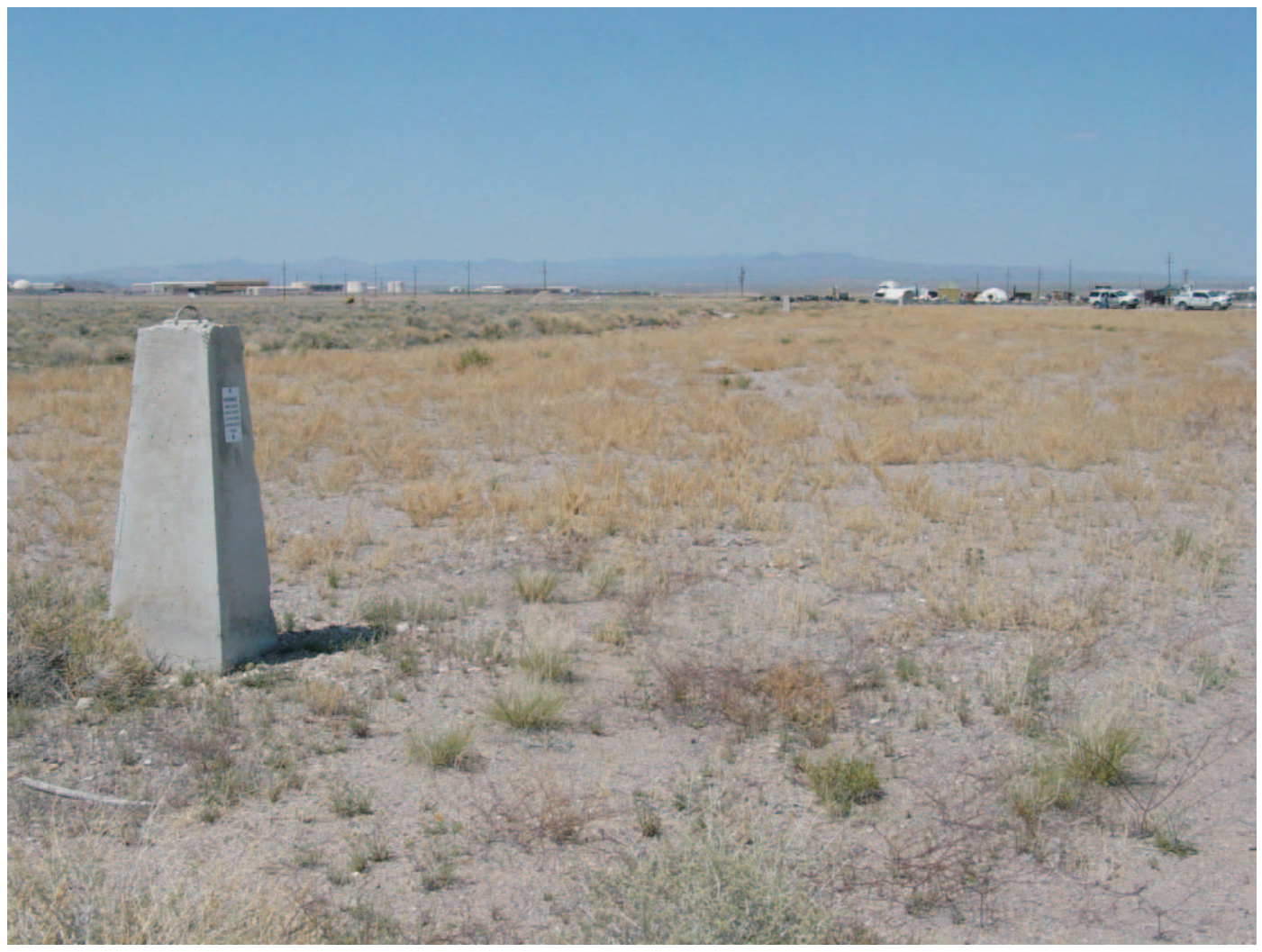

Photograph 29: CAU 424, Landfill Cell A3-6, looking northwest, 05/09/2006

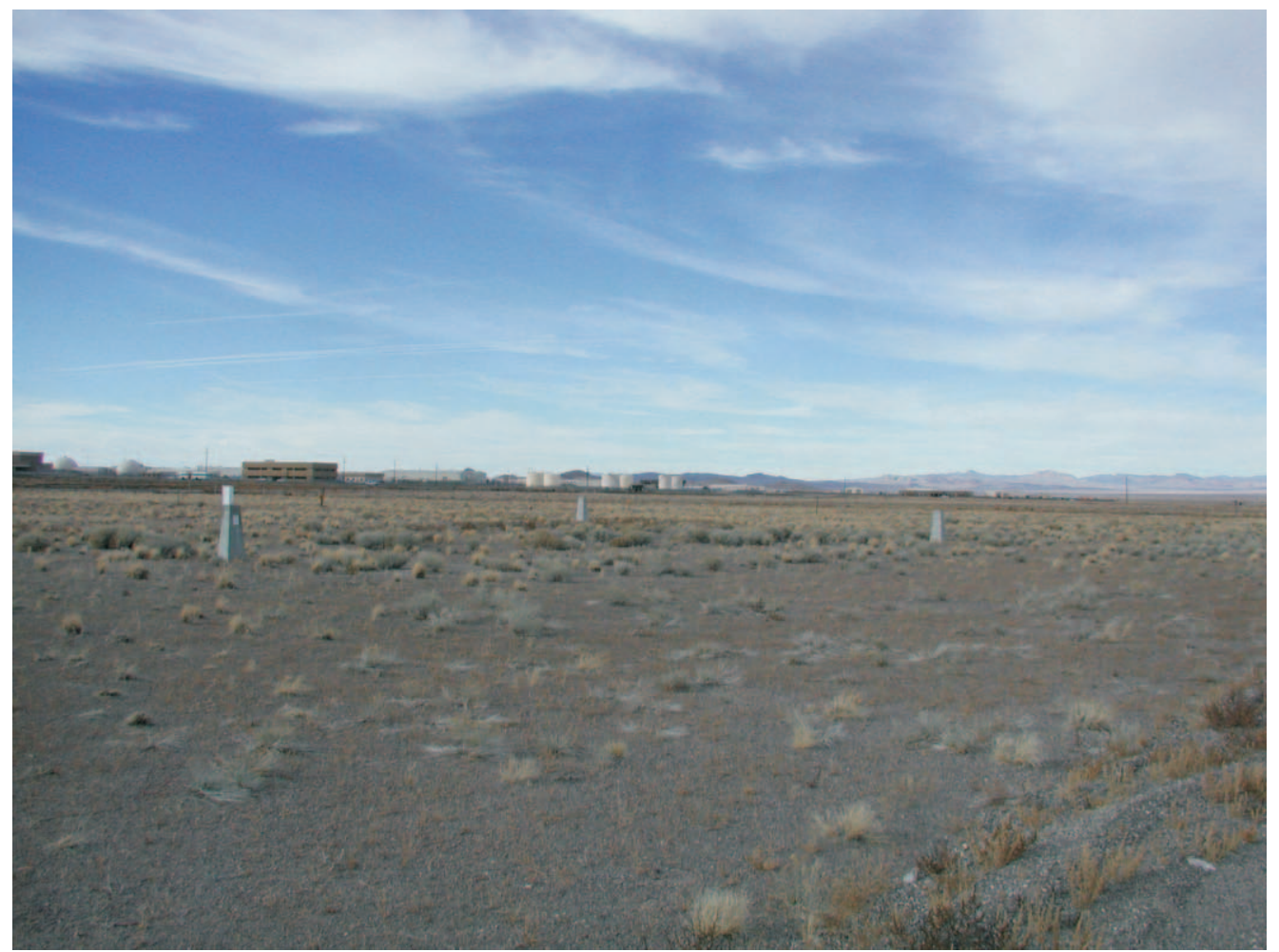

Photograph 30: CAU 424, Landfill Cell A3-6, looking northwest, 11/15/2006 


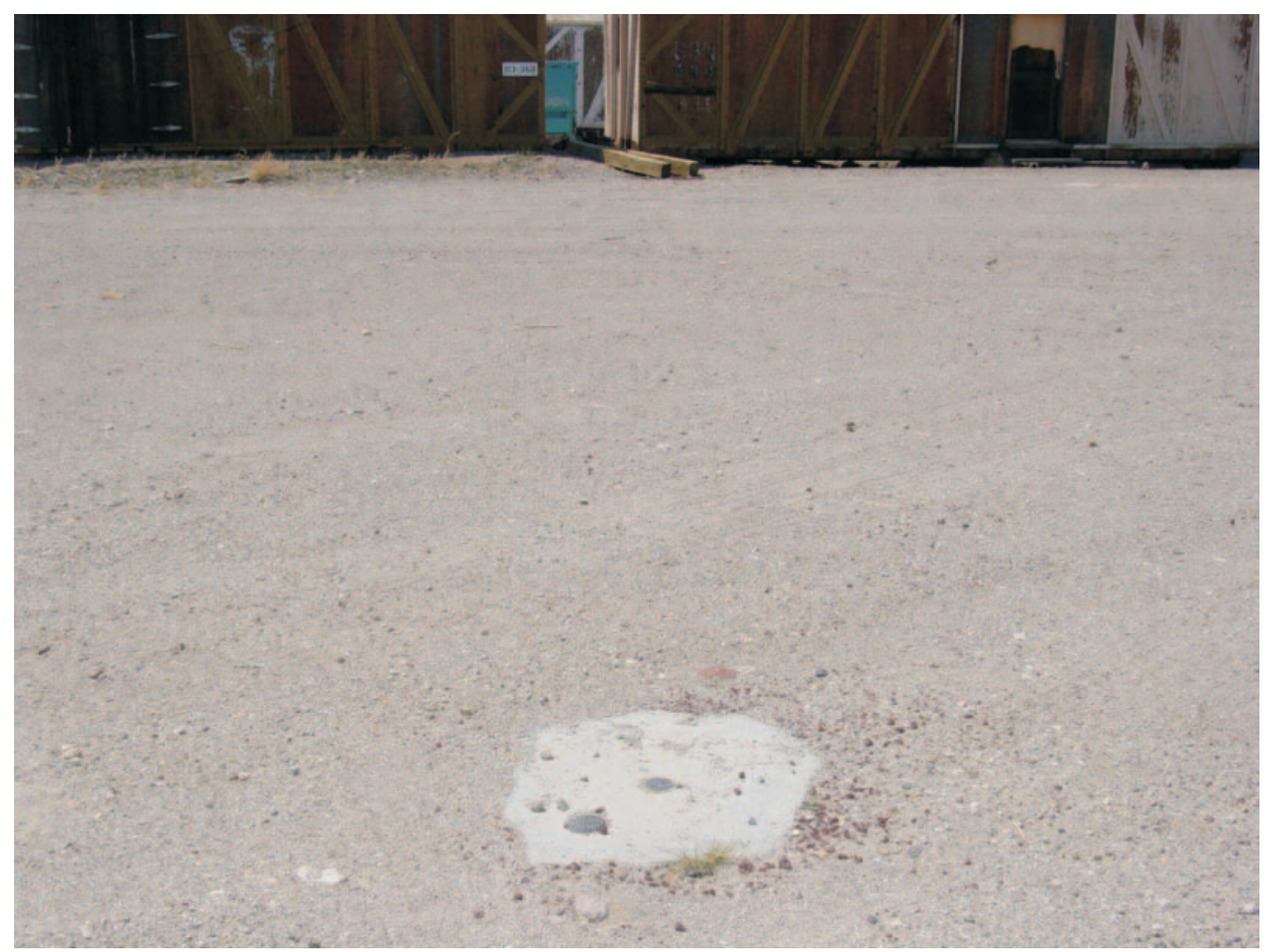

Photograph 31: CAU 424, Landfill Cell A3-8, looking west, 05/09/2006

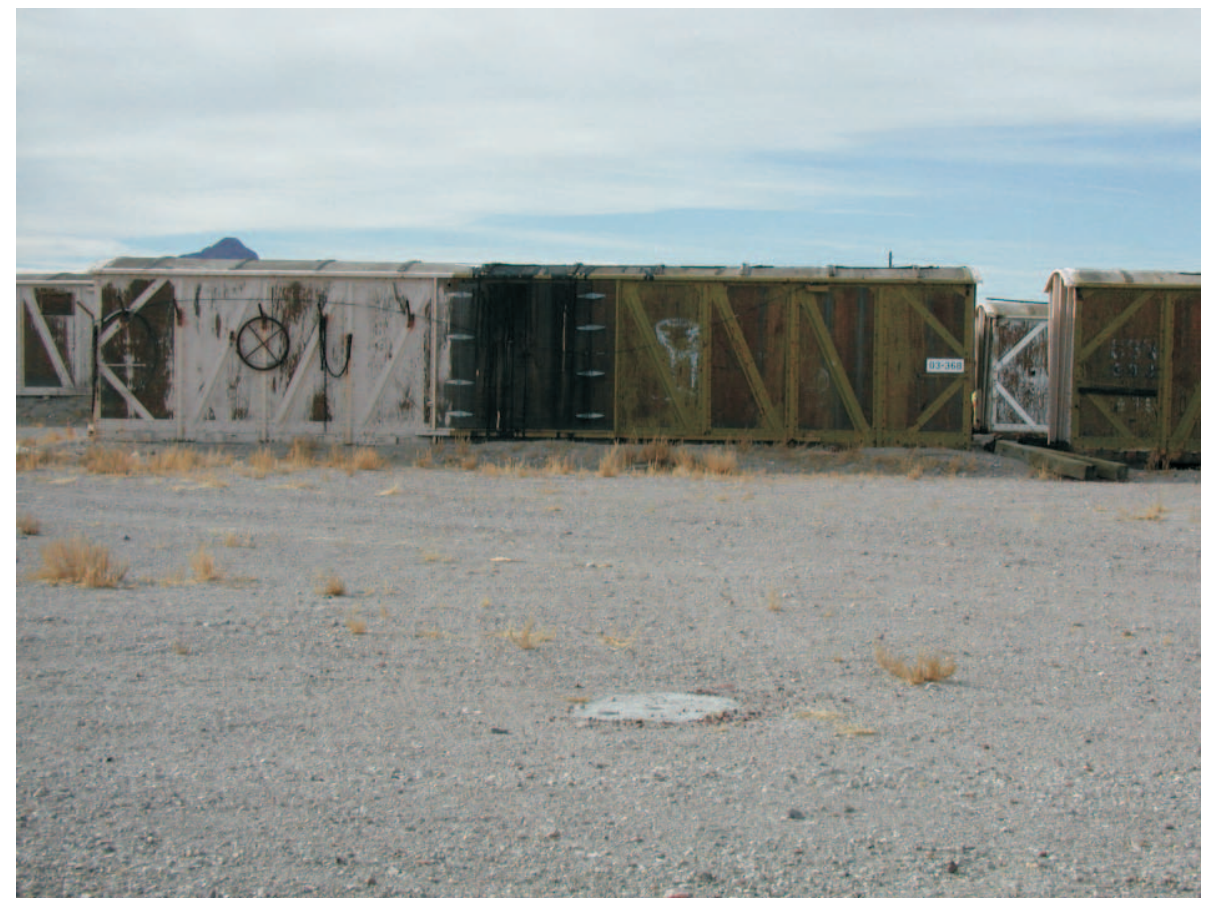

Photograph 32: CAU 424, Landfill Cell A3-8, looking west, 11/15/2006 


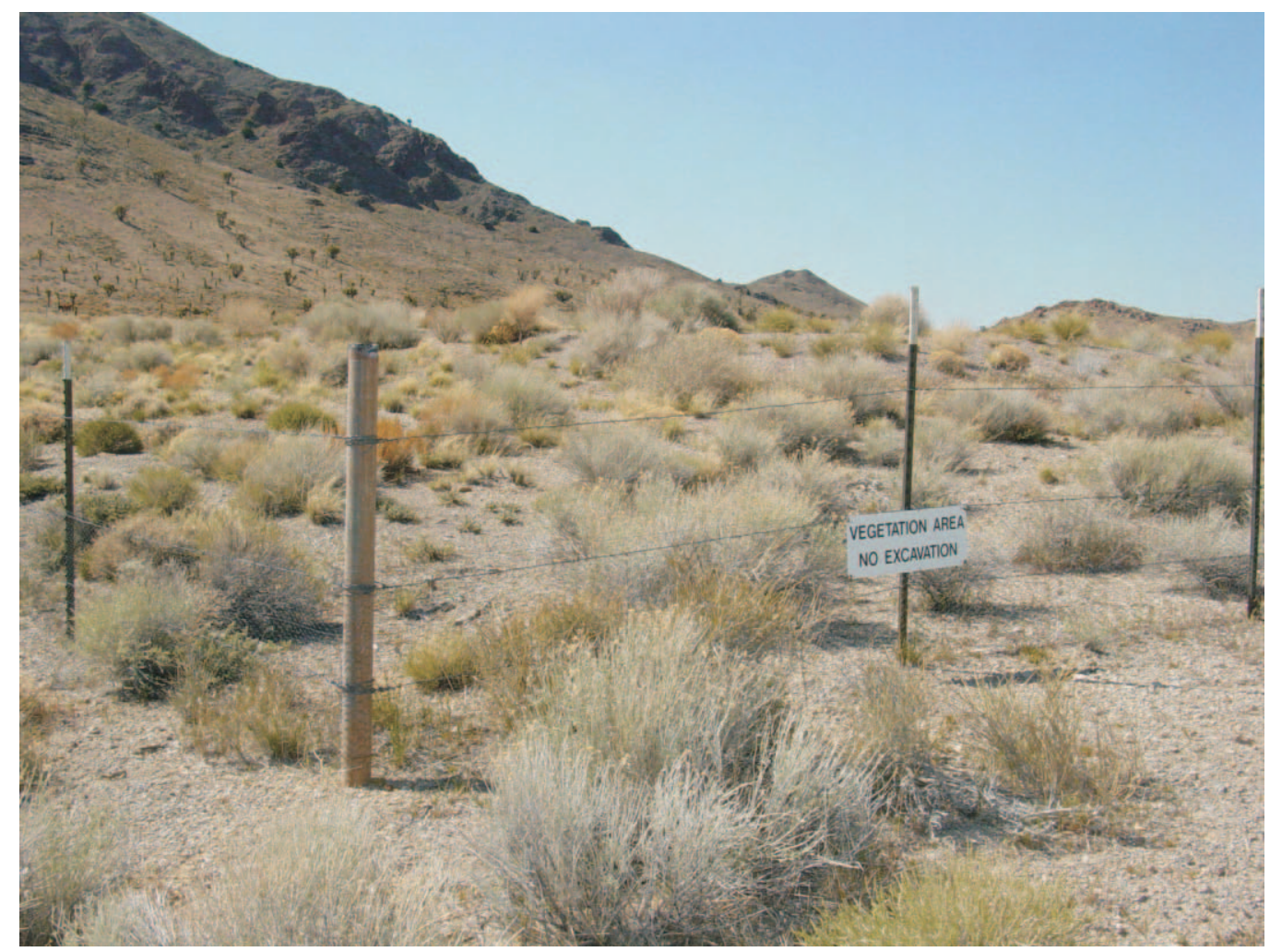

Photograph 33: CAU 426, looking north, 05/09/2006

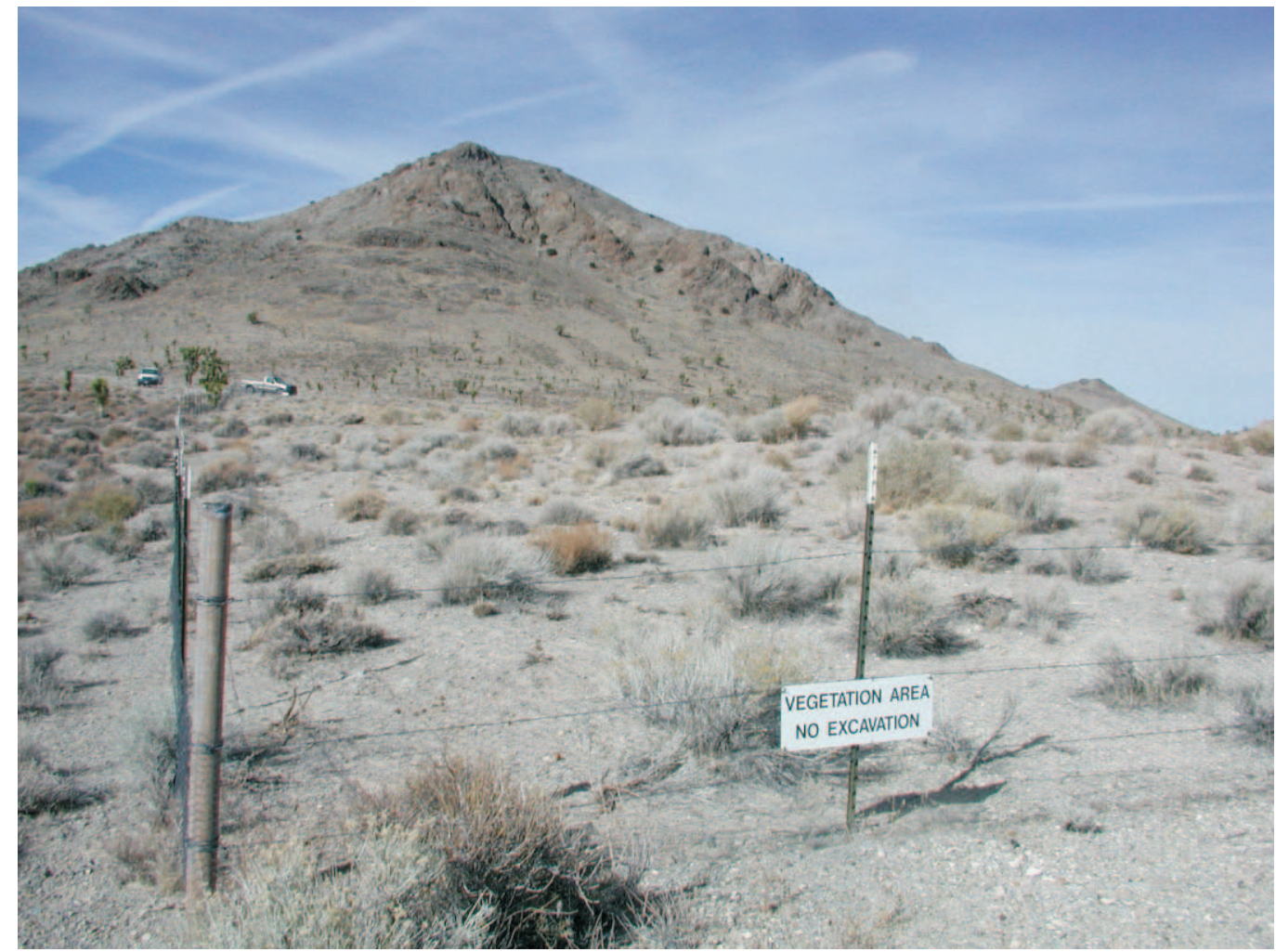

Photograph 34: CAU 426, looking north, 11/15/2006 


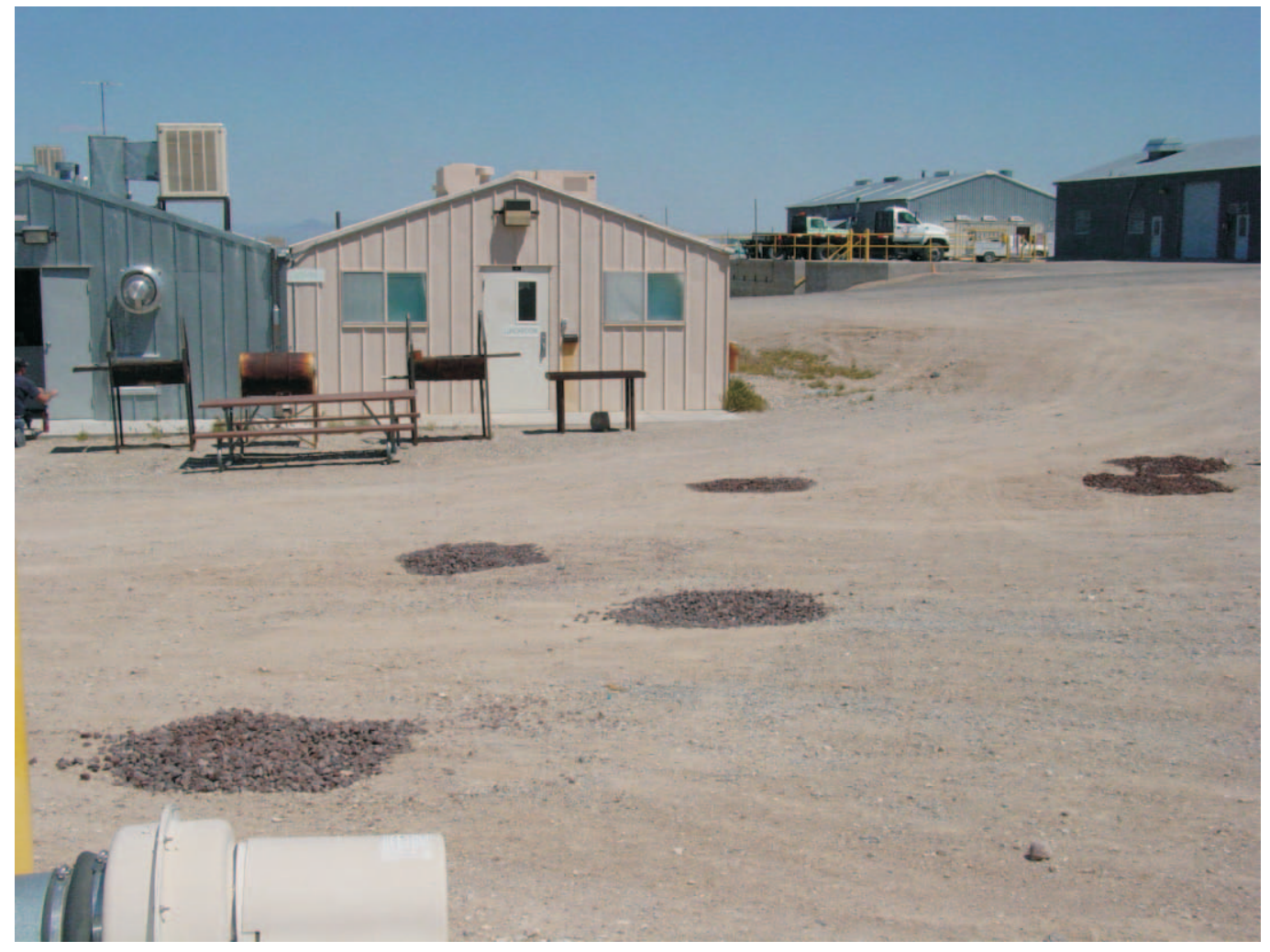

Photograph 35: CAU 427, looking north, 05/09/2006

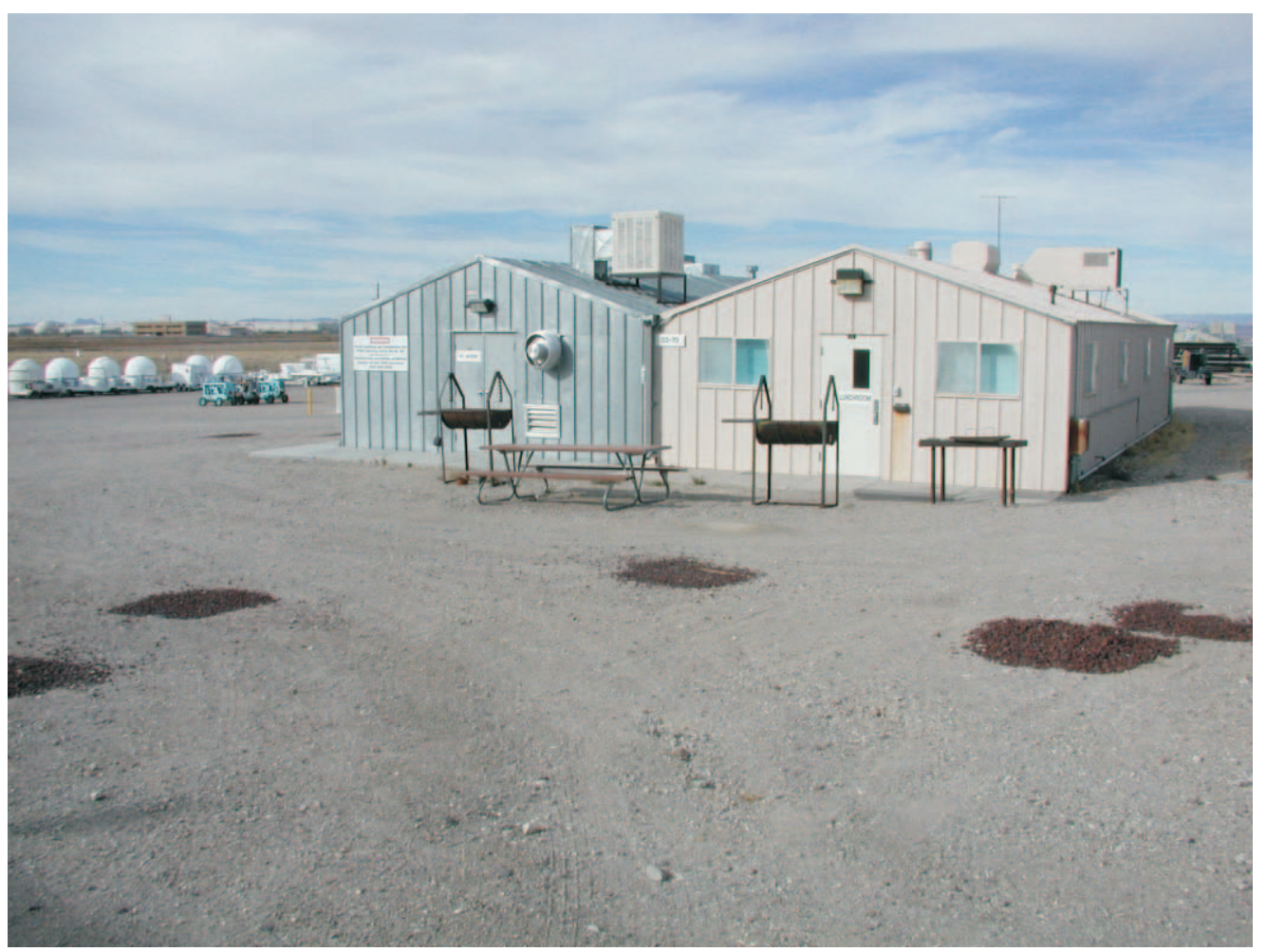

Photograph 36: CAU 427, looking northwest, 11/15/2006 


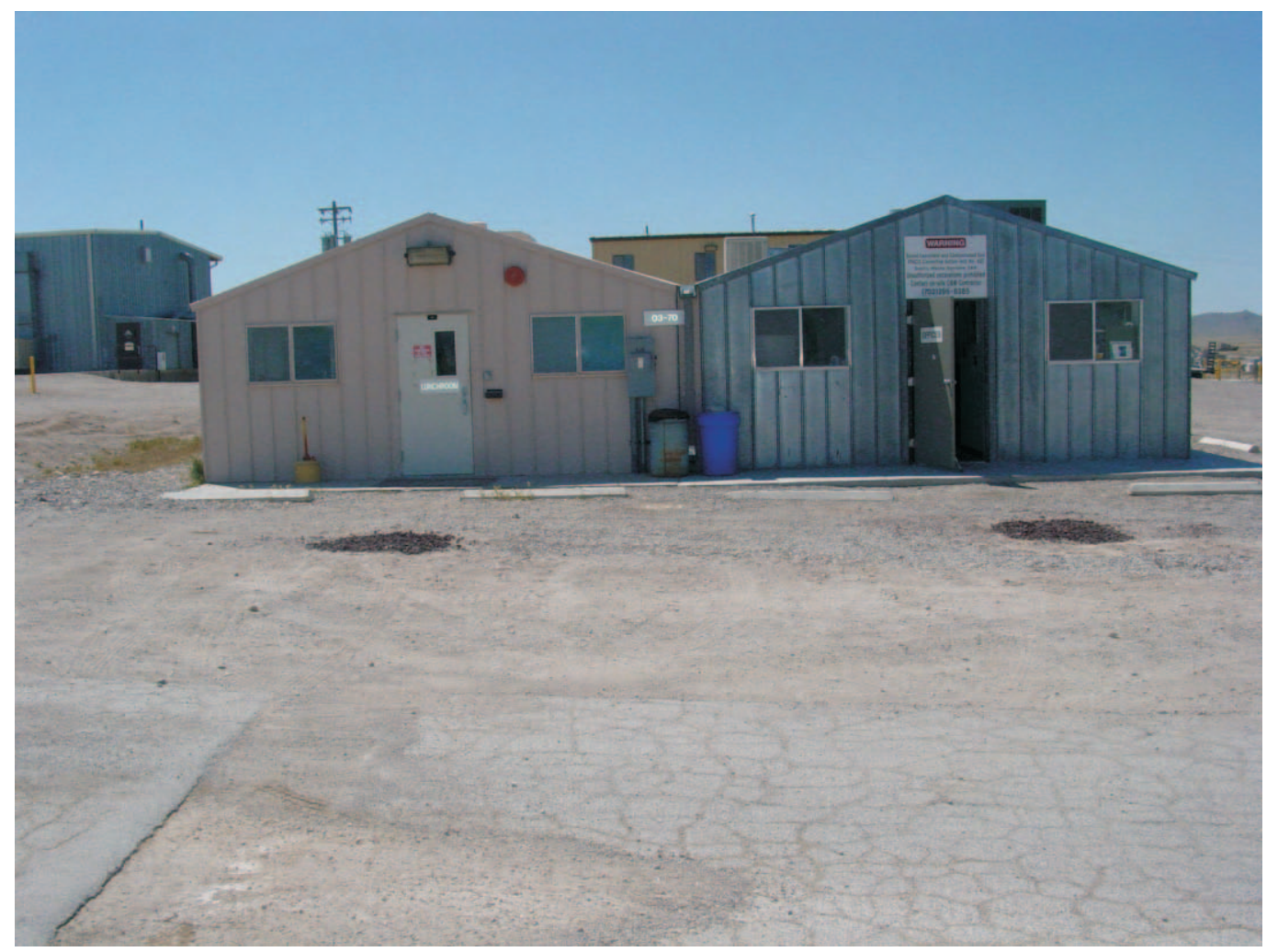

Photograph 37: CAU 427, looking south, 05/09/2006

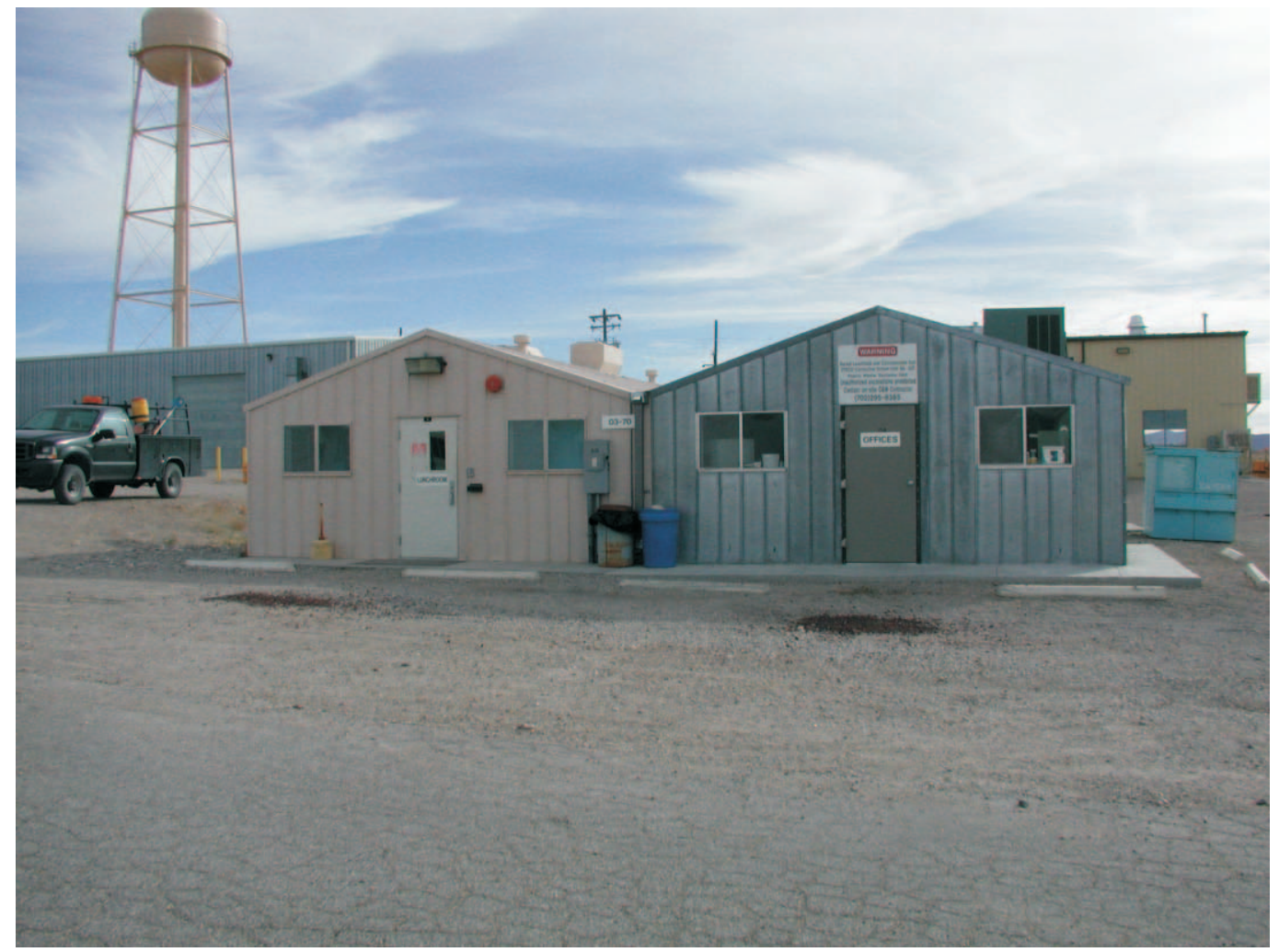

Photograph 38: CAU 427, looking south, 11/15/2006 


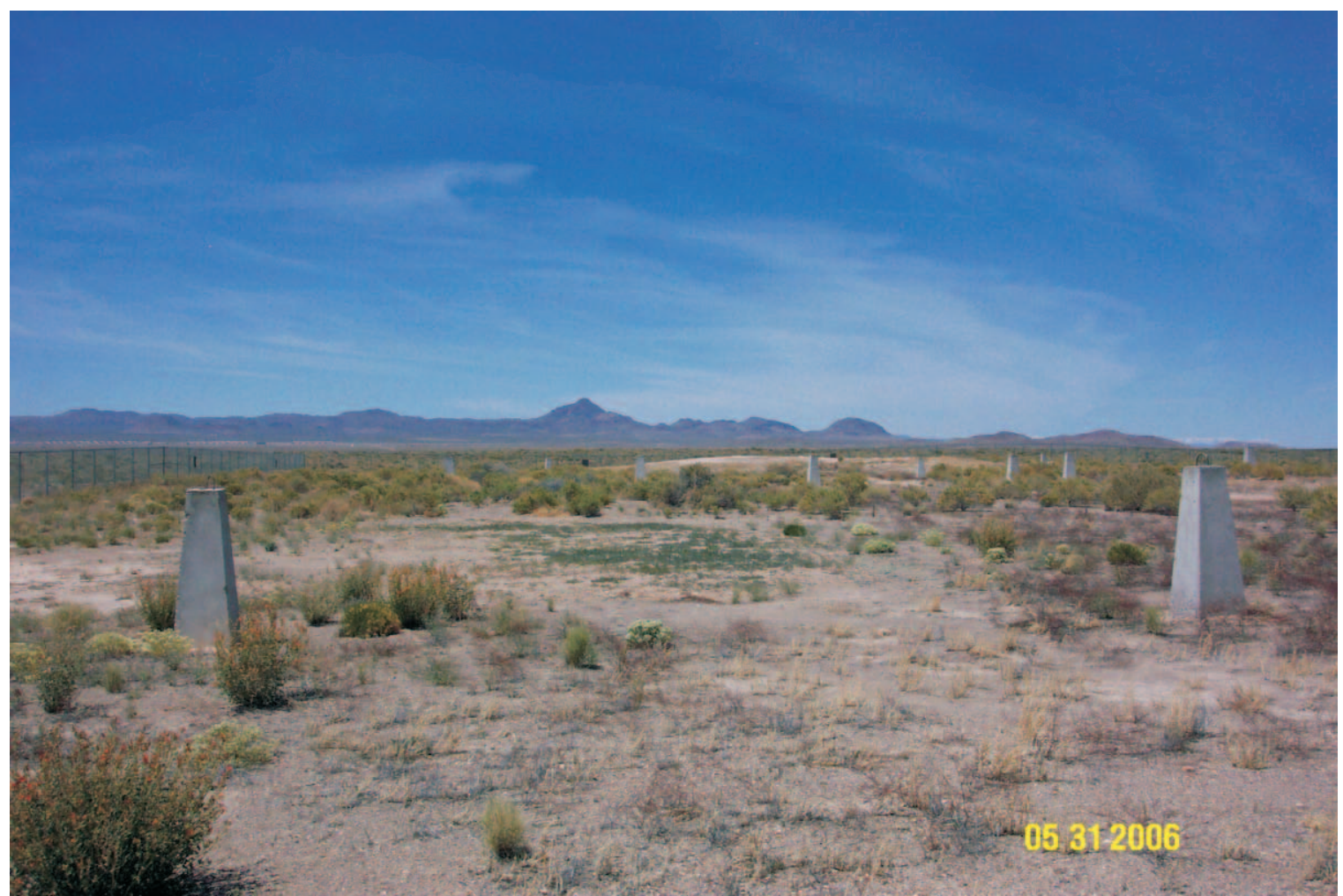

Photograph 39: CAU 453, looking west, 05/31/2006

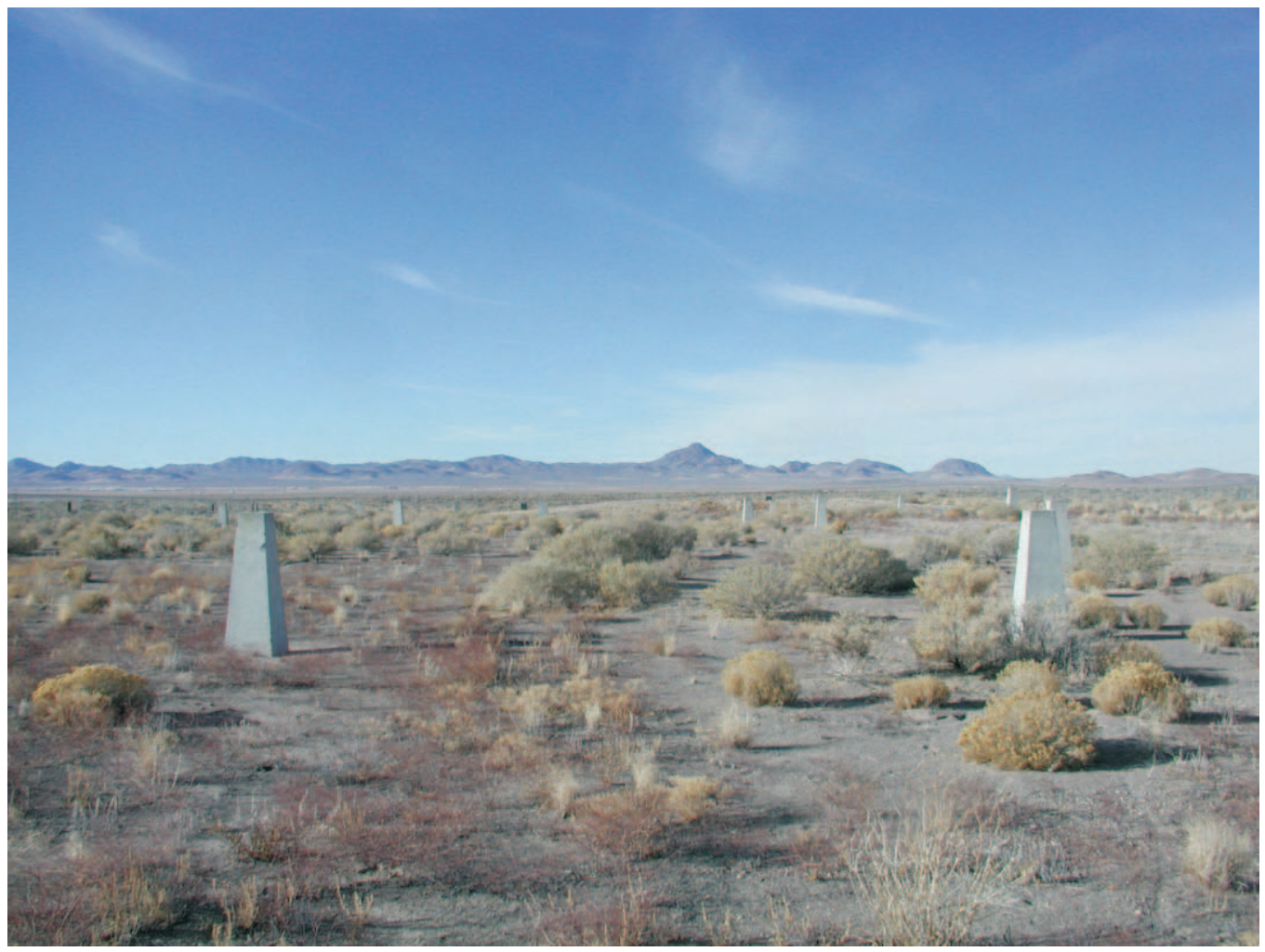

Photograph 40: CAU 453, looking west, 11/15/2006 


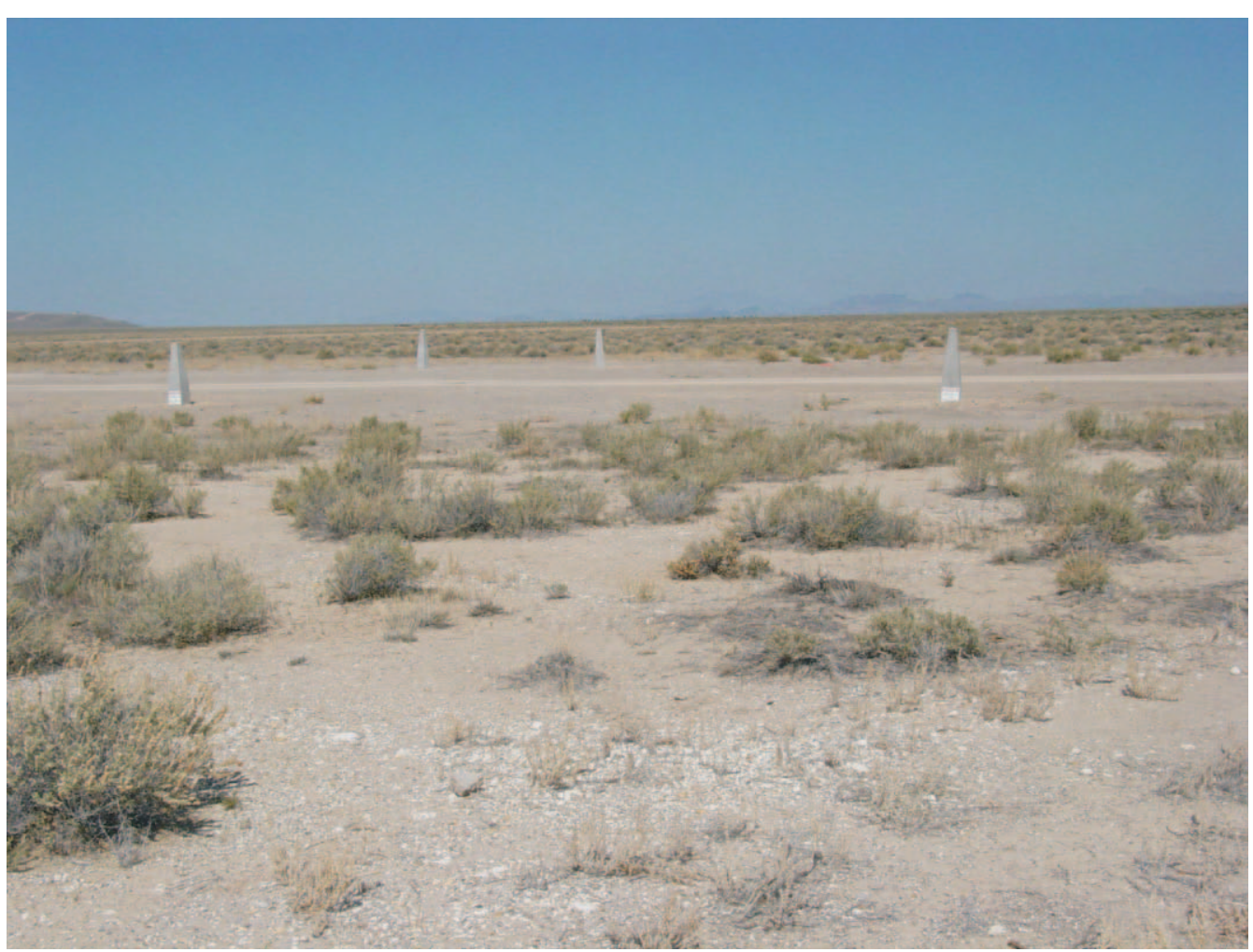

Photograph 41: CAU 487, A-8 anomaly, looking west 05/09/2006

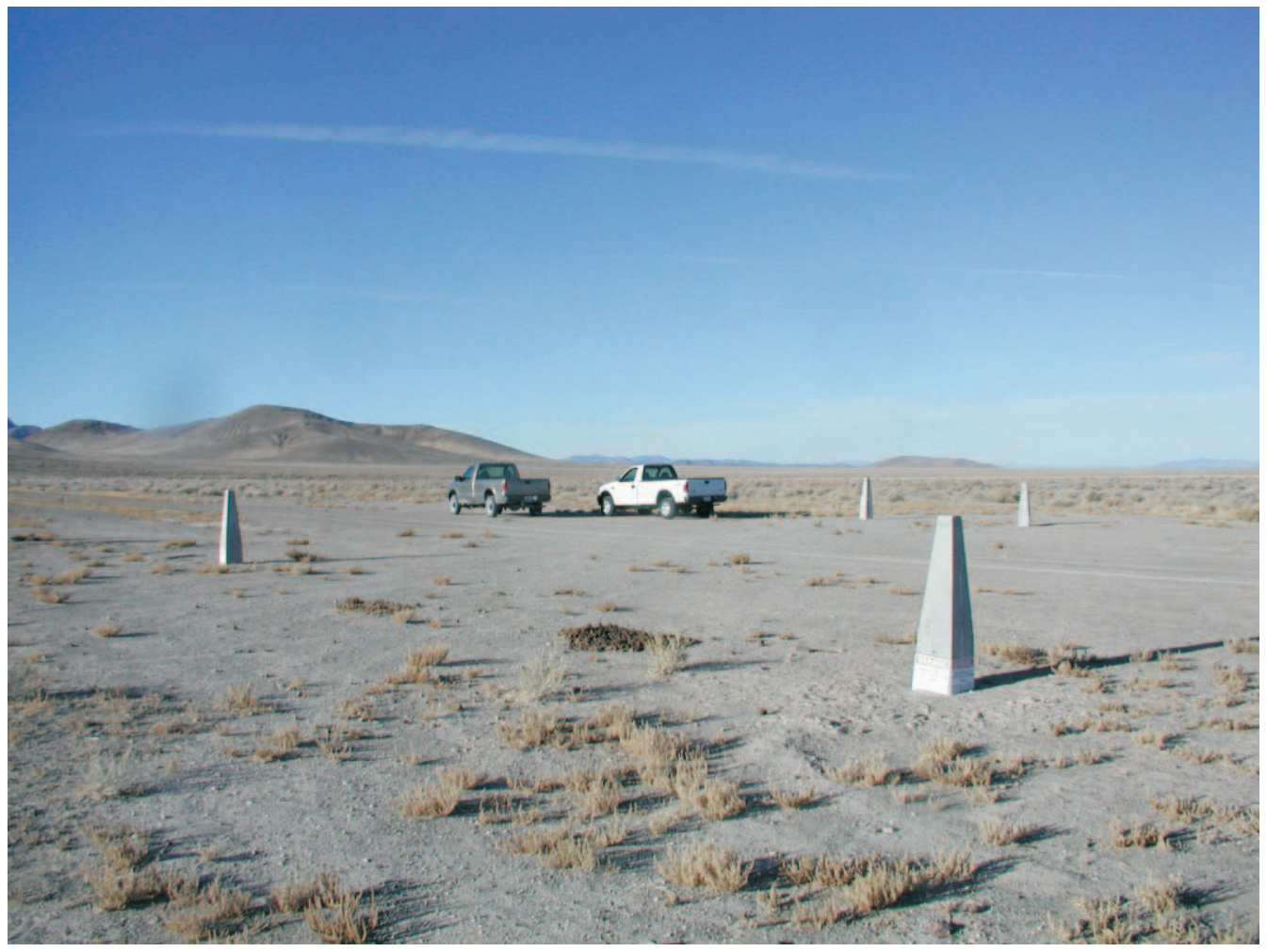

Photograph 42: CAU 487, A-8 anomaly, looking southwest 11/15/2006 


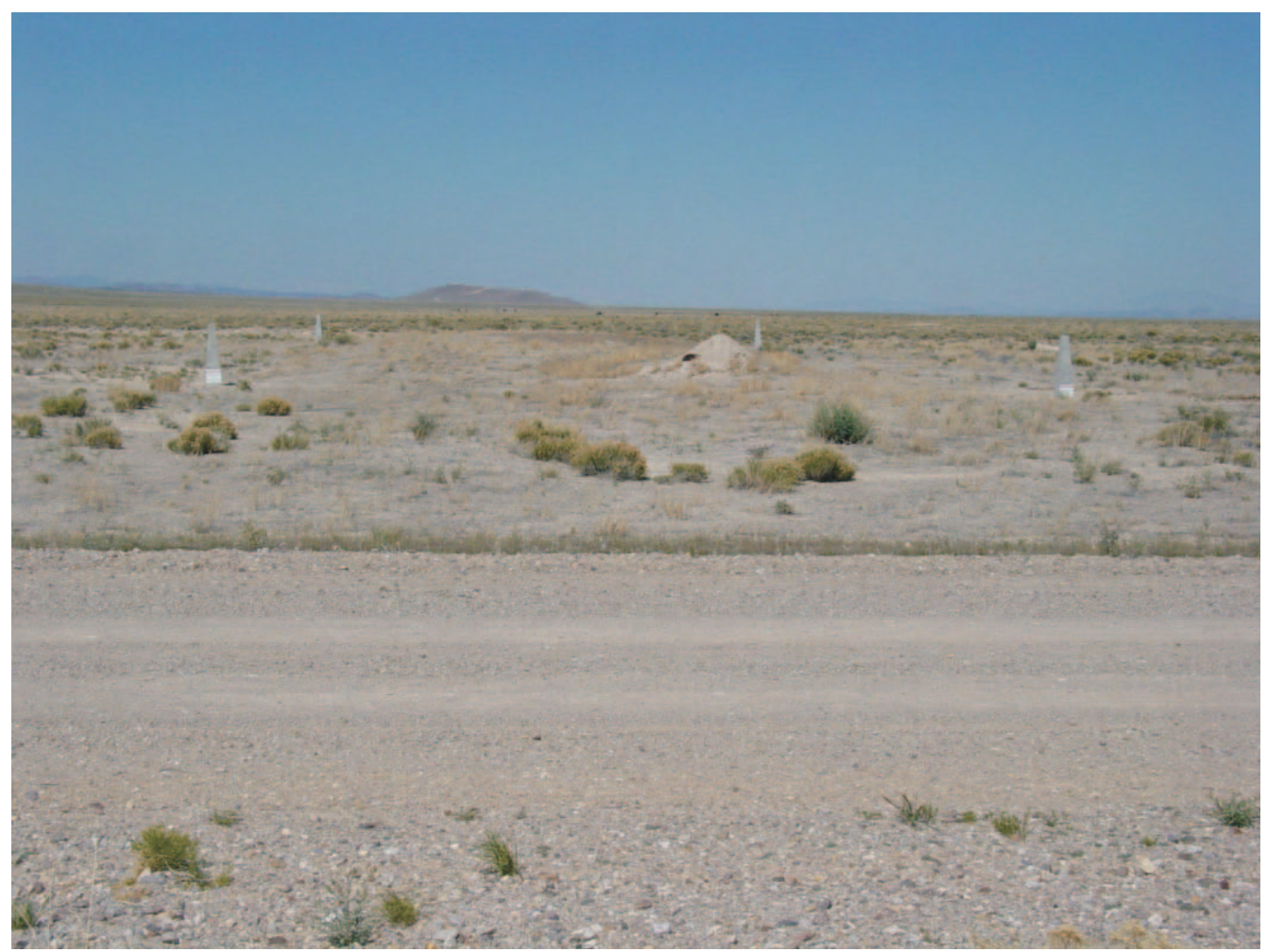

Photograph 43: CAU 487, A-17 anomaly, looking west 05/09/2006

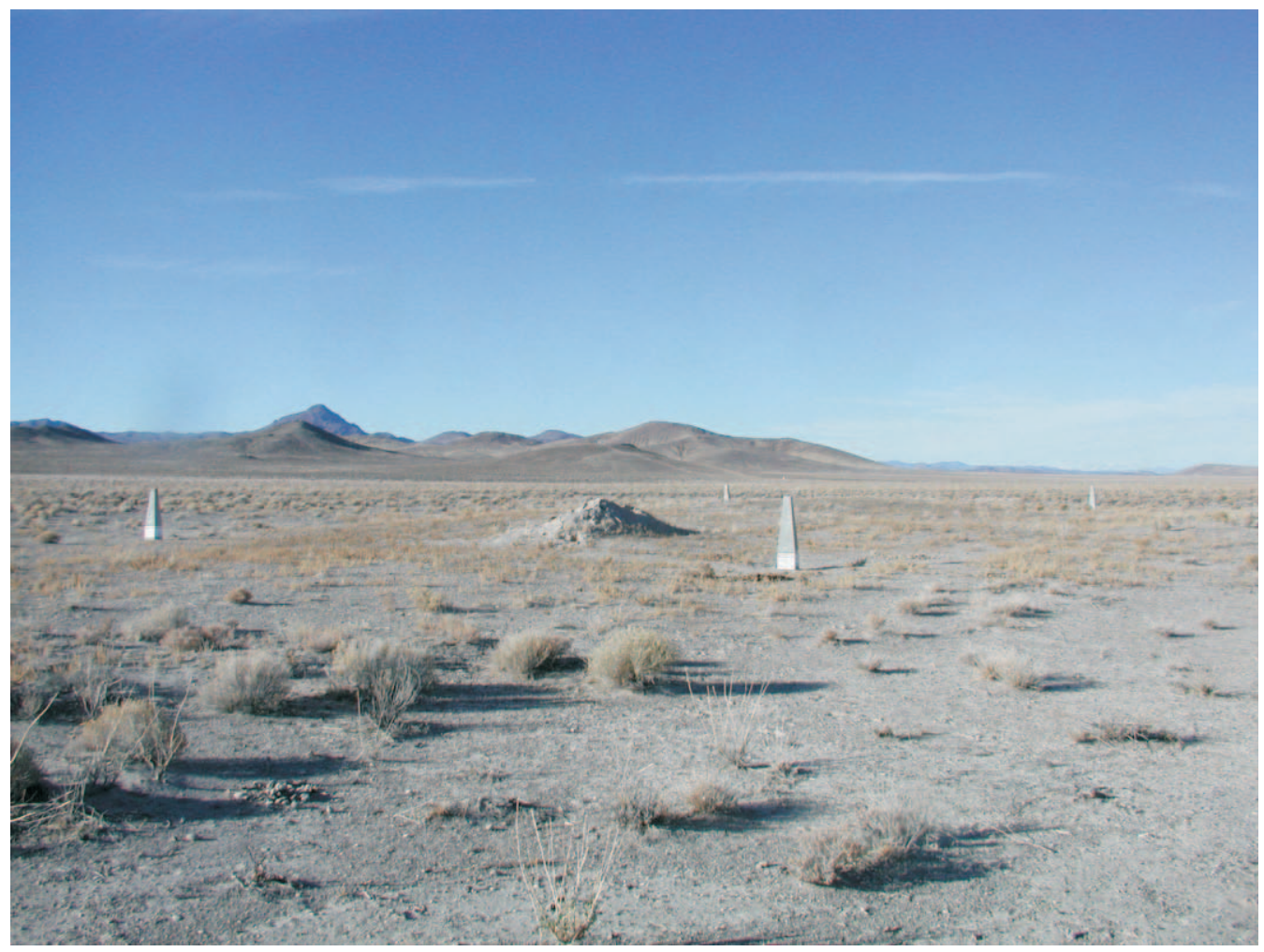

Photograph 44: CAU 487, A-17 anomaly, looking southwest, 11/16/2005 
Post-Closure Inspection Report - TTR

Revision: 0

Date: June 2007

\section{ATTACHMENT F \\ Post-Closure Vegetation \\ MONITORING REPORT}


Post-Closure Inspection Report - TTR

Revision: 0

Date: June 2007

\section{THIS PAGE INTENTIONALLY LEFT BLANK}

F-2 


\title{
Post-Closure Vegetation Monitoring Report FOR CORRECTIVE ACTION UNITS:
}

\author{
400, Five Points LANDFiLl (TTR)
}

400, Bomblet Pit (TTR)

\section{4, ROLLER COASTER LAGOONS AND TRENCH (TTR)}

407, Roller CoAster RadSAFe Area (TTR)

426, CaCtus SPRing WASTE TRENCHES (TTR)

Field Work Completed on

$$
\text { June } 13 \text { - 14, } 2006
$$

Report Prepared

by

Dave Anderson

Ecological Services

September 2006 
Post-Closure Inspection Report - TTR

Revision: 0

Date: June 2007

THIS PAGE INTENTIONALLY LEFT BLANK 


\section{TABLE OF CONTENTS}

1.0 INTRODUCTION F-7

2.0 OBJECTIVES .F-7

3.0 METHODS F-7

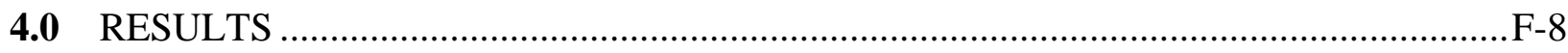

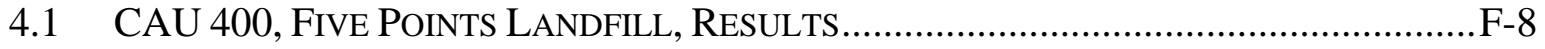

4.1.1 Plant Cover ......................................................................................

4.1.2 Plant Density ............................................................................

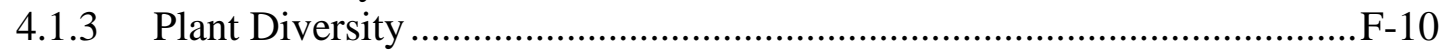

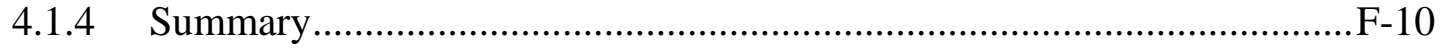

4.2 CAU 400, Bomblet Pit, Results....................................................................

4.2.1 Plant Cover ............................................................................F-12

4.2.2 Plant Density ...........................................................................F-12

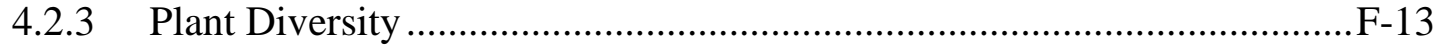

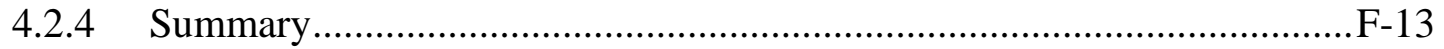

4.3 CAU 404, Staging AREa, Results .................................................................

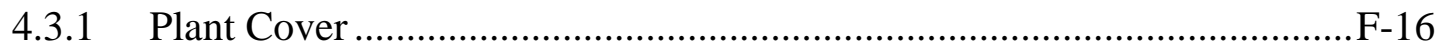

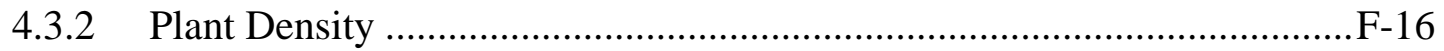

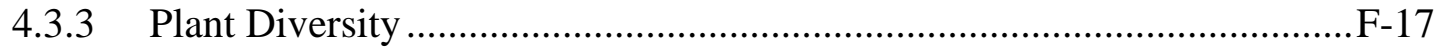

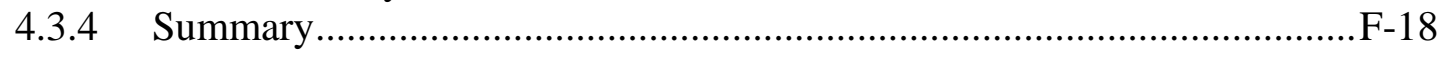

4.4 CAU 404, Cover, Results .......................................................................

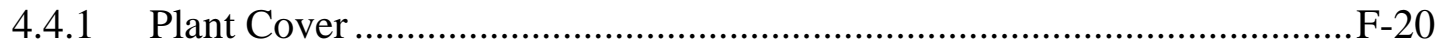

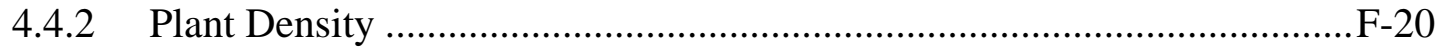

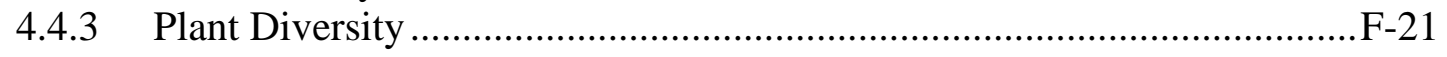

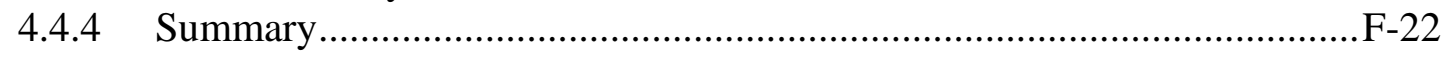

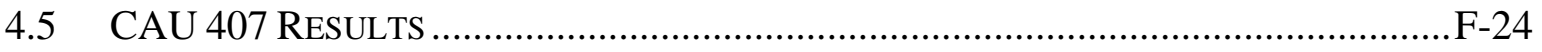

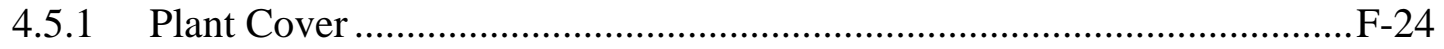

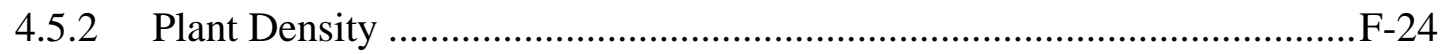

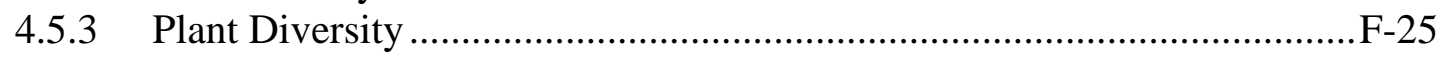

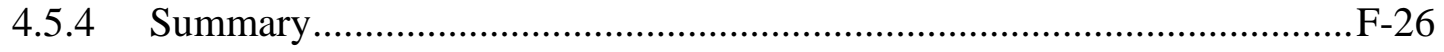

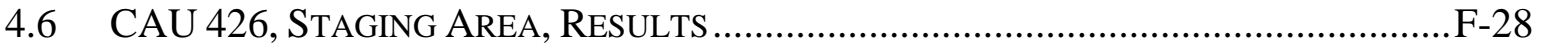

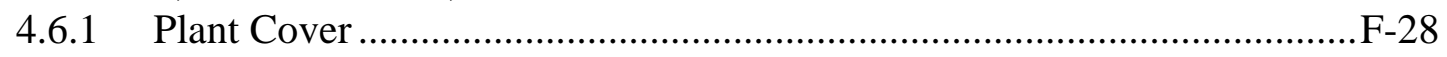

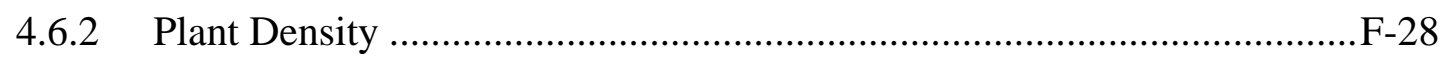

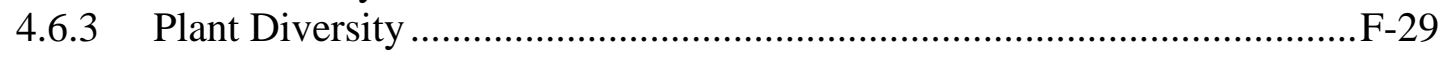

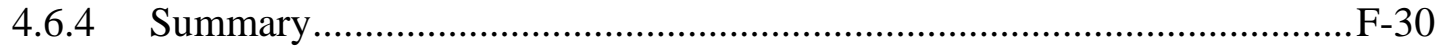

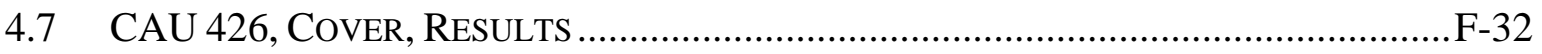

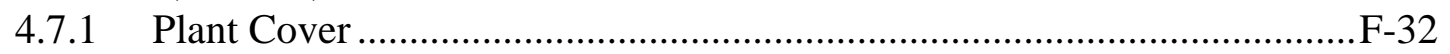

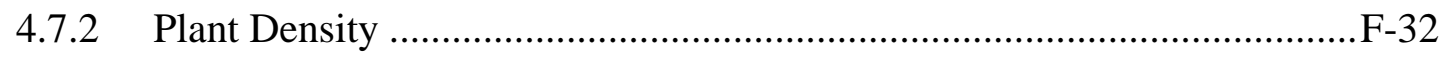

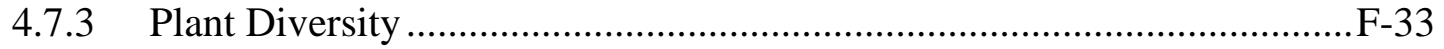

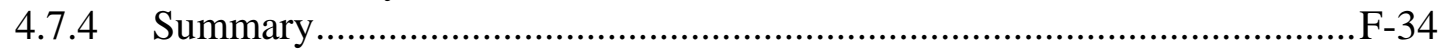




\section{LIST OF TABLES}

TABle 1. Plant Cover (\%) On CAU 400, Five Points LANDFiLl ...........................................8

TABle 2. Plant Density (Plants PER $\mathrm{M}^{2}$ ) ON CAU 400, Five Points LANDFill ......................F-9

Table 3. Diversity of Perennial Plant Species on CAU 400, Five Points Landfill.......F-10

Table 4. Plant Cover (\%) on CAU 400, Bomblet Pit .....................................................F-12

TABle 5. Plant Density (Plants PER M²) on CAU 400, Bomblet Pit ................................F-13

Table 6. Diversity of Perennial Plant Species on CAU 400, Bomblet Pit.....................F-13

Table 7. Plant Cover (\%) on CAU 404, Staging Area ...................................................F-16

TABle 8. Plant DENSITY (PlantS PER M²) ON CAU 404, StAGING AREA ..............................F-17

Table 9. Diversity of Perennial Plant Species on CAU 404, Staging Area ..................F-17

TABle 10. Plant Cover (\%) ON CAU 404, Cover .............................................................F-20

TABle 11. Plant Density (PLANTS PER M²) ON CAU 404, COVER .........................................F-21

Table 12. Diversity of Perennial Plant Species on CAU 404, Cover.............................F-21

TABle 13. Plant Cover (\%) ON CAU 407......................................................................F-24

TABLE 14. PLANT DENSITY (PLANTS PER M ${ }^{2}$ ) ON CAU 407 ........................................................25

TABle 15. Diversity Of PERENNIAL Plant SPECIES ON CAU 407 .......................................F-26

Table 16. Plant Cover (\%) on CAU 426, Staging Area ................................................F-28

TABle 17. Plant Density (Plants PER M²) on CAU 426, StAGing Area ............................F-29

Table 18. Diversity of Perennial Plant Species on CAU 426, Staging Area ................F-29

TABle 19. Plant Cover (\%) ON CAU 426, Cover ..................................................................32

TABle 20. Plant Density (PlantS PER M²) ON CAU 426, COVER ............................................33

Table 21. Diversity of Perennial Plant Species on CAU 426, Cover ............................F-33 


\subsection{INTRODUCTION}

In the fall of 1997, Corrective Action Units (CAUs) 400 (Bomblet Pit and Five Points Landfill), 404 (Roller Coaster Lagoons and Trench), and 426 (Cactus Spring Waste Trenches) were seeded with a mix of seeds of native shrubs and grasses. Each site was mulched with straw, and the straw was crimped into the soil. The sites have been protected from grazing animals (e.g., horses and rabbits) since that time with a 4-foot high perimeter barbed wire fence with 2-foot high chicken wire along the base of the fence. In the fall of 2000, the cover at CAU 407 (Roller Coaster RadSafe Area) was revegetated using similar revegetation techniques.

Remedial revegetation has occurred at two of the sites. A flash flood swept through the center of the CAU 400 Five Points Landfill site in the summer of 2003. The perimeter fence was damaged, and much of the vegetation through the center of the site was lost. The fence was repaired, and the site was reseeded in the fall of 2004. After CAU 407 was revegetated in 2000, cover repairs resulted in the loss of the vegetation that had become established. In the fall of 2004, erosion channels on the cover were repaired, and the site was reseeded. An erosion blanket was used to minimize erosion.

Each site has been monitored periodically since revegetation occurred to document the success of reclamation efforts and identify any problems. The first year of monitoring was designed to determine if germination of seeded plant species had occurred and included plant density estimates and photographic documentation. Monitoring in subsequent years evaluated plant establishment and long-term vegetation survival, and compared plant cover and density with adjacent reference areas (undisturbed sites).

\subsection{OBJECTIVES}

This report documents the methodology and results of monitoring conducted in June 2006 at CAU 400, CAU 404, CAU 407, and CAU 426, which are located on the Tonopah Test Range in central Nevada. The status of the vegetation is described and compared with adjacent undisturbed areas. Concerns and issues are identified, and remedial actions are recommended to ensure that a viable vegetative cover is maintained at each site.

\subsection{METHODS}

Ecological Services staff scientists inspected the sites on June 13 and 14, 2006. Plant cover and density estimates were made, wildlife usage was noted, and soil erosion conditions were evaluated. Plant cover was estimated using an optical point projection device or cover scope. Cover sample points were taken at given intervals along a permanently placed linear transect. Plant density was estimated using one meter square quadrats, which are located at given intervals along each transect. The total number of individual plants located within the boundaries of each quadrat was recorded. The data were averaged over all quadrats to obtain average plant densities (plants per square meter $\left[\mathrm{m}^{2}\right]$ ). Wildlife usage was determined by noting any wildlife or wildlife sign (i.e., burrows) observed during sampling. The erosion condition of the soil was determined using a modified Bureau of Land Management erosion condition classification (Appendix F-2). Reference areas were similarly sampled, and respective data were used as standards to evaluate revegetation success. 
Revegetation is typically considered successful when a predetermined percentage of the perennial plant cover and density on adjacent, undisturbed plant communities is achieved. A percentage was not established for these sites; however, a typical percentage used to determine reclamation success is 70 percent and is usually achieved, at the earliest, 5 years after revegetation is completed and more typically in the tenth year following revegetation. 2006 is the ninth year since revegetation occurred at CAUs 400, 404, and 426. Undisturbed plant communities (i.e., reference sites) are sampled annually at each site. Revegetation of CAU 407 originally occurred in 2000; however, the site was later disturbed and re-seeded in the fall of 2004. In addition, sections of the CAU 400 Five Points Landfill site were reseeded in the fall of 2004 to repair damage that had occurred from a flash flood.

\subsection{RESULTS}

The results of the 2006 monitoring are reported below. The plant density and cover estimate data collected was summarized and compared to data collected from reference areas. Based on perennial plant density and perennial plant cover, the sites were considered successfully reclaimed if 70 percent of the density and cover on the respective reference areas was attained.

\subsection{CAU 400, Five Points Landfill, Results}

Five transects were sampled in the fenced area at the Five Points Landfill. Plant cover, density, and diversity were averaged over the five transects and are presented in Tables 1, 2, and 3.

\subsubsection{Plant Cover}

Total plant cover decreased in 2006. There was a decrease in shrub cover from 2005 to 2006; however, in 2005, shrub cover was only averaged over two transects located in non-flooded areas. In 2006, cover estimates included the two transects in the non-flooded areas and an additional three transects located on the flooded area that was reseeded in the fall of 2004. Although the amount of shrub cover decreased from 2005 to 2006, grass cover more than doubled. Grass cover was relatively high the first few years after seeding, but due to below normal precipitation in 2003 and 2004 and a flash flood in 2003, grasses have contributed less to overall plant cover since 2004. Forbs fluctuate from year to year depending on precipitation. The amount of forb cover declined from 9 percent in 2005 to 6 percent in 2006. The changes in shrub and grass cover are better indicators of overall vigor and stability of the vegetative community than are changes in forb cover.

Table 1. Plant Cover (\%) on CAU 400, Five Points Landfill

\begin{tabular}{|c|c|c|c|c|c|c|c|c||}
\hline & $\mathbf{2 0 0 0}$ & $\mathbf{2 0 0 2}$ & $\mathbf{2 0 0 3}$ & $\mathbf{2 0 0 4}$ & $\mathbf{2 0 0 5}$ & $\mathbf{2 0 0 6}$ & Reference & Standard \\
\hline \hline Shrubs & 2.5 & 8.3 & 9.2 & 8.1 & 9.0 & 8.5 & 8.3 & 5.8 \\
\hline Grasses & 10.0 & 22.5 & 10.0 & 3.7 & 1.3 & 3.3 & 5.8 & 4.1 \\
\hline Forbs/Annuals & 3.3 & 1.7 & 0.0 & 2.2 & 9.0 & 6.0 & 0.0 & 0.0 \\
\hline Total Plant Cover & $\mathbf{1 5 . 8}$ & $\mathbf{3 2 . 5}$ & $\mathbf{1 9 . 2}$ & $\mathbf{1 4 . 0}$ & $\mathbf{1 9 . 3}$ & $\mathbf{1 7 . 8}$ & $\mathbf{1 4 . 1}$ & $\mathbf{9 . 9}$ \\
\hline
\end{tabular}




\subsubsection{Plant Density}

Fourwing saltbush has been the most dominant shrub since seeding occurred. In 2006, the density of fourwing saltbush decreased, and for the first time winterfat was found. The decrease in the number of shrubs was accompanied by an increase in the density of grasses, mainly on the newly seeded area, where numerous squirreltail and Indian ricegrass were found. Even though the number of grasses doubled from 2005 to 2006, overall grass density is still below that experienced from 2002 to 2004. The density of annual forbs is higher than in years prior to 2005, although it decreased by approximately 75 percent from 2005 to 2006.

Wildlife use of the site has been evident since revegetation was completed. Small mammal burrows are located throughout the site and are most abundant in the southeastern section of the site, out of the path of flooding.

There was no evidence of erosion until the low-lying areas were flooded in 2003. Standing water was present for several months, resulting in the loss of all vegetation. After the flooded area was reseeded in 2004, there has again been some standing water in the low-lying areas, but the check dams upstream are in place and there were no signs of flooding. There is a small layer of silts/sands in the bottom areas, suggesting some overland erosion, but no erosion gullies were observed, and there does not appear to be any damage to the vegetation.

TAble 2. Plant Density (Plants Per M $^{2}$ ) on CAU 400, Five Points LANDFill

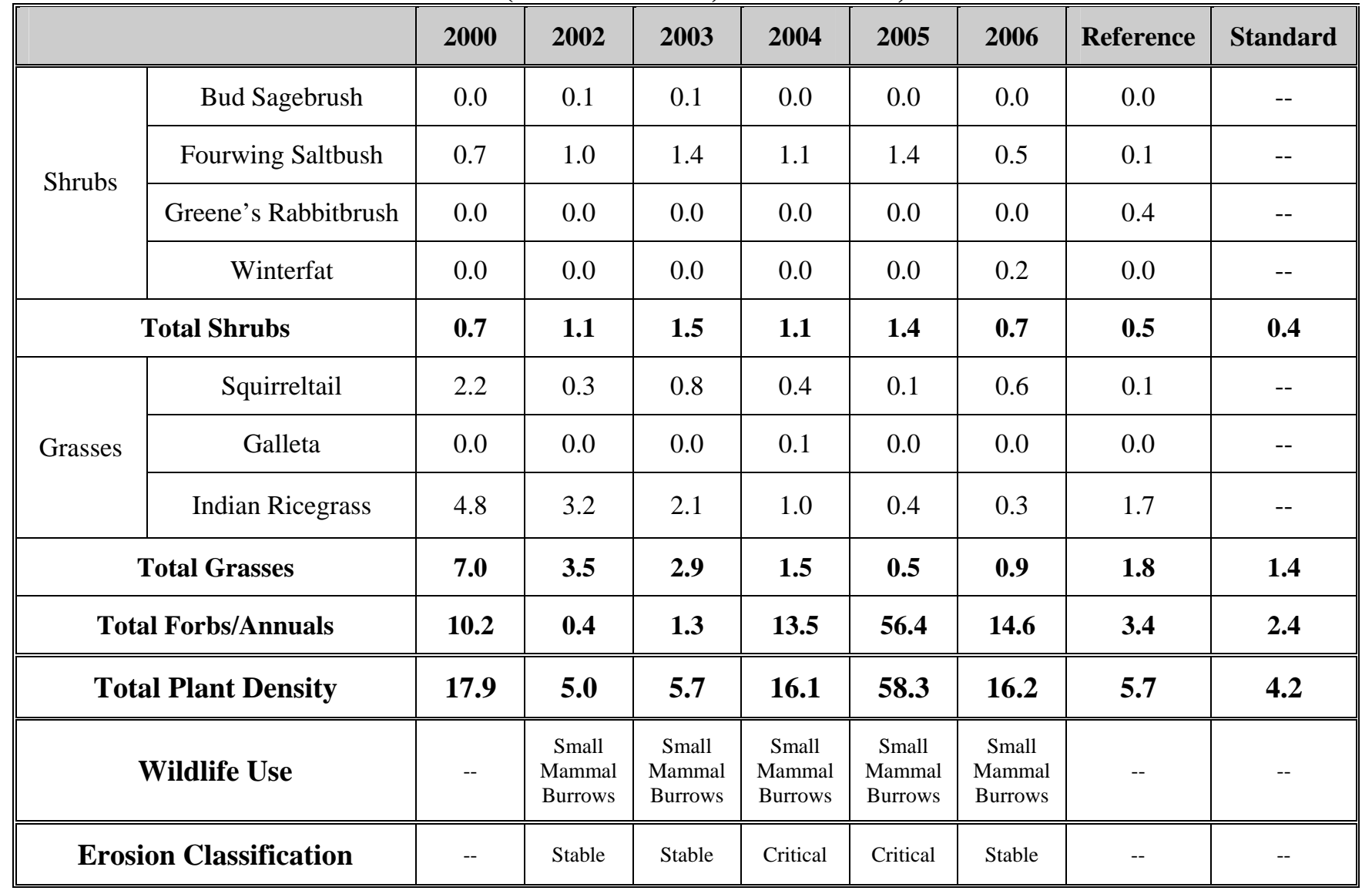

Note: Scientific names of plants are listed in Appendix F-1.

Note: Erosion Classification Chart included in Appendix F-2. 


\subsubsection{Plant Diversity}

Diversity, which is a measurement of the number of different plant species, is used as a measure of plant community vigor. The number of perennial plant species increased to 1.9 species in 2006, from 1.2 species in 2004 and 2005, and close to the overall high of 2.2 species in 2000. The number of shrub and grass species increased, with the number of grasses doubling yet less than the high of 1.8 species in 2000. Shrub diversity in 2006 was the highest ever estimated on the site. Both shrub and grass diversity is higher on the revegetated area than on the reference area.

Table 3. Diversity of Perennial Plant Species on CAU 400, Five Points Landfill

\begin{tabular}{|c|c|c|c|c|c|c|c||}
\hline \hline & $\mathbf{2 0 0 0}$ & $\mathbf{2 0 0 2}$ & $\mathbf{2 0 0 3}$ & $\mathbf{2 0 0 4}$ & $\mathbf{2 0 0 5}$ & $\mathbf{2 0 0 6}$ & Reference \\
\hline \hline Shrubs & 0.4 & 0.5 & 0.6 & 0.6 & 0.7 & 0.9 & 0.5 \\
\hline Grasses & 1.8 & 1.2 & 1.4 & 0.6 & 0.5 & 1.0 & 0.9 \\
\hline $\begin{array}{c}\text { Number of Perennial } \\
\text { Species per Square Meter }\end{array}$ & 2.2 & 1.7 & 2.0 & 1.2 & 1.2 & 1.9 & 1.4 \\
\hline
\end{tabular}

\subsubsection{Summary}

Shrub and grass cover at the Five Points Landfill site increased from 10.3 percent in 2005 to 11.8 percent in 2006. The total shrub and grass cover in 2006 exceeds the success standard of 9.9 percent; however, when considering shrub cover and grass cover separately, only shrub cover exceeds the standard. The 3.3 percent grass cover is below the amount of grass cover in 2002 and 2003 as well as below the success standard of 4.1 percent.

Perennial plants found in the low-lying areas that were flooded and reseeded in 2004 have only experienced two growing seasons and are not as well established as the shrubs and grasses in the non-flooded areas. It would benefit these newly established plants to keep the perimeter fence, at least until revegetation success standards are met for 2 to 3 consecutive years. 


\section{CAU 400, Five Points LANDFiLl, Photographic Reference}

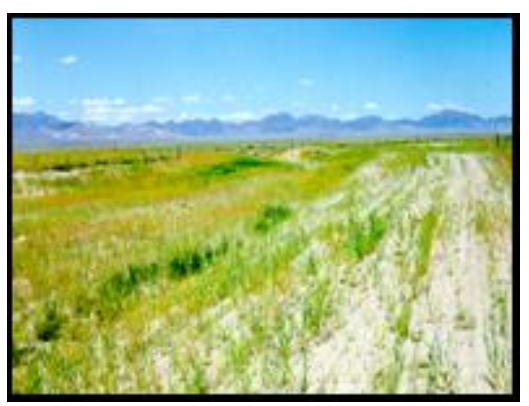

JUNE 1998

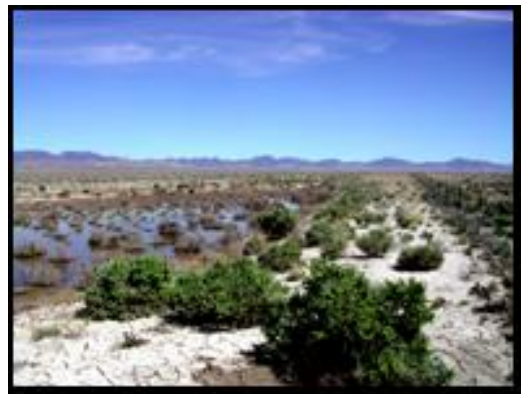

SEPTEMBER 2003

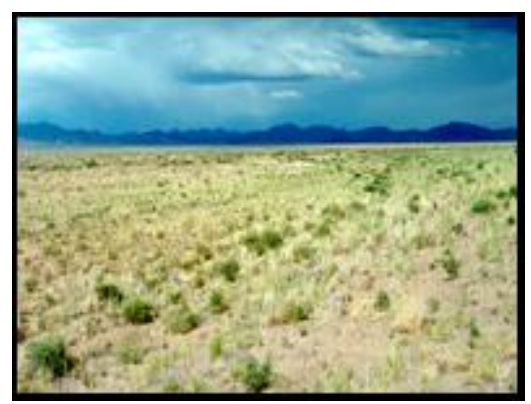

JUNE 2000

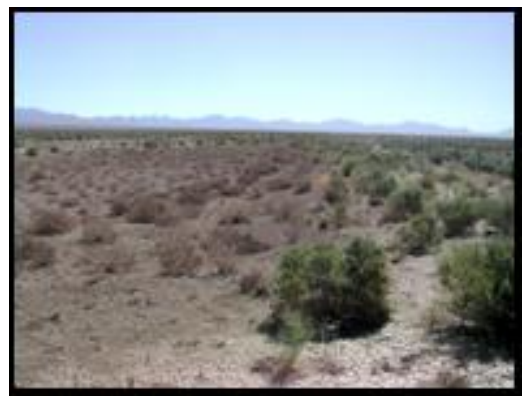

JUNE 2004

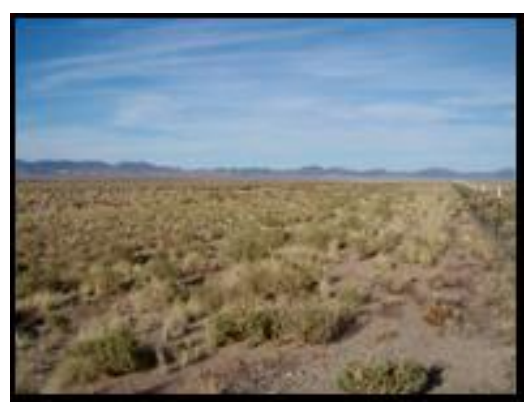

JUNE 2002

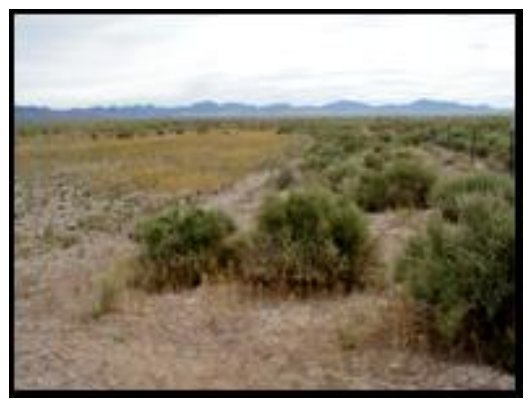

JUNE 2005

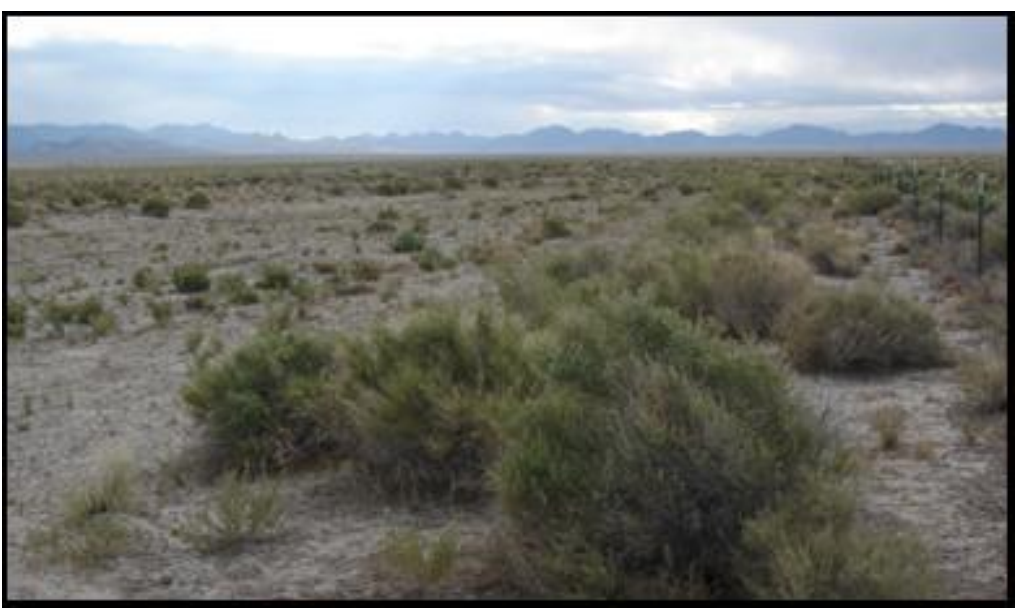

JUNE 2006 


\subsection{CAU 400, Bomblet Pit, Results}

\subsubsection{Plant Cover}

The first few years after revegetation at the Bomblet Pit site, plant cover ranged from 16 to 19 percent and was always higher than on the adjacent undisturbed reference area. In 2003, cover decreased to 10 percent and continued to decrease below 10 percent for the next 2 years. These declines in plant cover were during a period of below average rainfall. The composition of the cover also changed. The first few years consisted of a mix of shrubs and grasses. But the grasses were unable to survive the drought years and have not reestablished on the site since then. Shrubs make up the total 17.5 percent of plant cover recorded in 2006, which is the highest it has been since 2002. There were a number of annual forbs found on the site in 2005, comprising approximately 3.8 percent of the total cover. Forbs were not encountered in 2006.

Table 4. Plant Cover (\%) on CAU 400, Bomblet Pit

\begin{tabular}{|c|c|c|c|c|c|c|c|c||}
\hline & $\mathbf{2 0 0 0}$ & $\mathbf{2 0 0 2}$ & $\mathbf{2 0 0 3}$ & $\mathbf{2 0 0 4}$ & $\mathbf{2 0 0 5}$ & $\mathbf{2 0 0 6}$ & Reference & Standard \\
\hline \hline Shrubs & 15.8 & 18.8 & 10.0 & 7.5 & 8.8 & 17.5 & 10.0 & 7.0 \\
\hline Grasses & 2.6 & 0.0 & 0.0 & 0.0 & 0.0 & 0.0 & 1.3 & 0.9 \\
\hline Forbs/Annuals & 0.0 & 0.0 & 0.0 & 0.0 & 3.8 & 0.0 & 0.0 & 0.0 \\
\hline Total Plant Cover & $\mathbf{1 8 . 4}$ & $\mathbf{1 8 . 8}$ & $\mathbf{1 0 . 0}$ & $\mathbf{7 . 5}$ & $\mathbf{1 2 . 6}$ & $\mathbf{1 7 . 5}$ & $\mathbf{1 1 . 3}$ & $\mathbf{7 . 9}$ \\
\hline Bare Ground & 63.2 & 61.3 & 73.8 & 78.8 & 72.5 & 62.5 & 58.8 & -- \\
\hline Litter & 18.4 & 20.0 & 16.3 & 13.8 & 15.0 & 20.0 & 30.0 & -- \\
\hline
\end{tabular}

\subsubsection{Plant Density}

The density of perennial shrubs and grasses has not changed significantly since 2004. In 2006, there was an increase in the number of shrubs, and for the first time since 2003, Indian ricegrass was found on the site. Shadscale is still the most abundant shrub on the site, but there was an increase in the number of bud sagebrush in 2006. Winterfat, once present at the site, has been absent since 2003. Bud sagebrush, shadscale, and winterfat are the primary shrub species on the reference area. There were no annual forbs encountered in 2006.

The Bomblet Pit site has never shown signs of erosion. Small mammal burrows are present around the periphery of the site. 
TABle 5. Plant Density (Plants PER M $^{2}$ ) ON CAU 400, BoMblet PIT

\begin{tabular}{|c|c|c|c|c|c|c|c|c|c|}
\hline & & 2000 & 2002 & 2003 & 2004 & 2005 & 2006 & Reference & Standard \\
\hline \multirow{4}{*}{ Shrubs } & Bud Sagebrush & 3.8 & 2.5 & 2.6 & 0.8 & 0.9 & 1.7 & 2.4 & -- \\
\hline & Fourwing Saltbush & 0.5 & 0.3 & 0.2 & 0.2 & 0.1 & 0.0 & 0.0 & -- \\
\hline & Greene’s Rabbitbrush & 6.8 & 6.5 & 6.4 & 5.3 & 4.7 & 4.8 & 1.2 & -- \\
\hline & Winterfat & 0.3 & 0.0 & 0.1 & 0.0 & 0.0 & 0.0 & 0.3 & -- \\
\hline \multicolumn{2}{|r|}{ Total Shrubs } & 11.4 & 9.3 & 9.3 & 6.3 & 5.7 & 6.5 & 3.9 & 2.6 \\
\hline \multirow{3}{*}{ Grasses } & Squirreltail & 3.1 & 0.0 & 0.0 & 0.0 & 0.0 & 0.0 & 0.0 & -- \\
\hline & Galleta & 0.0 & 0.0 & 0.0 & 0.0 & 0.0 & 0.0 & 0.0 & -- \\
\hline & Indian Ricegrass & 2.5 & 0.2 & 0.4 & 0.0 & 0.0 & 0.1 & 0.1 & -- \\
\hline \multicolumn{2}{|r|}{ Total Grasses } & 5.6 & 0.2 & 0.4 & 0.0 & $\mathbf{0 . 0}$ & 0.1 & 0.1 & 0.0 \\
\hline \multicolumn{2}{|c|}{ Total Forbs/Annuals } & 5.4 & 0.3 & 0.1 & 1.1 & 56.0 & $\mathbf{0 . 0}$ & 0.5 & 0.3 \\
\hline \multicolumn{2}{|c|}{ Total Plant Density } & 22.4 & 9.8 & 9.8 & 7.4 & 61.7 & 6.6 & 4.5 & 2.9 \\
\hline \multicolumn{2}{|r|}{ Wildlife Use } & $\begin{array}{c}\text { Small } \\
\text { Mammal } \\
\text { Burrows }\end{array}$ & $\begin{array}{c}\text { Small } \\
\text { Mammal } \\
\text { Burrows }\end{array}$ & $\begin{array}{c}\text { Small } \\
\text { Mammal } \\
\text { Burrows }\end{array}$ & $\begin{array}{c}\text { Small } \\
\text { Mammal } \\
\text { Burrows }\end{array}$ & $\begin{array}{c}\text { Small } \\
\text { Mammal } \\
\text { Burrows }\end{array}$ & $\begin{array}{c}\text { Small } \\
\text { Mammal } \\
\text { Burrows }\end{array}$ & -- & -- \\
\hline \multicolumn{2}{|c|}{ Erosion Classification } & -- & Stable & Stable & Stable & Stable & Stable & -- & -- \\
\hline
\end{tabular}

Note: Scientific names of plants are listed in Appendix F-1.

Note: Erosion Classification Chart included in Appendix F-2.

\subsubsection{Plant Diversity}

Shrub and grass diversity has not fluctuated significantly since 2003. Shrub diversity remains within at approximately 1.5 species. Indian ricegrass was present in 2006 for the first time since 2003.

Table 6. Diversity of Perennial Plant Species on CAU 400, Bomblet Pit

\begin{tabular}{|c|c|c|c|c|c|c|c||}
\hline & $\mathbf{2 0 0 0}$ & $\mathbf{2 0 0 2}$ & $\mathbf{2 0 0 3}$ & $\mathbf{2 0 0 4}$ & $\mathbf{2 0 0 5}$ & $\mathbf{2 0 0 6}$ & Reference \\
\hline \hline Shrubs & 2.5 & 2.1 & 1.9 & 1.7 & 1.7 & 1.6 & 1.8 \\
\hline Grasses & 1.6 & 0.1 & 0.2 & 0.0 & 0.0 & 0.1 & 0.1 \\
\hline Forbs/Annuals & 1.3 & 0.2 & 0.1 & 0.5 & 1.5 & 0.0 & 0.4 \\
\hline $\begin{array}{c}\text { Average Number of Species } \\
\text { per Square Meter }\end{array}$ & 5.4 & 2.4 & 2.2 & 2.1 & 3.1 & 1.7 & 2.2 \\
\hline
\end{tabular}

\subsubsection{Summary}

Overall plant cover exceeded the standard for revegetation success and has met those standards for the last several years. Shrub cover in 2006 is more than double the standard. Grass cover 
remained at 0 percent, which does not meet the standard. Perennial plant density remains approximately 6 plants per $\mathrm{m}^{2}$, which is higher than the density on the reference area and approximately two times the standard of 2.9 plants per $\mathrm{m}^{2}$. Both shrub and grass densities exceed the standard for reclamation success. No forbs were encountered in 2006; however, forb densities fluctuate widely, making it a less reliable means of measuring reclamation success. Halogeton, a noxious weed that dominated the area prior to closure at a maximum density of 27.4 plants per $\mathrm{m}^{2}$ in 1999 , declined to 0.1 plants per $\mathrm{m}^{2}$ from 2002 to 2004 and has not been found on the site since 2004.

The only concern at this site is the lack of grasses. After revegetation there was an abundance of grasses. Since then grasses have gradually declined. The reappearance of Indian ricegrass this year is encouraging. With favorable growing conditions in the future, native grasses like Indian ricegrass may become established and contribute more to overall plant cover and density. Shrubs have become well established as indicated by higher cover values and densities than shrubs on the reference area. The fence has protected the shrubs and grasses from the impacts of grazing animals. Removal of the fence may decrease the potential for the grasses to establish on the site. In the event the fence is removed, it would be beneficial to evaluate the site periodically to document the effect, if any, of removing the fence. 


\section{CAU 400, BOMBLET PIT, PHOTOGRAPHIC REFERENCE}

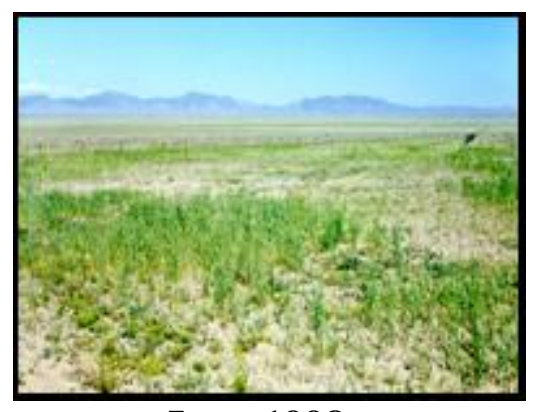

JUNE 1998

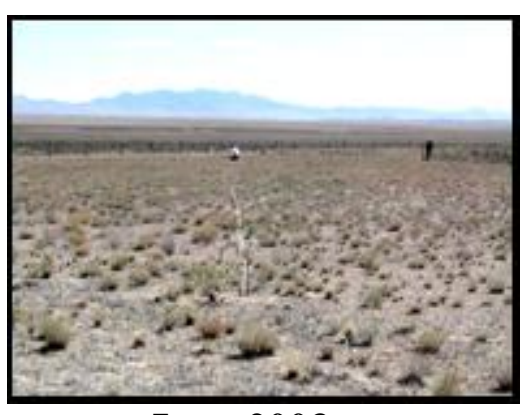

JUNE 2003

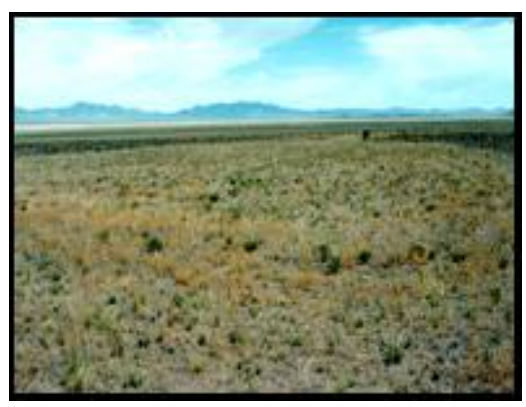

JUNE 2000

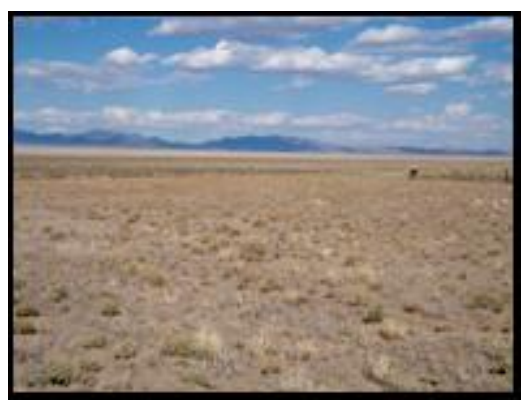

JUNE 2004

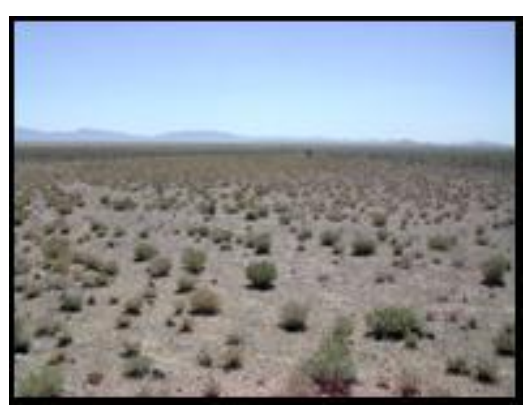

JUNE 2002

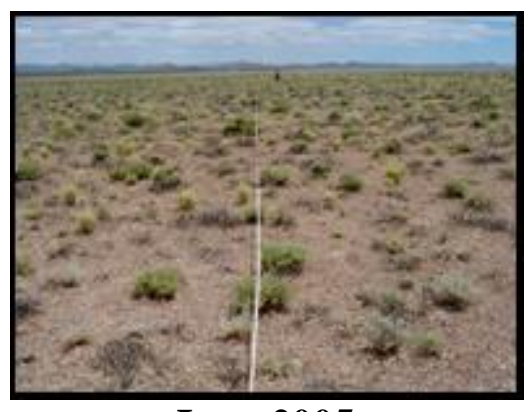

JUNE 2005

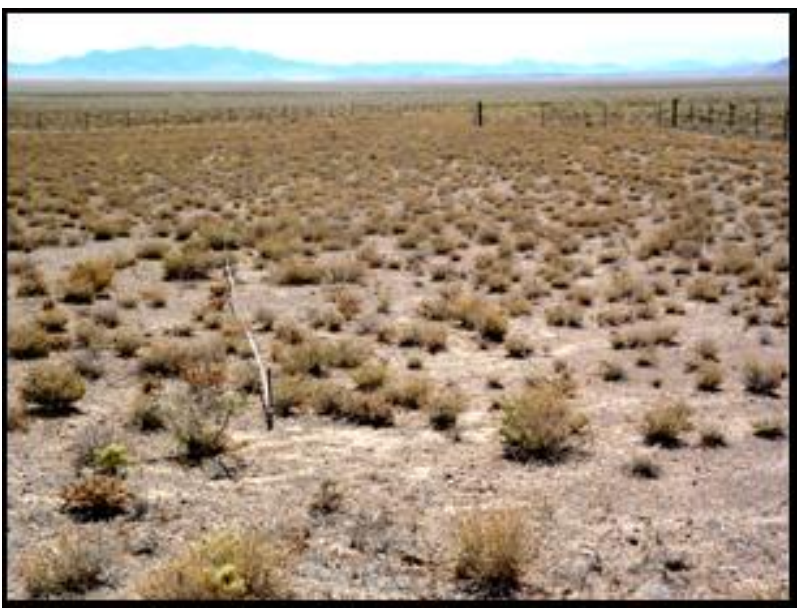

JUNE 2006 


\subsection{CAU 404, Staging Area, Results}

\subsubsection{Plant Cover}

Overall plant cover on the staging area of CAU 404 decreased from 2005 to 2006, mainly as a result of a decrease in annual forb cover. There was no significant change in shrub cover, which remains at its high. Grass cover doubled from 2005 to 2006 and, like shrub cover, is the highest it has been since 2000. Annual forb cover decreased by approximately 70 percent from 2005 to 2006. 2005 was the first year forbs contributed to overall plant cover.

Table 7. Plant Cover (\%) on CAU 404, Staging ARea

\begin{tabular}{|c|c|c|c|c|c|c|c|c||}
\hline \hline & $\mathbf{2 0 0 0}$ & $\mathbf{2 0 0 2}$ & $\mathbf{2 0 0 3}$ & $\mathbf{2 0 0 4}$ & $\mathbf{2 0 0 5}$ & $\mathbf{2 0 0 6}$ & Reference & Standard \\
\hline \hline Shrubs & 9.0 & 18.5 & 13.6 & 17.0 & 19.5 & 19.4 & 11.1 & 7.8 \\
\hline Grasses & 3.5 & 0.5 & 0.5 & 0.0 & 0.5 & 1.1 & 2.8 & 1.9 \\
\hline Forbs/Annuals & 0.0 & 0.0 & 0.0 & 0.0 & 3.5 & 1.1 & 3.3 & 2.3 \\
\hline Total Plant Cover & $\mathbf{1 2 . 5}$ & $\mathbf{1 9 . 0}$ & $\mathbf{1 4 . 1}$ & $\mathbf{1 7 . 0}$ & $\mathbf{2 3 . 5}$ & $\mathbf{2 1 . 6}$ & $\mathbf{1 7 . 2}$ & $\mathbf{1 2 . 0}$ \\
\hline Bare Ground & 56.5 & 53.0 & 69.3 & 61.5 & 69.0 & 56.2 & 55.0 & -- \\
\hline Litter & 31.0 & 28.0 & 16.6 & 21.5 & 7.5 & 22.2 & 27.8 & -- \\
\hline
\end{tabular}

\subsubsection{Plant Density}

Total plant density decreased from its high of 31.8 plants per $\mathrm{m}^{2}$ in 2005 to 8.1 plants per $\mathrm{m}^{2}$ in 2006. The density of just perennials (shrubs and grasses) increased from 6.5 plants per $\mathrm{m}^{2}$ in 2005 to 7.3 plants per $\mathrm{m}^{2}$ in 2006. There was a slight decrease in the density of grasses, but shrubs increased from 6.2 plants per $\mathrm{m}^{2}$ in 2005 to 7.1 plants per $\mathrm{m}^{2}$ in 2006, which is the first increase in shrub density since the site was revegetated. Bud sagebrush increased from 0.6 plants per $\mathrm{m}^{2}$ in 2005 to 1.6 plants per $\mathrm{m}^{2}$ in 2006. This is encouraging because bud sagebrush has decreased since 2000. Bud sagebrush is a major constituent of the native vegetation surrounding the site. Although grass density decreased in 2006, Indian ricegrass was encountered, which had decreased dramatically from 2000 to 2003. The density of annual forbs has fluctuated from 0.7 to 25 plants per $\mathrm{m}^{2}$ since 2000 .

There are several small mammal burrows scattered over the site. There is no indication that rabbits are heavily browsing the plants on the site. The only indication of erosion is around the main gate. There was some overland water flow several years ago, but there are no recent signs of erosion. 
Table 8. Plant Density (Plants Per M $^{2}$ ) On CAU 404, Staging Area

\begin{tabular}{|c|c|c|c|c|c|c|c|c|c|}
\hline & & 2000 & 2002 & 2003 & 2004 & 2005 & 2006 & Reference & Standard \\
\hline \multirow{4}{*}{ Shrubs } & Bud Sagebrush & 1.7 & 1.2 & 0.8 & 0.6 & 0.6 & 1.6 & 2.6 & -- \\
\hline & Fourwing Saltbush & 0.3 & 0.2 & 0.1 & 0.1 & 0.1 & 0.0 & 0.0 & -- \\
\hline & Shadscale & 10.0 & 6.9 & 5.5 & 5.4 & 5.4 & 5.3 & 0.8 & -- \\
\hline & Winterfat & 0.0 & 0.1 & 0.1 & 0.1 & 0.1 & 0.1 & 0.1 & -- \\
\hline \multicolumn{2}{|c|}{ Total Shrubs } & 12.0 & 8.4 & 6.5 & 6.2 & 6.2 & 7.0 & 3.5 & 2.4 \\
\hline \multirow{4}{*}{ Grasses } & Low Woolygrass & 0.0 & 0.0 & 0.0 & 0.0 & 0.0 & 0.0 & 0.3 & -- \\
\hline & Squirreltail & 6.2 & 0.1 & 0.0 & 0.0 & 0.0 & 0.0 & 0.0 & -- \\
\hline & Galleta & 0.8 & 0.3 & 0.2 & 0.1 & 0.2 & 0.1 & 0.8 & -- \\
\hline & Indian Ricegrass & 2.5 & 0.5 & 0.0 & 0.1 & 0.0 & 0.1 & 0.3 & -- \\
\hline \multicolumn{2}{|c|}{ Total Grasses } & 9.5 & 0.9 & 0.2 & 0.2 & 0.2 & 0.2 & 1.4 & 1.0 \\
\hline \multicolumn{2}{|c|}{ Total Forbs/Annuals } & 3.5 & 0.7 & 0.7 & 1.9 & 25.3 & 0.8 & 3.3 & 2.3 \\
\hline \multicolumn{2}{|c|}{ Total Plant Density } & 25.0 & 10.0 & 7.4 & 8.3 & 31.7 & 8.0 & 8.2 & 5.7 \\
\hline \multicolumn{2}{|c|}{ Wildlife Use } & Burrows & Burrows & Burrows & Burrows & Burrows & Burrows & -- & -- \\
\hline \multicolumn{2}{|c|}{ Erosion Classification } & Stable & Slight & Slight & Stable & Stable & Stable & -- & -- \\
\hline
\end{tabular}

Note: Scientific names of plants are listed in Appendix F-1.

Note: Erosion Classification Chart included in Appendix F-2.

\subsubsection{Plant Diversity}

Shrub diversity increased in 2006 but is not significantly different than previous years. A similar pattern has occurred for grasses. There was a decline from 2002 to 2003, but it has been steady since 2003. The diversity of annual forbs ranged from 0.2 species in 2003 to a high of 1.3 species in 2005. Overall plant diversity is stable and has not shown significant changes since 2002.

Table 9. Diversity of Perennial Plant Species on CAU 404, Staging Area

\begin{tabular}{|c|c|c|c|c|c|c|c||}
\hline & $\mathbf{2 0 0 0}$ & $\mathbf{2 0 0 2}$ & $\mathbf{2 0 0 3}$ & $\mathbf{2 0 0 4}$ & $\mathbf{2 0 0 5}$ & $\mathbf{2 0 0 6}$ & Reference \\
\hline \hline Shrubs & 2.0 & 1.7 & 1.6 & 1.5 & 1.4 & 1.8 & 1.7 \\
\hline Grasses & 2.2 & 0.6 & 0.2 & 0.1 & 0.1 & 0.1 & 0.5 \\
\hline Forbs/Annuals & 0.6 & 0.4 & 0.2 & 0.6 & 1.3 & 0.4 & 1.2 \\
\hline $\begin{array}{c}\text { Average Number of Species } \\
\text { per Square Meter }\end{array}$ & 4.8 & 2.7 & 2.0 & 2.2 & 2.8 & 2.3 & 3.4 \\
\hline
\end{tabular}




\subsubsection{Summary}

Halogeton, a noxious weed, has been found on the staging area as well as in the native plant community. The density of halogeton was 3.0 plants per $\mathrm{m}^{2}$ the first year after revegetation, decreased to 0.5 plants per $\mathrm{m}^{2}$ the following year, showed a slight increase over the next 3 years to a high of 1.6 plants per $\mathrm{m}^{2}$ in 2004 , decreased to 0.1 plants per $\mathrm{m}^{2}$ in 2005 , and was not encountered in 2006. The establishment of both perennial and annual native plants has been the best control measure for this noxious weed.

Overall plant cover and plant diversity on the staging area at CAU 404 exceeds the standards used to determine revegetation success. However, when considering individual life-forms, grasses do not meet success standards. Shrub cover and density is more than two times the standards established for shrubs. Grass cover on the staging area is approximately 60 percent of the standard. The density of grasses is 20 percent of the standard. Shrub cover and density have been consistently higher than the reference area for the last several years, indicating that they have successfully established on the site. The increase in bud sagebrush this year is very encouraging. This species is an important component of the native vegetation and had declined in density over the last few years. This is the first year density of bud sagebrush has increased.

Plant cover and density are higher on the revegetated area than on the adjacent undisturbed reference area. However, grasses have not met revegetation standards for either cover or density. Removal of the fence at this time may put stress on the grasses because they would be exposed to grazing animals, and the vigor and abundance of grasses may decline to a point where they may not meet standards set to determine revegetation success. 


\section{CAU 404, ROLLER COASTER LAgOONS AND TRENCH, Staging Area, PHotographic Reference}

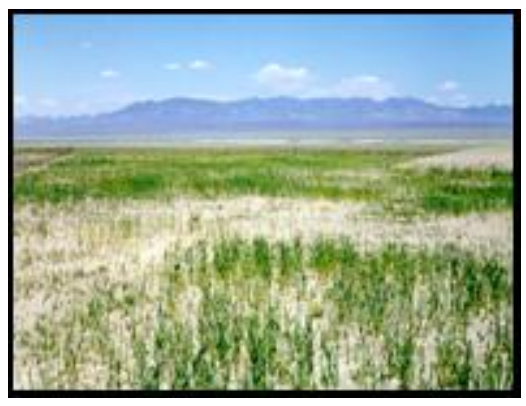

JUNE 1998

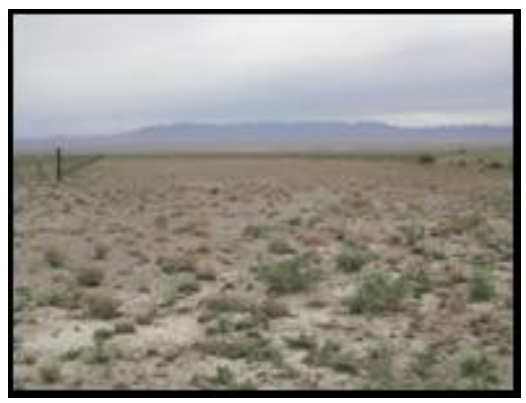

SEPTEMBER 2003

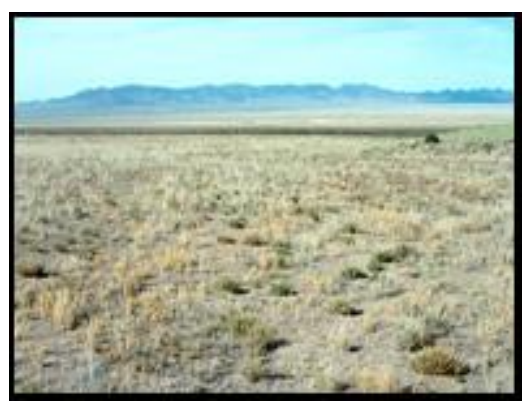

JUNE 2000

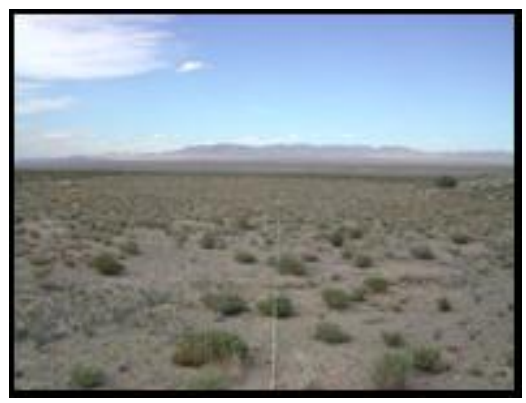

JUNE 2004

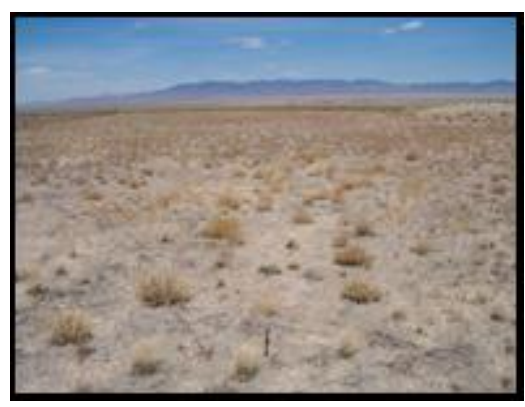

JUNE 2002

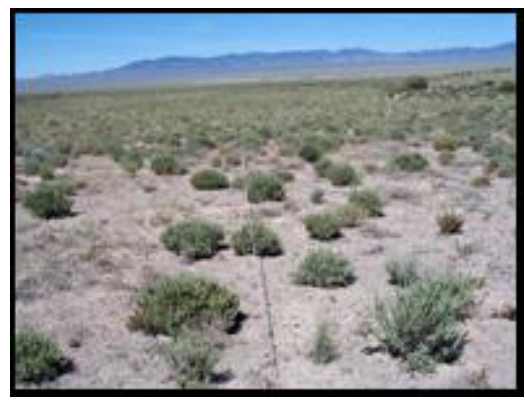

JUNE 2005

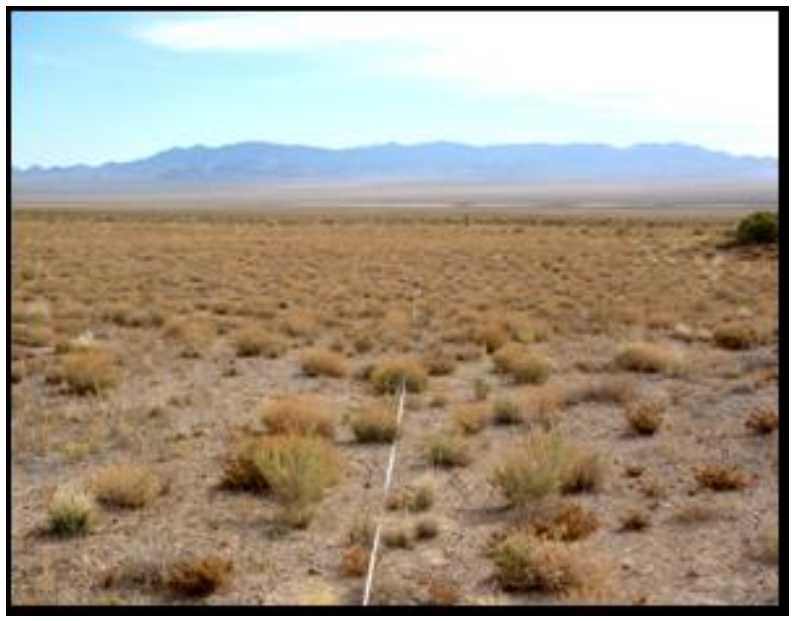

JUNE 2006 


\subsection{CAU 404, Cover, Results}

\subsubsection{Plant Cover}

Total plant cover on this site decreased from 36.3 percent in 2005 to 25.6 percent in 2006. Shrub cover and annual forb cover both decreased in 2006; however, grass cover increased. Although shrub cover decreased to 13.4 percent, this is the second highest amount of shrub cover since the site was revegetated. Grass cover has steadily increased from the low of 3.8 percent in 2004. Forbs have only contributed to overall cover for two of the 6 years on monitoring.

Table 10. Plant Cover (\%) ON CAU 404, Cover

\begin{tabular}{|c|c|c|c|c|c|c|c|c||}
\hline & $\mathbf{2 0 0 0}$ & $\mathbf{2 0 0 2}$ & $\mathbf{2 0 0 3}$ & $\mathbf{2 0 0 4}$ & $\mathbf{2 0 0 5}$ & $\mathbf{2 0 0 6}$ & Reference & Standard \\
\hline \hline Shrubs & 6.3 & 10.0 & 12.5 & 10.0 & 18.8 & 13.4 & 11.1 & 7.8 \\
\hline Grasses & 12.5 & 16.3 & 10.0 & 3.8 & 10.0 & 12.2 & 2.8 & 1.9 \\
\hline Forbs/Annuals & 0.0 & 0.0 & 0.0 & 1.3 & 7.5 & 0.0 & 3.3 & 2.3 \\
\hline Total Plant Cover & $\mathbf{1 8 . 8}$ & $\mathbf{2 6 . 3}$ & $\mathbf{2 2 . 5}$ & $\mathbf{1 5 . 1}$ & $\mathbf{3 6 . 3}$ & $\mathbf{2 5 . 6}$ & $\mathbf{1 7 . 2}$ & $\mathbf{1 2 . 0}$ \\
\hline Bare Ground & 73.7 & 64.9 & 71.2 & 77.4 & 57.4 & 66.0 & 55.0 & -- \\
\hline Litter & 7.5 & 8.8 & 6.3 & 7.5 & 6.3 & 8.4 & 27.8 & -- \\
\hline
\end{tabular}

\subsubsection{Plant Density}

There has been a gradual decline in the density of shrubs and grasses since the site was revegetated. There was an increase in shrub density in 2005, but the 6.3 shrubs per $\mathrm{m}^{2}$ recorded for 2006 is the lowest shrub density recorded to date. A similar trend has occurred for grasses. The decrease in plant density from 2005 to 2006 has been a result of decrease in the density of fourwing saltbush, shadscale, and galleta grass.

As noted in previous years, there continues to be a number of small mammal burrows around the periphery of the cover berm. The presence of the burrows indicates use of the site by native wildlife species. Increased erosion due to the burrowing activity was not seen in 2006, nor has it been an issue in previous years. There was some overland flooding along the southern edge of the berm, but no channeling or furrowing has been observed. 
TABle 11. Plant Density (Plants Per $\mathrm{M}^{2}$ ) ON CAU 404, CoVer

\begin{tabular}{|c|c|c|c|c|c|c|c|c|c|}
\hline & & 2000 & 2002 & 2003 & 2004 & 2005 & 2006 & Reference & Standard \\
\hline \multirow{4}{*}{ Shrubs } & Bud Sagebrush & 2.1 & 1.7 & 1.2 & 1.0 & 0.9 & 0.8 & 2.6 & -- \\
\hline & Fourwing Saltbush & 0.9 & 0.6 & 0.3 & 0.5 & 0.6 & 0.3 & 0.0 & -- \\
\hline & Shadscale & 10.9 & 7.0 & 7.0 & 5.9 & 6.6 & 5.1 & 0.8 & -- \\
\hline & Winterfat & 0.3 & 0.1 & 0.0 & 0.0 & 0.0 & 0.1 & 0.1 & -- \\
\hline \multicolumn{2}{|c|}{ Total Shrubs } & 14.2 & 9.4 & 8.5 & 7.4 & 8.1 & 6.3 & 3.5 & 2.4 \\
\hline \multirow{4}{*}{ Grasses } & Low Woolygrass & 0.0 & 0.0 & 0.0 & 0.0 & 0.0 & 0.0 & 0.3 & -- \\
\hline & Squirreltail & 10.8 & 1.6 & 0.1 & 0.0 & 0.1 & 0.0 & 0.0 & -- \\
\hline & Galleta & 8.6 & 4.7 & 4.9 & 5.2 & 5.1 & 4.4 & 0.8 & -- \\
\hline & Indian Ricegrass & 3.8 & 2.8 & 1.1 & 0.6 & 0.2 & 0.3 & 0.3 & -- \\
\hline \multicolumn{2}{|c|}{ Total Grasses } & 23.2 & 9.1 & 6.1 & 5.8 & 5.4 & 4.7 & 1.4 & 1.0 \\
\hline \multicolumn{2}{|c|}{ Total Forbs/Annuals } & 0.5 & 0.3 & 0.2 & 1.9 & 31.5 & 0.5 & 3.3 & 2.3 \\
\hline \multicolumn{2}{|c|}{ Total Plant Density } & 37.9 & 18.8 & 14.8 & 15.1 & 45.0 & 11.5 & 8.2 & 5.7 \\
\hline \multicolumn{2}{|c|}{ Wildlife Use } & Burrows & Burrows & Burrows & Burrows & Burrows & Burrows & -- & -- \\
\hline \multicolumn{2}{|c|}{ Erosion Classification } & Stable & Slight & Slight & Stable & Stable & Stable & -- & -- \\
\hline
\end{tabular}

Note: Scientific names of plants are listed in Appendix F-1.

Note: Erosion Classification Chart included in Appendix F-2.

\subsubsection{Plant Diversity}

The diversity of shrubs on the cover has been approximately unchanged since 2002. The diversity of grasses has shown a gradual decline since revegetation occurred and appears to have stabilized at approximately 1.3 species per $\mathrm{m}^{2}$. With the lack of annual forbs in 2006, overall plant diversity decreased to the lowest value since the site was revegetated.

Table 12. Diversity of Perennial Plant Species on CAU 404, Cover

\begin{tabular}{|c|c|c|c|c|c|c|c||}
\hline & $\mathbf{2 0 0 0}$ & $\mathbf{2 0 0 2}$ & $\mathbf{2 0 0 3}$ & $\mathbf{2 0 0 4}$ & $\mathbf{2 0 0 5}$ & $\mathbf{2 0 0 6}$ & Reference \\
\hline \hline Shrubs & 2.5 & 2.1 & 1.8 & 2.0 & 2.0 & 1.8 & 1.7 \\
\hline Grasses & 3.0 & 2.7 & 1.8 & 1.4 & 1.3 & 1.3 & 0.5 \\
\hline Forbs/Annuals & 0.4 & 0.3 & 0.2 & 0.6 & 1.7 & 0.2 & 1.2 \\
\hline $\begin{array}{c}\text { Average Number of Species } \\
\text { per Square Meter }\end{array}$ & 5.9 & 5.1 & 3.7 & 4.0 & 5.0 & 3.2 & 3.4 \\
\hline
\end{tabular}




\subsubsection{Summary}

Revegetation standards established for the cover of CAU 404 have been met. Both shrub cover and grass cover exceed the standards. Shrub cover is nearly twice the standard, and grass cover is more than six times the standard. Shrub and grass densities also exceed revegetation standards. Shrub density is more than two and a half times the standard. Grass density is nearly five times the standard.

Removal of the fence at this site may not have as detrimental effect on the cover as on the staging area because of the excellent mix of native shrubs and grasses that have established on the cover. Plant density and vigor may decline with unrestricted access for both horses and antelope. 


\section{CAU 404, ROLLER COASTER LAgOONS AND TRENCH, COVER, PHOTOGRAPHIC REFERENCE}

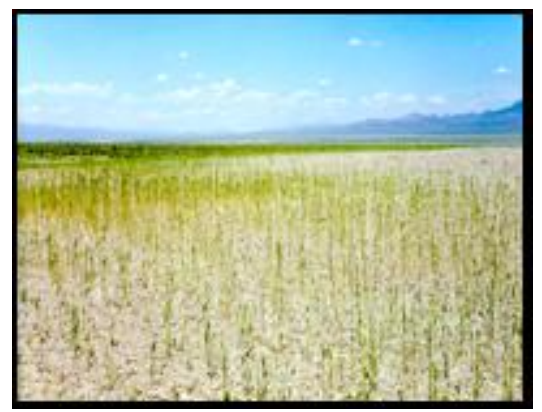

JUNE 1998

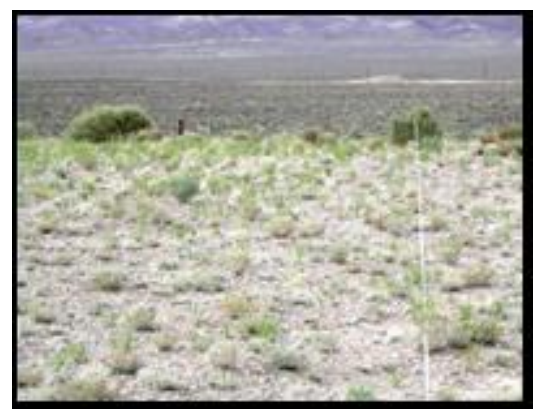

JUNE 2003

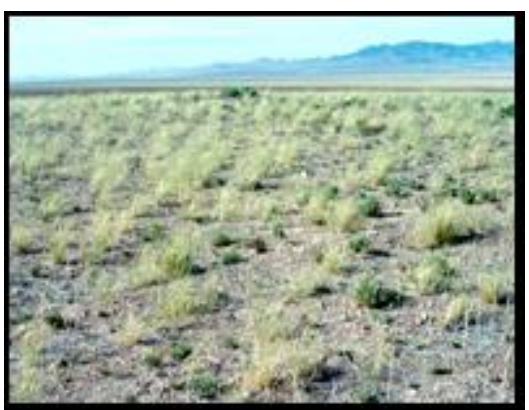

JUNE 2000

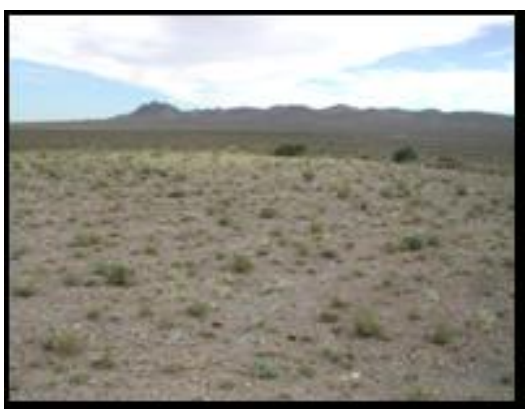

JUNE 2004

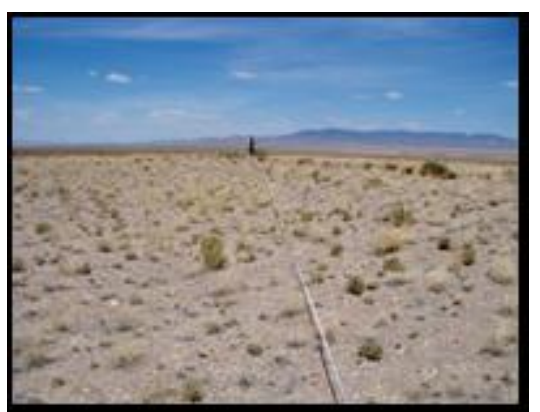

JUNE 2002

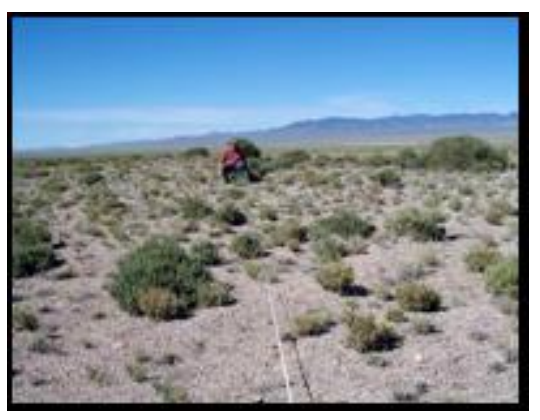

JUNE 2005

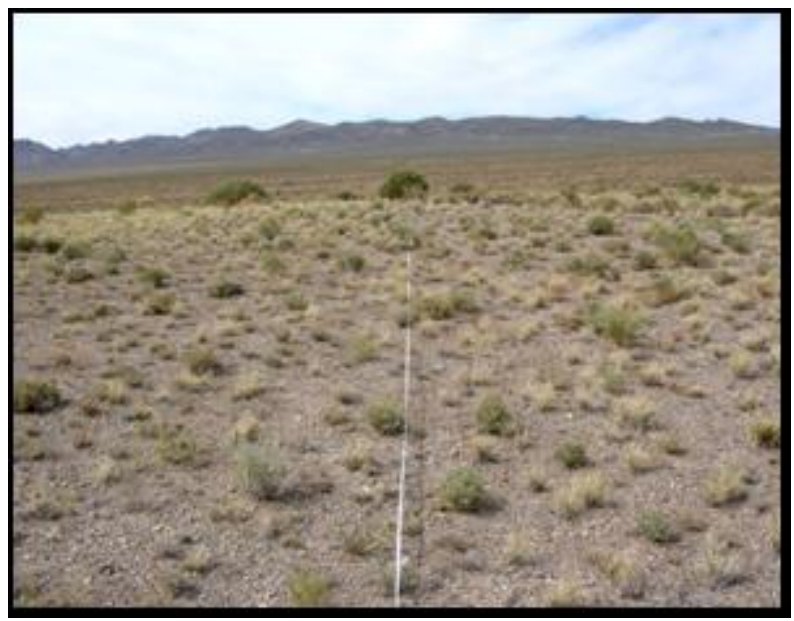

JUNE 2006 


\subsection{CAU 407 Results}

\subsubsection{Plant Cover}

2006 is the second year the vegetation has been sampled at this site. Plant density was recorded in 2005, and plant cover and density were recorded in 2006. Total plant cover was 25.8 percent in 2006, which is higher than the reference area. This is to be expected on newly revegetated sites, where there is an abundance of young plants, many from seedlings from 2005 and some from seeds that germinated in 2006. The majority of the cover is from young shrubs and grasses. Unlike in 2005 when there was an abundance of annual forbs, the shrubs and grasses now dominate the site. Over 60 percent of the total plant cover is from young shrubs, and 36 percent of the total plant cover is from grasses. Bare ground accounts for 0 percent of the site. Straw netting, which accounts for litter on the site, was placed on the site to reduce the flow of water and soil erosion, and promote seed germination by retaining soil moisture.

Table 13. Plant Cover (\%) ON CAU 407

\begin{tabular}{||c|c|c|}
\hline & $\mathbf{2 0 0 6}$ & Reference \\
\hline \hline Shrubs & 15.8 & 11.1 \\
\hline Grasses & 9.2 & 2.8 \\
\hline Forbs/Annuals & 0.8 & 3.3 \\
\hline Total Plant Cover & $\mathbf{2 5 . 8}$ & $\mathbf{1 7 . 2}$ \\
\hline Bare Ground & 0.0 & 55.0 \\
\hline Litter & 74.2 & 27.8 \\
\hline
\end{tabular}

\subsubsection{Plant Density}

Plant density on the site remains high in comparison to the density of plants in the native vegetation on the reference area. Plant density, including annual forbs, increased from 84 plants per $\mathrm{m}^{2}$ in 2005 to 86 plants per $\mathrm{m}^{2}$ in 2006. These high plant densities are not expected to be maintained. As the young plants begin to grow and mature and the demand for water and nutrients increases, there will be a natural thinning of the plants, and only the most hardy and vigorous will survive. Fourwing saltbush and shadscale are still the most dominant species on the site. There was a decrease in the number bud sagebrush seedlings, and the density of winterfat doubled. The density of Indian ricegrass declined significantly from 2005 to 2006, but squirreltail grass increased by about 24 percent. All shrubs and grasses were young seedlings and very few, if any, will flower and set seed.

There are numerous small mammal burrows along the southern and western sides of the site (Figure 1). No burrows were seen on the top of the cover. The surface soils on the site are compacted and may not have been penetrable by the small mammals. Based on the color of the soils that had been brought to the surface at burrow entrances, it appears that the animals are only penetrating the fill material used in cover construction.

Eliminating burrowing activity on the site would be difficult. To do so would require surrounding the site with an exclusion fence, consisting of a metal flashing or small hardware mesh 36 inches high and buried 6 to 10 inches deep. Once the fence is in place, trapping would 
be required to remove the animals that are inside the fence. Another option would be to cover areas where burrowing activity is occurring (the side slopes) with a hardware mesh or geotextile fabric. Another option would be to monitor the burrows and the soil that is being brought to the surface. Currently, the soil being moved to the surface is the fill material, indicating the animals are not moving into the native soil. During monitoring, if native soil is being moved to the surface, action should be taken. Another option would be to conduct regular sampling of the biota and soil to determine if either is contaminated. If either is found to be contaminated, then appropriate action should be taken.

Table 14. Plant Density (PLANTS Per $\mathrm{M}^{2}$ ) ON CAU 407

\begin{tabular}{|c|c|c|c|c|}
\hline & & 2005 & 2006 & Reference \\
\hline \multirow{5}{*}{ Shrubs } & Bud Sagebrush & 2.9 & 1.3 & 2.6 \\
\hline & Fourwing Saltbush & 2.3 & 3.2 & 0.0 \\
\hline & Shadscale & 17.5 & 17.9 & 0.8 \\
\hline & Rubber Rabbitbrush & 0.0 & 0.3 & -- \\
\hline & Winterfat & 0.7 & 2.0 & 0.1 \\
\hline \multicolumn{2}{|c|}{ Total Shrubs } & 23.4 & 24.7 & 3.5 \\
\hline \multirow{3}{*}{ Grasses } & Squirreltail & 42.9 & 53.3 & 0.0 \\
\hline & Galleta & 0.0 & 0.0 & 0.8 \\
\hline & Indian Ricegrass & 16.4 & 1.1 & 0.3 \\
\hline \multicolumn{2}{|c|}{ Total Grasses } & 59.3 & 54.4 & 1.1 \\
\hline \multicolumn{2}{|c|}{ Total Forbs/Annuals } & 1.4 & 7.3 & 3.3 \\
\hline \multicolumn{2}{|c|}{ Total Plant Density } & 84.1 & 86.4 & 7.9 \\
\hline \multicolumn{2}{|c|}{ Wildlife Use } & Small Mammal Burrows & Small Mammal Burrows & -- \\
\hline \multicolumn{2}{|c|}{ Erosion Classification } & Stable & Stable & -- \\
\hline
\end{tabular}

Note: Scientific names of plants are listed in Appendix F-1.

Note: Erosion Classification Chart included in Appendix F-2.

\subsubsection{Plant Diversity}

Plant diversity was recorded in 2006 to document that there is a good mix of species establishing on the site. Diversity is high and, like plant density, will decline to levels similar to those on the reference area. 
Table 15. Diversity of Perennial Plant Species on CAU 407

\begin{tabular}{|c|c|c|c|}
\hline & $\mathbf{2 0 0 5}$ & $\mathbf{2 0 0 6}$ & Reference \\
\hline \hline Shrubs & 2.5 & 3.4 & 1.7 \\
\hline Grasses & 1.1 & 1.6 & 0.5 \\
\hline Forbs & 0.8 & 0.4 & 1.2 \\
\hline $\begin{array}{c}\text { Average Number of Species } \\
\text { per Square Meter }\end{array}$ & 4.4 & 5.4 & 3.4 \\
\hline
\end{tabular}

\subsubsection{Summary}

There is an abundance of old, dead stalks of halogeton (Figure 2) from the abudant rainfall in 2005. Halogeton is very common along roadsides and almost any place that has been disturbed, and is characterized by succulent, fleshy leaves and a central reddish stem. The number of plants has decreased by approximately 50 percent from 2005 to 2006. A similar trend has been observed at other revegetated sites, where halogeton becomes less abundant as native plants become established.

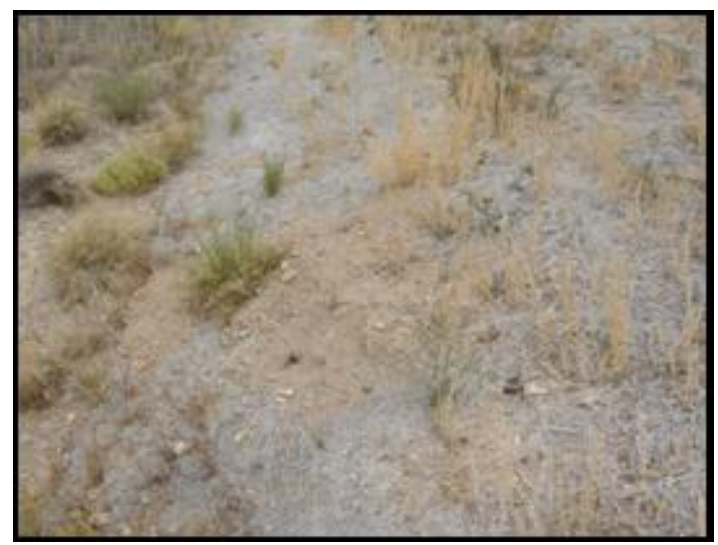

Figure 1. Small mammal burrows along the edge of the cover at CAU 407

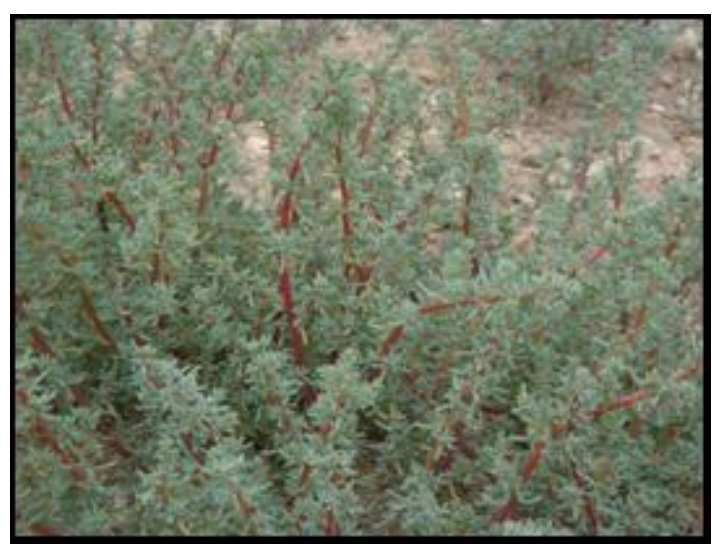

Figure 2. Halogeton (Halogeton glomeratus) 


\section{CAU 407, Roller CoAster RADSAFE AREA, Photographic REFERENCE}

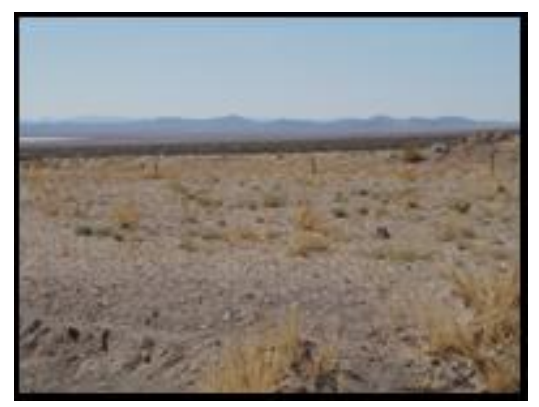

JUNE 2002

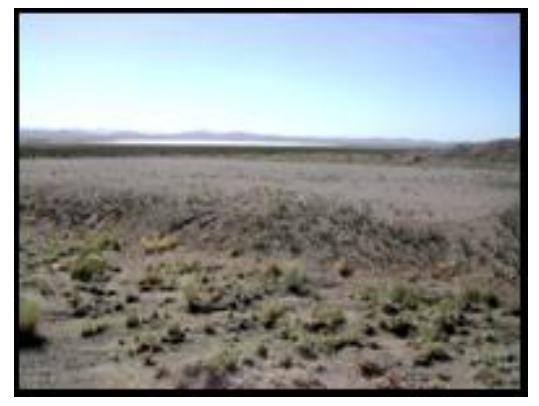

JUNE 2004

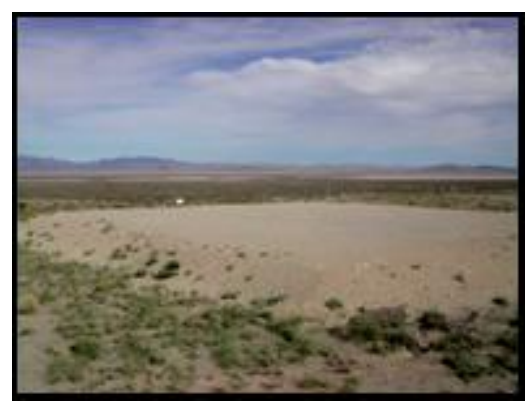

SEPTEMBER 2003

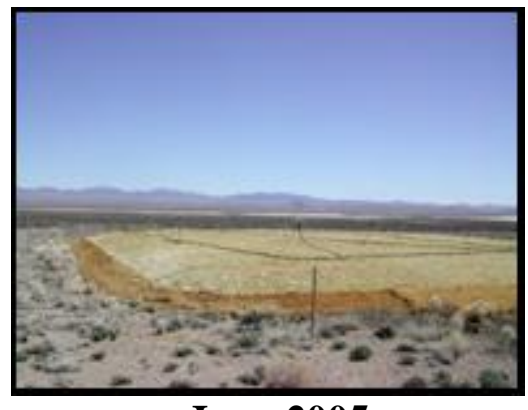

JUNE 2005

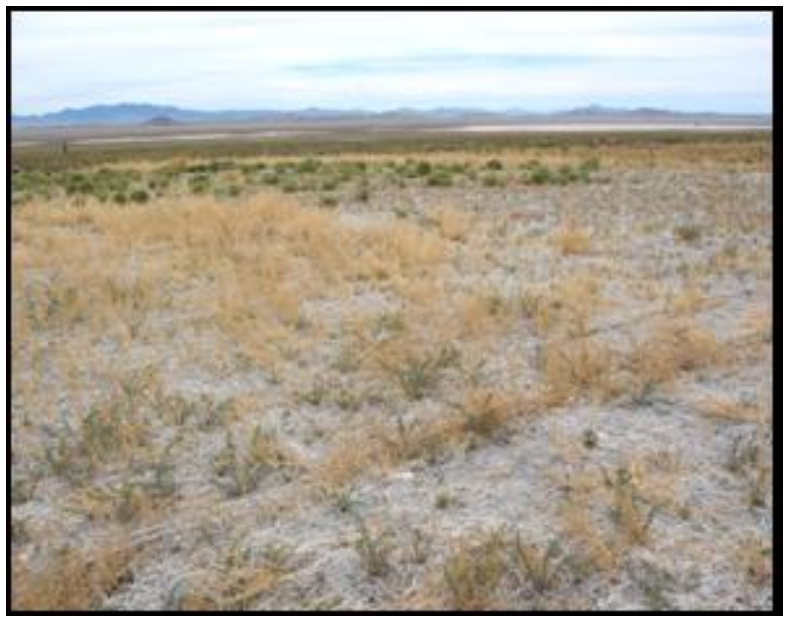

JUNE 2006 


\subsection{CAU 426, Staging Area, Results}

\subsubsection{Plant Cover}

Combined shrub and grass cover continues to be high on the staging area at CAU 426. The amount of shrub cover in 2006 was approximately equal to 2005, which was the highest value since the site was revegetated. The amount of grass cover also continues to be high, but it decreased from 17.1 percent in 2005 to 10.8 percent in 2006. In 2005, grasses responded to high levels of precipitation. There was no grass cover on the reference area in 2006, and in previous years, grass cover on the reference area has ranged between 1 and 2 percent. The lack of grasses on the reference area may be due to wild horses and other potential herbivores in the area. Forb cover decreased from the record high of 10.3 percent in 2005 to 1.7 percent in 2006, which was equal to the forb cover on the reference area.

Table 16. Plant Cover (\%) on CAU 426, Staging Area

\begin{tabular}{|c|c|c|c|c|c|c|c|c|}
\hline & $\mathbf{2 0 0 0}$ & $\mathbf{2 0 0 2}$ & $\mathbf{2 0 0 3}$ & $\mathbf{2 0 0 4}$ & $\mathbf{2 0 0 5}$ & $\mathbf{2 0 0 6}$ & Reference & Standard \\
\hline \hline Shrubs & 0.8 & 5.0 & 2.5 & 3.3 & 5.1 & 5.0 & 10.8 & 7.6 \\
\hline Grasses & 5.8 & 12.5 & 6.7 & 10.8 & 17.1 & 10.8 & 0.0 & 0.0 \\
\hline Forbs/Annuals & 0.0 & 1.7 & 5.0 & 2.5 & 10.3 & 1.7 & 1.7 & 1.2 \\
\hline Total Plant Cover & $\mathbf{6 . 6}$ & $\mathbf{1 9 . 2}$ & $\mathbf{1 4 . 2}$ & $\mathbf{1 6 . 6}$ & $\mathbf{3 2 . 5}$ & $\mathbf{1 7 . 5}$ & $\mathbf{1 2 . 5}$ & $\mathbf{8 . 8}$ \\
\hline Bare Ground & 50.1 & 42.5 & 50.0 & 59.2 & 47.0 & 50.0 & 75.0 & -- \\
\hline Litter & 43.3 & 38.3 & 35.8 & 24.2 & 20.5 & 32.5 & 12.5 & -- \\
\hline
\end{tabular}

\subsubsection{Plant Density}

The density of shrubs on the staging area has remained steady since 2000. The density of grasses has varied since 2000, but the 3.9 grasses per $\mathrm{m}^{2}$ was recorded in 2006, which is only slightly less than 2005, when above normal precipitation was received, and 2000, when there was an abundance of young seedlings. The number of annual forbs declined from 2005 to 2006, but is still higher than 2002, 2003 or 2004. The presence of an annual noxious weed, halogeton, is a concern. Of the 7.3 annual plants per $\mathrm{m}^{2}$ recorded in 2006, only 1.4 plants were halogeton, which is lower than in previous years.

Nevada jointfir is the most common shrub on the staging area. Douglas' rabbitbrush was also encountered, but at lower densities. The presence of shadscale and rubber rabbitbrush has been sporadic over the years, but both were found on the site in 2006. No fourwing saltbush or winterfat were found in 2006.

Squirreltail is the most common grass found on the staging area followed by Indian ricegrass and galleta grass. Plant densities for squirreltail and Indian ricegrass were lower in 2006 than in 2005, but there was an increase in the density of galleta grass.

There are a few small mammal burrows scattered over the staging area. There are no signs of erosion. 
Table 17. Plant Density (Plants Per M $^{2}$ ) On CAU 426, Staging Area

\begin{tabular}{|c|c|c|c|c|c|c|c|c|c|}
\hline & & 2000 & 2002 & 2003 & 2004 & 2005 & 2006 & Reference & Standard \\
\hline \multirow{8}{*}{ Shrubs } & Black Sagebrush & 0.0 & 0.1 & 0.0 & 0.0 & 0.0 & 0.0 & 0.8 & -- \\
\hline & Bud Sagebrush & 0.0 & 0.1 & 0.0 & 0.0 & 0.0 & 0.0 & 0.4 & -- \\
\hline & Fourwing Saltbush & 0.1 & 0.0 & 0.0 & 0.0 & 0.1 & 0.0 & 0.0 & -- \\
\hline & Shadscale & 0.1 & 0.0 & 0.0 & 0.1 & 0.0 & 0.1 & 0.3 & -- \\
\hline & Douglas' Rabbitbrush & 0.1 & 0.1 & 0.2 & 0.1 & 0.2 & 0.1 & 0.0 & -- \\
\hline & Nevada Jointfir & 0.3 & 0.2 & 0.3 & 0.1 & 0.3 & 0.4 & 0.0 & -- \\
\hline & Rubber Rabbitbrush & 0.1 & 0.0 & 0.1 & 0.1 & 0.0 & 0.1 & 0.0 & -- \\
\hline & Winterfat & 0.0 & 0.0 & 0.0 & 0.0 & 0.1 & 0.0 & 0.0 & -- \\
\hline \multicolumn{2}{|r|}{ Total Shrubs } & 0.7 & 0.5 & 0.6 & 0.4 & 0.7 & 0.7 & 1.5 & 1.0 \\
\hline \multirow{3}{*}{ Grasses } & Squirreltail & 5.2 & 2.9 & 0.6 & 1.9 & 5.1 & 3.1 & 0.1 & -- \\
\hline & Galleta & 0.2 & 0.1 & 0.0 & 0.3 & 0.0 & 0.2 & 3.0 & -- \\
\hline & Indian Ricegrass & 1.4 & 0.6 & 0.7 & 0.4 & 1.3 & 0.6 & 0.1 & -- \\
\hline \multicolumn{2}{|r|}{ Total Grasses } & 6.8 & 3.6 & 1.3 & 2.6 & 6.4 & 3.9 & 3.2 & 2.7 \\
\hline \multicolumn{2}{|c|}{ Total Forbs/Annuals } & 16.9 & 1.8 & 3.9 & 3.2 & 16.6 & 7.3 & 1.6 & 1.1 \\
\hline \multicolumn{2}{|c|}{ Total Plant Density } & 24.4 & 5.9 & 5.8 & 6.2 & 23.7 & 11.9 & 6.3 & 4.8 \\
\hline \multicolumn{2}{|r|}{ Wildlife Use } & -- & $\begin{array}{c}\text { Small } \\
\text { Mammal } \\
\text { Burrows } \\
\end{array}$ & $\begin{array}{c}\text { Small } \\
\text { Mammal } \\
\text { Burrows } \\
\end{array}$ & $\begin{array}{c}\text { Small } \\
\text { Mammal } \\
\text { Burrows } \\
\end{array}$ & $\begin{array}{c}\text { Small } \\
\text { Mammal } \\
\text { Burrows } \\
\end{array}$ & $\begin{array}{c}\text { Small } \\
\text { Mammal } \\
\text { Burrows } \\
\end{array}$ & -- & -- \\
\hline \multicolumn{2}{|c|}{ Erosion Classification } & -- & Stable & Stable & Stable & Stable & Stable & -- & -- \\
\hline
\end{tabular}

Note: Scientific names of plants are listed in Appendix F-1.

Note: Erosion Classification Chart included in Appendix F-2.

\subsubsection{Plant Diversity}

Plant diversity on the staging area in 2006 is the highest recorded since the site was revegetated. Diversity more than doubled for both shrub and grass species from 2005 to 2006. Forb diversity increased slightly from 2005 to 2006 but has been approximately unchanged since 2003.

Table 18. Diversity of Perennial Plant Species on CAU 426, Staging Area

\begin{tabular}{|c|c|c|c|c|c|c|c||}
\hline & $\mathbf{2 0 0 0}$ & $\mathbf{2 0 0 2}$ & $\mathbf{2 0 0 3}$ & $\mathbf{2 0 0 4}$ & $\mathbf{2 0 0 5}$ & $\mathbf{2 0 0 6}$ & Reference \\
\hline \hline Shrubs & 0.6 & 0.4 & 0.5 & 0.4 & 0.2 & 0.5 & 0.9 \\
\hline Grasses & 1.2 & 0.9 & 0.6 & 0.9 & 0.4 & 1.3 & 0.7 \\
\hline Forbs/Annuals & 0.9 & 0.4 & 1.1 & 1.3 & 1.1 & 1.3 & 0.6 \\
\hline $\begin{array}{c}\text { Average Number of Species } \\
\text { per Square Meter }\end{array}$ & 2.8 & 1.7 & 2.2 & 2.6 & 1.8 & 3.0 & 2.1 \\
\hline
\end{tabular}




\subsubsection{Summary}

The CAU 426 staging area is the only site monitored at the Tonopah Test Range where grass cover and density are higher than for shrubs. Usually shrubs are several times more abundant than grasses, but on the CAU 426 staging area, grass cover is twice shrub cover, and there are more than twice as many grasses per $\mathrm{m}^{2}$ as shrubs. Grass cover and density exceed the standards for reclamation success. Shrub density exceeds the standard for reclamation success, but shrub cover in 2006 was 5.0 percent compared to the standard of 7.6 percent.

This site was disturbed prior to closure activities, and halogeton, a noxious weed, occupied much of the area. Since revegetation, the density of halogeton has decreased from 15 plants per $\mathrm{m}^{2}$ in 2000 to 1.4 plants per $\mathrm{m}^{2}$ in 2006 . The abundance of this species is usually kept in check by the presence of native plant species and the absence of new soil disturbances. 


\section{CAU 426, CACTUS SPRING WASTE TRENCHES, Staging Area, Photographic RefEREnCE}

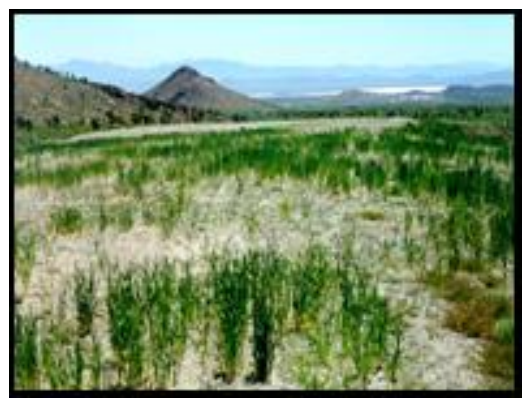

JUNE 1998

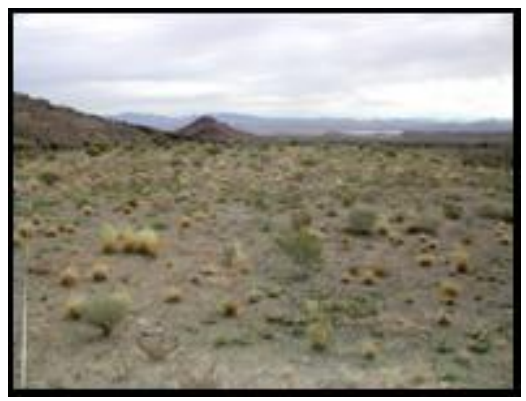

SEPTEMBER 2003

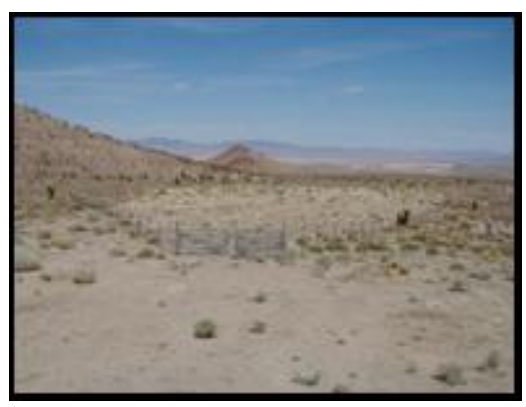

JUNE 2000

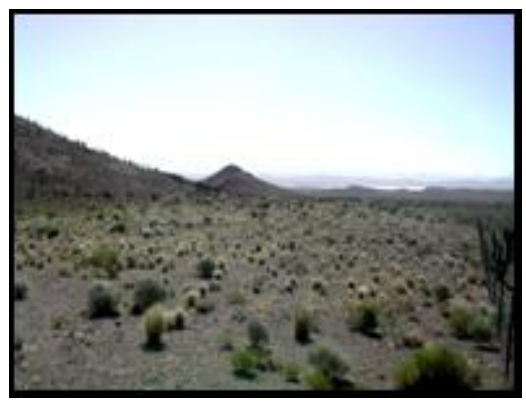

JUNE 2004

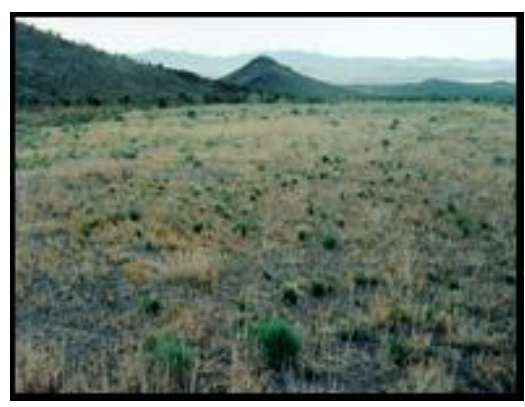

JUNE 2002

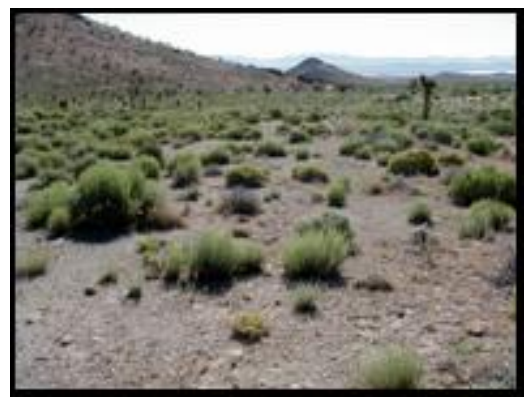

JUNE 2005

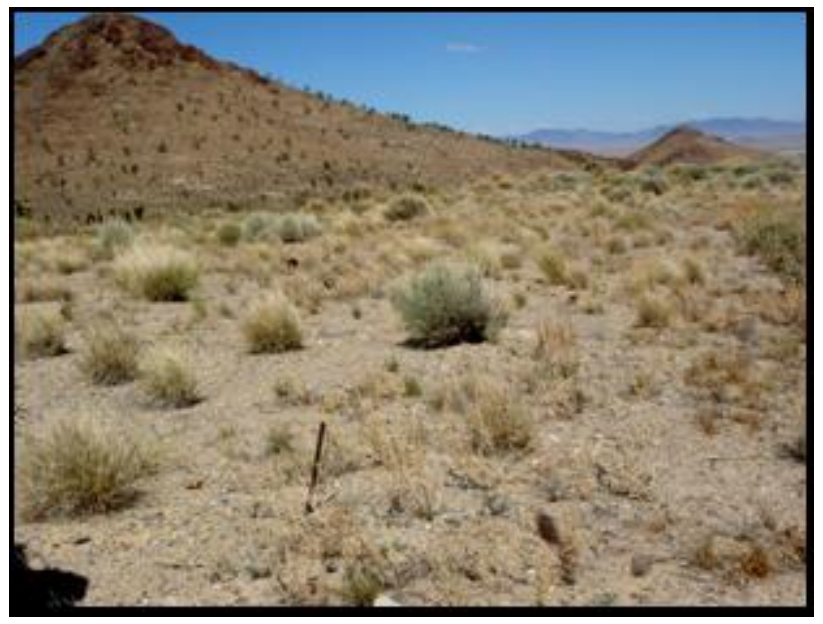

JUNE 2006 


\subsection{CAU 426, Cover, Results}

\subsubsection{Plant Cover}

The combined shrub and grass cover of 20 percent recorded in 2006 is the highest value recorded for the cover since the site was revegetated. Shrub cover in 2006 was approximately 11 percent higher than the previous high of 15 percent in 2003. Grass cover has increased from 0 percent in 2005 to 3.3 percent in 2006, but is still lower than 2004. Annual forbs only contributed to overall plant cover in 2005.

Table 19. Plant Cover (\%) ON CAU 426, Cover

\begin{tabular}{|c|c|c|c|c|c|c|c|c||}
\hline \hline & $\mathbf{2 0 0 0}$ & $\mathbf{2 0 0 2}$ & $\mathbf{2 0 0 3}$ & $\mathbf{2 0 0 4}$ & $\mathbf{2 0 0 5}$ & $\mathbf{2 0 0 6}$ & Reference & Standard \\
\hline \hline Shrubs & 0.0 & 6.7 & 15.0 & 10.0 & 10.0 & 16.7 & 10.8 & 7.6 \\
\hline Grasses & 3.3 & 8.3 & 1.7 & 6.7 & 0.0 & 3.3 & 0.0 & 0.0 \\
\hline Forbs/Annuals & 0.0 & 0.0 & 0.0 & 0.0 & 10.0 & 0.0 & 1.7 & 1.2 \\
\hline Total Plant Cover & $\mathbf{3 . 3}$ & $\mathbf{1 5 . 0}$ & $\mathbf{1 6 . 7}$ & $\mathbf{1 6 . 7}$ & $\mathbf{2 0 . 0}$ & $\mathbf{2 0 . 0}$ & $\mathbf{1 2 . 5}$ & $\mathbf{8 . 8}$ \\
\hline Bare Ground & 85.0 & 78.3 & 80.0 & 80.0 & 75.0 & 76.7 & 75.0 & -- \\
\hline Litter & 11.7 & 6.7 & 3.3 & 3.3 & 5.0 & 3.3 & 12.5 & -- \\
\hline
\end{tabular}

\subsubsection{Plant Density}

There was a decline in the density of all plants from 2005 to 2006. The decline in shrub density can be attributed to declines in the density of rubber rabbitbrush and Douglas' rabbitbrush, the two most abundant species on the site, and Nevada jointfir. The density of squirretail and Indian ricegrass, two common grasses, also declined. There was a slight increase in the number of galleta plants. The high densities recorded in 2005 are a result of high precipitation. The density estimates recorded in 2006 are similar to those made prior to 2005.

There were some signs of rabbit scat on the cover, but there was no evidence of excessive browsing on the shrubs. There were no signs of erosion on the cover. 
TABle 20. Plant Density (PLANTS PER $\mathrm{M}^{2}$ ) ON CAU 426, Cover

\begin{tabular}{|c|c|c|c|c|c|c|c|c|c|}
\hline & & 2000 & 2002 & 2003 & 2004 & 2005 & 2006 & Reference & Standard \\
\hline \multirow{8}{*}{ Shrubs } & Black Sagebrush & 0.0 & 0.0 & 0.0 & 0.0 & 0.0 & 0.0 & 0.8 & -- \\
\hline & Bud Sagebrush & 0.0 & 0.0 & 0.0 & 0.0 & 0.0 & 0.0 & 0.4 & -- \\
\hline & Fourwing Saltbush & 0.0 & 0.0 & 0.0 & 0.0 & 0.0 & 0.0 & 0.0 & -- \\
\hline & Shadscale & 0.0 & 0.0 & 0.0 & 0.0 & 0.0 & 0.0 & 0.3 & -- \\
\hline & Nevada Jointfir & 0.1 & 0.1 & 0.1 & 0.1 & 0.3 & 0.2 & 0.0 & -- \\
\hline & Douglas' Rabbitbrush & 1.0 & 1.3 & 1.3 & 1.5 & 1.3 & 1.0 & 0.0 & -- \\
\hline & Rubber Rabbitbrush & 0.1 & 1.1 & 0.5 & 0.9 & 1.5 & 0.8 & 0.0 & -- \\
\hline & Winterfat & 0.1 & 0.0 & 0.0 & 0.0 & 0.0 & 0.0 & 0.0 & -- \\
\hline \multicolumn{2}{|r|}{ Total Shrubs } & 1.3 & 2.5 & 1.9 & 2.5 & 3.1 & 2.0 & 1.5 & 1.0 \\
\hline \multirow{3}{*}{ Grasses } & Squirreltail & 1.0 & 0.2 & 0.3 & 0.3 & 1.0 & 0.7 & 0.1 & -- \\
\hline & Galleta & 1.4 & 0.7 & 0.4 & 0.0 & 0.3 & 0.4 & 3.0 & -- \\
\hline & Indian Ricegrass & 1.3 & 0.7 & 0.6 & 0.7 & 2.0 & 1.4 & 0.1 & -- \\
\hline \multicolumn{2}{|r|}{ Total Grasses } & 3.7 & 1.6 & 1.3 & 1.0 & 3.3 & 2.5 & 3.2 & 2.7 \\
\hline \multicolumn{2}{|c|}{ Total Forbs/Annuals } & 0.1 & 1.1 & 0.3 & $\mathbf{0 . 0}$ & 2.9 & 0.6 & 1.6 & 1.1 \\
\hline \multicolumn{2}{|c|}{ Total Plant Density } & 5.1 & 5.2 & 3.5 & 3.5 & 9.3 & 5.1 & 6.3 & 4.8 \\
\hline \multicolumn{2}{|r|}{ Wildlife Use } & -- & Burrows & Burrows & Burrows & Burrows & Burrows & -- & -- \\
\hline \multicolumn{2}{|c|}{ Erosion Classification } & -- & Stable & Stable & Stable & Stable & Stable & -- & -- \\
\hline
\end{tabular}

Note: Scientific names of plants are listed in Appendix F-1.

Note: Erosion Classification Chart included in Appendix F-2.

\subsubsection{Plant Diversity}

There was a slight decrease in the diversity of shrubs and forbs from 2005 to 2006 and a slight increase in the diversity of grasses from 2005 to 2006. Overall diversity has remained approximately stable since 2000 .

Table 21. Diversity of Perennial Plant Species on CAU 426, Cover

\begin{tabular}{|c|c|c|c|c|c|c|c||}
\hline & $\mathbf{2 0 0 0}$ & $\mathbf{2 0 0 2}$ & $\mathbf{2 0 0 3}$ & $\mathbf{2 0 0 4}$ & $\mathbf{2 0 0 5}$ & $\mathbf{2 0 0 6}$ & Reference \\
\hline \hline Shrubs & 0.9 & 1.5 & 1.1 & 1.4 & 1.6 & 1.4 & 0.9 \\
\hline Grasses & 1.1 & 0.6 & 0.5 & 0.3 & 0.7 & 0.8 & 0.7 \\
\hline Forbs/Annuals & 0.1 & 0.7 & 0.2 & 0.0 & 1.1 & 0.5 & 0.6 \\
\hline $\begin{array}{c}\text { Average Number of Species } \\
\text { per Square Meter }\end{array}$ & 2.1 & 2.8 & 1.9 & 1.7 & 3.3 & 2.7 & 2.1 \\
\hline \hline
\end{tabular}




\subsubsection{Summary}

Shrub cover and density in 2006 exceed the standards for revegetation success. Shrub cover was more than twice the revegetation standard. Shrub density was also twice the standard. Grass density, however, was slightly below the standard. Overall, the vegetation on the CAU 426 cover is well established. Shrubs are vigorous and healthy. Grass cover and density has varied over the years, but there are still more grasses on the cover than on the surrounding areas.

In the event the fence around this site is removed, there are several issues to consider. The proximity of this site to grazing animals such as horses and antelope is evident due to the area around the site having very few grasses. The grasses on the cover may attract the horses visiting the nearby water source, and the abundance and vigor of the grasses may be impacted. Another issue is halogeton, a noxious weed. If the site becomes a gathering point or trail for grazing animals, the soil may be disturbed and favor the growth and dominance of halogeton, possibly to levels attained before the site was revegetated. In the event the fence is removed, periodic monitoring of the site is recommended to determine the effect of grazing animals. Such information would be valuable for future revegetation efforts in the region. 


\section{CAU 426, Cactus Spring Waste Trenches, COVER, Photographic REFERENCE}

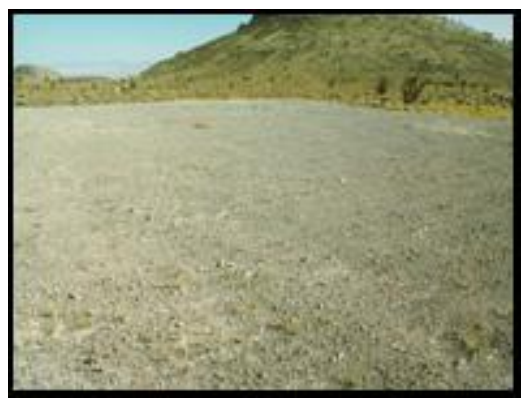

JUNE 1998

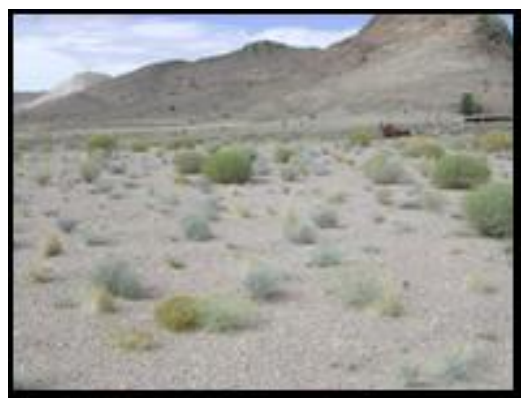

SEPTEMBER 2003

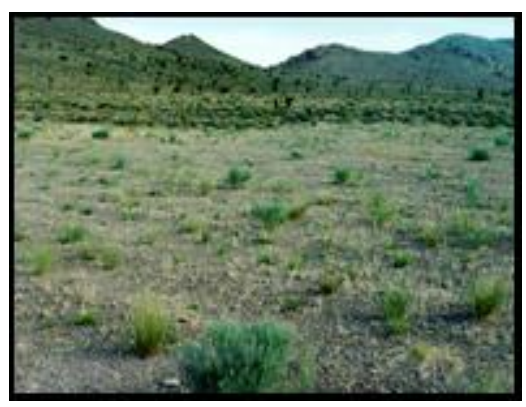

JUNE 2000

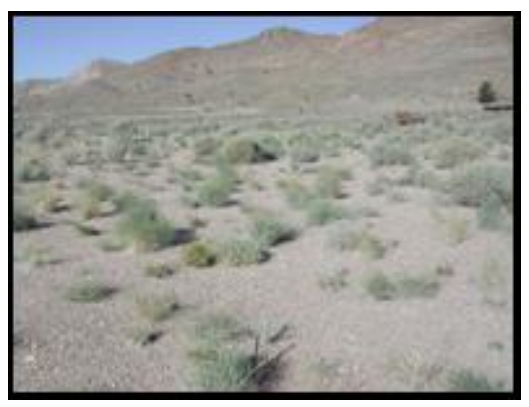

JUNE 2004

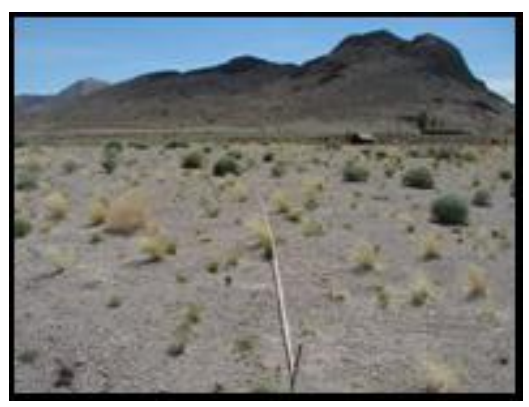

JUNE 2002

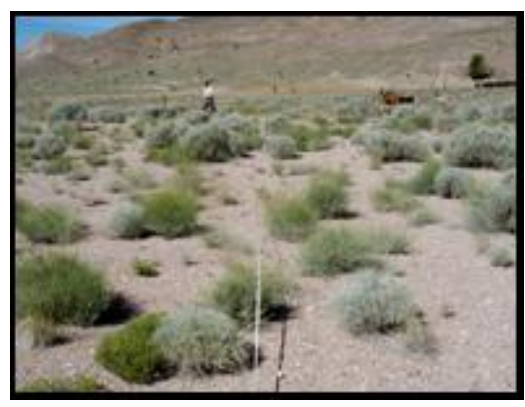

JUNE 2005

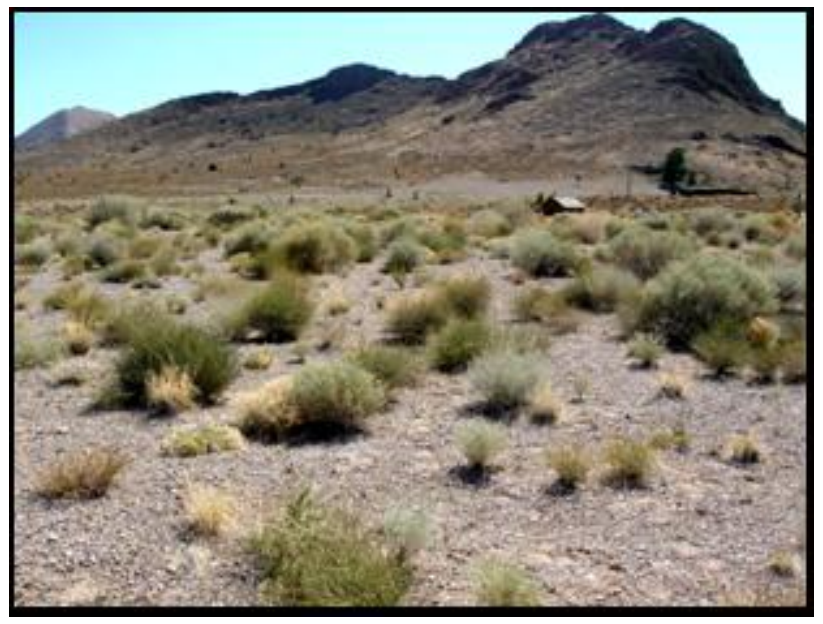

JUNE 2006 
Post-Closure Inspection Report - TTR

Revision: 0

Date: June 2007

THIS PAGE INTENTIONALLY LEFT BLANK 


\section{APPENDIX F-1}

\section{Common and scientific names of plant species encountered at TTR or included in original seed mix}

\begin{tabular}{|c|c|c|}
\hline & $\underline{\text { Scientific Name }}$ & Common Name \\
\hline \multirow[t]{14}{*}{ Shrubs } & $\overline{\text { Artemisia nova }}$ & Black sagebrush \\
\hline & Artemisia spinescens & Bud sagebrush \\
\hline & Atriplex canescens & Fourwing saltbush \\
\hline & Atriplex confertifolia & Shadscale saltbush \\
\hline & Chrysothamnus greenei & Greene’s rabbitbrush \\
\hline & Chrysothamnus viscidiflorus & Low rabbitbrush \\
\hline & Ephedra nevadensis & Nevada jointfir \\
\hline & Ericameria nauseosa & Rubber rabbitbrush \\
\hline & Gutierrezia sarothrae & Broom snakeweed \\
\hline & Hymenoclea salsola & White burrobrush \\
\hline & Krascheninnikovia lanata & Winterfat \\
\hline & Menodora spinescens & Spiny menodora \\
\hline & Opuntia pulchella & Sand cholla \\
\hline & Sarcobatus vermiculatus & Black greasewood \\
\hline \multirow[t]{7}{*}{ Grasses } & Achnatherum hymenoides & Indian ricegrass \\
\hline & Elymus elymoides & Bottlebrush squirreltai \\
\hline & Bromus tectorum & Cheatgrass \\
\hline & Dasyochloa pullchella & Low woollygrass \\
\hline & Pleuraphus jamesii & Galleta grass \\
\hline & Sporobolus airoides & Alkali sacatoon \\
\hline & Sporobolus cryptandrus & Sand dropseed \\
\hline \multirow[t]{17}{*}{ Forbs/Annuals } & Ambrosia species & Ragweed \\
\hline & Astragalus lentiginosa var. fremontii & Fremont's milkvetch \\
\hline & Astragalus species & Milkvetch \\
\hline & Camissonia boothii & Booth’s suncup \\
\hline & Camissonia species & Suncup \\
\hline & Chaneactis xantiana & Xantus pincushion \\
\hline & Chenactis steviodes & Steve's pincushion \\
\hline & Chenopodium album & Lambsquaarters \\
\hline & Cryptantha circumscissa & Cushion cryptantha \\
\hline & Cryptantha micrantha & Red root cyrptantha \\
\hline & Cryptantha species & Cryptantha \\
\hline & Cymopterus species & Springparsley \\
\hline & Descurania pinnata & Pinnate tansymustard \\
\hline & Eriastrum eremicum & Desert woolstar \\
\hline & Eriastrum sparsiflorum & Fewflower woolstar \\
\hline & Eriogonum deflexum & Flatcrown buckwheat \\
\hline & Eriogonum nidularium & Birdnest buckwheat \\
\hline
\end{tabular}


Scientific Name

Forbs/Annuals Eriogonum species

(continued) Erodium cicutarium

Gilia nyensis

Gilia species

Halogeton glomeratus

Ipomopsis polycladon

Lepedium flavum

Lepedium lasiocarpum

Lepedium montanum

Lepedium species

Lupinus species

Macheranthera canescens

Mentzelia albomarginatus

Mirabilus biglovei

Oenothera species

Phacelia crenulata

Phacelia species

Salsola tragus

Sphaeralcea ambigua

Stephanomeria exigua

Tiquilia plicatas
Common Name

Buckwheat

Filaree

Nye gilia

Gilia

Halogeton

Manybranched gilia

Yellow pepperweed

Shaggyfruit pepperweed

Mountain pepperweed

Pepperweed

Lupine

Hoary macharanthra

White blazingstar

Bigelow's four-o'clock

Eveningprimrose

Cleftleaf wildheliotrope

Phacelia

Prickly Russian thistle

Desert globemallow

Small wirelettuce

Fanleaf tiquilia 


\section{APPENDIX F-2}

\begin{tabular}{|c|c|c|c|c|c|c|c|}
\hline \multicolumn{8}{|c|}{ Erosion Condition Classification } \\
\hline \multicolumn{2}{|r|}{ Surface Litter } & \multicolumn{2}{|r|}{ Pedestalling } & \multicolumn{2}{|r|}{ Rills <9" } & \multicolumn{2}{|r|}{ Rills >9" } \\
\hline 1 & $\begin{array}{l}\text { Accumulating in } \\
\text { Place }\end{array}$ & 1 & $\begin{array}{l}\text { No Visual } \\
\text { Evidence }\end{array}$ & 1 & $\begin{array}{l}\text { No Visual } \\
\text { Evidence }\end{array}$ & 1 & $\begin{array}{l}\text { No Visual } \\
\text { Evidence }\end{array}$ \\
\hline 2 & $\begin{array}{l}\text { Slight } \\
\text { Movement }\end{array}$ & 2 & Slight Pedestalling & 2 & $\begin{array}{l}\text { Rills at Intervals } \\
>10 \text {, }\end{array}$ & 2 & $\begin{array}{l}\text { Rills at Intervals } \\
>10\end{array}$ \\
\hline 3 & $\begin{array}{l}\text { Moderate } \\
\text { Movement }\end{array}$ & 3 & $\begin{array}{l}\text { Small Rock and } \\
\text { Plant Pedestalling }\end{array}$ & 3 & $\begin{array}{l}\text { Rills at } 10 \\
\text { Intervals }\end{array}$ & 3 & $\begin{array}{l}\text { Rills at } 10^{\prime} \\
\text { Intervals }\end{array}$ \\
\hline 4 & $\begin{array}{l}\text { Extreme } \\
\text { Movement }\end{array}$ & 4 & $\begin{array}{l}\text { Pedestalling } \\
\text { Plants; Roots } \\
\text { Exposed }\end{array}$ & 4 & $\begin{array}{l}\text { Rills at } 5-10 \\
\text { Intervals }\end{array}$ & 4 & $\begin{array}{l}\text { Rills at } 5-10^{\prime} \\
\text { Intervals }\end{array}$ \\
\hline 5 & $\begin{array}{l}\text { Very Little } \\
\text { Remaining Litter }\end{array}$ & 5 & $\begin{array}{l}\text { Most Plants and } \\
\text { Rocks Pedestalled; } \\
\text { Roots Exposed }\end{array}$ & 5 & $\begin{array}{l}\text { Rills at Intervals } \\
<5 \text {, }\end{array}$ & 5 & $\begin{array}{l}\text { Rills at Intervals } \\
<5 \text {, }\end{array}$ \\
\hline \multicolumn{2}{|r|}{ Rating: __ } & \multicolumn{2}{|r|}{ Rating:___ } & \multicolumn{2}{|r|}{ Rating: ___ } & \multicolumn{2}{|r|}{ Rating: ___ } \\
\hline & & & & & & & Total: \\
\hline
\end{tabular}

\begin{tabular}{|c|c|}
\hline Numerical Rating Total & Erosion Condition Class \\
\hline 0.0 to 4.0 & Stable \\
\hline 4.1 to 8.0 & Slight \\
\hline 8.1 to 12.0 & Moderate \\
\hline 12.1 to 16.0 & Critical \\
\hline 16.1 to 20.0 & Severe \\
\hline
\end{tabular}


Post-Closure Inspection Report - TTR

Revision: 0

Date: June 2007

THIS PAGE INTENTIONALLY LEFT BLANK 
Post-Closure Inspection Report - TTR

Revision: 0

Date: June 2007

\section{LIBRARY DISTRIBUTION LIST}


Post-Closure Inspection Report - TTR

Revision: 0

Date: June 2007

THIS PAGE INTENTIONALLY LEFT BLANK 


\section{LIBRARY DISTRIBUTION LIST}

U.S. Department of Energy

National Nuclear Security Administration

Nevada Site Office

Technical Library

P.O. Box 98518, M/S 505

Las Vegas, NV 89193-8518

U.S. Department of Energy

Office of Scientific and Technical Information

P.O. Box 62

Oak Ridge, TN 37831-0062

Southern Nevada Public Reading Facility

c/o Nuclear Testing Archive

P.O. Box 98521, M/S 400

Las Vegas, NV 89193-8521

Manager, Northern Nevada FFACO

Public Reading Facility

c/o Nevada State Library \& Archives

Carson City, NV 89701-4285
1 (Uncontrolled, electronic copy)

1 (Uncontrolled, electronic copy)

2 (Uncontrolled, electronic copies)

1 (Uncontrolled, electronic copy) 
Post-Closure Inspection Report - TTR

Revision: 0

Date: June 2007

THIS PAGE INTENTIONALLY LEFT BLANK 